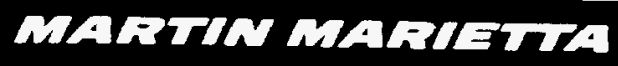

ENVIRONMENTAL

RESTORATION

PROGRAM

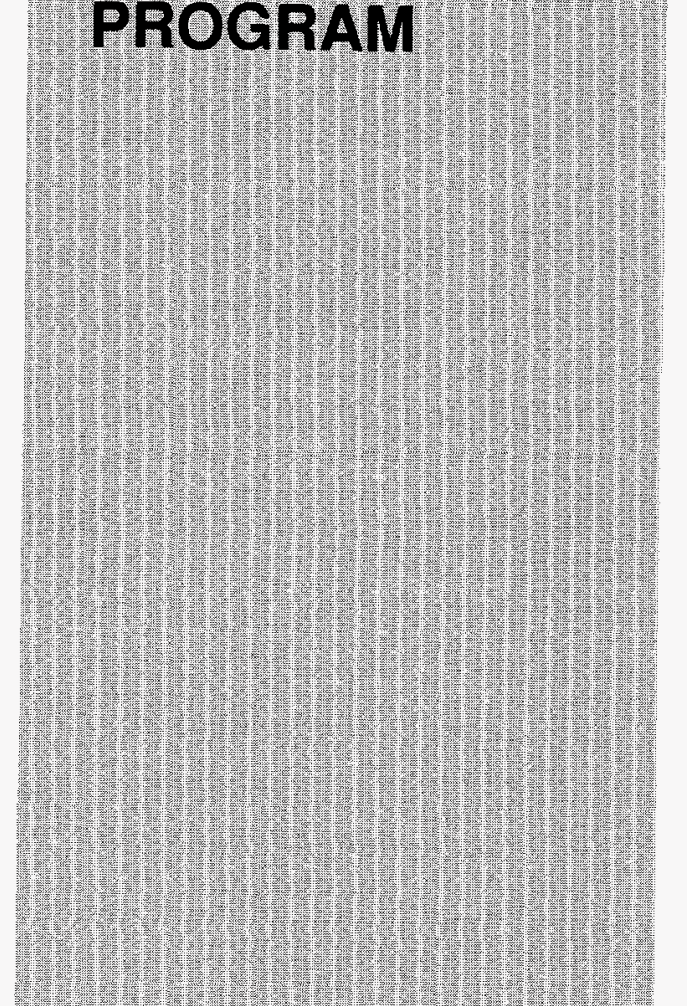

(1)

This report was prepared as an account of work sponsored by an agency of the United States
Government. Neither the United States Government nor any agency thereof, nor any of their employees, makes any warranty, express or implied, or assumes any legal liability or responsibility for the accuracy, completeness, or usefulness of any information, apparatus, product, or process disclosed, or represents that its use would not infringe privately owned rights. Reference herein to any specific commercial product, process, or service by trade name, trademark, manufacturer, or otherwise does not necessarily constitute or imply its endorsement, recommendation, or favoring by the United States Government or any agency thereof. The views and opinions of authors expressed herein do not necessarily state or reflect those of the United States Government or any agency thereof. 
Ogden Environmental and Energy Services Co., Inc.

contributed to the preparation of this document and should not be considered an eligible contractor for its review.

This report has been reproduced directly from the best available copy.

Available to DOE and DOE contractors from the Office of Scientific and Technical Information, P.O. Box 62, Oak Ridge, TN 37831; prices available from $615-576-8401$.

Available to the public from the National Technical Information Service, U.S. Department of Commerce, 5285 Port Royal Rd., Springfield, VA 22161. 


\section{DISCLAIMER}

Portions of this document may be illegible in electronic image products. Images are produced from the best available original document. 
Environmental Restoration Division

ORNL Environmental Restoration Program

\title{
Groundwater Quality Monitoring Well Installation for Waste Area Grouping 3 at Oak Ridge National Laboratory, Oak Ridge, Tennessee
}

\author{
J. A. Mortimore \\ M. L. Ebers
}

Date Issued-September 1994

Prepared for

U.S. Department of Energy

Office of Environmental Restoration and Waste Management under budget and reporting code EW 20

Environmental Restoration and Waste Management Programs

Oak Ridge National Laboratory

Oak Ridge, Tennessee 37831-6285

managed by

MARTIN MARIETTA ENERGY SYSTEMS, INC.

for the

U.S. DEPARTMENT OF ENERGY

under contract DE-AC05-84OR21400

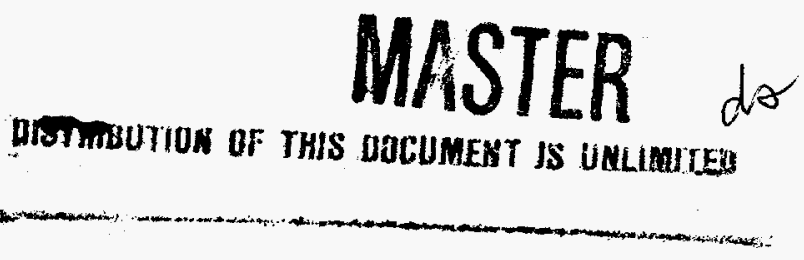




\section{Author Affiliations}

J. A Mortimore is staff project manager with the Environmental Restoration Program, Oak Ridge National Laboratory, Martin Marietta Energy Systems, Incorporated. M. L. Ebers is a senior hydrogeologist with Ogden Environmental and Energy Services Co., Inc. (formally ERC Environmental and Energy Services Company). 


\section{CONTENTS}

EXECUTIVE SUMMARY $\ldots \ldots \ldots \ldots \ldots \ldots \ldots \ldots \ldots \ldots \ldots \ldots, \mathrm{v}$

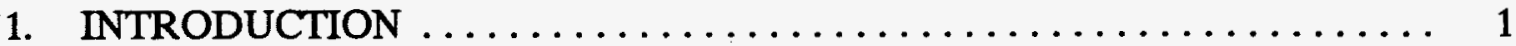

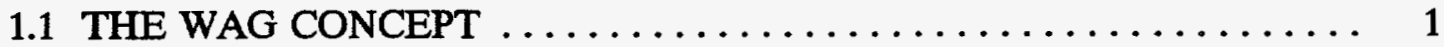

1.2 DESCRIPTION OF WAG $3 \ldots \ldots \ldots \ldots \ldots \ldots \ldots \ldots \ldots \ldots \ldots$

2. INSTALLATION METHODS $\ldots \ldots \ldots \ldots \ldots \ldots \ldots \ldots \ldots \ldots \ldots \ldots \ldots$

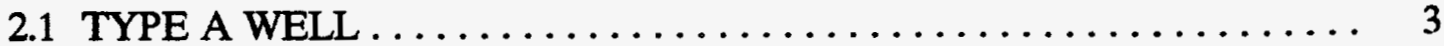

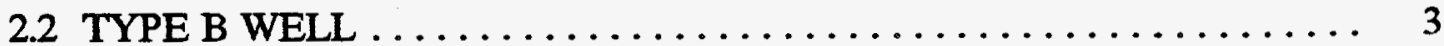

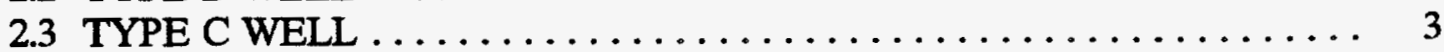

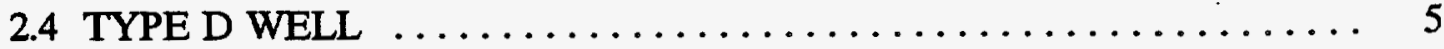

3. ENVIRONMENTAL, HEALTH, AND SAFETY REQUIREMENTS $\ldots \ldots .6$

4. FIELD SUPPORT $\ldots \ldots \ldots \ldots \ldots \ldots \ldots \ldots \ldots \ldots \ldots \ldots \ldots \ldots \ldots$

5. DRILLING RECORDS $\ldots \ldots \ldots \ldots \ldots \ldots \ldots \ldots \ldots \ldots \ldots \ldots \ldots$

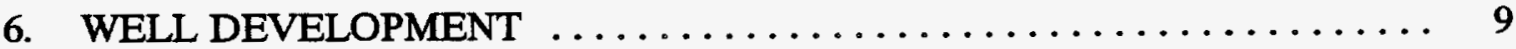

7. SAMPLING DURING INSTALLATION $\ldots \ldots \ldots \ldots \ldots \ldots \ldots \ldots \ldots$

8. SPECIAL NOTES ON INSTALLATION AND DEVELOPMENT $\ldots \ldots \ldots \ldots$

8.1 CONTAMINATION DETECTED $\ldots \ldots \ldots \ldots \ldots \ldots \ldots \ldots \ldots \ldots$

8.2 DEVIATIONS FROM THE SPECIFICATIONS $\ldots \ldots \ldots \ldots \ldots \ldots \ldots 11$

8.3 HYDRAULIC FLUID LEAKS $\ldots \ldots \ldots \ldots \ldots \ldots \ldots \ldots \ldots \ldots \ldots$

REFERENCES $\ldots \ldots \ldots \ldots \ldots \ldots \ldots \ldots \ldots \ldots \ldots \ldots \ldots \ldots \ldots \ldots \ldots \ldots$

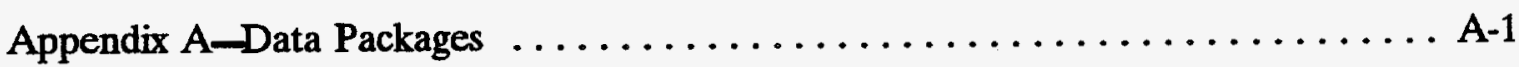

Appendix B-Operating Instructions for Handling Water and Cuttings from Well Drilling and Development of Groundwater Quality Monitoring Wells 


\section{EXECUTTVE SUMMARY}

This report documents the drilling and installation of 15 groundwater quality monitoring (GQM) wells on the perimeter of Waste Area Grouping (WAG) 3. WAG 3 is located in Melton Valley, approximately $3000 \mathrm{ft}$ west of the west gate of Oak Ridge National Laboratory, and consists of an estimated 22 acres. The subject site contains three solid waste management units: the Contractors' Landfill, the Closed Scrap Metal Area, and Solid Waste Storage Area 3. The wells at WAG 3 were drilled and developed between September 1987 and August 1990. These wells were installed to characterize and assess the WAG in accordance with applicable Department of Energy, state, and Environmental Protection Agency regulatory requirements.

Well design and placement were performed by Martin Marietta Energy Systems, Inc. (Energy Systems) geologic staff and their subcontractors. The wells were drilled, installed, and developed by two drilling subcontractors (A. L. Clark Drilling Services and Geotek Engineering, Inc.) under contract with Energy Systems. The contract was administered by the Energy Systems Engineering Division for the Environmental Restoration (ER) Program. Hydrogeologic support was provided by an environmental subcontractor [ERC Environmental and Energy Services, Inc. (ERCE)] under contract with Energy Systems. (As of January 1, 1992, ERCE started operating under the name of Ogden Environmental and Energy Services Co., Inc.) This contract was administered by ER Division staff. Radiation protection and industrial hygiene support for the drilling program were provided by Energy Systems staff or their subcontractors.

The wells at WAG 3 were drilled with auger or air rotary rigs. Depending upon the hydrogeologic conditions present at each proposed well location, one of four basic installation methods was utilized. Detailed procedures for well construction were specified by the Engineering Division to ensure that the wells would provide water samples representative of the aquifer. To ensure conformance with the specifications, Energy Systems Construction Engineering and ERCE provided continuous oversight of field activities.

The purpose of the well installation program was to install GQM wells for groundwater characterization at WAG 3. Data packages produced during installation activities by the ERCE hydrogeologists are an important product of the program. These packages document the well drilling, installation, and development activities and provide valuable data for well sampling and WAG characterization. The forms contained in the packages include predrilling and postdrilling checklists, drilling and construction logs, development and hydraulic conductivity records, and quality control-related documents. 


\section{INTRODUCTION}

The purpose of this report is to document the drilling and installation of the groundwater quality monitoring (GQM) wells on the perimeter of Waste Area Grouping (WAG) 3 . Installation of GQM wells was required at Oak Ridge National Laboratory (ORNL) for regulatory compliance. Data obtained from these wells will be used to characterize and assess groundwater quality at the perimeter of each WAG in accordance with applicable Department of Energy, state, and Environmental Protection Agency regulatory requirements. The first eight wells installed in WAG 3 were drilled by A.L. Clark Drilling Services from September 1987 to January 1988. Five additional wells were drilled by Geotek Engineering Company in November 1989. These 13 wells were developed from April to May 1990. Two additional monitoring wells were drilled by Geotek in May 1990 and developed in August 1990.

\subsection{THE WAG CONCEPT}

At ORNL, the solid waste management units (SWMUs) include solid waste storage areas (SWSAs), pipelines, spill sites, buildings, ponds, and experimental test sites that are considered to be potential sources of contamination. The SWMUs are further grouped into WAGs, the boundaries of which are defined by watersheds that contain contaminants derived from similar assemblages of operating facilities and SWMUs. Basically, the wells are located on or near these boundaries to determine whether contaminants have been released from the WAGs.

\subsection{DESCRIPTION OF WAG 3}

WAG 3 is located in Melton Valley, approximately $3000 \mathrm{ft}$ west of the west gate of ORNL, and consists of an estimated 22 acres [Fig. 1, map pocket (MMES map \#C3E20004A082, Rev. C)]. The subject site contains three SWMUs, the Contractors' Landfill, the Closed Scrap Metal Area, and SWSA 3. Fifteen monitoring wells were drilled around the perimeter of WAG 3 (Fig. 1, map pocket).

The Contractor's Landfill is located about $130 \mathrm{ft}$ west of SWSA 3 and consists of about 7 acres. This SWMU has been in operation since 1975 and continues to be used for the disposal of construction debris.

The Closed Scrap Metal Area consists of approximately 4 acres of graded fill maintained in grass. Its general location is southeast of SWSA 3, although its exact boundaries are not known. This SWMU opened in the early 1950s as a contractors' landfill and was operated as such for an estimated 15 years; then the fill area was reportedly used for storage of scrap metal. SWSA 3 consists of approximately 7 acres; it appears in plan view as two offset rectangles with a triangular protrusion on the southeastern side. This SWMU is located northeast of the Closed Scrap Metal Area and is currently planted in grass and enclosed by 
2

a chain-link fence. SWSA 3 was used for the disposal of contaminated trash and laboratory equipment and was operational from 1946 to 1951. 


\section{INSTALLATION METHODS}

Four basic types of well construction were used during the GQM installation program at ORNL. Schematic diagrams of these four well types are shown on Fig. 2. These four types (A, B, C, and D) were all used at WAG 3, and they are described in Sects. 4.1 through 4.4. The specific details of each well installation are included in the monitoring well narratives (Appendix A). The specifications for drilling and well installation were provided in Construction Specifications for Monitoring Wells Installation Construction Project, K-4491GG1. ${ }^{1}$ The proposed well design criteria for the WAG 3 wells can be found in the report Preliminary Geohydrologic Site Characterization and Proposed Water Quality Well Locations for $W A G 4,5,3$, and SWSA 1, ORNL/RAP/Sub-86/72139/1.2 Actual completion data for WAG 3 are listed in Table 1.

\subsection{TYPE A WELL}

The type A well boring is drilled to total depth with solid-stem augers. On completion, the boring is bailed with a steel bailer to remove drill cuttings. The well is completed with 2in.-diam stainless steel screen, casing, and a silt trap. Stainless steel centralizers are positioned at the top of the screen and every $20 \mathrm{ft}$ along the casing. A sandpack is poured into the annular space from total depth to $1 \mathrm{ft}$ above the screen. Pelleted bentonite is poured into the annular space to create a 2 - $\mathrm{ft}$ seal above the sandpack. The top of the bentonite seal is measured with a stainless steel weighted tape. The annular space above the bentonite seal is then grouted to the surface through a tremie pipe.

\section{TYPE B WELL}

The first step in drilling the type B well is to auger a boring from the surface to a depth of $4 \mathrm{ft}$. A steel diverter casing is installed, and the annulus is grouted to the surface. The boring is then deepened with a tricone air rotary bit to a minimum depth of $10 \mathrm{ft}$ total and $2 \mathrm{ft}$ into bedrock. Next, a steel surface casing is installed and grouted into place. The air rotary method is used to drill the boring to the required depth. The well is completed with 4-in.-diam stainless steel screen and casing. A sandpack, a bentonite seal, and grout are installed in the annular space by the same procedures as used for the type $A$ well.

\subsection{TYPE C WELL}

A 14-in.-diam boring is augered, and a 10-in.-diam steel casing is set in the same manner as in type B wells. The boring is deepened with an 8-in.-diam tricone air rotary bit to a predetermined depth. Four-in.-diam open-ended stainless steel casing is set from the drilled depth to the surface and grouted into place with a tremie pipe. Below the casing, an open-hole interval is drilled with a 3-7/8-in.-diam tricone air rotary bit. This section of the boring is left open to serve as the sample interval. 


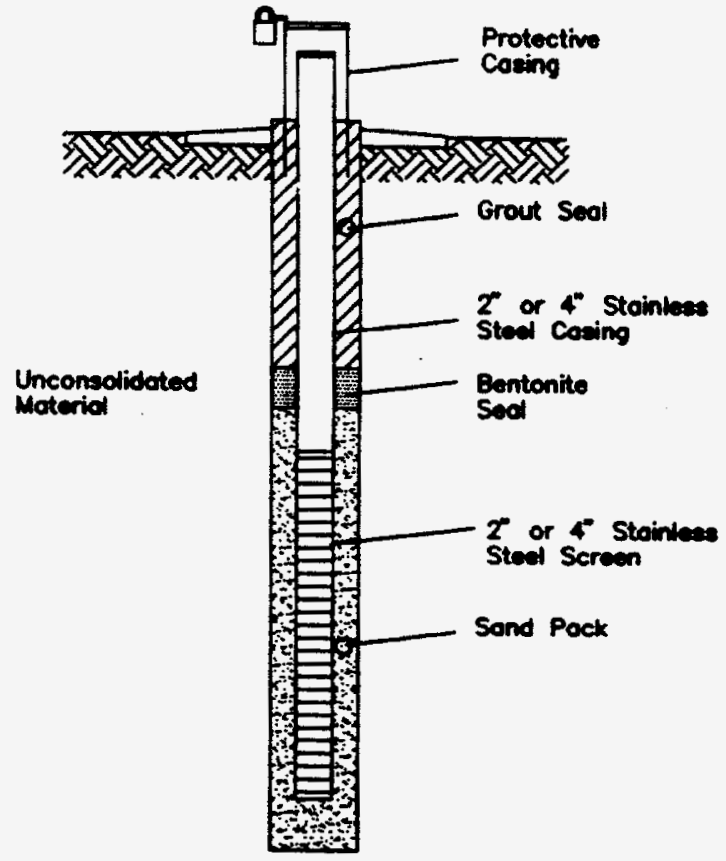

TMPE A WELL

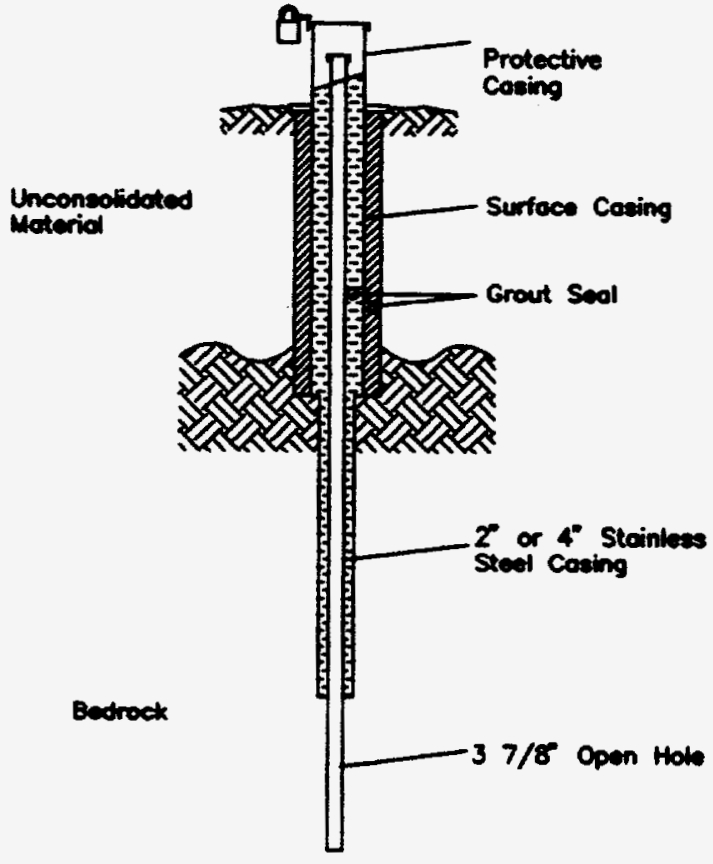

TYPE C WELL

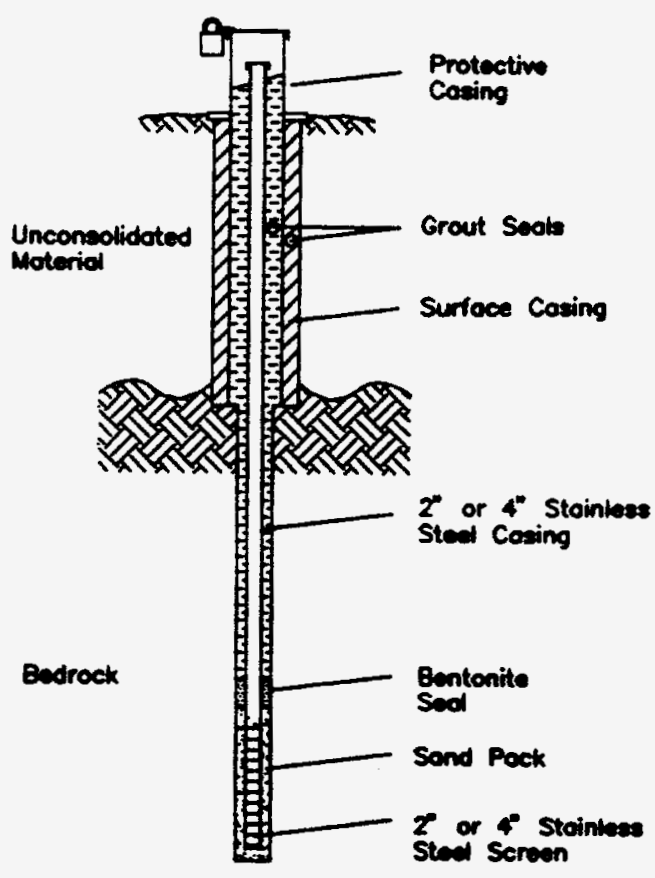

TYPE B MELL

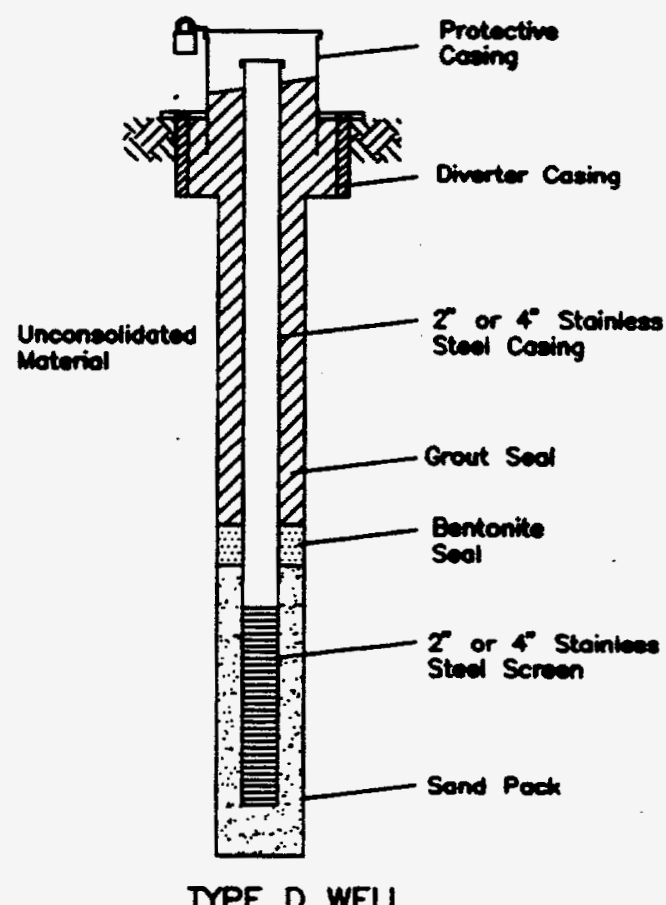

TYPE D WELL

Fig. 2. The four types of well construction used during the Groundwater Quality Monitoring Well Installation Program at Oak Ridge National Laboratory. 


\subsection{TYPE D WELL}

A type $\mathrm{D}$ well is a type $\mathrm{A}$ well with a diverter casing. If the auger encounters refusal before reaching total depth on a type A well, the boring is reamed with a larger auger to refusal and a steel diverter casing is installed. The annulus is grouted up to surface level. The boring is deepened with a tricone air rotary bit to total depth, and the well is completed with 2-in.-diam stainless steel screen and casing. A sandpack, a bentonite seal, and grout are installed in the annular space by the same procedures as those used for the type A well.

Table 1. Actual completion data for WAG 3

\begin{tabular}{cccccc}
\hline Well & $\begin{array}{c}\text { Depth } \\
\text { clean to } \\
(\mathrm{ft})^{\mathrm{a}}\end{array}$ & $\begin{array}{c}\text { SST casing } \\
\text { diam (in.) }\end{array}$ & $\begin{array}{c}\text { Well } \\
\text { type }\end{array}$ & $\begin{array}{c}\text { Screened } \\
\text { interval (ft) }\end{array}$ & $\begin{array}{c}\text { Water } \\
\text { level } \\
(\mathrm{ft})^{\mathrm{b}}\end{array}$ \\
\hline 985 & 35.0 & 2 & D & $20.0-35.0$ & -6.9 \\
986 & 62.0 & 4 & B & $41.1-61.7$ & -9.2 \\
987 & 48.2 & 4 & B & $27.1-47.9$ & -23.5 \\
988 & 46.0 & 2 & D & $30.8-45.8$ & -23.6 \\
990 & 40.8 & 4 & B & $25.5-40.5$ & -29.0 \\
991 & 85.0 & 4 & B & $70.0-85.0$ & -45.6 \\
992 & 52.0 & 2 & A & $33.0-48.0$ & -36.0 \\
993 & 45.0 & 4 & B & $23.9-44.7$ & -21.6 \\
994 & 80.5 & 4 & C & $59.1-80.5$ & -22.0 \\
995 & 47.84 & 2 & D & $32.84-47.84$ & -21.5 \\
996 & 61.76 & 4 & B & $41.13-61.49$ & -14.6 \\
997 & 33.0 & 2 & D & $13.82-29.68$ & -6.5 \\
998 & 20.0 & 2 & A & $4.7-19.7$ & +0.2 \\
1247 & 22.7 & 2 & D & $7.5-22.5$ & -18.2 \\
1248 & 72.5 & 4 & B & $52.3-72.3$ & -34.2 \\
\hline
\end{tabular}

Total drilled depth may vary from clean-out depth. See data packages (Appendix A).

'Predevelopment water level; depth measured from ground surface. (Negative is below surface; positive, above surface.) 


\section{ENVIRONMENTAL, HEALTH, AND SAFETY REQUIREMENTS}

All well drilling at WAG 3 was conducted in accordance with procedures outlined in Health, Safety, and Environmental Protection Procedures for Excavating Operations, ORNL/M$116 / \mathrm{R1}^{3}$. Among the procedures set forth by this document is a system for rating proposed well locations according to the degree of probability that contamination will be encountered. This rating determined the level of personnel training required and health and safety coverage to be used during drilling.

The Superfund Amendment Reauthorization Act required still more stringent health and safety measures for personnel working in waste areas. These workers were required to have $40 \mathrm{~h}$ of training for hazardous duty through an ORNL-approved course, $8 \mathrm{~h}$ of refresher training each year, $8 \mathrm{~h}$ of supervisor's training for field supervisors, a whole-body count, baseline urinalysis, respirator testing and fitting, and medical monitoring. Personnel were also required to take a construction-worker training course covering the fundamentals of radioactivity and other types of contamination as well as the other hazards that could be encountered at ORNL. The workers were taught the proper procedures to follow in the event of an on-site emergency.

Special procedures were used during drilling. The ground surface at all drill sites was covered with polyethylene sheeting to prevent contact between the tools and the ground. The sheeting would also have protected the environment in the event of a hydraulic fluid release. Containment was required for all drill cuttings produced. During augering, a metal pan was used to hold cuttings until a health physicist (HP) could determine their proper disposition. During air rotary drilling, cuttings were diverted from the borehole to a special containment box designed by Martin Marietta Energy Systems, Inc. (Energy Systems). The box is a 500-gal, trailer-mounted tank with demister elements and high-efficiency particulate air filters at the air exhaust. In order that appropriate methods of disposal could be determined, the tank contents were checked by the HP for radioactive contamination and by the site hydrogeologist for volatile organics. The operating instructions that were followed for determining disposition of the cuttings and water produced during drilling and development are included in Appendix B. 


\section{FIELD SUPPORT}

The construction contractor Geotek Engineering Company, whose contract began in May 1989, installed the GQM wells in WAG 3 during the period from September 1987 to August 1990. ORNL Engineering administered the drilling contract through Energy Systems Procurement. The management organization chart for the project can be found in the report Task Management Plan for Groundwater Quality Monitoring Well Installation, ORNL/RAP/LTR-88/28.

The hydrogeologic support and installation record keeping were supplied through a contract with ERC Environmental and Energy Services Company (ERCE), formerly $\mathrm{EDGe} / \mathrm{MCI}$. An ERCE representative was present during all activities that affected the quality of the wells and advised Energy Systems on well construction. ORNL personnel or their subcontractors provided HP and industrial hygiene support.

Construction engineering support was supplied by Energy Systems personnel. Drawings, excavation permits, well placement in the field, and as-built surveying and calculations were done by the Energy Systems Civil and Architectural Department or by their subcontractor, Adams Craft Herz Walker Engineering Company. The as-built survey coordinates and elevations are on the well installation/completion form for each well (Appendix A). The as-built coordinates are also summarized in a table on the well location map (Fig. 1). 


\section{DRILLING RECORDS}

A complete data package has been compiled for each of the 15 GQM wells drilled in WAG 3. These data packages are presented in numerical order in Appendix A. All original records are retained in the Environmental Restoration (ER) Division Records Control Data Base. The forms included in each well data package are listed here in the order in which they appear in the package:

1. monitor well narrative,

2. predrilling checklist for monitoring wells,

3. decontamination checklist for drilling equipment,

4. well log,

5. well installation/completion form,

6. monitoring well materials certification,

7. post-well completion checklist,

8. monitoring well development form,

9. monitoring well development progress,

10. hydraulic conductivity calculation,

11. nonconformance report (if necessary), and

12. chain of custody forms.

Three additional forms used in the field by the site hydrogeologist but not included in the published data packages are the monitoring well progress form, the hydraulic conductivity test field sheet, and the containment box checklist. These forms are kept in the ER Division Records Control Data Base. 


\section{WELL DEVELOPMENT}

Wells were developed by pumping. Wells with high initial turbidities were surged beforehand with a workover rig and a stainless steel surge block to facilitate removal of the sediment from the wells. The contents of the wells were then pumped out using Geoguard airlift pumps and oilless air compressors. Development of a well was considered complete when at least three well volumes had been removed and the turbidity was measured at 5 NTUs or less. Several wells had turbidity ratings higher than 5 NTUs even after extensive pumping, but, in order to prevent the pulling in of groundwater from too far away, a maximum limit of $\mathbf{3 0}$ to 35 well volumes was determined by Energy Systems hydrogeologists to be the upper limit that should be removed. The contents of the wells were pumped out using Geoguard development pumps. The two-stage Geoguard pumps were converted to dedicated bladder pumps for sampling after development was complete. All development water was contained and disposed of according to the operating instructions in Appendix B.

Of the 15 wells in WAG 3,11 had turbidity ratings of less than or equal to 5 NTUs. The number of well volumes removed ranged from 9.0 to 34.4 , with an average of 22.0 for the 13 monitor wells numbered 985 through 988 and 990 through 998. The remaining two GQM wells, 1247 and 1248 , each yielded less than $10 \mathrm{gal}$ during development. The procedure for measuring turbidity described in ORNL/RAP/LTR-88/28 was replaced with a more accurate method. While the previously used method depended on a visual comparison of the sample with prepared standards, the new method employs the Cole-Parmer turbidimeter, which measures NTUs by passing a lens-focused light beam through a test tube filled with a water sample. A photosensor detects the intensity of the exiting light beam, and an analog scale on the instrument displays the turbidity of the sample. 


\section{SAMPLING DURING INSTALLATION}

The ERCE hydrogeologist took samples of soil, rock, and drilling water during well installation and submitted them to the ORNL Analytical Chemistry Division for chemical analyses. Soil and rock samples were taken from the unsaturated and saturated zones. Samples of drilling water were collected from the water pump discharge on the drill rig during drilling with the air rotary. All samples were transferred using chain-of-custody forms, which are included in the data packages. The sampling procedures are explained in ORNL/RAP/LTR-88/28. ${ }^{4}$ Soil samples were collected from each single well and from one well of each well pair. A drilling-water sample was collected from each air-rotary-drilled boring.

Analyses for 31 chemical elements, gross alpha, gross beta, and ${ }^{40} \mathrm{~K}$ were routinely performed on the soil and water samples. The results from these analyses are contained in the ER Division Records Control Data Base. 


\section{SPECIAL NOTES ON INSTALLATION AND DEVELOPMENT}

The following special events took place during the drilling of the GQM wells in WAG 3.

\subsection{CONTAMINATION DETECTED}

- An alcohol odor was detected during the drilling and completion of well 996.

- A sulfur smell was detected during the development of well 997, but it disappeared after a couple of days.

\subsection{DEVIATIONS FROM THE SPECIFICATIONS}

- Well 988 was drilled to $100 \mathrm{ft}$ and then plugged back to $47.5 \mathrm{ft}$ before the well was completed.

- Well 989 was a dry hole. It was drilled to a total depth of $100 \mathrm{ft}$ and was plugged and abandoned by grouting the borehole from a depth of 100 feet up to the surface.

- Two nonconformities were documented during the installation of well 991 . The first nonconformity was the installation of too many centralizers. The second nonconformity was a bentonite bridge in the annular space at $35 \mathrm{ft}$ and the resulting open zone in the annulus from 35 to $60 \mathrm{ft}$.

\subsection{HYDRAULIC FLUID SPILLS}

A hydraulic hose break occurred at well 995 . No wellbore contamination occurred, and all hydraulic fluid was cleaned from the equipment before drilling continued. 


\section{REFERENCES}

1. Engineering Division, Construction Specifications for Monitoring Wells Installation Construction Project, K-4491G-G1 (Rev. 2), Martin Marietta Energy Systems, Inc., Oak Ridge National Laboratory, Oak Ridge, Tenn., August 1988.

2. MCI Consulting Engineers, Inc., Preliminary Geohydrologic Site Characterization and Proposed Water Quality Well Locations for WAG 4, 5, 3, and SWSA 1, ORNL/RAP/Sub86/72139/1, Martin Marietta Energy Systems, Inc., Oak Ridge National Laboratory, Oak Ridge, Tenn., February 1987.

3. Environmental Compliance and Health Protection Division, Health, Safety, and Environmental Protection Procedures for Excavating Operations, ORNL/M-116/R1, Martin Marietta Energy Systems, Inc., Oak Ridge National Laboratory, Oak Ridge, Tenn., March 3, 1988.

4. J. A. Mortimore, Task Management Plan for Groundwater Quality Monitoring Well Installation, ORNL/RAP/LTR-88/28, Martin Marietta Energy Systems, Inc., Oak Ridge National Laboratory, Oak Ridge, Tenn., February 1988. 
Appendix A

Data Packages 


\subsection{We11 Iocation}

Monitoring well number 985 is located in WAG 3 . It is in the northeast corner of WAG 3 . The location is shown on ORNL drawing number C3E20004 A075. Survey coordinates for this well are $N$ 21,833.8123, E 26,675.6115 (X-10 grid) or latitude $35^{\circ}-55^{\prime}-10.22^{\prime \prime}$ and longitude $84^{\circ}-19^{\prime}-43.65^{\prime \prime}$. Coordinate data were provided by Martin Marietta Energy systems. The method used for conversion from $x-10$ grid to Tennessee-Lambert state Plane coordinates came from the publication "Tennessee Valley Authority Data Services Branch and Mapping Services Branch, Oak Ridge, Tennessee, DOE Plant Control, November 6, 1985, Field Book: ESS-3115, pp. 1-20." The latitude and longitude were calculated by Adams Craft Herz Walker Engineering, Inc., using methods from the U.S. Coast and Geodetic survey Publication 62-4, "state Plane Coordinates by Automatic Data Processing."

\subsection{Drilling Information}

Well number 985 was drilled by Geotek Engineering Company. An Ingersoll-Rand Air Rotary rig was used to drill this boring for monitor well installation under operation of Larry Ledbetter with the assistance of Fred Dixon. Drilling commenced on 11-20-89 and was finished on 11-29-89. Paragraph 2.4.1 includes a detailed discussion of the well installation and a well schematic is included on the well installation/ completion form. A synopsis of the drilling activity 
follows. This information was typed directly from field notes and was edited only when necessary for clarification.

11-20-89 The Ingersoll-Rand was decontaminated along with the equipment and mobilized to the site. Plastic was layed down and the equipment set up. A 14.0" boring was augered to $7.0^{\prime}$ and a 10.0-inch diverter casing was installed and grouted in place.

11-27-89 The Ingersoll-Rand and equipment were decontaminated.

11-28-89 All drilling equipment was mobilized to the site and set up. An 8.0-inch boring was then advanced to 20.0 ' with a tricone bit. The boring was cleaned and after a 30 minute recharge no water was found in the borehole. A water sample and an air sample was taken at 20.0'. The boring was advanced to $30.5^{\prime}$, cleaned, and after a 45 minute recharge period, the water level was at $28.5^{\prime}$. The boring was then drilled to a depth of $35.0 \%$, and after a 45 minute recharge period the water level was at 31.5'. The rods were removed and the 2inch stainless steel screen and casing were installed to a depth of 35.0'. The sand was tremied and a bentonite seal poured.

11-29-89 The remaining annulus was tremie grouted. 
This well was logged by ERC Environmental and Energy Services Co., Inc., hydrogeologist c. Allison Bailey. All well construction materials and supplies were from Martin Marietta Energy Systems approved batches. The batch origin of individual items is shown on the included Monitoring Well Materials Certification form.

\subsection{Technical Information}

\subsection{Decontamination Procedures}

The drilling rig, down hole tools, surface casing, stainless steel screen, stainless steel casing, centralizers, and stainless steel silt trap underwent the cleaning decontam-ination procedures outlined in the drilling specifications (Release specific Technical Directions for Regulatory Compliance Monitoring Wells Phase 1, Oak Ridge National Laboratory, Oak Ridge, w.O. K-4147, April 1987, pgs. 2-4). A checklist of the cleaned materials is included with this data package.

\section{$2.2600109 y$}

WAG 3 is located in Melton Valley which is in the Valley and Ridge Physiographic Province of East Tennessee. WAG 3 is underlain by limestone, siltstone and shale of the Middle Ordovician Chickamauga Group. The Chickamauga Group consists of eight units, designated by letters "A" to "H" (Stockdale, 1951). WAG 3 is underlain by units $E, F, G$ and $H$. These units consist of thin bedded nodular limestone with clay and shale partings. A portion of unit $H$ and unit 
F consists of calcareous siltstone alternating with beds of olive gray to maroon shale. strike and dip varies from $N 45^{\circ} \mathrm{E}$ to $\mathrm{N} 5^{\circ} \mathrm{E}$ and $25^{\circ}$ to $35^{\circ}$ southeast, respectively.

\subsection{Bample collection}

A drill water sample was collected from the water pump on the drill rig on 11-28-89. Analytical results for this sample described above can be obtained from the Remedial Action Program data base at ORNL.

The Ingersoll-Rand Air Rotary Rig's compressed air was sampled with a cloth filter inserted between drill rods on 11-28-89. The sample was examined with an ultraviolet light for the presence of hydrocarbons. The filter indicated no detectable evidence of hydrocarbons.

\subsection{Installation and Development}

\subsubsection{Installation}

This was a "Type D" well. The air rotary method was required to complete the boring to the specified total well depth. Therefore, a 14.0-inch diameter boring was augered from ground surface to 7.0 feet and a 10.0-inch diameter diverter casing was installed and grouted. An 8-inch diameter boring was then drilled with an air rotary tricone roller bit from 7.0 to 35.0 feet. A 2-inch diameter stainless steel screen with welded bottom cap was installed from 35.0 to 20.0 feet. A 2-inch diameter stainless steel casing was 
ERC / EDGE

Environmental

and Energy

Services Co.

installed above the screen at 20.0 feet and extended 1.93 feet above ground surface. A sandpack was then tremied into the annular space from 35.0 to 16.55 feet, with a 2.68-foot bentonite pellet seal poured into the annular space above the sandpack from 16.55 to 13.87 feet. The annular space from the top of the bentonite seal to the surface was tremie-grouted with a cement/bentonite slurry. A detail of the well is included on the well installation/completion form. 2.4 .2

mell Development

Well number 985 was developed to remove drill cuttings, silt, and other fines. The monitoring well was developed using a Geoguard pump with an air compressor. All pumps were cleaned prior to use according to specified cleaning procedures (see Paragraph 2.1). The well was developed until a measured total of 100 gallons of water had been evacuated and the clarity of the discharge water was approved by the company representative. The final turbidity value measured at completion was 2.0 NTU's. A development form showing the exact method of development and other pertinent data is appended.

\subsubsection{Installation of Dedicated Monitoring Well Punp}

After the well was developed, a Geoguard Model No. 5614 dedicated monitoring well pump was installed on 4-17-90 at a depth of 33.4 feet below ground surface. These pumps are decontaminated at American sigma and are sent prepackaged. A copy of the pump certification is kept on file at ORNL. 
ERC / EDGE

Environmental

MONITORING WELL PROGRAM

and Energy

Services Co.

\subsection{Bydraulic Conductivity Testing}

Well number 985 was tested for the determination of hydraulic conductivity of the aquifer in the vicinity of the well screen. This was accomplished by instantaneously adding a known quantity of water to the monitoring well and measuring the recovery of the water level over time. The changing water levels were measured using a Druck 15 psig pressure transducer and an Omnidata Datapod II data recorder. The hydraulic conductivity value of $1.01 \times 10^{-5} \mathrm{~cm} / \mathrm{second}$ (shown as permeability on the hydraulic conductivity calculations printout attached) was calculated using the Bouwer and Rice method. A computer printout of the hydraulic conductivity calculations is included in this data package. 


\section{PRE-DRILLING CHECKLIST FOR MONITORING WELLS}

\section{RRE-DRILUNG TASKS}

1. EXCAVTION PERMIT OBTAINED

2. ALL EQUIPMENT HAS BEEN CLEANED BEFORE DRILLNG.

30. SCREEN AND CASING HAVE BEEN WASHED, STEAMED, RINSED WIH DE-IONIZED OR DISTILED WA TER, RINSED WTH ISOPROPY ALCOHOL, WRAPPED WTH PROTECTVE COVERING AND STORED OFF THE GROUND.

36. PRE-PACKAGED SCREENS, CASING AND CENTRALIZERS WERE USED.

4. WORK AREA FOR SAMPLE EXAMINATION COVERED WTH CLEAN POL YETHRENE.

5. CLEAN KNIVES, GLOVES, SAMPLE JARS AND LABELS ON HAND.

6. POL YETHRENE COVER IN PLACE OVER, HOLE.

7. AIR ROTARY COMPRESSED AIR SAMPLED.

COMPLIANCE

DAIE INIRALS

11-20-89 $C A B$

11-20-89 CAB

$\mathrm{N} / \mathrm{A}$

11-28-89 $C A B$

11-20-89 $C A B$

11-20-89 $C A B$

11-28-89 CAB

11-28-89 CAB

RESUL TS: No hydrocarbons detected on filter under ultraviolet light.

ADDITIONAL NOTES/OBSERVATONS:

OBSERVER SIGNATURE DATE $\frac{\text { C. COOWWubaily } 11 / 20 / 89}{\text { C. Allison Bailey }}$ 


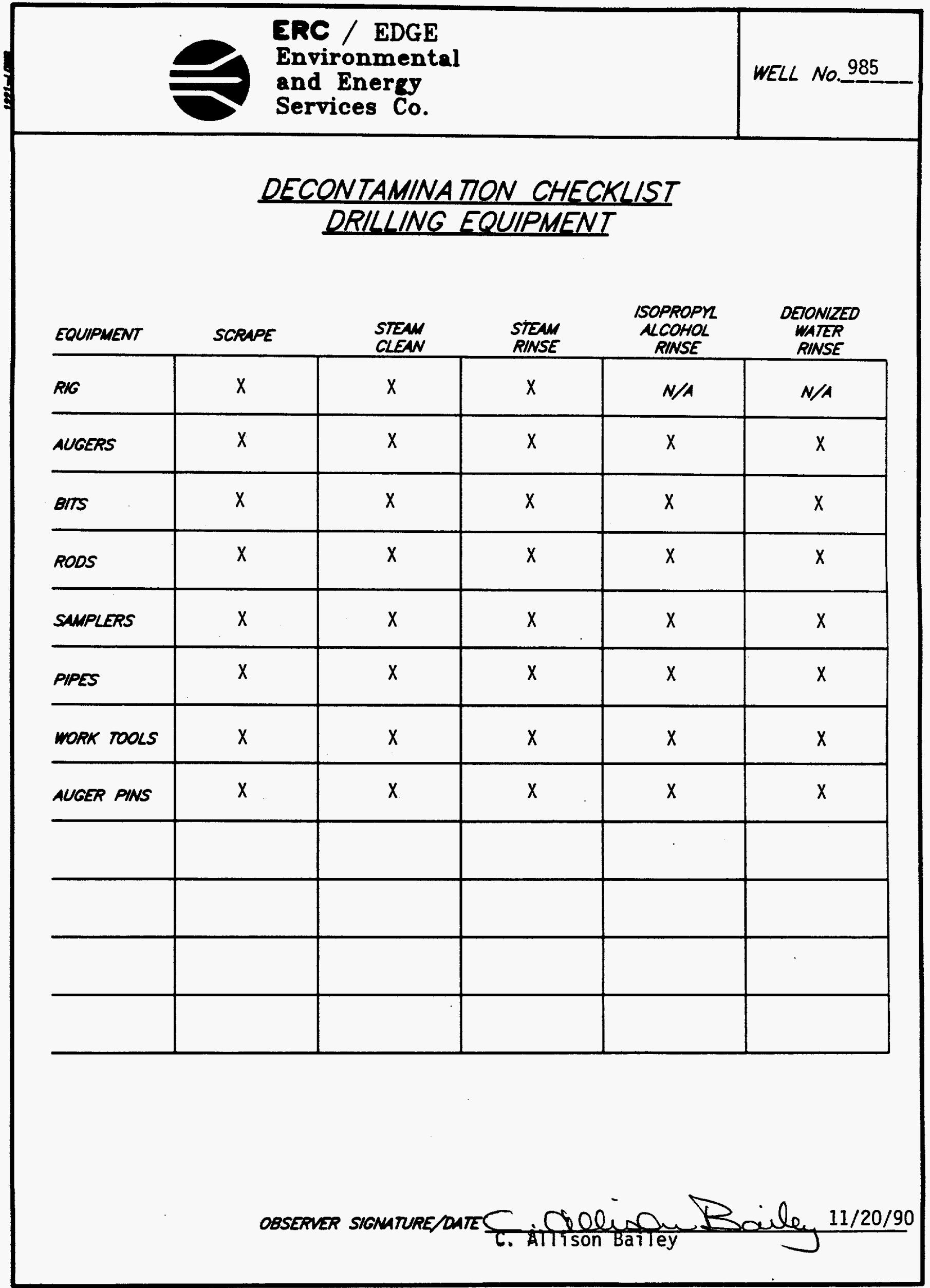




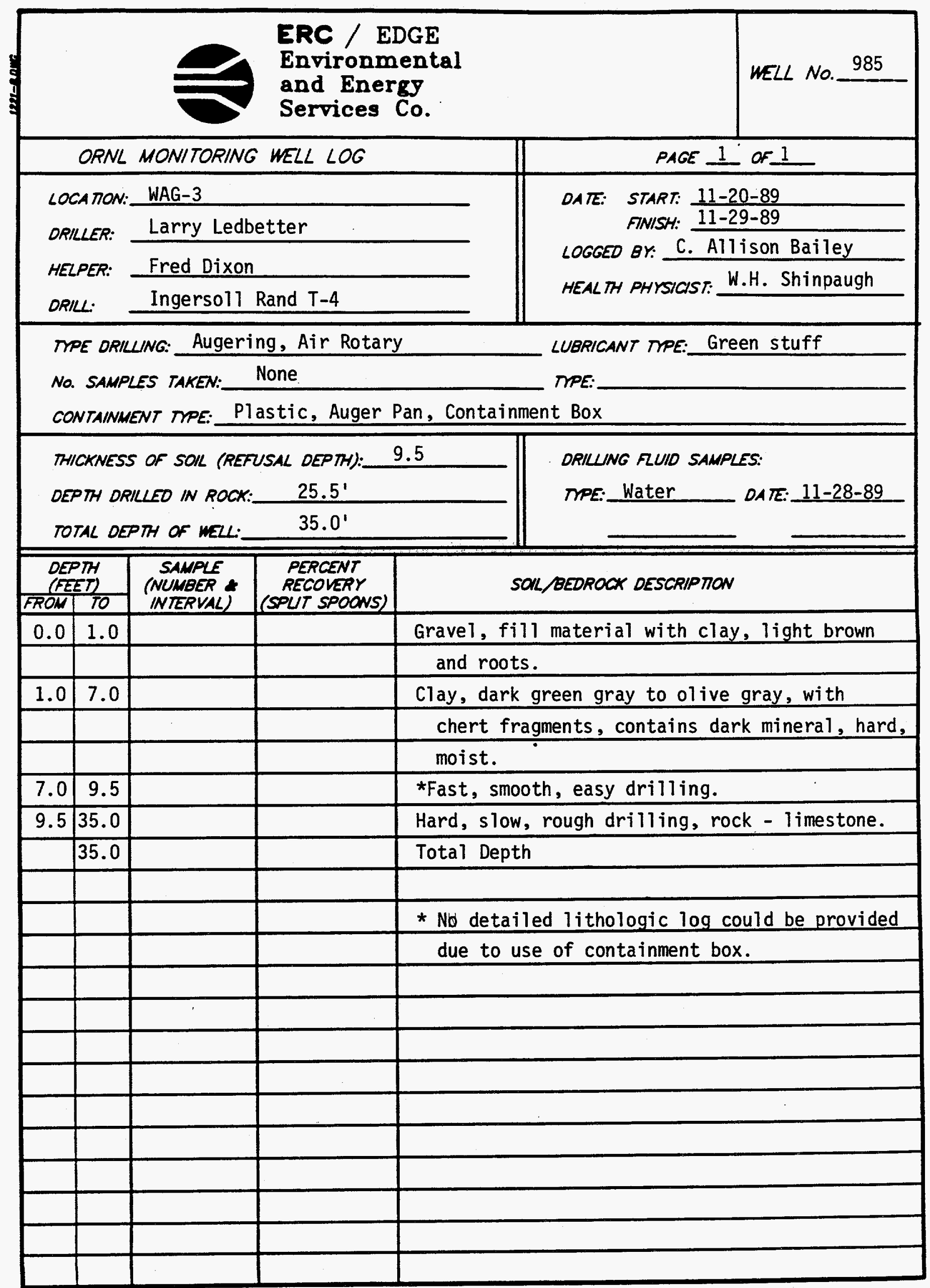




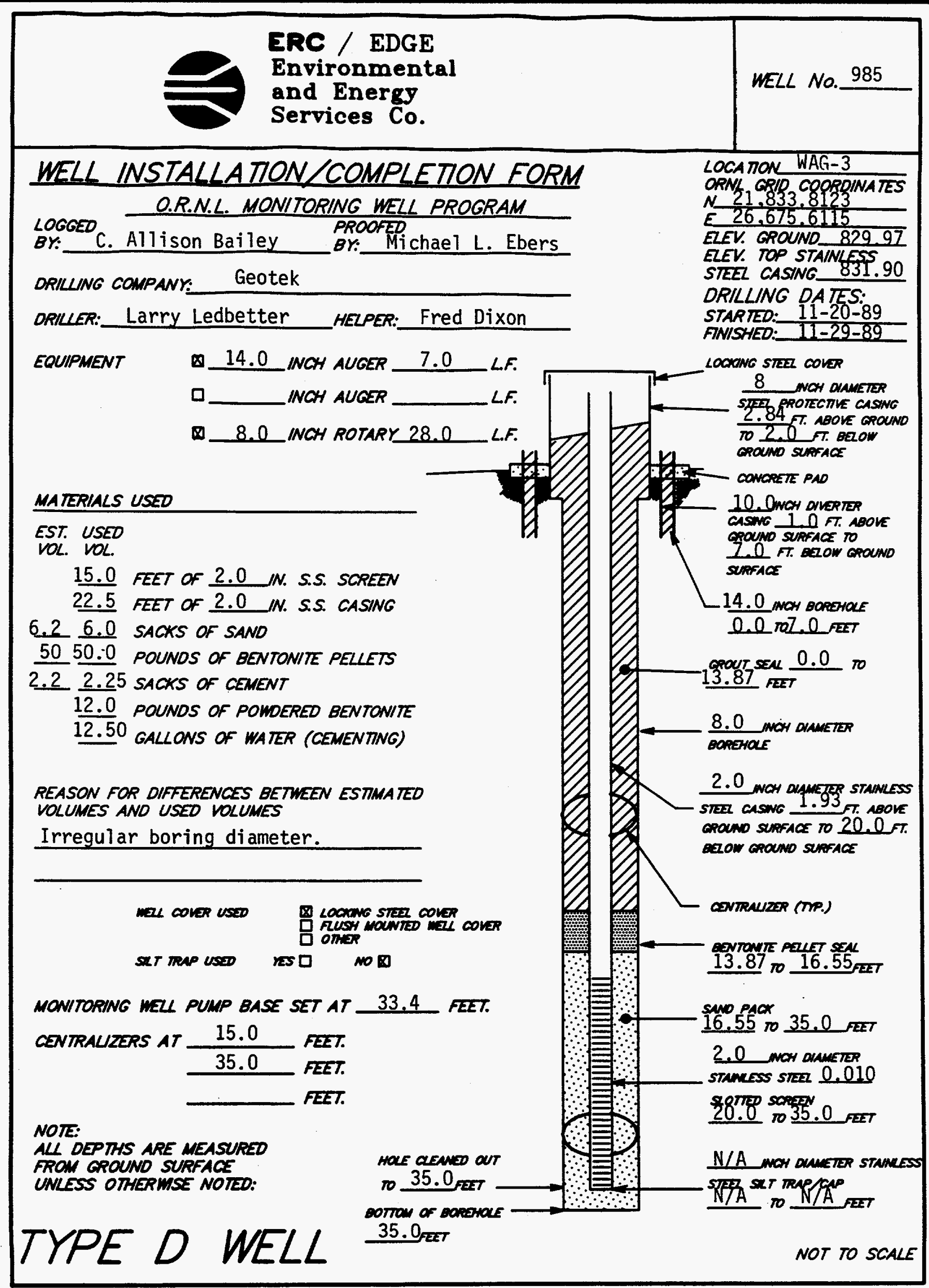

PACE 10 of 18. 


\section{MONITORING WELL MATERIALS CERTIFICATION}

\begin{tabular}{|c|c|c|}
\hline ITEM /MA TERIAL & DAIE USED & BATCH NUMBER \\
\hline \multirow{2}{*}{ SAND } & & \\
\hline & $11-28-89$ & 1 \\
\hline \multirow{2}{*}{ BENTONITE } & & \\
\hline & $11-28-89$ & Stores* \\
\hline STAINLESS STEEL SCREEN (PREPACKACED 0 RES) & $11-28-89$ & Stores * \\
\hline STAINLESS STEEL CASING (PREPACKAGED Q NOS) & $11-28-89$ & Stores* \\
\hline STAINLESS STEEL CENTRALIZERS (PREPACKACED 0 nO & $11-28-89$ & Stores * \\
\hline STAINLESS STEEL CAPS (PREPACKAGED Q NES & $11=28-89$ & Stores * \\
\hline (PAEPACKAGED $\mathrm{Q}$ MES & $4-17-89$ & 5 \\
\hline GROUT & $11-29-89$ & 3 \\
\hline WELL COVERS & $11-28-89$ & Stores* \\
\hline SURFACE CASING & $N / A$ & $N / A$ \\
\hline
\end{tabular}

COMMENTS:

* Surplus well completion supplies that were purchased but not used in the first monitor well drilling and installation phase (1987-1988).

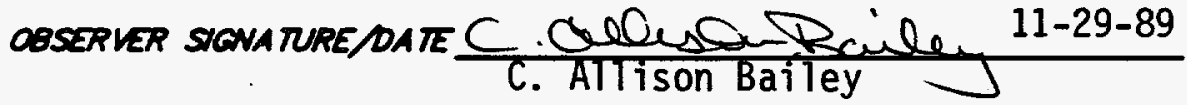




\begin{tabular}{|c|l|}
\hline $\begin{array}{l}\text { ENC / EDGE } \\
\text { Environmental } \\
\text { and Energy } \\
\text { Services Co. }\end{array}$ & WELL No._985 \\
\hline$\frac{\text { POST - WELL COMPLENION }}{\text { CHECKLIST }}$ \\
\hline
\end{tabular}

\section{POST-MELL COMPLETION TASKS}

$$
\begin{aligned}
& \text { COMPLIANCE } \\
& \text { DATE INITALS }
\end{aligned}
$$

1. MUO SCRAPED FRON AUGERS SAMPLERS ANO AL OTHER EQUIPMENT.

11-20-89 $C A B$

2. ALL WUO FROM RIG AND EOUIPNENT SCRAPINGS AND CUTTINGS DISPOSED OF IN ACCORDANCE WTH THE SPECFTCA HOW PROWDED.

3. WEU OEVEOPED IN ACCOPOANCE WTH THE SPECFFCA TON PROMOED AND DETALS OF THE OEVZLOPMENT ACTUTY RECOROED.

4. DRULWG STE PROPERLY CLEANED UP AFTER COMPLETION OF MEL INSTALLATION.

11-20-89 $\quad C A B$

4-17-90 DCL

$11-28-89 \quad C A B$

- RELEASE SPECATC TECHNCAL DIRECTONS FOR REQULATORY COMPUANCE MONITORING MELLS PHASE 1, OAK RIDEE NATIONAL LABORATORY, OAK RIDEE, W.O. K-4147. APRIL 1987.

$$
\begin{aligned}
& \text { OESERVER SIGATURE/OAIf. Cleand Baily 11-28-89 } \\
& \text { D. Chalesplete 4-17-90 }
\end{aligned}
$$




\section{MONITORING WELL \\ DEVELOPMENT FORM}

DEVELOPMENT DETAILS

METHOD OF

DEVELOPMENT: Surging and Pumping

DEVELOPMENT

BEGAN DATE: $\quad 4 / 04 / 90$ TME:

DEVELOPMENT

ENDING DATE: $\quad 4 / 17 / 90$

DEVELOPMENT

OBSERVED BY:

D. Charles Lytle

ONE WELL VOLUME: 11.8 GALLONS

TOTAL GALLONS PUMPED: 100 TOTAL WELL VOLUMES PUMPED: 8.5

INITAL PH: $7.4 \quad$ FNAL PH: 7.4

INITAL CONOUCTUTY ( $\mathrm{KS} / \mathrm{cm}$ ): 076 FNAL CONDUCTUTH ( $\mathrm{HS} / \mathrm{cm}$ ): 069

DESCRIPTON OF INITAL TURBIDITY: STightly Cloudy

DESCRIPTION OF FINAL TURBIDITY: Clear

FNAL MEASURED TURBIDITY:

20 NTW's

MELL APPROVED BY:

R. C. Williams MMES

ODOR

OF MAIER:

WATER

DISCHARGED

TO:

GROUND SURFACE

口 TANK TRUCK

I STORAGE TANKS

口 STORM SEWERS

O OTHER

INITAL PRE-DEVELOPMENT WA TER DEPTH:

6.9 feet from ground surface.

DEVELOPMENT OBSERVATIONS

OBSERVER SIGNATURE/DATE D.Chaleolytle 4/17/90

D. Charles Lytle 


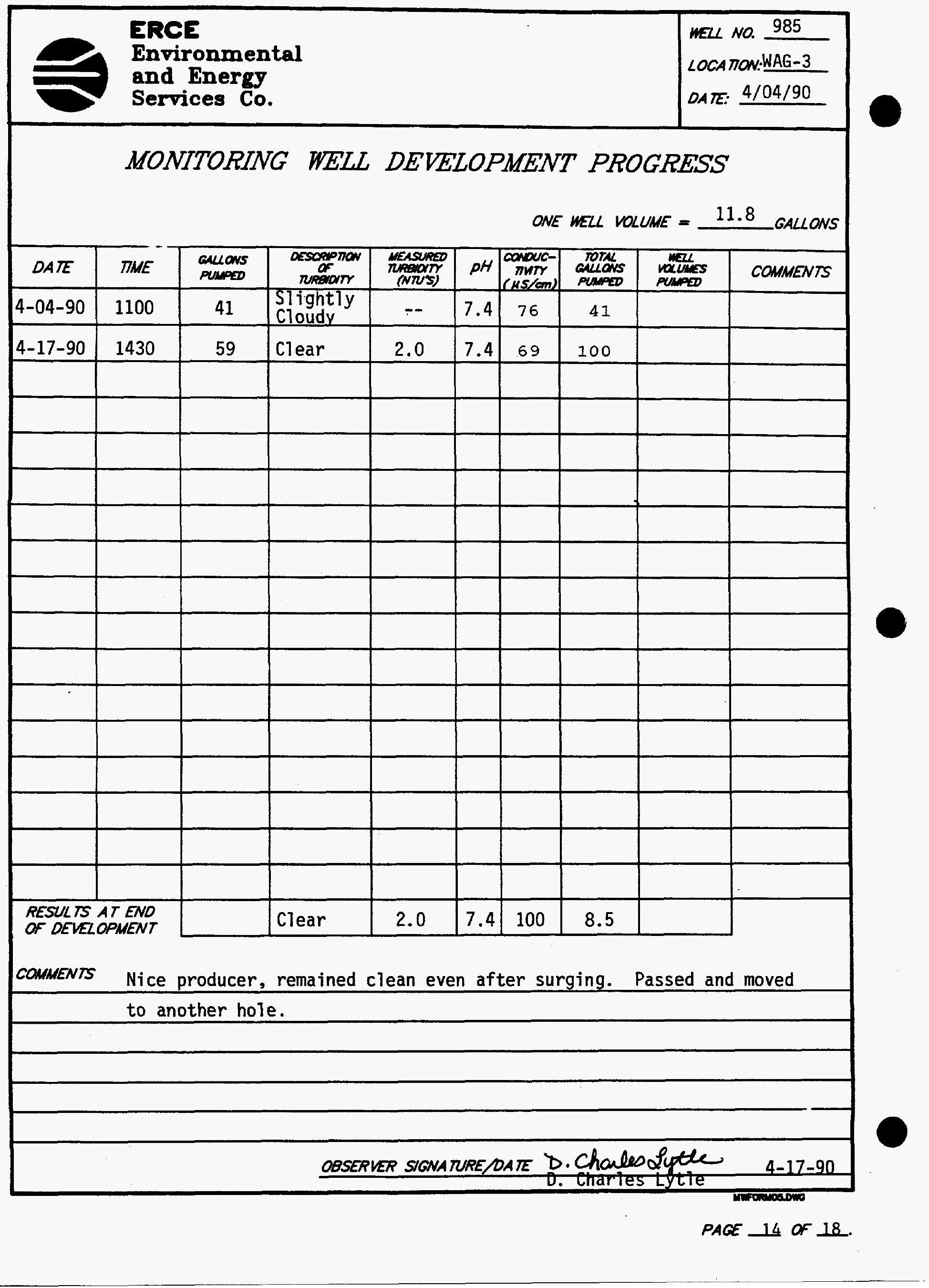




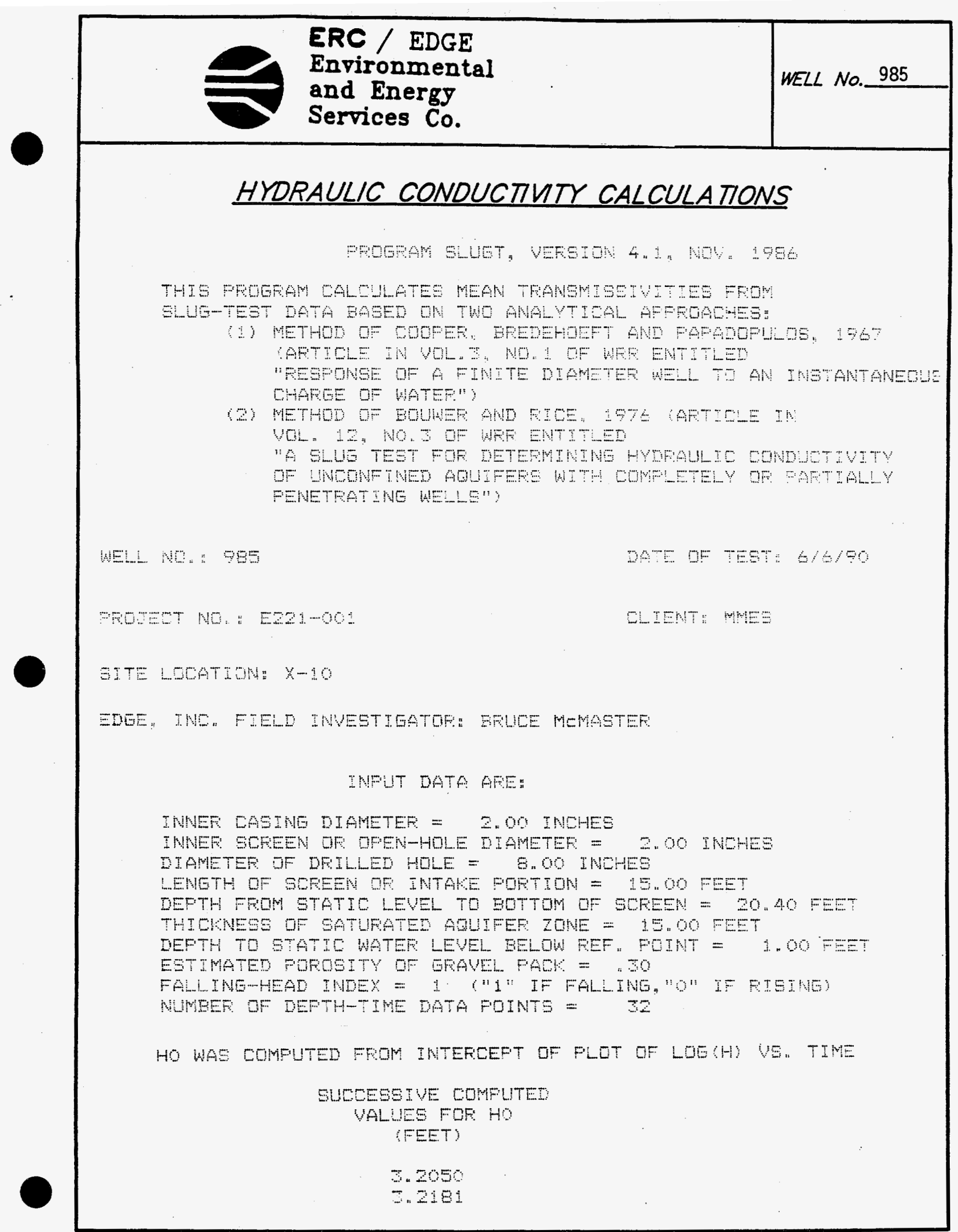

PAGE 15 or 18 


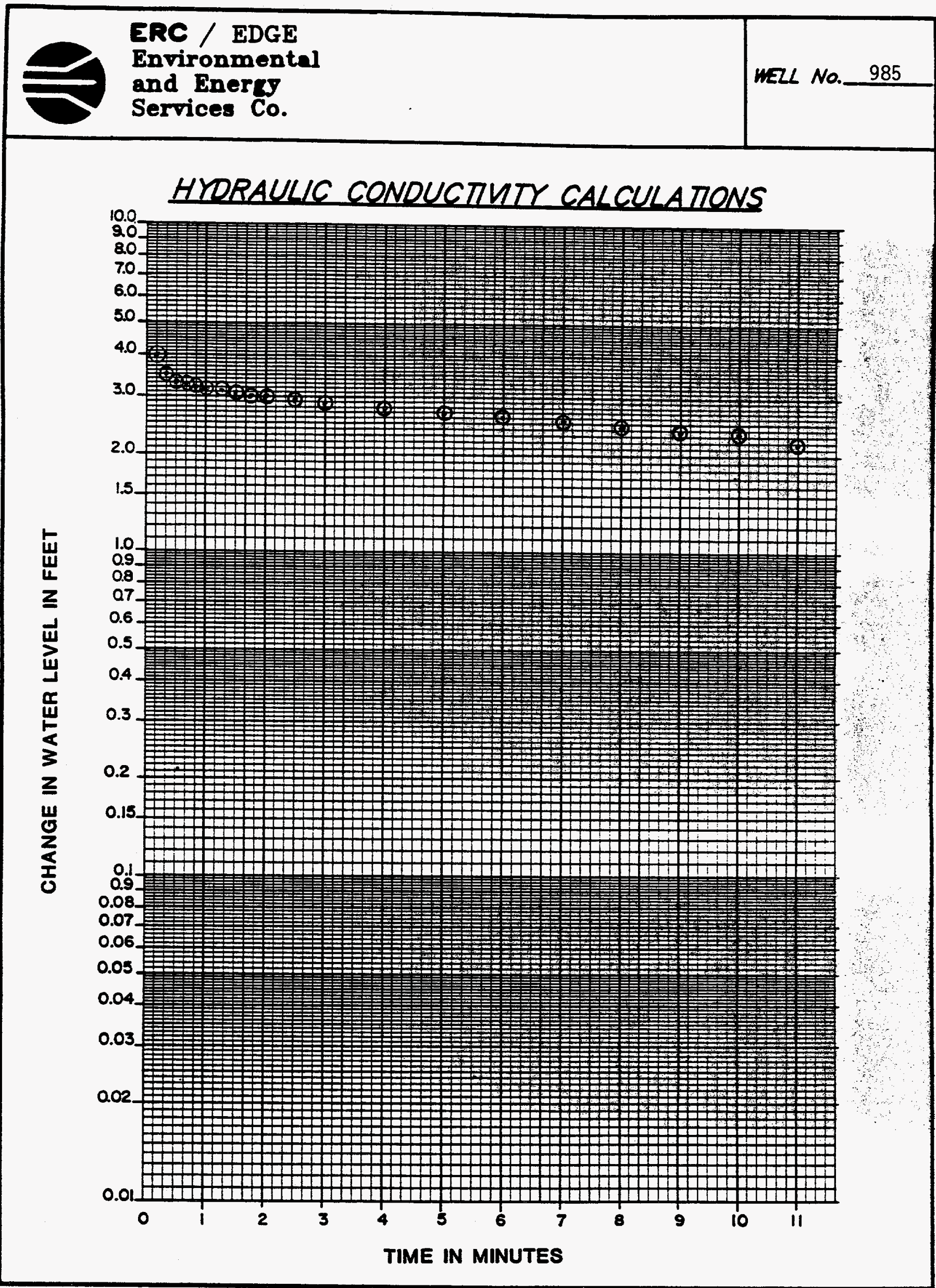

PACE 17 or 18 


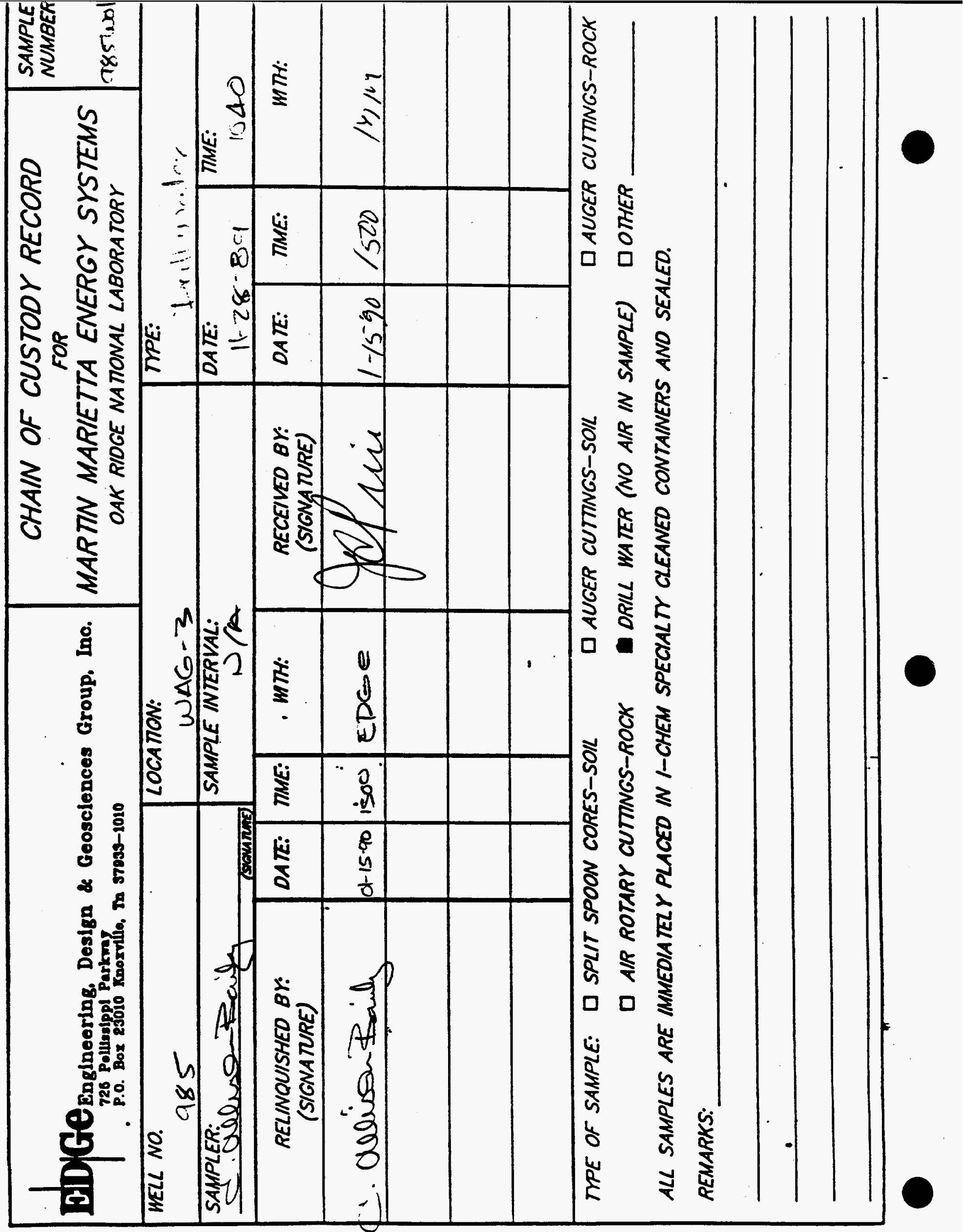


ERC / EDGE

Environmental

and Energy

Services Co.

\subsection{General Information}

\subsection{Well Iocation}

Monitoring well number 986 is located in WAG 3 . It is along the eastern perimeter of WAG 3. The location is shown on ORNL drawing number C3E20004 A075. Survey coordinates for this well are $N$ 21,813.1583, E 26,674.6725 (X-10 grid) or latitude $35^{\circ}-55^{\prime}-10.04^{\prime \prime}$ and longitude $84^{\circ}-19^{\prime}-43.52^{\prime \prime}$. Coordinate data were provided by Martin Marietta Energy systems. The method used for conversion from $x-10$ grid to Tennessee-Lambert state Plane coordinates came from the publication "Tennessee Valley Authority Data Services Branch and Mapping Services Branch, Oak Ridge, Tennessee, DOE Plant Control, November 6, 1985 , Field Book: ESS-3115, pp. 1-20." The latitude and longitude were calculated by Adams Craft Herz Walker Engineering, Inc., using methods from the U.S. Coast and Geodetic Survey Publication 62-4, "State Plane Coordinates by Automatic Data Processing."

\subsection{Drilling Information}

Well number 986 was drilled by Geotek Engineering Company. An Ingersoll-Rand T-4 Air Rotary rig was used to drill this boring for monitor well installation under operation of Larry Ledbetter with the assistance of Fred Dixon. Drilling commenced on 11-9-89 and was finished on 11-20-89. Paragraph 2.4.1 includes a detailed discussion of the well installation and a well schematic is included on the well installation/completion form. A synopsis of the 


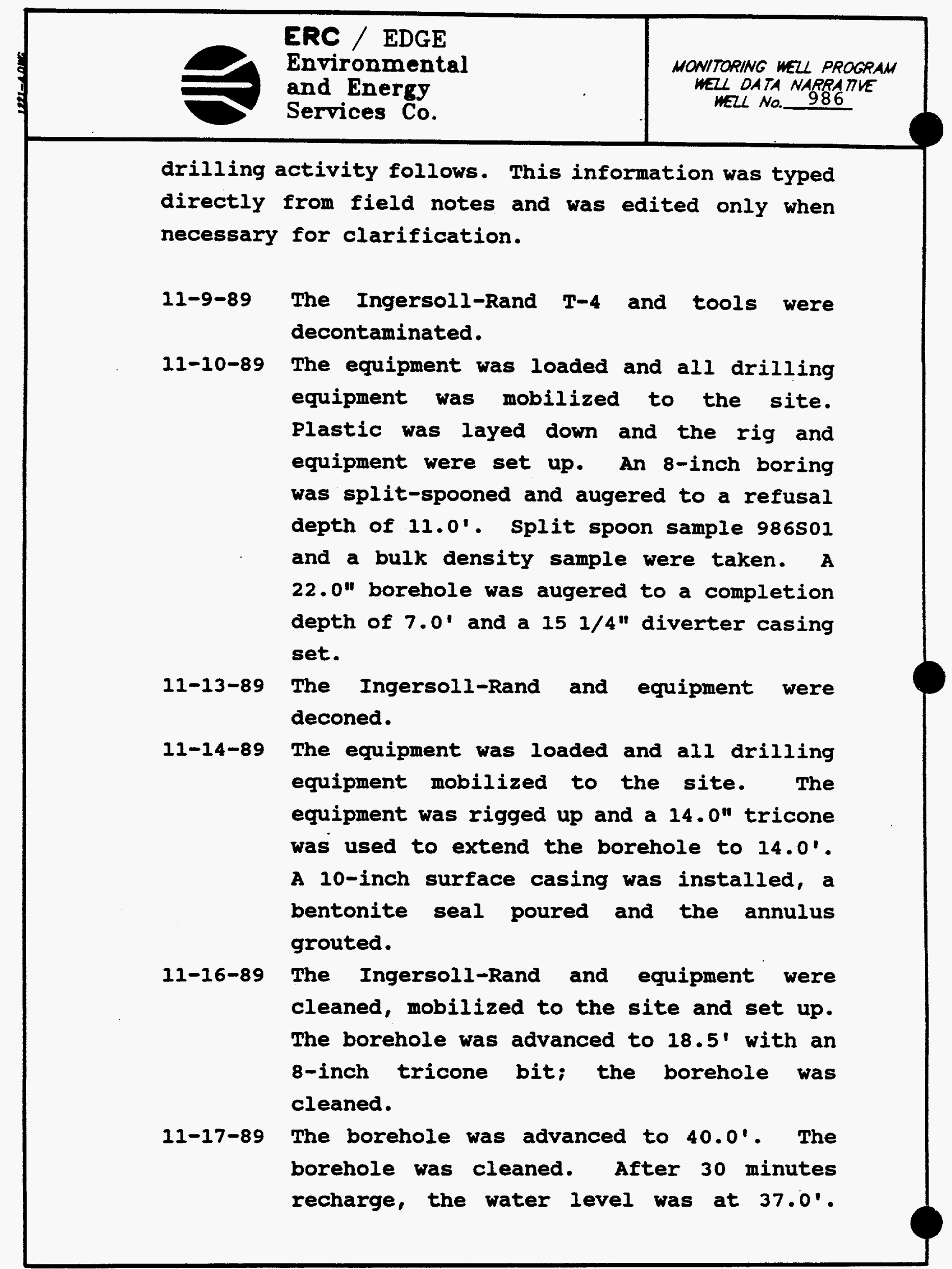


ERC / EDGE

Environmental

and Energy

Services Co.

The boring was then advanced to $50.0^{\prime}$ and after a 15 minute wait, the water level was at $46.5 \mathrm{H}$, and after 30 minutes, the water level was at $42.5 \%$. The boring was then advanced to 62.5 '. A drill water sample was taken at $51.0^{\prime}$ and an air sample taken at 60.0 '. After a 5 minute wait the water level was at 47.51 .

11-20-89 The 4-inch stainless steel casing and screen was installed. The sand was tremied into place with water and a bentonite seal poured. The annulus of the boring was then grouted through 1-inch tremie.

This well was logged by ERC Environmental and Energy Services Co., Inc., hydrogeologist C. Allison Bailey. All well construction materials and supplies were from Martin Marietta Energy Systems approved batches. The batch origin of individual items is shown on the included Monitoring Well Materials Certification form.

\subsection{Technioal Information}

\subsection{Decontamination Procedures}

The drilling rig, down hole tools, surface casing, stainless steel screen, stainless steel casing, centralizers, and stainless steel silt trap underwent the cleaning decontamination procedures outlined in the drilling specifications (Release specific Technical Directions for Regulatory Compliance Monitoring Wells Phase 1, Oak Ridge National Laboratory, Oak Ridge, W.O. K-4147, April 1987, 


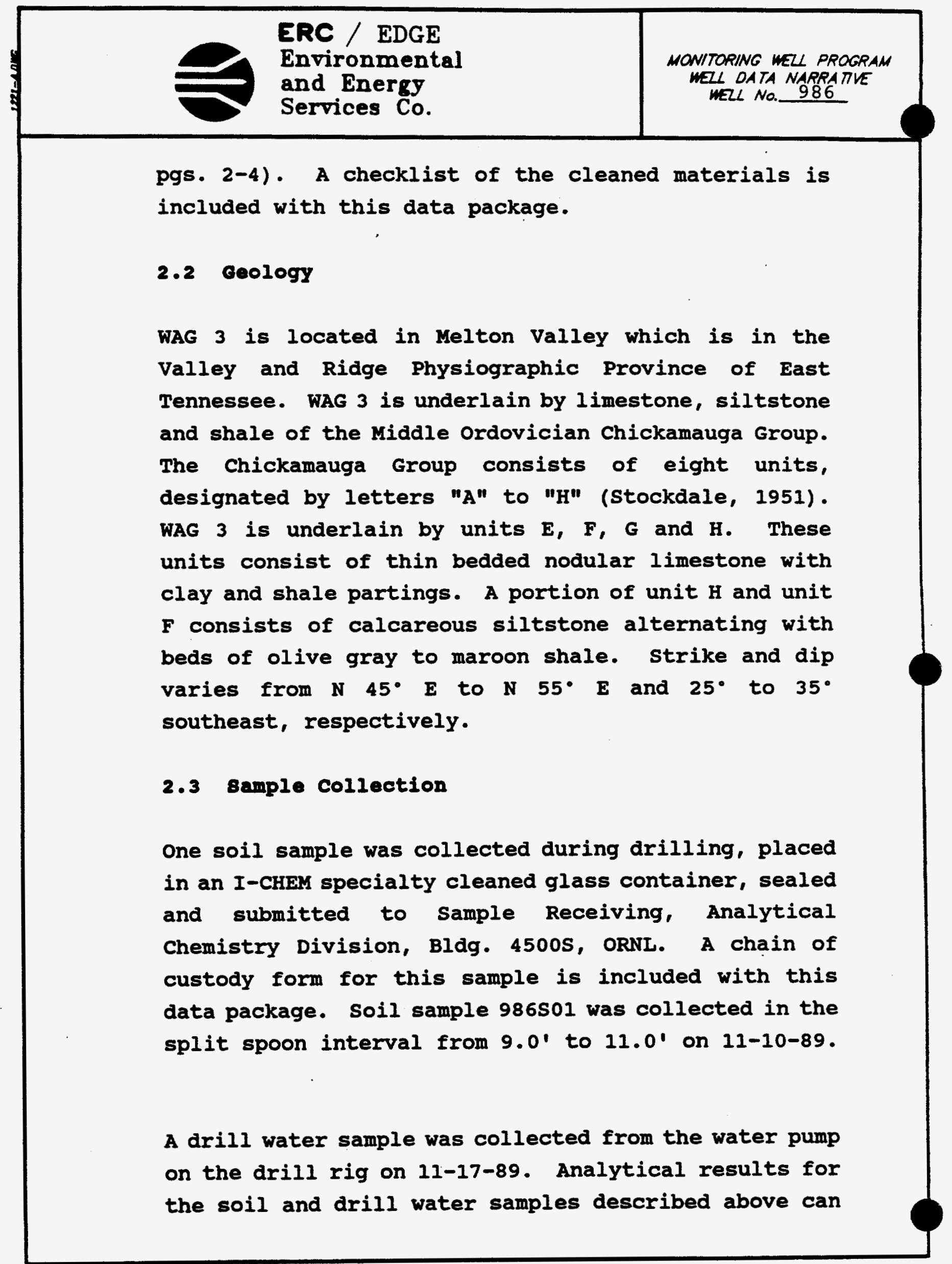


ERC / EDGE

Environmental

and Energy

Services Co.

be obtained from the Remedial Action Program data base at ORNL.

A bulk density soil sample was collected from the split spoon sample interval from 5.2 ' to 5.51 . The sample was measured and weighed, and a bulk density of $2.17 \mathrm{grams} / \mathrm{cm}^{3}$ was calculated.

The Ingersoll-Rand T-4's compressed air was sampled with a cloth filter inserted between drill rods on 11-17-89. The sample was examined with an ultraviolet light for the presence of hydrocarbons. The filter showed no detectable evidence of hydrocarbons.

\subsection{Installation and Development}

\subsubsection{Installation}

This was a "Type B" well. An 8-inch boring was point split spooned and augered from 0.0 ' to a refusal depth of 11.0'. A 22.0-inch diameter boring was augered from ground surface to 7.0 feet. A 15 1/4-inch diverter casing was installed from surface to 7.0 feet below ground surface and grouted in place. The boring was then extended past the refusal depth with a 14.0inch air rotary tricone roller bit from 7.0 feet to 14.0 feet. A 10.0-inch diameter string of decontaminated steel surface casing was installed from 0.0 feet to 14.0 feet, sealed with a 2.0-foot bentonite pellet layer from 12.0 feet to 14.0 feet, and tremie grouted in place. The surface casing minimizes potential cross contamination between the regolith and bedrock water bearing zones. After the 
surface casing was installed, the air rotary method was used to drill an 8-inch diameter boring to a total depth of 62.5 feet. A 4-inch diameter stainless steel screen with a silt trap was installed from 62.0 feet to 41.70 feet. A 4-inch diameter stainless steel casing was installed from the top of the screen at 41.70 feet and extended 1.87 feet above ground surface. A sandpack was then tremied into the annular space from 62.0 to 39.15 feet, with a 2.44-foot bentonite pellet seal poured into the annular space above the sandpack from 39.15 to 36.71 feet. The annular space from the top of the bentonite, seal to the surface was tremie grouted with a cement/bentonite slurry. A detailed schematic of the well is included on the well installation/completion form.

\subsubsection{Well Development}

Well number 986 was developed to remove drill cuttings, silt, and other fines. The monitoring well was developed using a Geoguard pump with an air compressor. All pumps were cleaned prior to use according to specified cleaning procedures (see Paragraph 2.1). The well was developed until a measured total of 653 gallons of water had been evacuated and the clarity of the discharge water was approved by the company representative. The final turbidity value measured at completion was $2.0 \mathrm{NTU}$ 's. A development form showing the exact method of development and other pertinent data is appended. 


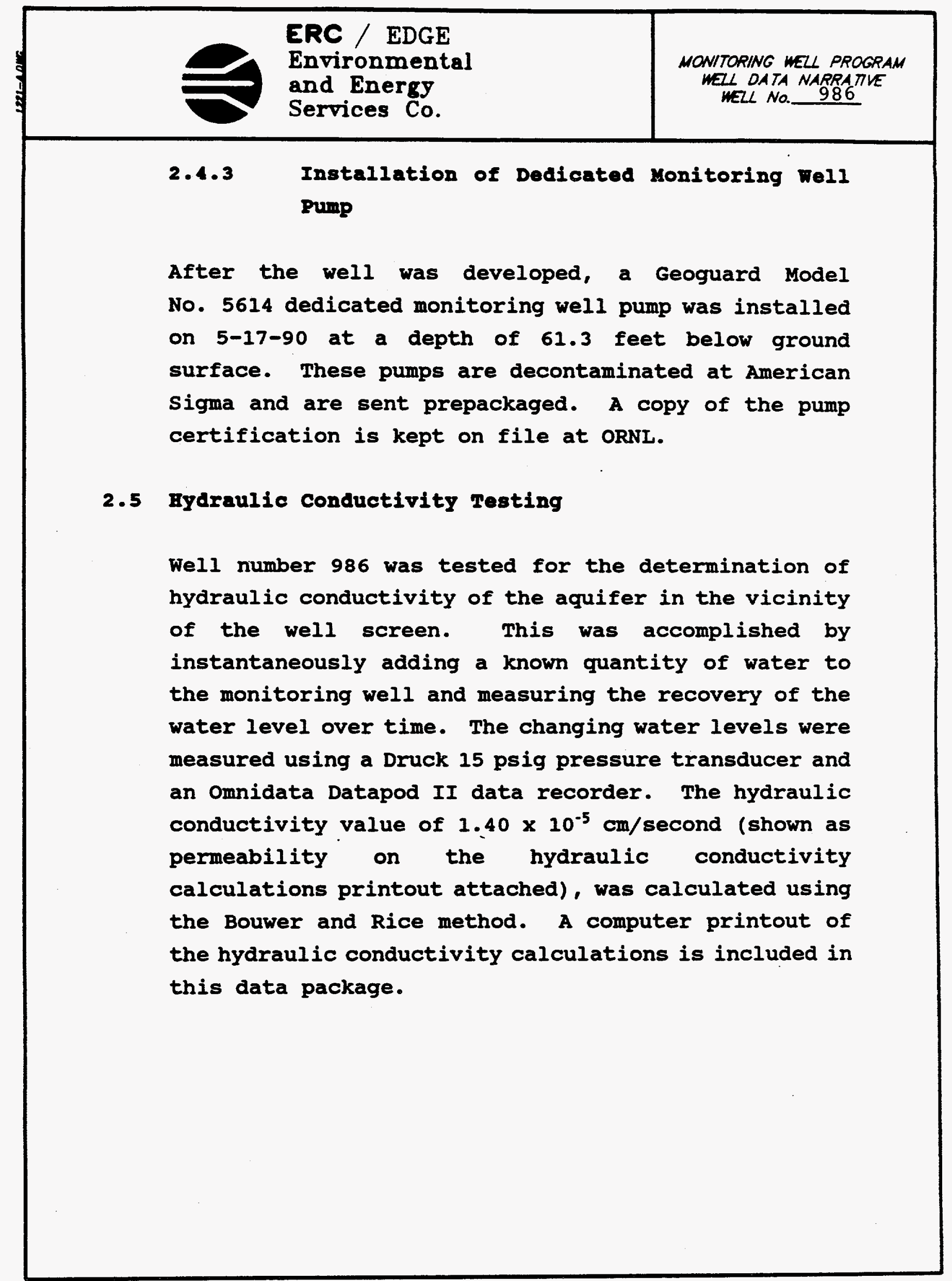




\section{PRE-DRILLING CHECKLIST FOR MONITORING WELLS}

RRE-DRILUNG TASKS

1. EXCAVTION PERMIT OBTAINED

$\frac{\frac{2 A T E}{11-10-89}}{\frac{1 N 17 A L S}{C A B}} \frac{C A B}{N / A}$
RINSED WIH DE-IONIZED OR DISTLLED WATER, RINSED WTH ISOPROPV ALCOHOL, WRAPPED WTH PROTECTVE COVERING AND STORED OFF THE GROUND.

36. PRE-PACKAGED SCREENS, CASING AND CENTRALIZERS WERE USED.

4. WORK AREA FOR SAMPLE EXAMUNATION COVERED WTH 11-10-89 CAB CLEAN POL RETHRENE.

5. CLEAN KNIVES, GLOVES, SAMPLE JARS AND LABEZS ON HAND.

6. POLYETHRENE COVER IN PLACE OVER HOLE.

$\frac{11-10-89}{11-17-89}$ CAB

7. AIR ROTARY COMPRESSED AIR SAMPLED. RESULS: No hydrocarbons detected under ultraviolet light.

ADOITONAL NOTES/OBSERVATIONS:

OBSERVER SIGNATURE DATE $\frac{d \text {. ColesouBaly 11-20-89 }}{\text { C. Allison Bailey }}$ 
ERC / EDGE

Environmental

and Enerey

WELL NO. 986

DECONTAMINATION CHECKLIST

DRILLING EQUIPMENT

\begin{tabular}{|c|c|c|c|c|c|}
\hline EQUIPMENT & SCRAPE & $\begin{array}{l}\text { STENW } \\
\text { CLEN }\end{array}$ & $\begin{array}{l}\text { STENM } \\
\text { RINSE }\end{array}$ & $\begin{array}{c}\text { ISOPROPY } \\
\text { NCOHOL } \\
\text { RINSE }\end{array}$ & $\begin{array}{c}\text { DEIONIZED } \\
\text { WATER } \\
\text { RINSE }\end{array}$ \\
\hline$R / G$ & $x$ & $x$ & $x$ & $N / A$ & $N / A$ \\
\hline AUGERS & $x$ & $x$ & $x$ & $x$ & $x$ \\
\hline BITS & $x$ & $x$ & $X$ & $x$ & $x$ \\
\hline ROOS & $x$ & $x$ & $x$ & $x$ & $x$ \\
\hline SAMPLERS & $x$ & $x$ & $x$ & $x$ & $x$ \\
\hline PIPES & $x$ & $x$ & $x$ & $x$ & $x$ \\
\hline WORK TOOLS & $x$ & $x$ & $x^{\bullet}$ & $x$ & $x$ \\
\hline AUGER PINS & $x$ & $x$ & $x$ & $x$ & $x$ \\
\hline & & & & & \\
\hline & & & & & \\
\hline & & & & & \\
\hline & & & & & \\
\hline
\end{tabular}

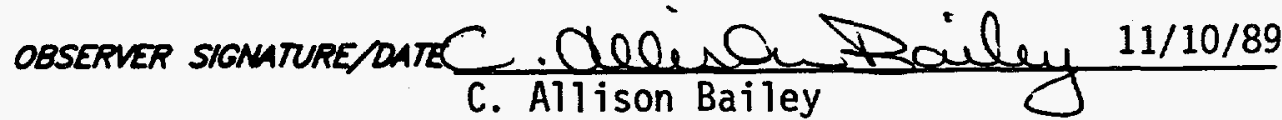

PAGE 9 OF 22. 


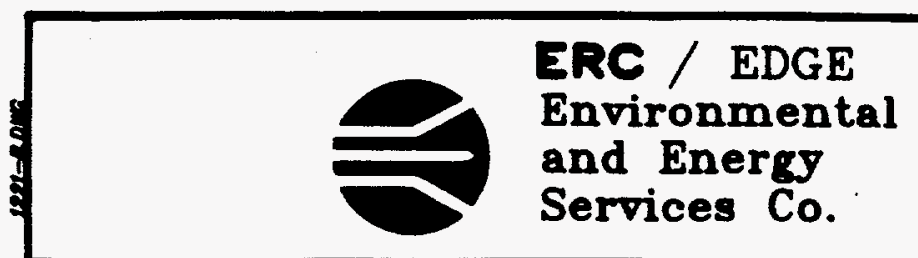

ORNL MONITORING WELL LOG

LOCA MON: WAG-3

DRILLER: Larry Ledbetter

HELPER: Fred Dixon

ORILL: Ingersoll Rand $\mathrm{T}-4$

PAGE 1 of 3

DATE: START: $11-10-89$

FNISH: 11-20-89

LOGGED BY: C. All ison Bailey

HEALTH PHYSICIST: W. H. Shinpaugh

TrPE ORILLING: Split spoon. Auger, Air Rotary

No. SAMPLES TAKEN: One (986-SO1)

LUBRICANT MPE:_Green stuff

CONTAINMENT MPE: Plastic, Pan, Containment Box

MPE: SO

THICKNESS OF SOL (REFUSAL OEPTH): 11.0

OEPTH DRILLED IN ROCK: 51.5

TOTAL DEPTH OF WELL: 67.5

\begin{tabular}{|c|c|c|c|c|}
\hline \multicolumn{2}{|c|}{$\begin{array}{l}\text { OEPTH } \\
\text { (FEET) } \\
\end{array}$} & $\begin{array}{l}\text { SAMPLE } \\
\text { (NUMBER } \\
\text { INTERVAL) }\end{array}$ & $\begin{array}{c}\text { PERCENT } \\
\text { RECOVERY } \\
\text { (SPUT SPOONS) }\end{array}$ & SOL/BEDROCK OESCRIPION \\
\hline \multirow[t]{3}{*}{0.0} & 1.4 & & $50 \%$ & Clay, light brown, with roots, gravel and chert. \\
\hline & & & & Chert is white, brittle, and has iron stains. \\
\hline & & & & Clay is moist. \\
\hline \multirow[t]{3}{*}{1.4} & 2.0 & & & Clay, dark green gray to olive gray. \\
\hline & & & & some chert fragments. Clay is firm and \\
\hline & & & & moist. \\
\hline \multirow[t]{3}{*}{2.0} & 3.0 & & $90 \%$ & Clay, dark gray to dark greenish gray. Clay \\
\hline & & & & is firm to crumbly and damp. Contains some \\
\hline & & & & roots and decayed organic material. \\
\hline \multirow[t]{3}{*}{3.0} & 4.0 & & & Clay, dark yellowish brown to brownish gray, \\
\hline & & & & firm to crumbly, damp, consolidated. \\
\hline & & & & Contains some roots. \\
\hline \multirow[t]{4}{*}{4.0} & 6.0 & & $80 \%$ & Clay, mottled, light brown and olive gray with \\
\hline & & & & dark mineral specks. Clay is hard, firm and \\
\hline & & & & cold. Bulk density taken from 5.2 to $5.5^{\prime}=$ \\
\hline & & & & $2.2 \mathrm{grams} / \mathrm{cm}^{3}$ \\
\hline \multirow[t]{3}{*}{6.0} & 7.0 & & $100 \%$ & Clay, mottled, light brown, olive gray and \\
\hline & & & & medium gray, speckled with dark mineral \\
\hline & & & & Hard, firm and damp. \\
\hline \multirow[t]{2}{*}{7.0} & 7.8 & & $100 \%$ & Clay, mottled, light brown, olive gray and \\
\hline & & & & medium gray, speckled with dark mineral \\
\hline
\end{tabular}




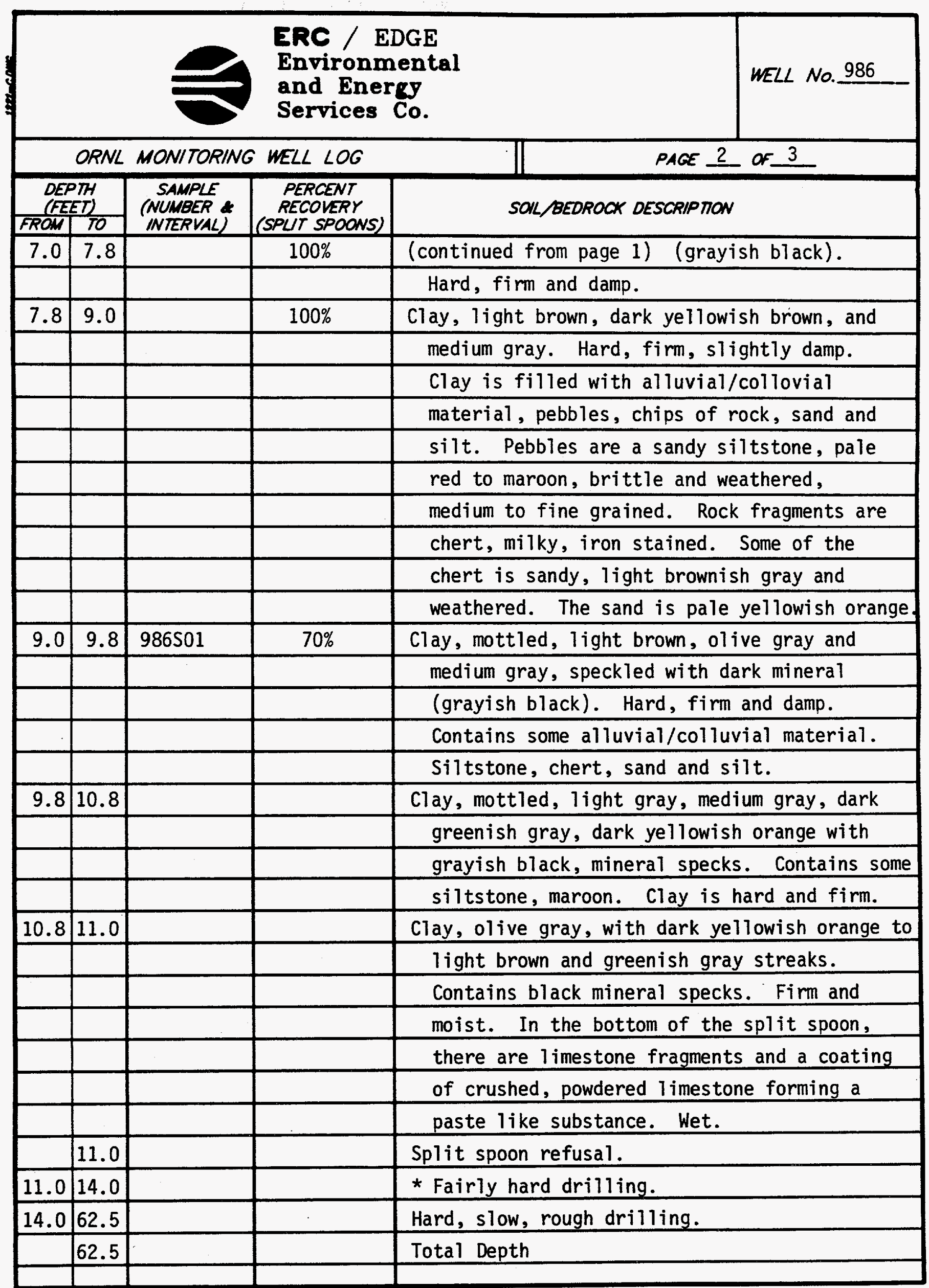




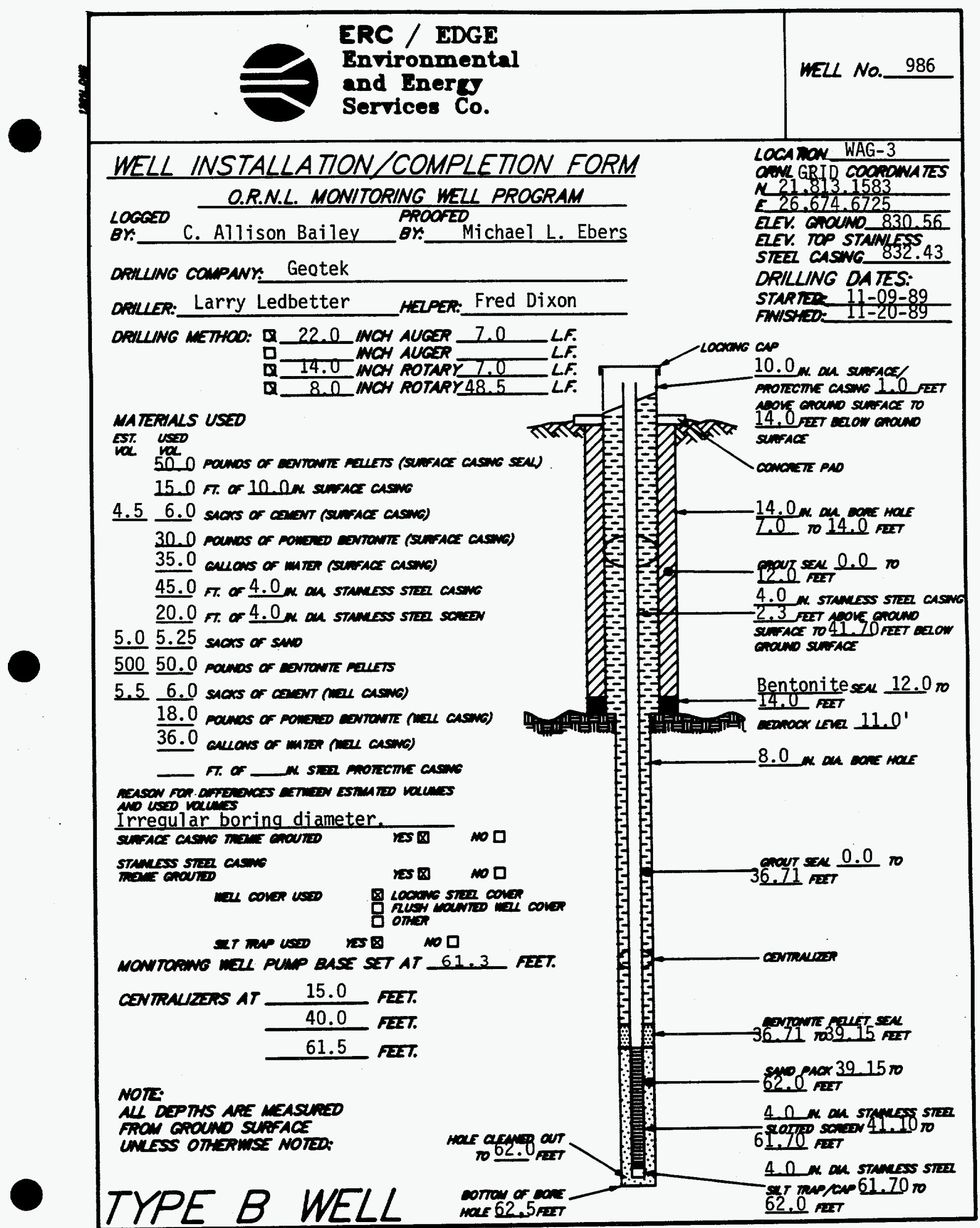

PAEF 13 or 22 


\section{MONITORING WELL MATERIALS CERTIFICATION}

\begin{tabular}{|c|c|c|}
\hline ITEM/MA TERIAL & DAIE USED & BATCH NUMAER \\
\hline SAND & $11-20-89$ & 1 \\
\hline \multirow{2}{*}{ BENTONITE } & $11-14-89$ & 1 \\
\hline & $11-20-89$ & Stores* \\
\hline (PREPACKaCED $\left.0 \begin{array}{cc}\text { RES } \\
\text { nO }\end{array}\right)$ & $11-20-89$ & Stores* \\
\hline 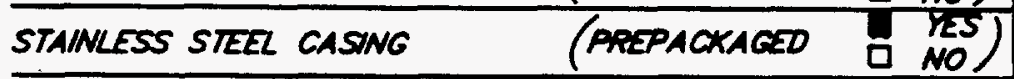 & $11-20-89$ & Stores* \\
\hline STAINLESS STEEL CENTRALIZERS (PREPACKACED $\left(\begin{array}{c}\text { YES } \\
\text { NO }\end{array}\right.$ & $11-20-89$ & Stores* \\
\hline STAMLESS STEER CAPS (PREPACKAGED D $\left.\begin{array}{c}\text { VES } \\
\text { NO }\end{array}\right)$ & $11-20-89$ & Stores* \\
\hline (PREPACKAGED $\left.0 \begin{array}{c}\text { YES } \\
\text { NO }\end{array}\right)$ & $5-17-90$ & 5 \\
\hline \multirow[t]{2}{*}{ GROUT } & $11-14-89$ & 3 \\
\hline & $11-20-89$ & 3 \\
\hline WELL COVERS & $11-20-89$ & Stores * \\
\hline SURFACE CASING & $11-14-89$ & 3 \\
\hline
\end{tabular}

COMMENTS:

* Surplus well completion supplies that were purchased but not used in the first monitor well drilling and installation phase (1987-1988).

OBSERVER SIONATUREPATE C. OllenDal Raly 11-20-89 


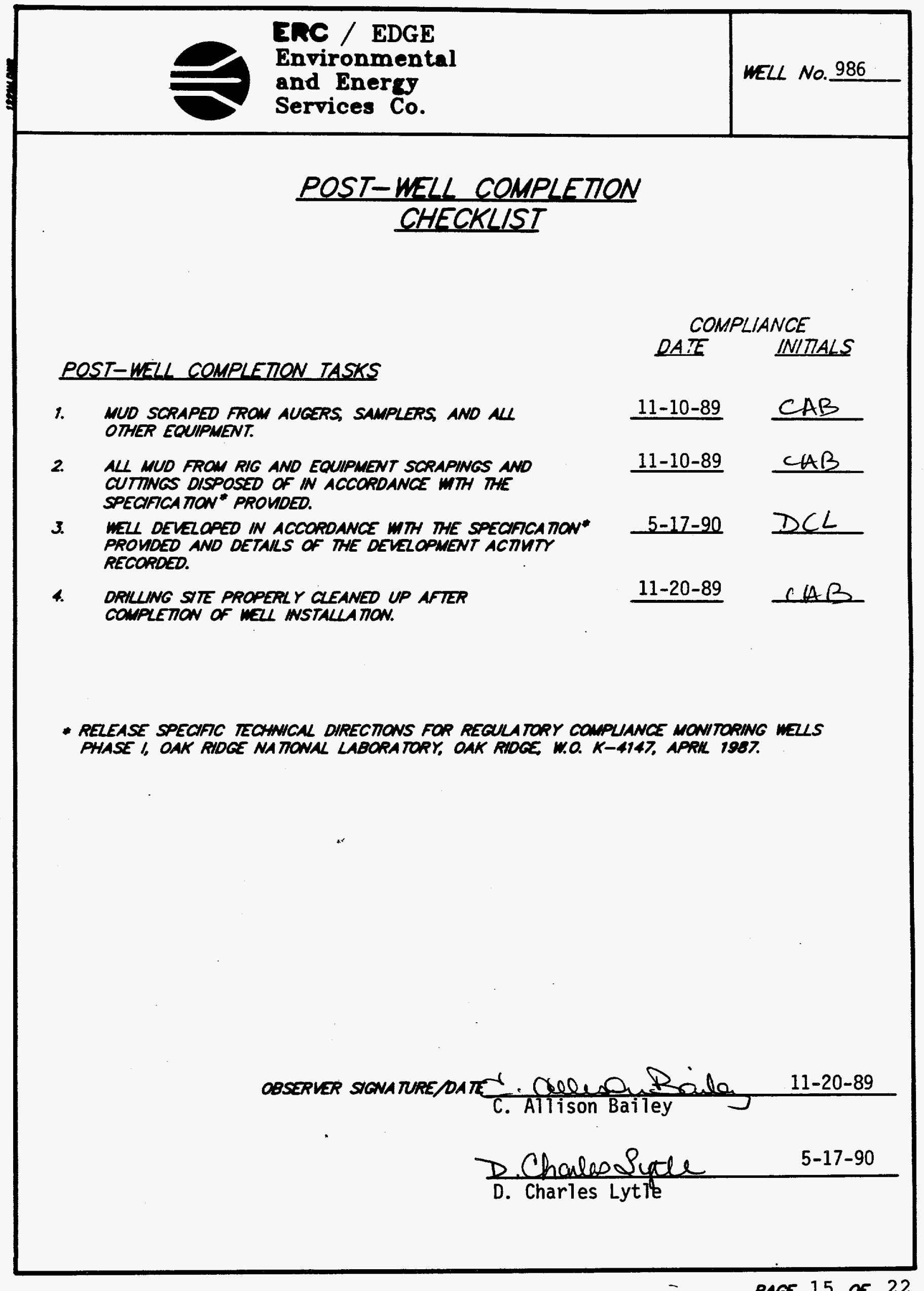




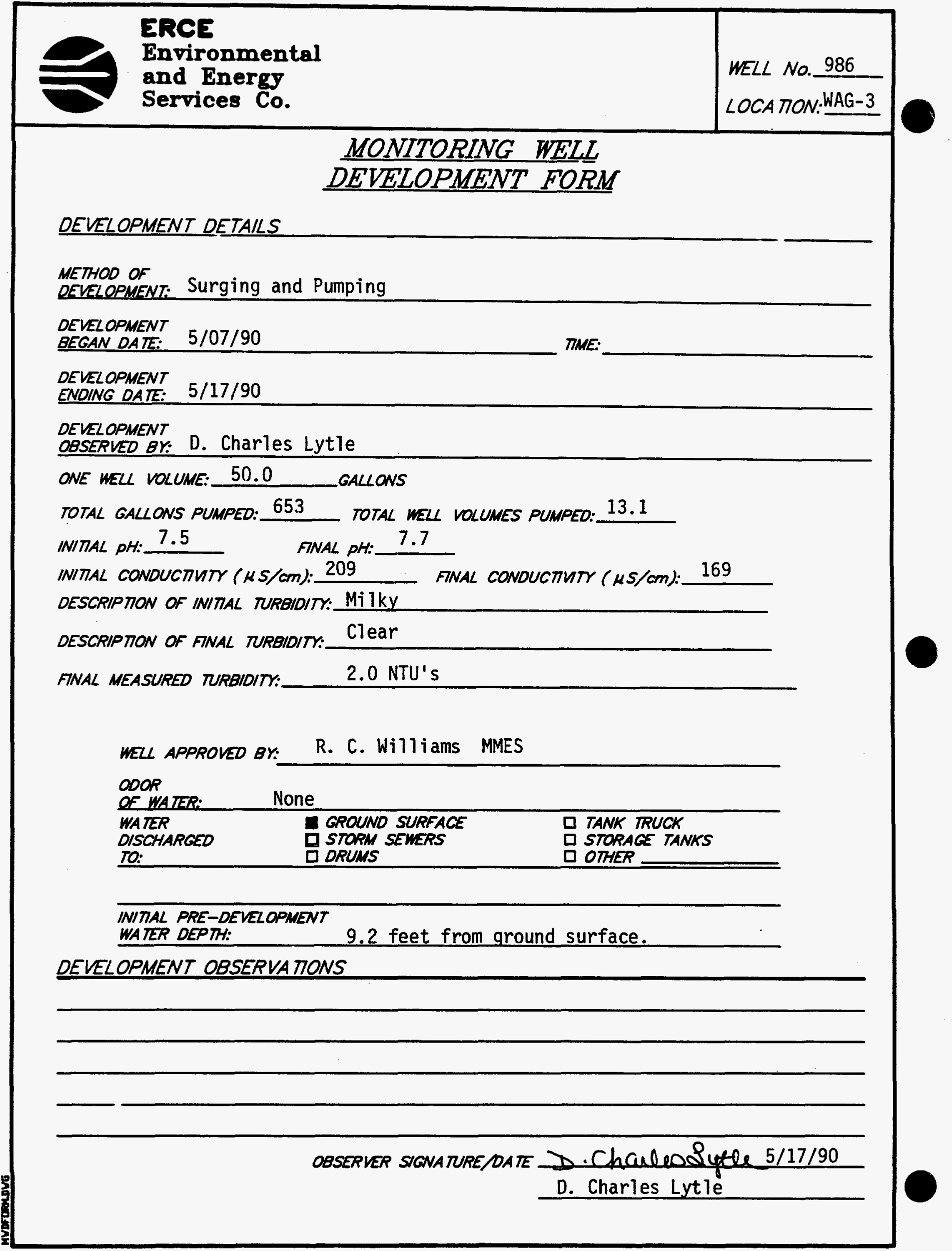




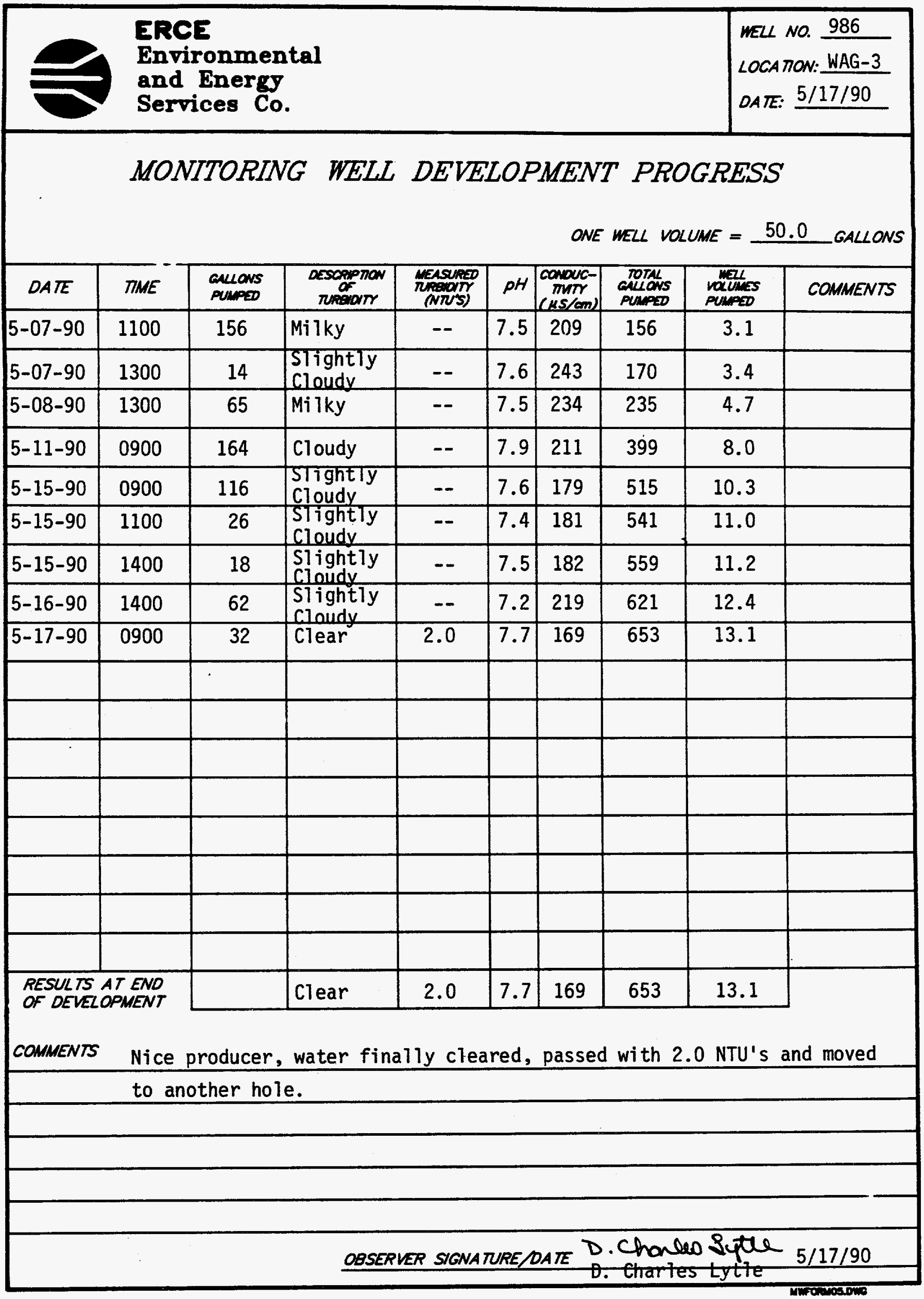




\section{HYORAULIC CONDUCTIVTY CALCULATIONS}

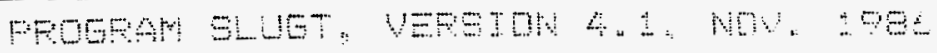

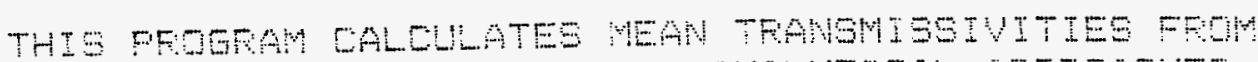

DLUE-TEST DATA EASED WU TWO ANALTMCAL APFDACHES:

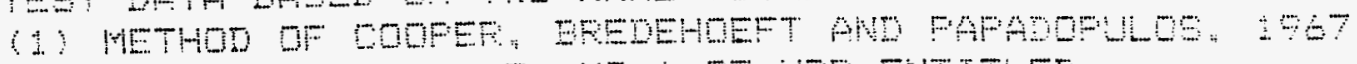
TAOTTLE IN VOL S MO DF WOE ENTTLET

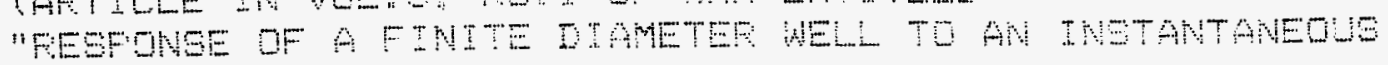
CHAPE TF WATER'

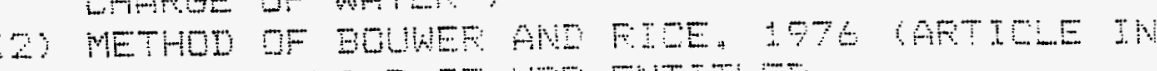

VOL " 2 WO

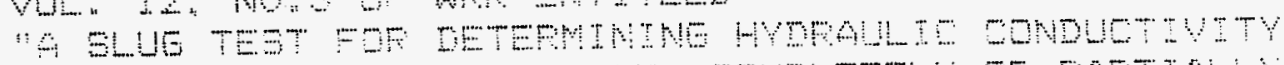

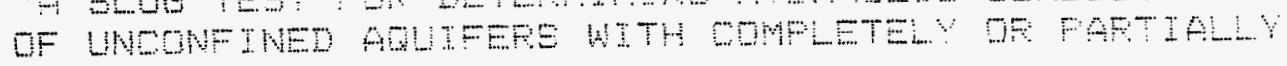

PENETFATRE HEL L":

WEE $\mathrm{NO}: 996$

FOTEOT NO: :-2:-001

SITE LDAPTEN: $x-10$

EDEE, NO. FELD INUESTRGATOE BOUCE MEMASTER
DATE OF TEST: $\quad \triangle 19 \%$

CLIENT: MVES

\section{INEUT DATA AFE:}

THEF CASINS DAAETEF $=2.0 \mathrm{TNCHES}$

INUER SOREEN OF OFEM-HDLE DIAMETEF $=2$ 200 INOHES

DAAMTEF: OF DFILLED HDL = 7.00 TNCHES

LENOTH OF ECFEEN OF INTAE FOFTION $=20.0 \%$ FEET

DEFTH FPOM STATIC LEVEL TO BOTTOM OF SCEEEN = $45.30 \mathrm{FEET}$

THLCNESS OF SATURATED ADUTEF ZONE = $20.00 \mathrm{FEET}$

DEFTH TO STATIC WATEF LEUEL EELOH FEF. FOINT = 94 FEET

EOTMATED POPOSITY OF GEAVL PACA = 30

FALLING-HEAD INDEX = I " "I" IF FALLING "O" TH FISTNS

NUVEEE DE DEFTH-TIME DATA FOINTS =

HO WAE COWFUTED FFOW INTEPCEFT OF FLOT DF LOELH VE. TIME

SUCOESSIVE COHFUTED

VALUES FOR HO

$$
\text { (FEET) }
$$

1.4455

i. 4550 
ERC / EDGE

Environmental

and Energy

WELL NO. 986 Services Co.

\section{HYORAULIC CONDUCTIVTY CALCULATIONS}

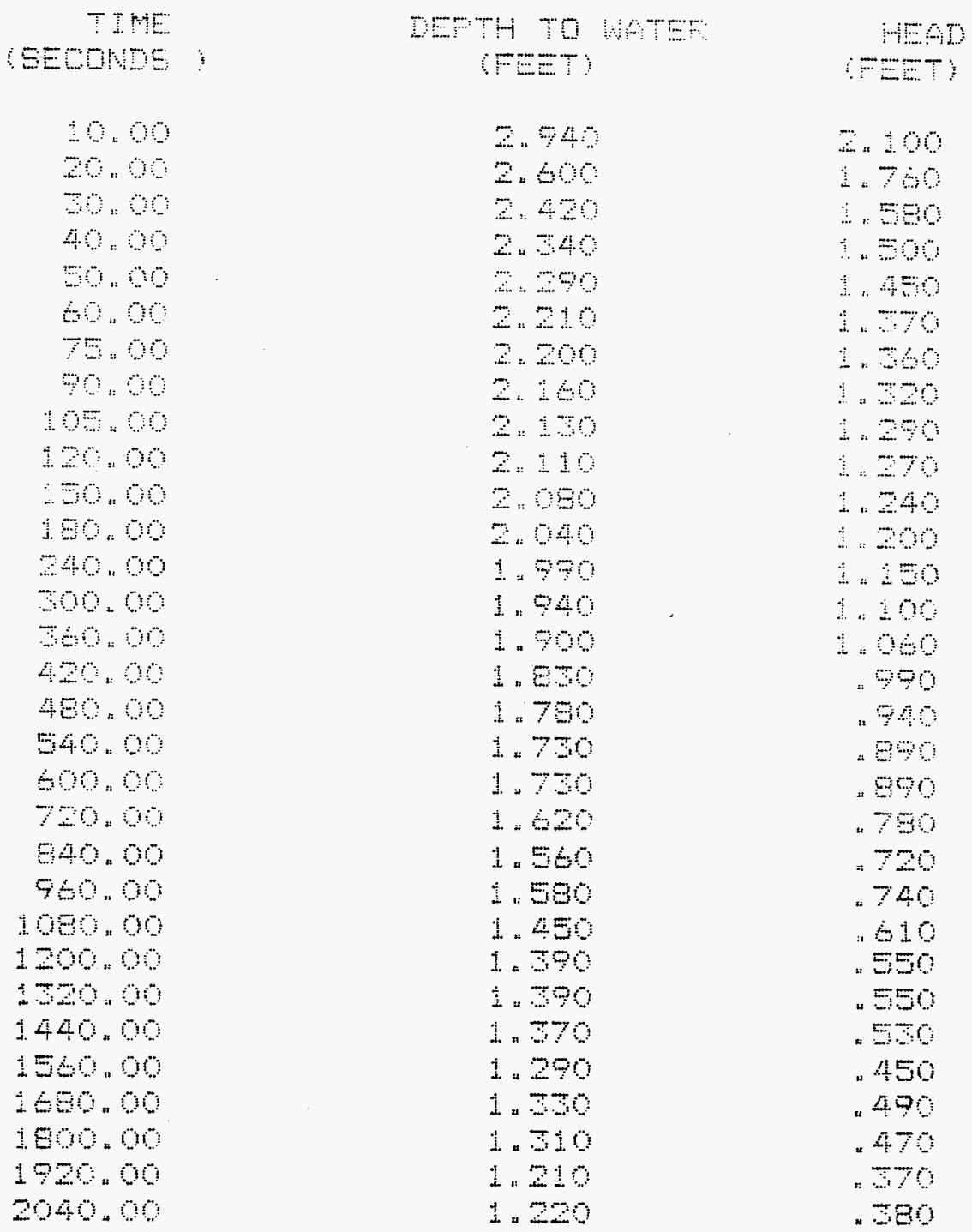

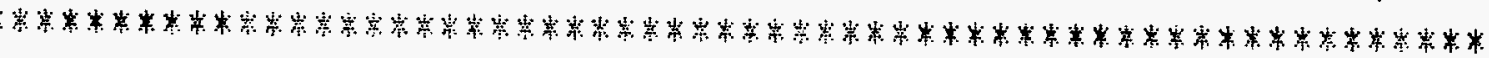

METHOD OF EOLINEF AND FTEE

COMFUTED REMUTS USUNE DIAMETEF OF DFIULE HOEE

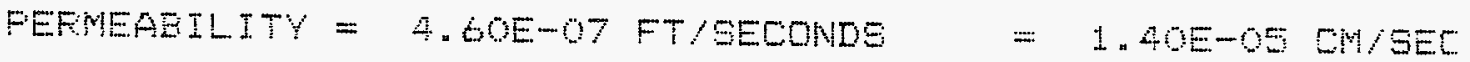

TFANSWISETUITY = 9.2OE-OE FTHZZOEOMUDS 


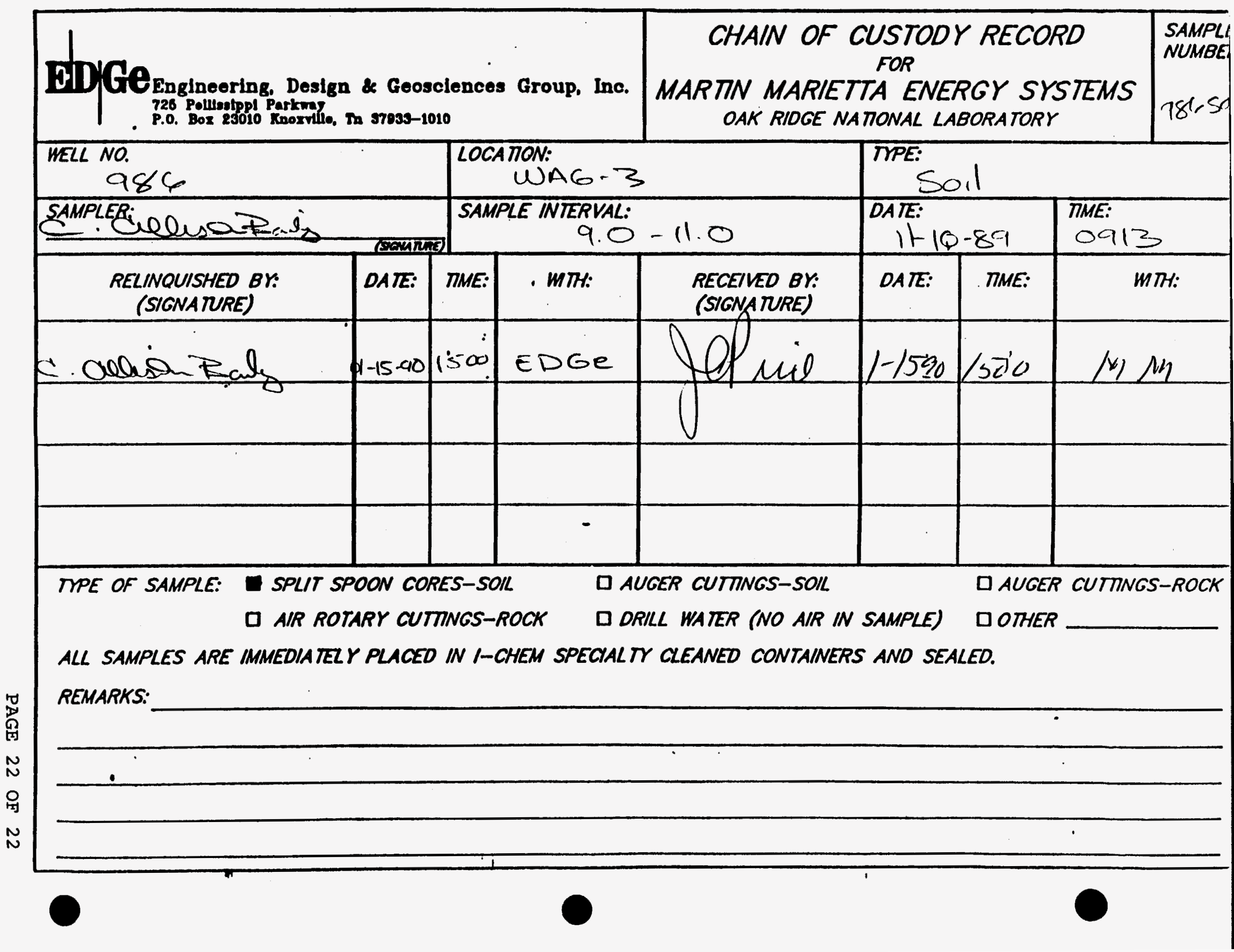


ERC / EDGE

Environmental

and Energy

Services Co.

\subsection{General Information}

\subsection{Ne11 Location}

Monitoring well number 987 is located in WAG 3. It is approximately 250 feet west of the SWSA 3 perimeter fence. The location is shown on ORNL drawing number C3E20004 A075. Survey coordinates for this well are N 21,650.1399, E 25,857,8905 (X-10 grid) or latitude $35^{\circ}-55^{\prime}-04.21^{\prime \prime}$ and longitude $84^{\circ}-19^{\prime}-50.67^{\prime \prime}$. Coordinate data were provided by Martin Marietta Energy Systems. The method used for conversion from $\mathrm{X}-10$ grid to Tennessee-Lambert state Plane Coordinates came from the publication "Tennessee Valley Authority Data Services Branch and Mapping Services Branch, Oak Ridge, Tennessee, DOE Plant Control, November 6, 1985, Field Book: ESS-3115, pp. 1-20." The latitude and longitude were calculated by Adams Craft Herz Walker Engineering, Inc., using methods from the U.S. Coast and Geodetic Survey Publication 62-4, "State Plane Coordinates by Automatic Data Processing."

\subsection{Drilling Information}

Well number 987 was drilled by A. L. Clark Drilling Services, Inc. A Gus Pech and a Schramm rig were used to drill this boring for monitor well installation under operation of A. L. Clark, II and A. L. Clark, III with the assistance of Leo Johnson. Drilling commenced on 11-3-87 and was finished on 11-18-87. Paragraph 2.4.1 includes a detailed discussion of the well installation and a well schematic is included on the well installation/completion form. A synopsis of the drilling activity follows. This information was 
ERC / EDGE

Environmental

and Energy

Services Co.
MONITORING WELL PROGRAM

WEZL OATA NARRATVE

WELL NO. 987

typed directly from field notes and was edited only when necessary for clarification.

11-3-87-11-4-87 The Gus Pech was steamcleaned.

11-5-87 The drill rig was mobilized to the staked location and set up. The boring was drilled from 0.0 ' to 1.4 ' with 14 " augers. The boring was split spooned from 1.4 feet to 9.4 feet.

11-6-87 The boring was split spooned from 9.4 to 13.3 feet, and augered to 14.3 feet with 14 " augers.

11-9-87 Ten-inch surface casing was set from the surface to 14.3 feet and the casing grouted.

11-11-87 The Schramm air rotary was steamcleaned and the boring advanced to a total depth of 48.2 feet.

11-17-87 The well was set with 4-inch stainless steel screen and casing. The sand pack and bentonite seal were installed.

11-18-87 The annular space was tremie grouted.

This well was logged by ERC Environmental and Energy Services Co., Inc., hydrogeologists Michael L. Ebers and Bryn D. Howze. All well construction materials and supplies were from Martin Marietta Energy Systems approved batches. The batch origin of individual items is shown on the included Monitoring Well Materials Certification form. 


\subsection{Technical Information}

\subsection{Decontamination Procedures}

The drilling rig, down hole tools, surface casing, stainless steel screen, stainless steel casing, centralizers, and stainless steel silt trap underwent the cleaning decontamination procedures outlined in the drilling specifications (Release specific Technical Directions for Regulatory Compliance Monitoring Wells Phase 1 , Oak Ridge National Iaboratory, Oak Ridge, w.0. K-4147, April 1987, pgs. 2-4). A checklist of the cleaned materials is included with this data package.

\subsection{Geology}

WAG 3 is located in Melton Valley which is in the Valley and Ridge Physiographic Province of East Tennessee. WAG 3 is underlain by limestone, siltstone and shale of the Middle Ordovician Chickamauga Group. The Chickamauga Group consists of eight units, designated by letters "A" to "H" (Stockdale, 1951). WAG 3 is underlain by units E, F, G and H. These units consist of thin bedded nodular limestone with clay and shale partings. A portion of unit $H$ and unit $F$ consists of calcareous siltstone alternating with beds of olive gray to maroon shale. strike and dip varies from $\mathrm{N} 45^{\circ} \mathrm{E}$ to $\mathrm{N} 55^{\circ} \mathrm{E}$ and $25^{\circ}$ to $35^{\circ}$ southeast, respectively. 


\subsection{Sample collection}

One soil sample and one drill water sample were collected during drilling, placed in an I-CHEM specialty cleaned glass container, sealed and submitted to Sample Receiving, Analytical Chemistry Division, Bldg. 4500S, ORNL. Chain of custody forms for these samples are included with this data package. Soil sample 987501 was collected in the split spoon interval from 2.1 feet to 2.2 feet on 11-5-87.

A drill water sample was collected from the water pump on the drill rig on 11-11-87. Analytical results for the soil and water samples described above can be obtained from the Remedial Action Program data base at ORNL.

\subsection{Installation and Development}

\subsubsection{Installation}

This was a "Type B" well. A 14-inch diameter boring was augered from ground surface to bedrock (14.3 feet). A 10-inch diameter string of decontaminated steel surface casing was installed and tremie grouted in place. The surface casing minimizes potential cross contamination between the regolith and bedrock water bearing zones. The air rotary method was then used to drill an 8-inch diameter boring to a total depth of 48.2 feet. A 4-inch diameter stainless steel silt trap was installed from 47.9 to 48.2 feet. Above 
ERC / EDGE

Environmental

and Energy

Services Co.

the silt trap, a 4-inch diameter stainless steel screen was installed from 27.1 feet and extending 2.12 feet above ground surface. A sandpack was then poured into the annular space from 25.4 to 48.2 feet, with a 2.3-foot bentonite seal poured into the annular space above the sandpack from 23.1 to 25.4 feet. The annular space from the top of the bentonite seal to the surface was tremie grouted with a cement/bentonite slurry. A detailed schematic of the well is included on the well installation/completion form.

\subsubsection{We11 Development}

Well number 987 was developed to remove drill cuttings, silt, and other fines. The monitoring well was developed using a Geoguard pump with an air compressor. All pumps were cleaned prior to use according to specified cleaning procedures (see Paragraph 2.1). The well was developed until a measured total of 404 gallons of water had been evacuated and the clarity of the discharge water was approved by the company representative. The final turbidity value measured at completion was $>100 \mathrm{NTU}$ 's. A development form showing the exact method of development and other pertinent data is appended.

2.4.3 Installation of Dedicated Monitoring well Pump

After the well was developed, a Geoguard Model No. 5614 dedicated monitoring well pump was installed 
on 5-4-90 at a depth of 45.7 feet below ground surface. These pumps are decontaminated at American sigma and are sent prepackaged. A copy of the pump certification is kept on file at ORNL.

\subsection{Hydraulic Conductivity Testing}

Well number 987 was tested for the determination of hydraulic conductivity of the aquifer in the vicinity of the well screen. This was accomplished by instantaneously adding a known quantity of water to the monitoring well and measuring the recovery of the water level over time. The changing water levels were measured using a Druck $15 \mathrm{psig}$ pressure transducer and an Omnidata Datapod II data recorder. The hydraulic conductivity value of $4.97 \times 10^{-5} \mathrm{~cm} / \mathrm{second}$ (shown as permeability on the hydraulic conductivity calculations printout attached) was calculated using the Bouwer and Rice method. A computer printout of the hydraulic conductivity calculations is included in this data package. 
ERC / EDGE

Environmental

and Energy

WELL No. 987

\section{PRE-DRILLING CHECKLIST FOR MONITORING WELLS}

PRE-DRILLING TASKS

1. EXCAVATION PERMIT OBTAINED.

2. ALL EQUIPMENT HAS BEEN CLEANED BEFORE DRILLNG.

30. SCREEN AND CASINGS HAVE BEEN WASHED, STEAMED, RINSED WTH DE-IONIZED OR DISTLLED WATER, RINSED WTH ISOPROPY ALCOHOL WRAPPED WTH PROTECTIV COVERING AND STORED OFF THE GROUND.

36. PRE-PACKAGEO SCREENS, CASINGS AND CENTRALIZERS IIERE USED.

4. MORK AREA FOR SAMPLE EXAMINATION COVERED MTH CLEAN POL YETHYLENE.

5. CLEAN KNIVES, GLOVES, SAMPLE JARS AND LABELS ON-HAND.

6. POL VETHILENE COVER IN PLACE OVER HOLE. AODIMONAL NOTES/OBSERVATONS:
COMPLIANCE

DATE INITALS

$\frac{11-05-87}{11-05-87} \frac{\mu \omega}{\mu L}$

$N / A$

11-17-87 BDH

11-06-87 use

11-05-87 ME

11-05-87 ME

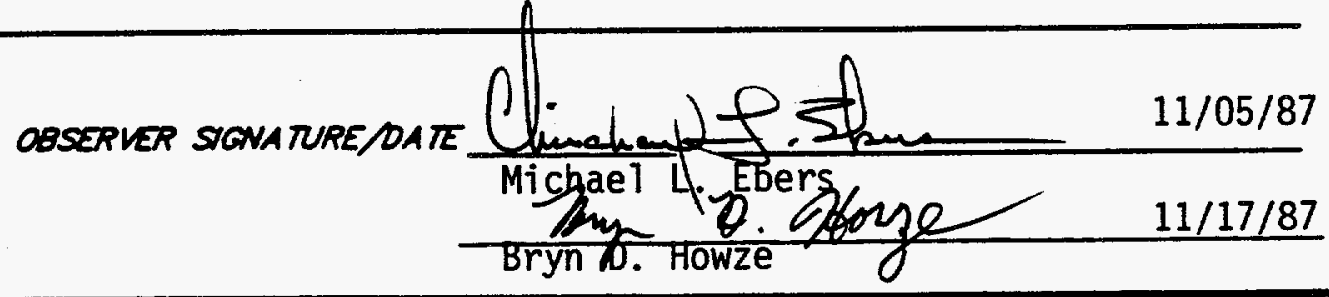


DECONTAMINATION CHECKLIST

DRILLING EQUIPMENT

\begin{tabular}{|c|c|c|c|c|c|}
\hline EQUIPMENT & SCRAPE & $\begin{array}{l}\text { STEAN } \\
\text { CLEAN }\end{array}$ & $\begin{array}{l}\text { STEAM } \\
\text { RINSE }\end{array}$ & $\begin{array}{c}\text { ISOPROPY } \\
\text { ALCOHOL } \\
\text { RINSE }\end{array}$ & $\begin{array}{c}\text { OEIONIZED } \\
\text { WATER } \\
\text { RINSE }\end{array}$ \\
\hline$R / G$ & $X$ & $x$ & $x$ & $N / A$ & $N / A$ \\
\hline AUGERS & $x$ & $x$ & $x$ & $x$ & $x$ \\
\hline BITS & $x$ & $x$ & $x$ & $x$ & $x$ \\
\hline ROOS & $x$ & $x$ & $x$ & $x$ & $x$ \\
\hline SAMPLERS & $x$ & $x$ & $x$ & $x$ & $X$ \\
\hline PIPES & $x$ & $x$ & $x$ & $x$ & $x$ \\
\hline WORK TOOLS & $x$ & $x$ & $x$ & $x$ & $x$ \\
\hline AUGER PINS & $x$ & $X$ & $x$ & $x$ & $x$ \\
\hline & & & & & \\
\hline & & & & & \\
\hline & & & & & \\
\hline & & & & & \\
\hline
\end{tabular}

OBSERVER SIGNATURE/OATE Dhuahan. She 11/05/87 


\begin{tabular}{l} 
ORNL MONITORING WELL LOG \\
\hline LOCAMON: SWSA 3 \\
DRILLER: A.L. Clark, III/A.L. Clark, II \\
HELPER: Danny Julian/Leo Johnson \\
DR/LL: GUS Pech and Schramm Air Rotary
\end{tabular}

TPE ORILING: Auger and Air Rotary

No. SAMPLES TAKEN: 2 (two)

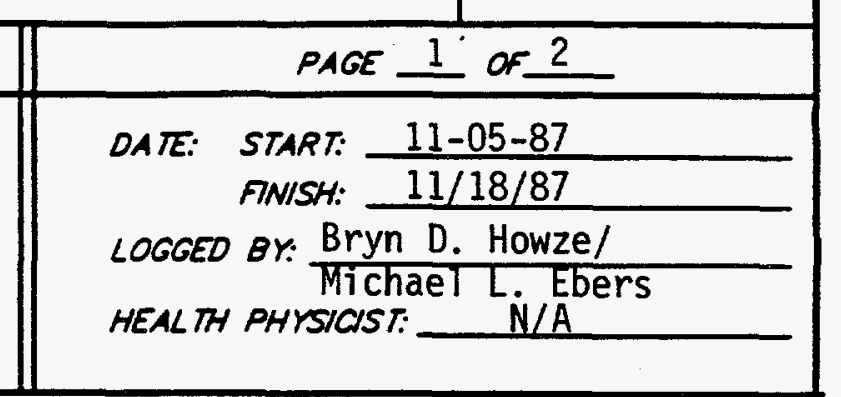

LUBRICANT TPE: Green stuff TPE: 1 soil/1 water

CONTAINUENT TrPE: Auger Pan, Plastic, Containment Box

THICKNESS OF SOLL (REFUSAL DEPTH): 13.3'

OEPTH DRILLED IN ROCK: $34.9^{\prime}$

TOTAL OEPTH OF WELL: 48.2
DRIUNG FLUID SAMPLES:

TPE: Water DATE: $11 / 11 / 87$

\begin{tabular}{|c|c|c|c|c|}
\hline \multicolumn{2}{|c|}{ 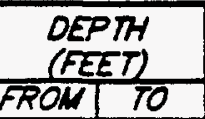 } & \multirow[t]{2}{*}{$\begin{array}{l}\text { SANPLE } \\
\text { (NUMBER } \\
\text { NTIERVAL) }\end{array}$} & $\begin{array}{c}\text { PERCENT } \\
\text { RECOVERY } \\
\text { (SPUT SPOONS) }\end{array}$ & \multirow[t]{2}{*}{ SOLL/BEDROCK DESCRIPTION } \\
\hline 0.0 & 0.2 & & 14" Auger & \\
\hline \multirow[t]{3}{*}{0.2} & 1.4 & & 14" Auger & Clay, light to moderate brown, slightly silty, \\
\hline & & & & medium dense, damp, medium soft-plastic, \\
\hline & & & & abundant tree roots. \\
\hline \multirow[t]{2}{*}{1.4} & 2.1 & & $100 \%$ & Clay, moderate reddish brown, silty, few roots \\
\hline & & & & and fine chert gravels, damp. \\
\hline \multirow[t]{3}{*}{2.1} & 9.4 & 0987501 & $100 \%$ & Clay, distinctly mottled, moderate reddish \\
\hline & & $02.1-2.2^{\prime}$ & & brown and yellowish orange, fine silty, \\
\hline & & & & medium stiff, slightly damp, few roots. \\
\hline \multirow[t]{2}{*}{9.4} & 9.8 & & $100 \%$ & Clay, silty, reddish brown, mottled, orange, \\
\hline & & & & yellow, black, minor roots, stiff. \\
\hline \multirow[t]{3}{*}{9.8} & 11.4 & & $100 \%$ & Silt, clayey, highly weathered shaley limestone, \\
\hline & & & & light brown, mottled orange, black, greenish \\
\hline & & & & gray, firm to stiff. \\
\hline \multirow[t]{5}{*}{11.4} & 13.3 & & $100 \%$ & Silt, slightly clayey, highly weathered shaley \\
\hline & & & & limestone, light brown, mottled orange black, \\
\hline & & & & greenish gray, with relict bedding, damp, \\
\hline & & & & stiff. \\
\hline & & & & Split spoon refusal at $13.3^{\prime}$. \\
\hline 13.3 & 14.3 & & & Limestone, weathered, light gray. \\
\hline 14.3 & 48.2 & & & No detailed lithologic description available \\
\hline
\end{tabular}

PAGE 9 of 20. 


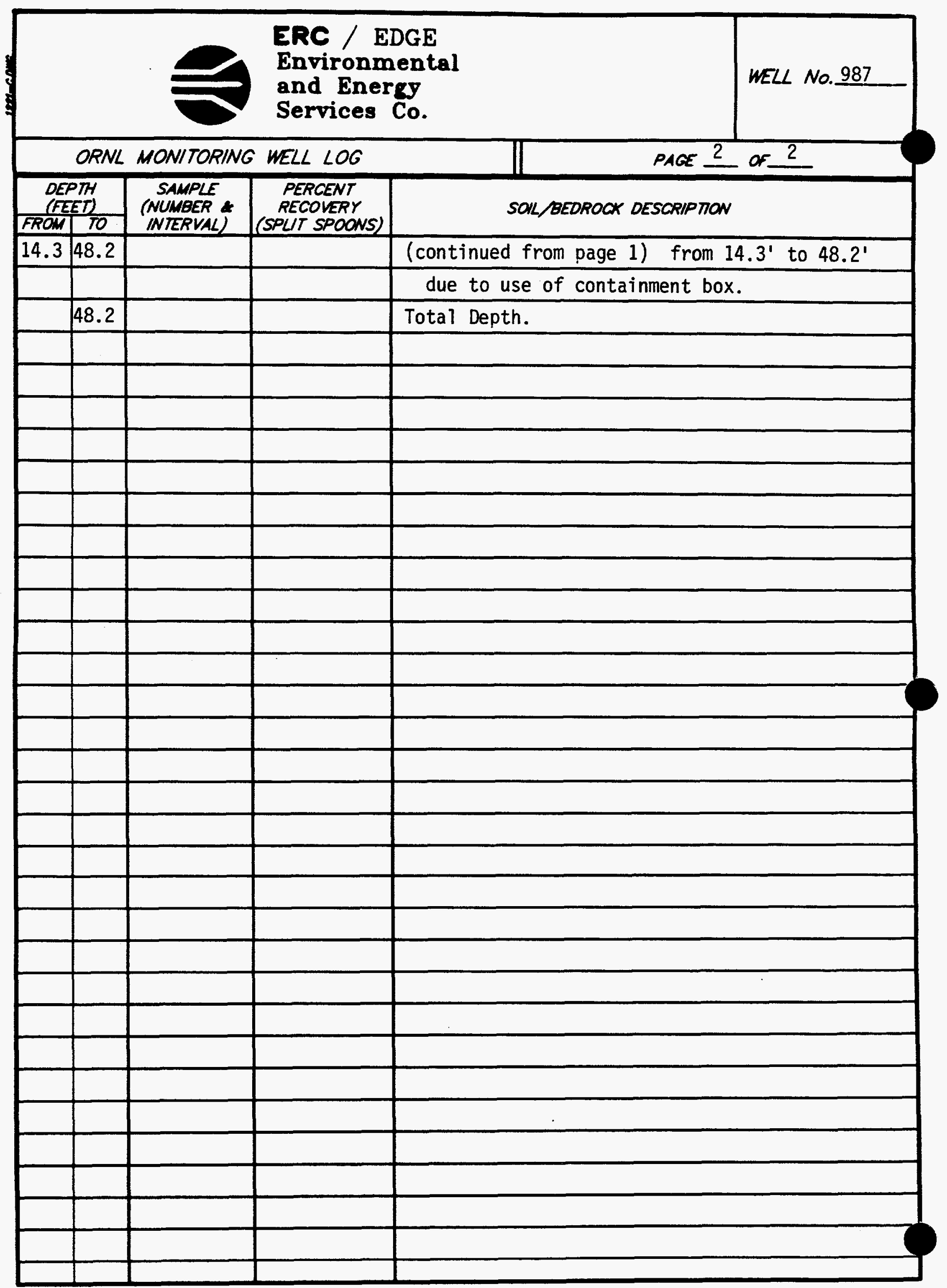

PAGE 10 of 20 
WELL INSTALLATION/COMPLETION FORM

LOCGed Michael L. Ebers /

O.R.N.L. MONITORING WELL PROGRAM

BY:

Bryn Howze

PROOFED

BX. Michael L. Ebers

ORILUNG COMPANY.

A. L. Clark

ORUER: Avery L. Clark, III HEZER: Leo Johnson

DAILUNG METHOD: D 14 INCH AUCER 14.3 LF.

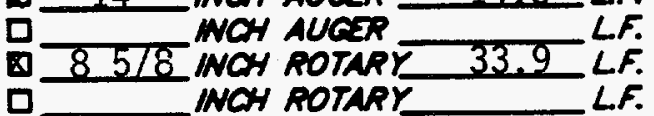

MATERIALS USED

EST. 4520

vai va

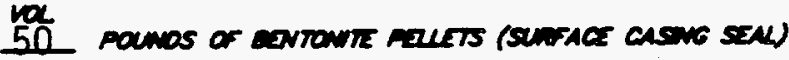

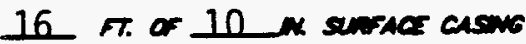

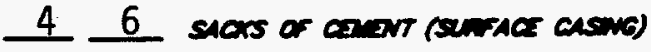

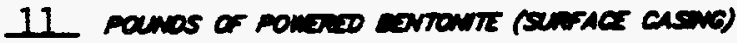

36 aveous of mine (sensice caswa)

30.0 r. of $4 \mathrm{ne}$ on staness ster casevo

$20.8 \pi$ or $4 \mathrm{~m}$ an sturess ster senerv

$7.4 \frac{8}{210 x s}$ or suo

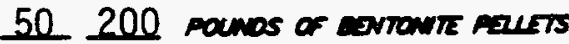

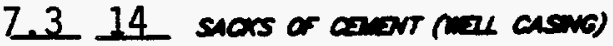

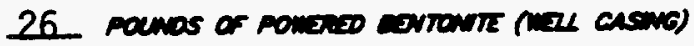

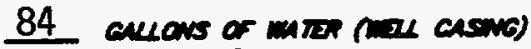

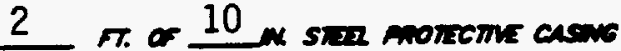

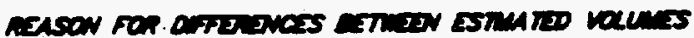

wo usid vauness

Cavities and fractures.

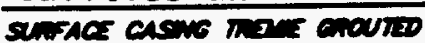

stamerss stras casmis

inser anoutis

$$
\text { al COND UND }
$$

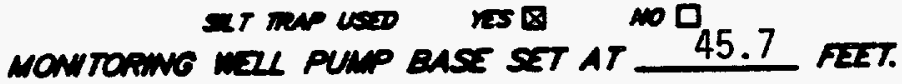

Cs

nst

Nos m

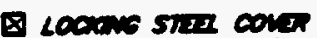

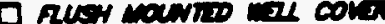
orins

CENTRALITS AT

$\begin{array}{r}3.0 \\ \hline 12.0 \\ \hline 27.0 \\ \hline 48.0\end{array}$

FEST.

FET.

FET.

FEET

NOTE

ALL DJPTHS ARE MEASURED

FFOW GPOUN SUNFACE

UNEESS OTHERIMSE NOTED:

TYPE $B$ WELL

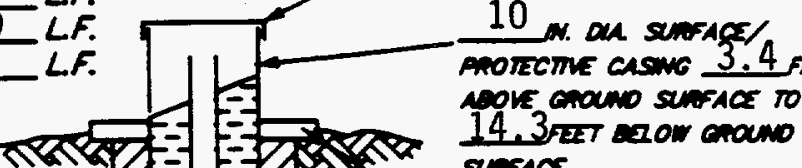

14.3 fres arow anowo

surace

CONGETE PAD

14 w. an mare Has

$0.0 \pi 14.3$ न्या

engur ses 0.0 ro

130 का

4 a stancess star casivo 29 ADT Move Gano suriar to 271 FEET azow anouno surface

Bentonite sen 13.0 ro 14.3 .2IT

areax $4 \mathrm{rrz} 14.3$

$85 / 8 x$ an war mat

Gourses 0.0 ro

23.1 म제

osvinutase

Gyrame erued sou

$23.1 \pi 25.4$ नख्य

smo prox 25.4 ro

48.2 F्य

$2 x$ an stamess stas serigo sanss 27110 47.9 Fas

2 an an stamess stog sт meren 47.9 ro 48.2 न्या 


\section{MONITORING WELL MATERIALS CERTIFICATION}

\begin{tabular}{|c|c|c|}
\hline ITEM $/ M A$ TERIAL & DAIE USED & BATCH NUMBER \\
\hline \multirow{2}{*}{ SAND } & $11-09-87$ & 2 \\
\hline & $11-17-87$ & 3 \\
\hline \multirow{2}{*}{ BENTONITE } & $11-09-87$ & 3 \\
\hline & $11-17-87$ & 3 \\
\hline (PREPACKACED D $\mathrm{YES}$ ) & $11-17-87$ & 5 \\
\hline STAINLESS STEEL CASING (PREPACKAGED 1 TES & $11-17-87$ & 5 \\
\hline STAINLESS STEEL CENTRALIZERS (PREPACKAGED D NOS) & $11-17-87$ & 5 \\
\hline $\begin{array}{llll}\text { STAINLESS STEEL CAPS } & \text { (PREPACKAGED } & \text { YES } \\
\text { NO }\end{array}$ & $11-17-87$ & 5 \\
\hline MONITORING WELL PUMP (PREPACKAGED I NES) & $5-04-90$ & 5 \\
\hline \multirow{2}{*}{ GROUT } & $11-09-87$ & 14 \\
\hline & $11-18-87$ & 14 \\
\hline \multicolumn{3}{|l|}{ WELL COVERS } \\
\hline SURFACE CASING & $11-09-87$ & 2 \\
\hline
\end{tabular}

COMMENTS:

OBSERVER SIGNATUREDATE $\frac{\text { Byy P. PoYge 11-17-87 }}{\text { Bryn B. HowZe }}$ 


\section{POST-MELL COMPLETION CHECKLIST}

\section{POST-WELL COMPLETION TASKS}

$$
\begin{aligned}
& \text { COMPLIANCE } \\
& \text { DA.TE INITIALS }
\end{aligned}
$$

1. WUD SCRAPED FROW AUEERS SAMPLERS ANO ALL

$11 / 18 / 87$ OTHER EQUIPNENT.

2. NLL WUO FRON RTE ANO EQUPMENT SCRAPWOS ANO CUTINOS DISPOSED OF WN ACCORDANCE WIT IHF SPECATCA nON PROWOED.

3. WEL OEVELOED IN ACCORDANCE WIH THE SPECATCA TON PROVDED ANO DETAKS OF THE DEVEZ OPUENT ACTITH RECOROED.

4. DRULWG STE PROPERLY CLEANED UP ATTRR cowpletion of WIL INSTALLA now.

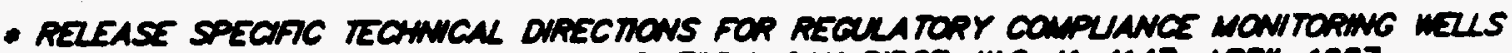
PHASE i, OAK RHOCE NATONAL LABORATOPY, OAK RDOC: Ma K-4147. APRK 1987.

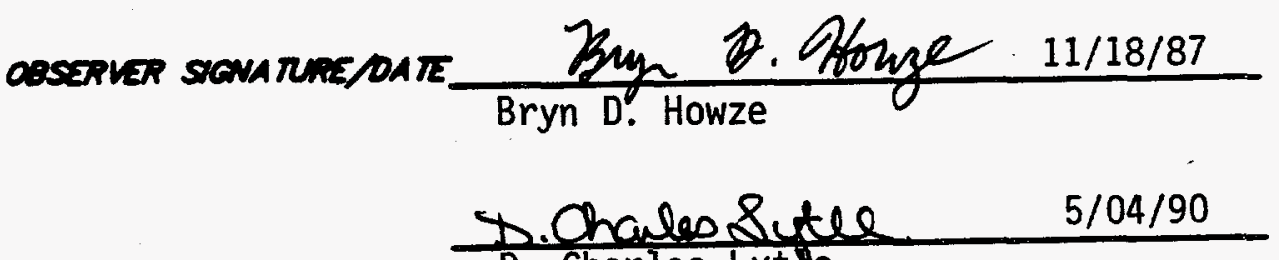

D. Charles Lyt Pe 


\section{MONITORING WELL DEVELOPMENT FORM}

DEVELOPMENT DETA/LS

METHOD OF

DEVELOPMENT: Surging and Pumping

OEVELOPMENT BEGAN DATE:

$$
4 / 27 / 90
$$
TME:

DEVELOPMENT ENDING DATE:

$$
5 / 04 / 90
$$

DEVELOPMENT

OQSERVED BY: D. Charles Lytle

$$
\text { ONE WELL VOLUME: } 13.0 \text { GALLONS }
$$

TOTAL GALLONS PUMPED: 404 TOTAL WELL VOLUMES PUMPED: 31.1

INITAL PH: 7.7 FNAL PH: 7.6

INITAL CONDUCTUTY ( $\mathrm{s} / \mathrm{cm}): 674$ FINAL CONDUCTVTY $(\mu \mathrm{S} / \mathrm{cm}): 651$

DESCRIPTION OF INITAL TURBIOITY: ClOUdY

DESCRIPTION OF FINAL TURBIOITY: Milky

FNAL MEASURED TURBIDITY_G Greater than 100 NTU'S

WEL APPROVED BY. R. C. WIIl I AMS MMES

ODOR

QF WATER: None

WATER

DISCHARGED

TO:

Q GROUND SURFACE
STORM SEWERS

O STORM SEWERS

D TANK TRUCK

D DRUNS

口 STORAGE TANKS

口 OTHER

INITAL PRE-DEVELOPMENT WATER DEPTH:

23.5 feet from ground surface.

\section{DEVELOPMENT OBSERVATIONS}

OBSERVER SIGNATURE/DATE D. Chalooslytele 5/04/90 D. Charles Lytle 


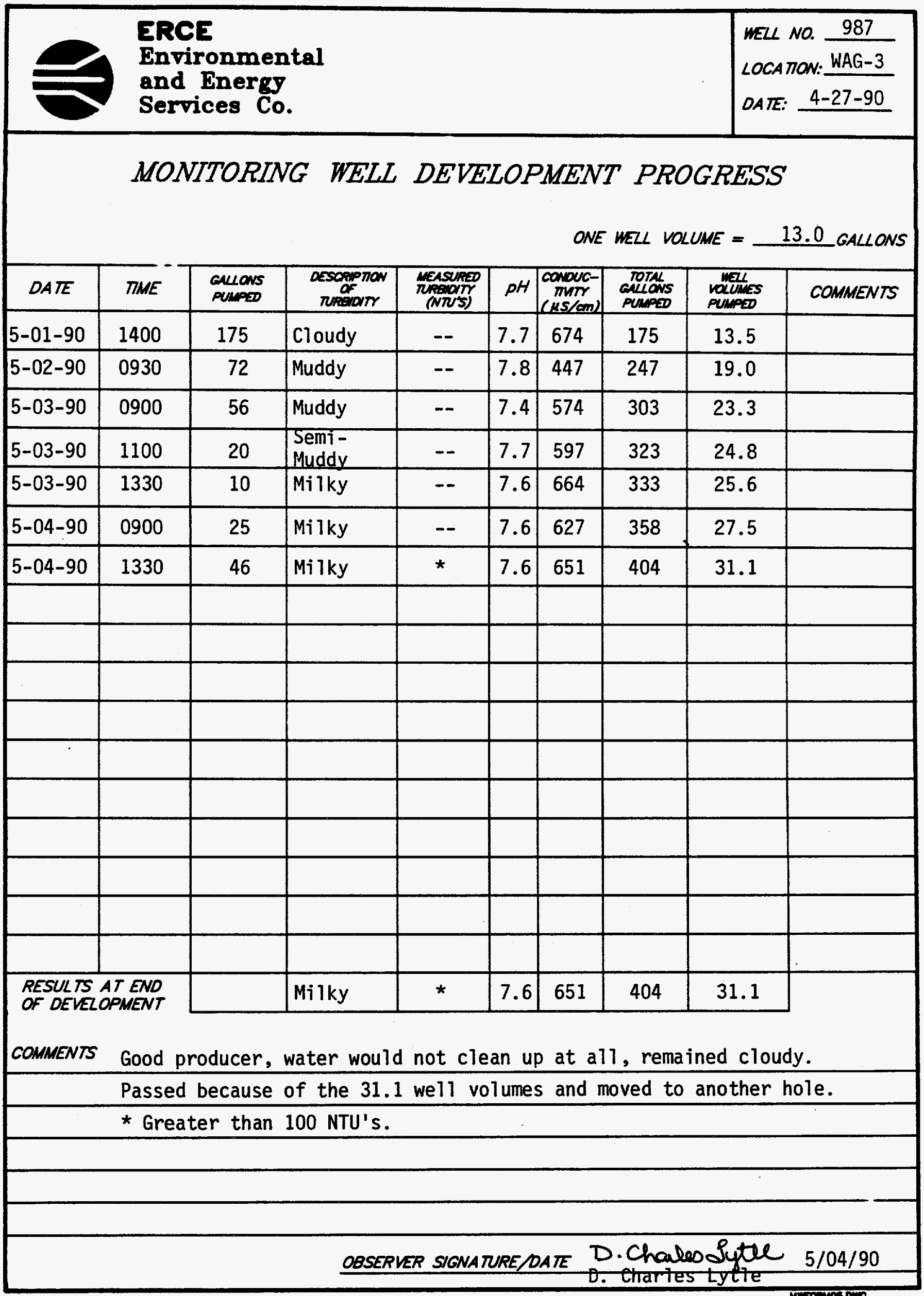

PAGE 15 of 20 . 


\title{
HYORAULIC CONDUCTIVTY CALCULATIONS
}

\author{
FFOGFAM SLUGT, VEFEIOH 4.1, NOY 1980
}

THIS PFOGFAM CALCULATES MEAN TFANGMISEIUITIES FFOM SLUG-TEST DATA BASED ON TWO ANALYTICAL APPROACHES:

(1) METHOD OE COOFEF, EFEDEHOEFT AND FAFADOPULOS 1967 CAFTICLE IN VOL. 3 , NO. 1 OF WFF ENTITLED

"PESFOUSE DF A FINTTE DIANETEF WELL TO AN INSTANTANEDUS CHAFEE OF WATEF" :

(2) METHOD OF BOUWEF AND FICE, 1976 (AATICLE IN YOL. 12, NQ. 3 OF WFF ENTITLED

"A SLUS TEST FOF DETEFMINING HYDFAULIS DONDUCTIUITY OF UNCONFINED AOUIFEFS WTTH COMPLETELY OFE FARTIALLY FENETRAT ING WELLS")

WEILL NO: 0987 DATE OF TEST: $5 / 16 / 90$

FFOJECT NO: E221-DO2 CIIENT: MHES

SITE LOGATION: WAG-S

EDGE; INC: FIELD INVESTIGATOF: BruEe MEMaster

INPUT DATA AFE:

INNEF: CASING DIAMETEF: = 4. DO INCHES

INMEF SCFEEN OF OPEN-HOLE DIAMETEF: =

DIAMETEF OF DFILLED HOLE $=0.6 \Xi$ INCHES

LENGTH OF SCREEN OF INTAKE FOFTION $=20.50 \mathrm{FEET}$

DEFTH FFOM STATIC LEVEL TO BOTTOM OF SCFEEN = 17.60 FEET

THICKNESS DF SATURATED AOUIFEF ZONE $=20.50$ FEET

DEFTH TO STATIC WATEF LEVEL EELOW FEF. FOINT $=$. DD FEET

ESTIMATED FDROSITY DF GFAVEL PACK = 20

FALL ING-HEAD INDEX $=1$ ("1" IF FALLINE, "Q" IF FISING)

NUMEEF DF DEFTH-TIME DATA FOINTS = 32

HO WAS COMFITED FFOM INTERCEFT OF FLOT OF LQG

SLICCESSIVE COMFUTED

VALUES FOFI HD

(FEET)

1. 7612

1. 7741 


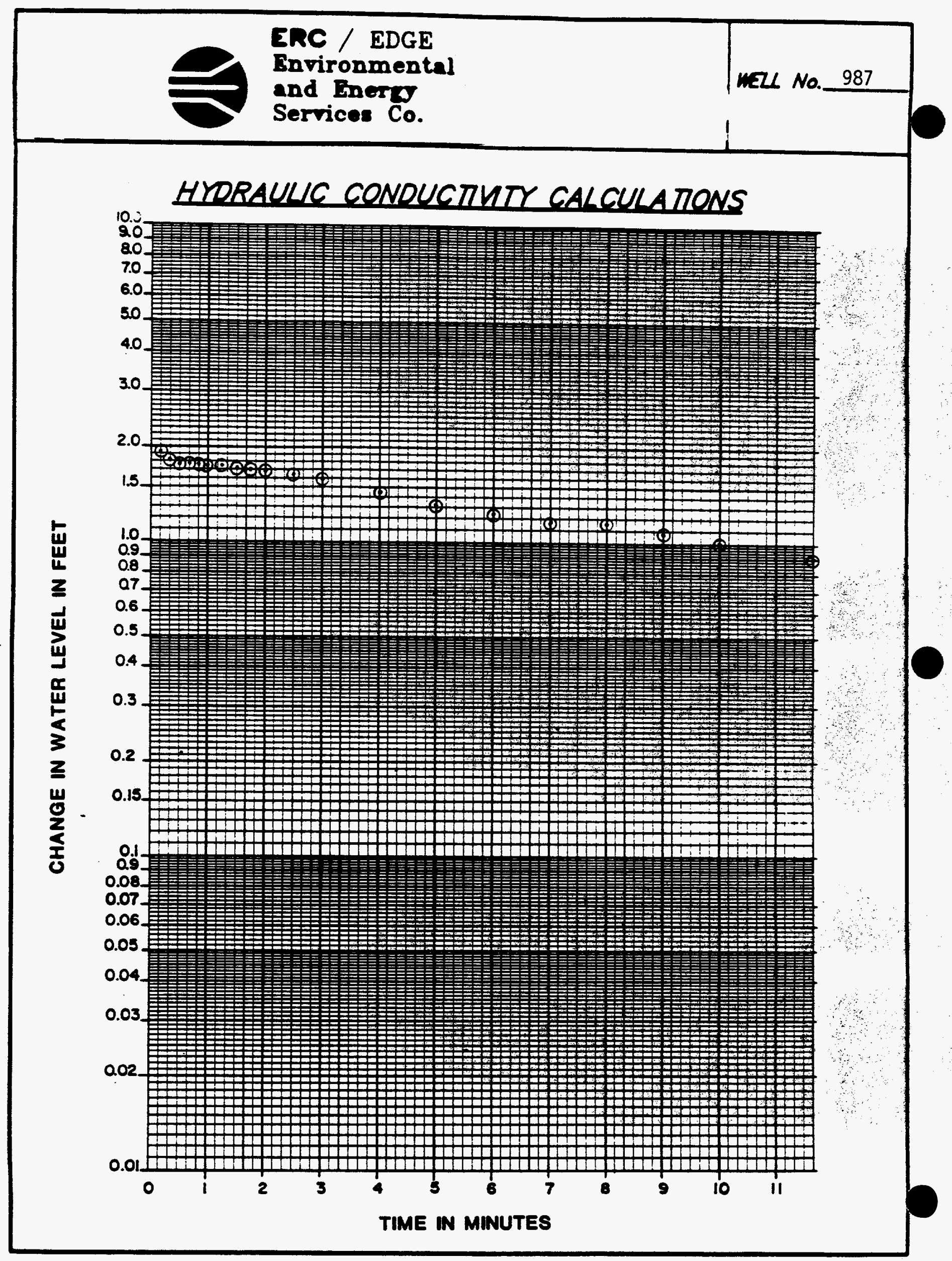

PACE 18 of 20 


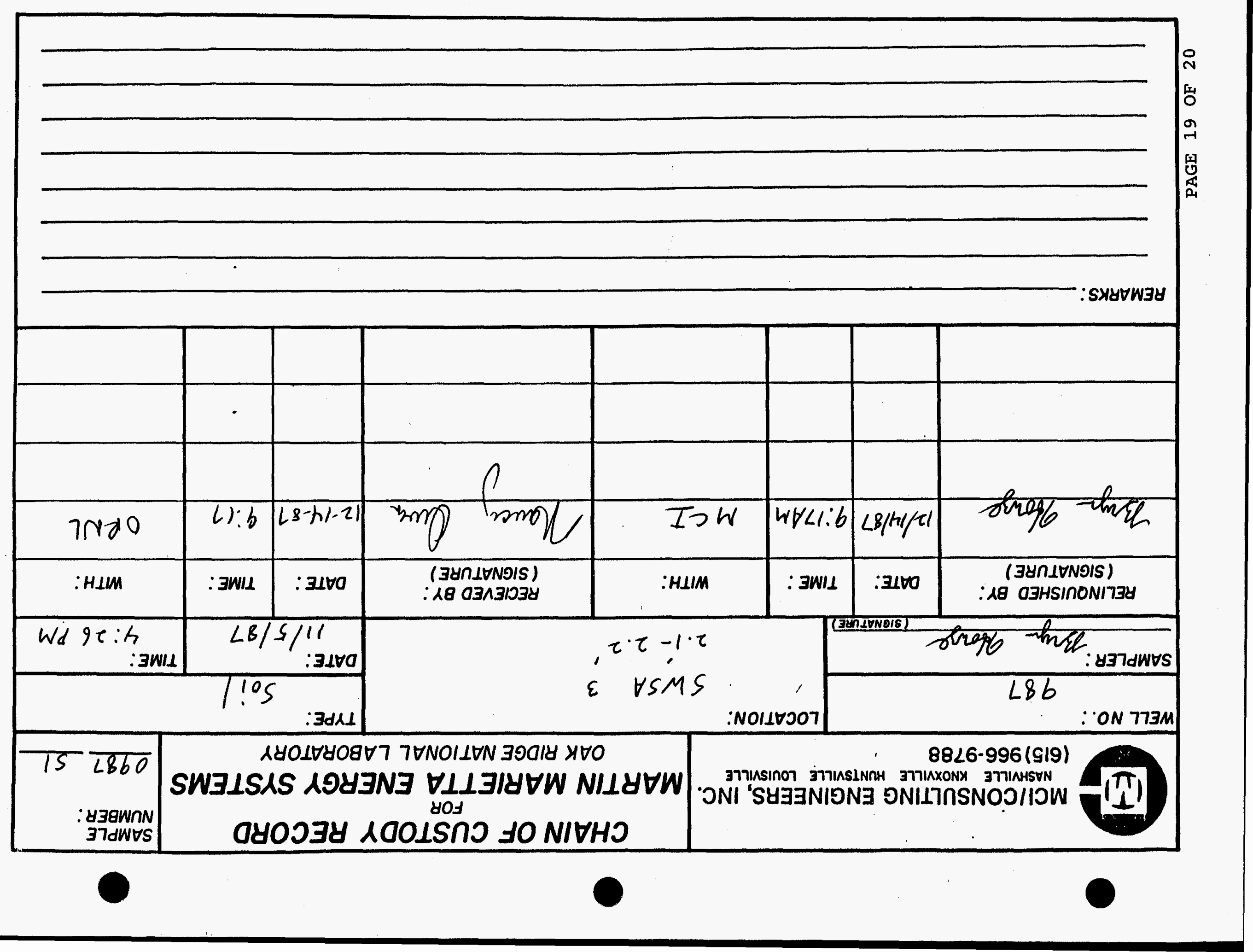




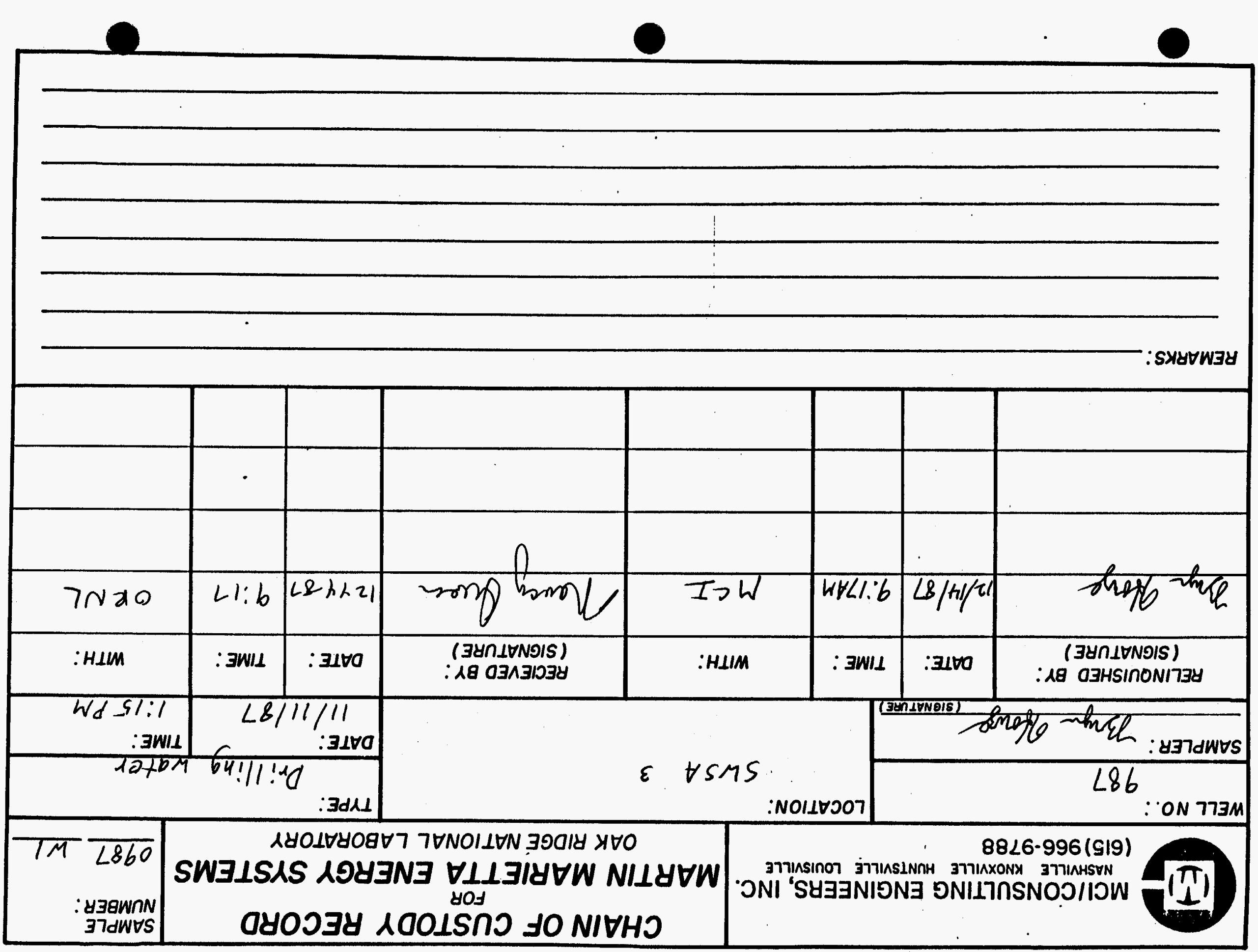


ERC / EDGE

Environmental

and Energy

Services Co.

General Information

\subsection{Well Location}

Monitoring well number 988 is located in WAG 3 . It is located in the southeastern corner of the contractors landfill. The location is shown on ORNL drawing number C3E20004 A075. Survey coordinates for this well are $N 21,075.7290$, E 25,471.2850 (X-10 grid) or latitude $35^{\circ}-54^{\prime}-57.37^{\prime \prime}$ and longitude $84^{\circ}-19^{\prime}-50.69^{\prime \prime}$. Coordinate data were provided by Martin Marietta Energy Systems. The method used for conversion from $\mathrm{X}-10$ grid to Tennessee-Lambert State Plane Coordinates came from the publication "Tennessee Valley Authority Data Services Branch and Mapping Services Branch, Oak Ridge, Tennessee, DOE Plant Control, November 6, 1985, Field Book: ESS-3115, pp. 1-20." The latitude and longitude were calculated by Adams Craft Herz Walker Engineering, Inc., using methods from the U.S. Coast and Geodetic Survey Publication 62-4, "State Plane Coordinates by Automatic Data Processing."

\subsection{Drilling Information}

Well number 988 was drilled by A. L. Clark Drilling Services, Inc. A Gus Pech rig was used to drill this boring for monitor well installation under operation of A. L. Clark III with the assistance of Leo Johnson. Drilling commenced on 9-28-87 and was finished on 11-2-87. Paragraph 2.4.1 includes a detailed discussion of the well installation and a well schematic is included on the well installation/ completion form. A synopsis of the drilling activity 
follows. This information was typed directly from field notes and was edited only when necessary for clarification.

9-28-87 Set up and started drilling - split spoons, then augering.

9-29-87 Augering.

9-30-87 Augered to 39.0' and started bailing.

10-1-87 Drilled/augered to $46.6^{\prime}$ with $63 / 4^{\prime \prime}$ augers and started bailing.

10-2-87 Bailing.

10-5-87 Bailing.

10-6-87 Decision made by Martin Marietta to convert hole from $A$ to $D$.

10-7-87 Augered to 20.0' with $14^{\prime \prime}$ auger.

10-8-87 Set 8" surface casing to 20.0 '.

10-9-87-10-20-87 Modifying fittings to Gus Pech and containment boxes, moving to new staging area.

10-20-87-10-21-87 steam cleaning rods, bit, tooling for air rotary (at SWSA 5 shed); took tooling to Gus Pech.

10-22-87 Took head off rig to check seals.

10-23-87 Replaced seals, put head back on rig.

10-26-87 Drilled w/air to 60.0', checked recovery.

10-27-87 Drilled w/air to 80.0', checked recovery.

10-28-87 Drilled w/air to 100.0', checked recovery.

10-29-87 Grouted from 100.0' to 53'.

10-30-87 Circulated hole w/water to clean out any possible grout in screened interval, added bentonite $47.5^{\prime}$ in afternoon, pulled rig off, cleaned up. 
ERC / EDGE

Environmental

and Energy

Services Co.

11-2-87 Added $1 / 2$ bag sand onto top of bentonite filled up to $46^{\prime}$, could not set well due to lack of bottom cap.

$11 / 5 / 87$ set well and put sand into well, brought sand up to $\wedge 30.0^{\prime}$.

11-6-87 Put sand and bentonite in well.

11-9-87 Grouted up to surface.

This well was logged by ERC Environmental and Energy Services Co., Inc., hydrogeologist Bryn D. Howze. All well construction materials and supplies were from Martin Marietta Energy Systems approved batches. The batch origin of individual items is shown on the included Monitoring Well Materials Certification form.

\subsection{Technical Information}

\subsection{Decontamination Procedures}

The drilling rig, down hole tools, surface casing, stainless steel screen, stainless steel casing, centralizers, and stainless steel silt trap underwent the cleaning decontamination procedures outlined in the drilling specifications (Release specific Technical Directions for Regulatory Compliance Monitoring Wells Phase 1, Oak Ridge National Laboratory, Oak Ridge, w.0. K-4147, April 1987, pgs. 2-4). A checklist of the cleaned materials is included with this data package. 


\subsection{Geology}

WAG 3 is located in Melton Valley which is in the Valley and Ridge Physiographic Province of East Tennessee. WAG 3 is underlain by limestone, siltstone and shale of the Middle ordovician Chickamauga Group. The Chickamauga Group consists of eight units, designated by letters "A" to "H" (Stockdale, 1951). WAG 3 is underlain by units E, F, G and H. These units consist of thin bedded nodular limestone with clay and shale partings. A portion of unit $H$ and unit F consists of calcareous siltstone alternating with beds of olive gray to maroon shale. strike and dip varies from $\mathrm{N} 45^{\circ} \mathrm{E}$ to $\mathrm{N} 55^{\circ} \mathrm{E}$ and $25^{\circ}$ to $35^{\circ}$ southeast, respectively.

\subsection{Sample collection}

one soil and two rock samples were collected during drilling, placed in I-CHEM specialty cleaned glass containers, sealed and submitted to sample Receiving, Analytical Chemistry Division, Bldg. 4500S, ORNL. Chain of custody forms for these samples are included with this data package. Soil sample 988501 was collected in the split spoon interval from 0.3 feet to 0.5 feet on $9 / 28 / 87$, and rock sample $988 R 1$ was collected in the augered interval from 15.2 feet to 15.5 feet on $9 / 28 / 87$ and rock sample $988 R 2$ was collected in the drilled interval at 45.0 feet. 
Analytical results for the three samples described above can be obtained from the Remedial Action Program data base at ORNL.

\subsection{Instaliation and Development}

\subsubsection{Installation}

This was a "Type D" well. A 14-inch diameter boring was augered from ground surface to bedrock (20.0 feet). An 8-inch diameter string of decontaminated steel surface casing was installed and tremie grouted in place. The surface casing minimizes potential cross contamination between the regolith and bedrock water bearing zones. The air rotary method was then used to drill a 6-inch diameter boring to a total depth of 98.3 feet. The boring was grouted from 53.0 feet to 98.3 feet, bentonite pellets were poured in the boring up to $47.5^{\prime}$ and sand was poured in up to 46.0 feet. A 2-inch diameter stainless steel silt trap was installed from 45.8 to 46.0 feet. Above the silt trap, 2-inch diameter stainless steel screen was installed from 30.8 feet to 45.8 feet. A 2-inch diameter stainless steel casing was installed above the screen at 30.8 feet and extended 2.09 feet above ground surface. A sandpack was then poured into the annular space from 27.7 to 46.0 feet, with a 2.7 -foot bentonite seal poured into the annular space above the sandpack from 25.0 to 27.7 feet. The annular space from the top of the bentonite seal to the surface was tremie grouted with a cement/bentonite slurry. A detailed schematic of the well is included on the well installation/completion form. 
ERC / EDGE

Environmental

and Energy

Services Co.
MONITORING WELL PROGRAM WELL DATA NARRATVE

WELL NO. 988

\section{4 .2 Ne11 Development}

Well number 988 was developed to remove drill cuttings, silt, and other fines. The monitoring well was developed using a Geoguard pump with an air compressor. All pumps were cleaned prior to use according to specified cleaning procedures (see Paragraph 2.1). The well was developed until a measured total of 328 gallons of water had been evacuated and the clarity of the discharge water was approved by the company representative. The final turbidity value measured at completion was $3.0 \mathrm{NTU}$ 's. A development form showing the exact method of development and other pertinent data is appended.

2.4 .3

Installation of Dedicated Honitoring Well Pump

After the well was developed, a Geoguard Model No. 5614 dedicated monitoring well pump was installed on 5-17-90 at a depth of 42.5 feet below ground surface. These pumps are decontaminated at American sigma and are sent prepackaged. A copy of the pump certification is kept on file at ORNL.

\subsection{Hydraulic conductivity resting}

Well number 988 was tested for the determination of hydraulic conductivity of the aquifer in the vicinity of the well screen. This was accomplished by instantaneously adding a known quantity of water to the monitoring well and measuring the recovery of the water level over time. The changing water levels were 
measured using a Druck 15 psig pressure transducer and an Omnidata Datapod II data recorder. The hydraulic conductivity value of $4.95 \times 10^{-6} \mathrm{~cm} / \mathrm{second}$ (shown as permeability on the hydraulic conductivity calculations printout attached)was calculated using the Bouwer and Rice method. A computer printout of the hydraulic conductivity calculations is included in this data package. 
ERC / EDGE

Environmental

and Energy

WELL NO. 988

\section{PRE-DRILLING CHECKLIST FOR MONITORING WELLS}

PRE-DRILLING TASKS

1. EXCAVATION PERMIT OBTAINEO.

2. ALL EQUIPUENT HAS BEEN CLEANED BEFORE DRILUNG.

3a. SCREEN AND CASINGS HAVE BEEN WASHED, STEAMED, RINSED WIH DE-IONIZED OR DISTLLDD WATER, RINSED WTH ISOPROPY ALCOHOL WRAPPED WTH PROTECTVE COVERING AND STORED OFF THE GROUND.

36. PRE-PACKAGED SCREENS, CASINGS ANO CENTRALIZERS MERE USED.

4. MORK AREA FOR SAMPLE EXAMINATION COVERED WTH CLEAN POL YETHRENE.

5. CLEAN KNIES, GOVES, SAMPLE JARS AND LABELS ON-HANO.

6. POL YETHYENE COVER IN PLACE OVER HOLE.

AOOIMONAL NOTES/OBSERVA IONS:

\begin{tabular}{|c|c|}
\hline \multicolumn{2}{|c|}{ COMPLIANCE } \\
\hline$\frac{D A T E}{9-28-87}$ & $\frac{\mathbb{N} I \pi A L S}{B D H}$ \\
\hline $9-28-87$ & BOH \\
\hline$N / A$ & \\
\hline
\end{tabular}

$11-05-87 \quad B D H$

9-28-87 BDH

9-28-87 BDH

9-28-87 BDH

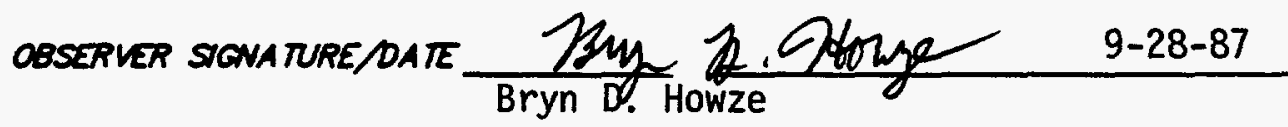


ERC / EDGE

Environmental

and Energy

WELL No._ $9 \underline{8} 8$

DECONTAMINATION CHECKLIST

DRILLING EQUIPMENT

\begin{tabular}{|c|c|c|c|c|c|}
\hline EQUIPMENT & SCRAPE & $\begin{array}{l}\text { STEAN } \\
\text { CLEAN }\end{array}$ & $\begin{array}{l}\text { STEAM } \\
\text { RINSE }\end{array}$ & $\begin{array}{c}\text { ISOPROPY } \\
\text { ALCOHOL } \\
\text { RINSE }\end{array}$ & $\begin{array}{c}\text { OEIONIZED } \\
\text { WATER } \\
\text { RINSE }\end{array}$ \\
\hline$R / G$ & $x$ & $x$ & $x$ & $N / A$ & $N / A$ \\
\hline AUGERS & $x$ & $x$ & $x$ & $x$ & $x$ \\
\hline BITS & $x$ & $x$ & $x$ & $x$ & $x$ \\
\hline ROOS & $x$ & $x$ & $x$ & $x$ & $x$ \\
\hline SAMPLERS & $x$ & $x$ & $x$ & $x$ & $x$ \\
\hline PIPES & $x$ & $x$ & $x$ & $x$ & $x$ \\
\hline WORK TOOLS & $X$ & $x$ & $x$ & $x$ & $x$ \\
\hline AUGER PINS & $x$ & $x$ & $X$ & $X$ & $x$ \\
\hline & & & & & \\
\hline & & & & & \\
\hline & & & & & \\
\hline & & & & & \\
\hline
\end{tabular}

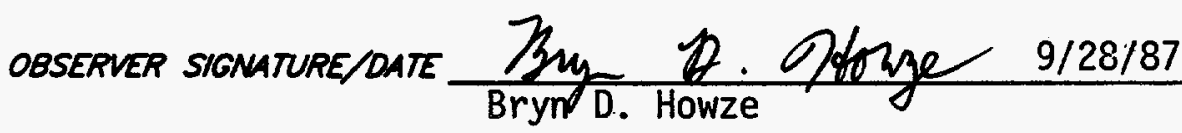

PAGE _ 2 OF 22. 


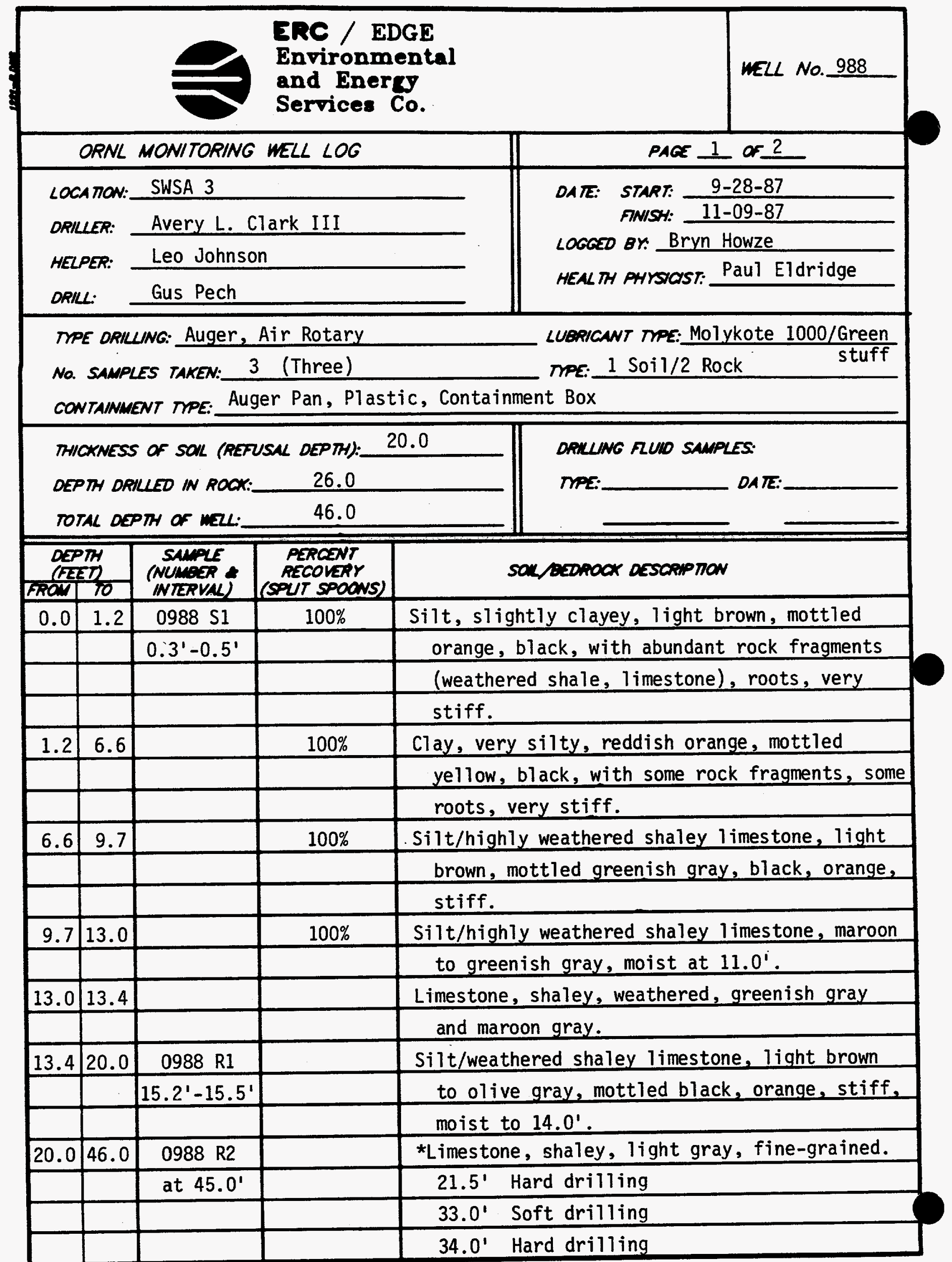




\begin{tabular}{|c|c|c|c|c|}
\hline \multicolumn{4}{|c|}{ ORNL MONITORING WELL LOG } & PAGE 2 of 2 \\
\hline \multicolumn{2}{|c|}{$\begin{array}{l}\text { DEPTH } \\
\text { (FEET) }\end{array}$} & $\begin{array}{l}\text { SAMPLE } \\
\text { (NUMBER } \\
\text { INIERVAL) }\end{array}$ & $\begin{array}{c}\text { PERCENT } \\
\text { RECOVERY } \\
\text { (SPUT SPOONS) }\end{array}$ & SOL/BEDROCK DESCRIPTION \\
\hline \multirow[t]{8}{*}{20.0} & 46.0 & & & (continued from page 1 ) \\
\hline & & & & $35.0^{\prime}$ Soft drilling \\
\hline & & & & 38.5' Hard drilling \\
\hline & 46.0 & & & Total Depth \\
\hline & & & & \\
\hline & & & & * A detailed lithologic log could not be pro- \\
\hline & & & & vided from $20.0^{\prime}$ to $46.0^{\prime}$ due to the use of \\
\hline & & & & a containment box. \\
\hline & & & & \\
\hline & & & & \\
\hline & & & & \\
\hline & & & & \\
\hline & & & & \\
\hline & & & & \\
\hline & & & & . \\
\hline & & & & \\
\hline & & & & \\
\hline & & & & \\
\hline & & & & \\
\hline & & & & \\
\hline & & & & \\
\hline & & & & \\
\hline & & & & \\
\hline & & & & \\
\hline & & & & \\
\hline & & & & \\
\hline & & & & \\
\hline & & & & \\
\hline & & & & \\
\hline & & & & \\
\hline & & & & \\
\hline & & & & \\
\hline & & & & \\
\hline
\end{tabular}




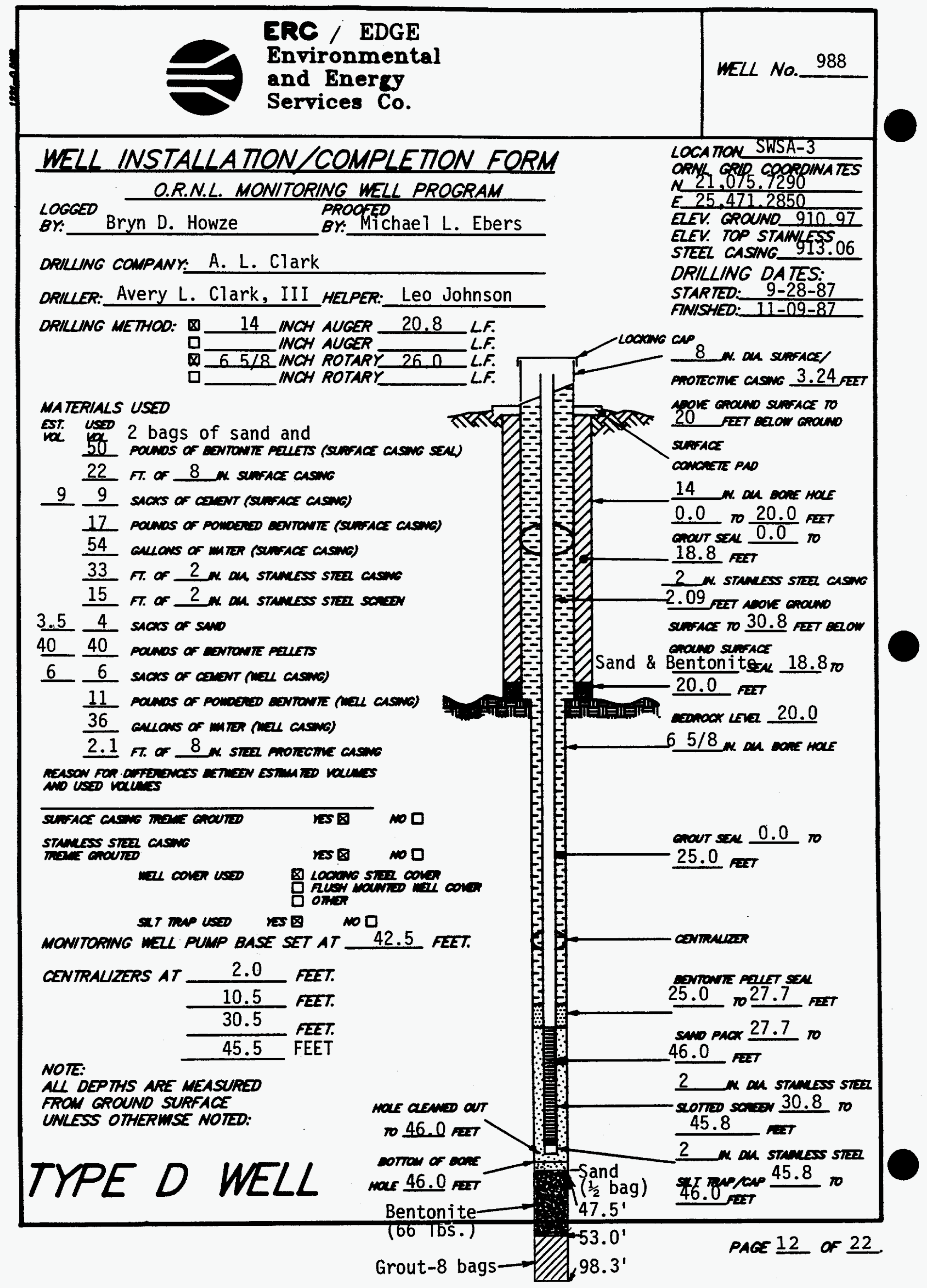




\section{MONITORING WELL MATERIALS CERTFICATION}

\begin{tabular}{|c|c|c|}
\hline ITEM $/ M A T E R I A L$ & DAIE USED & BATCH NUWBER \\
\hline \multirow{2}{*}{ SANO } & $10-08-87$ & 2 \\
\hline & $\begin{array}{l}11-02 / 11-05 \\
10-06-87\end{array}$ & 2 \\
\hline \multirow{2}{*}{ BENTONITE } & $11-08-87$ & 2 \\
\hline & $\begin{array}{l}10-30-87 \\
11-06-87\end{array}$ & 2 \\
\hline (PREPACKACED $\mathrm{a}$ NOS & $11-05-87$ & 5 \\
\hline (PREPACKAGED a NO & $11-05-87$ & 5 \\
\hline $\begin{array}{l}\text { STAINLESS STEEL CENTRALIZERS (PREPACKAGED } \\
\text { a nO }\end{array}$ & $11-05-87$ & 5 \\
\hline (PREPACKAGED $\left.8 \begin{array}{c}\text { KES } \\
\text { NO }\end{array}\right)$ & $11-05-87$ & 5 \\
\hline MONITORING MELL PUMP (PREPACKAGED 1 YES & $5-17-90$ & 5 \\
\hline \multirow{2}{*}{ GROUT } & $10-08-87$ & 11 \\
\hline & $\begin{array}{l}10-29-87 \\
11-09-87\end{array}$ & 11 \\
\hline \multicolumn{3}{|l|}{ WELL COVERS } \\
\hline SURFACE CASING & $10-08-87$ & 2 \\
\hline
\end{tabular}

COMMENTS:

OBSERVER SIONATURE/OATE $\frac{\text { Byy }}{\text { Bryt D. Howze }}$ 


\section{POST-MELL COMPLETION \\ CHECKLIST}

\section{ROST-MELL COMRLETION TASKS}

\section{COMPLIANCE \\ DA.TE INITALS}

1. WU SCRAPED FRON AUGERS SAMPLERS AND ALL OTHER EQUIPMENT.

$\begin{array}{ll}11-09-87 & B D H \\ & B D H \\ \end{array}$

2. ALL WUD FROW RIG ANO EQUPIEENT SCRAPINGS AND CUTINOS DISPOSED OF NN ACCORDANCE MTH THE SPECATCA IION" PROWOED.

3. WEL DEVEZOPED IN ACCOROANCE WTH THE SPECTICATION" PROVOED AND DETAKS OF THE DEVELOPWENT ACTVTY RECOROED.

4. ORKLWG STE PROPERLY CLEANED UP AFTER COMPLETION OF WZL INSTALAMON.

5-17-90 DCL

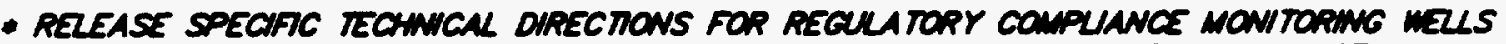
PHASE l, OAK RIDGE NATIONAL LABORATORY, OAK RDOE MO K-4147, NPRK 1987.

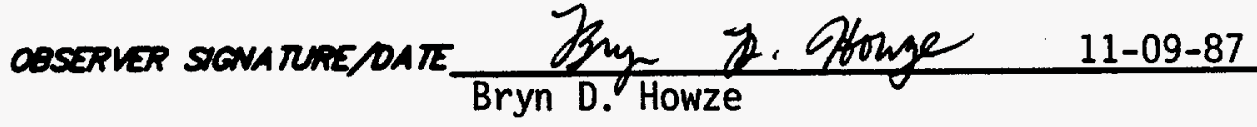

D.Chales Sute $5-17-90$

D. Charles Lytle 


\section{MONITORING WELL DEVELOPMENT FORM}

\section{DEVELOPMENT DETAILS}

METHOD OF

QEVELOPMENT: Surging and Pumping

DEVELOPMENT

BEGAN DATE: $\quad 5-11-90$ TME:

DEVELOPMENT

ENDING DATE: $\quad 5-17-90$

DEVELOPMENT

OBSERVED BY:

D. Charles Lytle

ONE WELL VOLUME: 10.7 GALLONS

TOTAL GALLONS PUMPED: 328 TOTAL WELL VOLUMES PUMPED: 30.6

INITAL PH: 7.8 FNAL PH: 7.8

INITAL CONDUCTUTY ( $\mathrm{HS} / \mathrm{cm}): 671$ FNAL CONDUCTUTY $(\mu \mathrm{s} / \mathrm{cm}): 683$

DESCRIPTION OF INITAL TURBIDITY: ClOUdY

DESCRIPTION OF FINAL TURBIDITY: Clear

FNAL MEASURED RURBIDITY: 3.0 NTU'S

WELL APPROVED BY: R. C. Willi IamS MMES

ODOR

OF WATER:

WA TER

DISCHARGED

TO:

Q GROUND SURFACE
STORM SEMERS
DRUMS

口 TANK TRUCK

口 STORAGE TANKS

口 OTHER

INITAL PRE-DEVELOPMENT WATER DEPTH:

23.6 feet from ground surface.

DEVELOPMENT OBSERVATIONS

OBSERVER SIGNATURE DATE D. Chales Sytele

$5 / 17 / 90$

D. Charles Lytle

PAGE $\underline{15}$ of 22. 


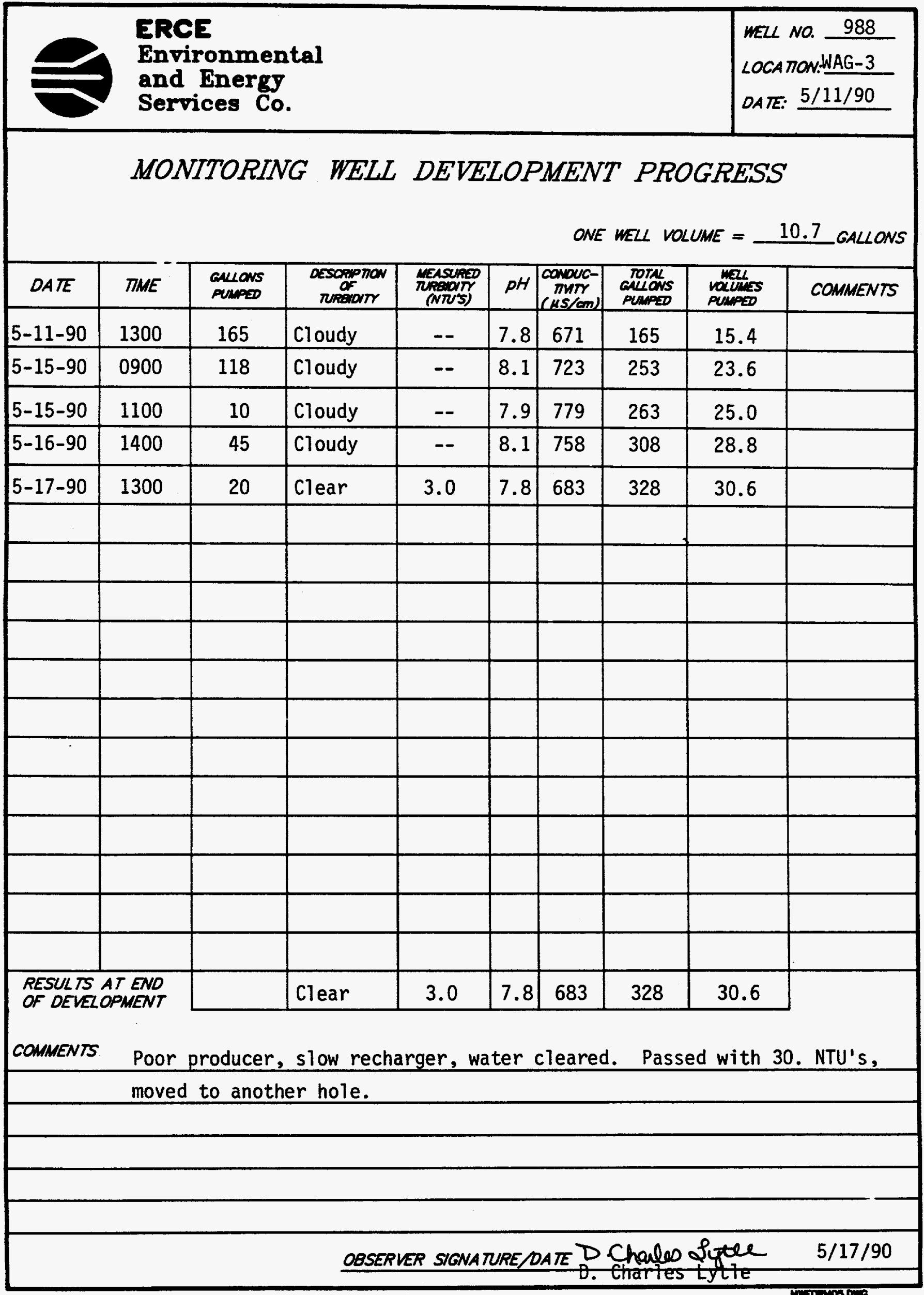




\section{HYDRAULIC CONDUCTIVTY CALCULATIONS}

\begin{tabular}{|c|c|c|}
\hline ISEE & $\begin{array}{l}\text { DEFTH TO WATEE } \\
\text { (FEET) }\end{array}$ & $\begin{array}{l}\text { HEAD } \\
\text { (FEET) }\end{array}$ \\
\hline $10 . \mathrm{DO}$ & 3.390 & 3.500 \\
\hline 20.90 & 3.260 & $\because 260$ \\
\hline 30.09 & $3 \times 190$ & $\because=19 m$ \\
\hline 40.60 & $3=210$ & $\because=210$ \\
\hline 50.00 & 3.20 & $\exists .220$ \\
\hline $6 D .90$ & $3: 160$ & 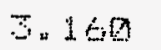 \\
\hline 75.98 & 3.190 & 7.190 \\
\hline 90.00 & $\forall=130$ & $\because: 1.50$ \\
\hline 195,00 & 3.100 & 3.100 \\
\hline 120.00 & 3.090 & $\because .990$ \\
\hline 150.00 & 5.046 & $\because, 048$ \\
\hline 180.00 & 3.000 & $\because .090$ \\
\hline 240.00 & 2.970 & $\therefore .970$ \\
\hline 370.00 & 2.860 & $2.54 \mathrm{D}$ \\
\hline 560,00 & 2.810 & 2.810 \\
\hline 420.80 & $2 n 740$ & $2: 740$ \\
\hline $480 \cdot 90$ & 2.700 & $2.70 Q$ \\
\hline 540.00 & $2 \div 750$ & 2.750 \\
\hline$\triangle 80 ., 00$ & 2.710 & 2.710 \\
\hline 720.00 & 2.670 & 2.670 \\
\hline 840.00 & 2.550 & 2.550 \\
\hline $9 B Q .0 Q$ & 2.440 & 2.440 \\
\hline 1080.00 & 2.380 & 2.300 \\
\hline 1200,00 & 2.380 & 2.580 \\
\hline 1520,90 & 2.320 & 2.320 \\
\hline 1440,00 & 2.320 & 2.320 \\
\hline 1560.00 & 2.280 & 2.280 \\
\hline 1680.00 & 2.190 & 2.190 \\
\hline 1900.00 & 2.190 & 2.190 \\
\hline 1920.00 & $2: 1.20$ & 2.120 \\
\hline 2040.00 & 2.020 & 2.020 \\
\hline 2160.00 & 2.030 & 2.0 .0 \\
\hline
\end{tabular}

METHDD OF EOUWEF: AND FICE

COMPLTED RESULTS USING DIAMETEF OF DFILLED HOLE:

FEFIMEAEILITY $=1.62 E-07 \mathrm{FT} / \mathrm{sec} \quad=4.95 \mathrm{E}-06 \mathrm{CM} / \mathrm{sec}$

TFANSMISSIUITY $=2,44 E-06$ FT*2/SEC 


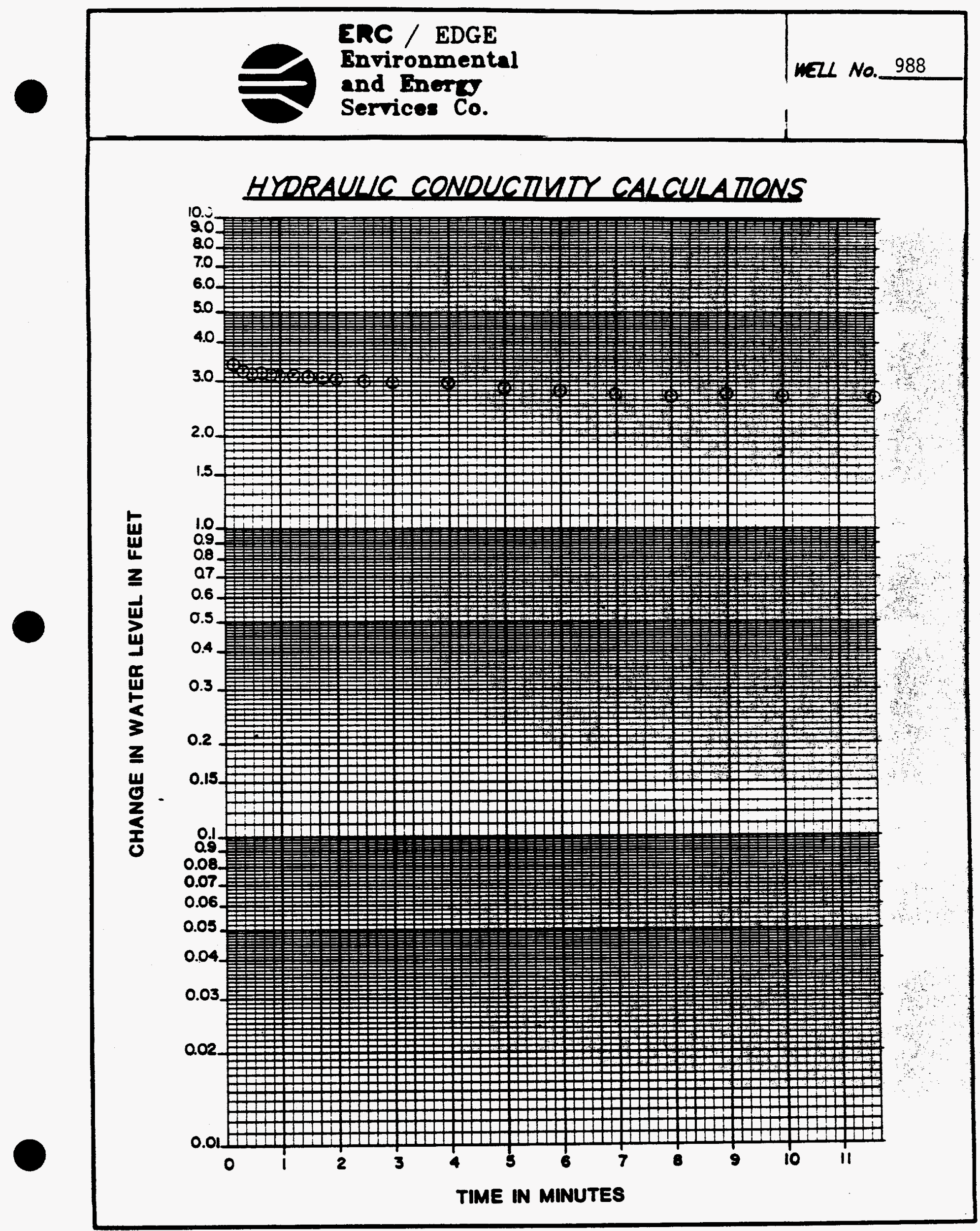




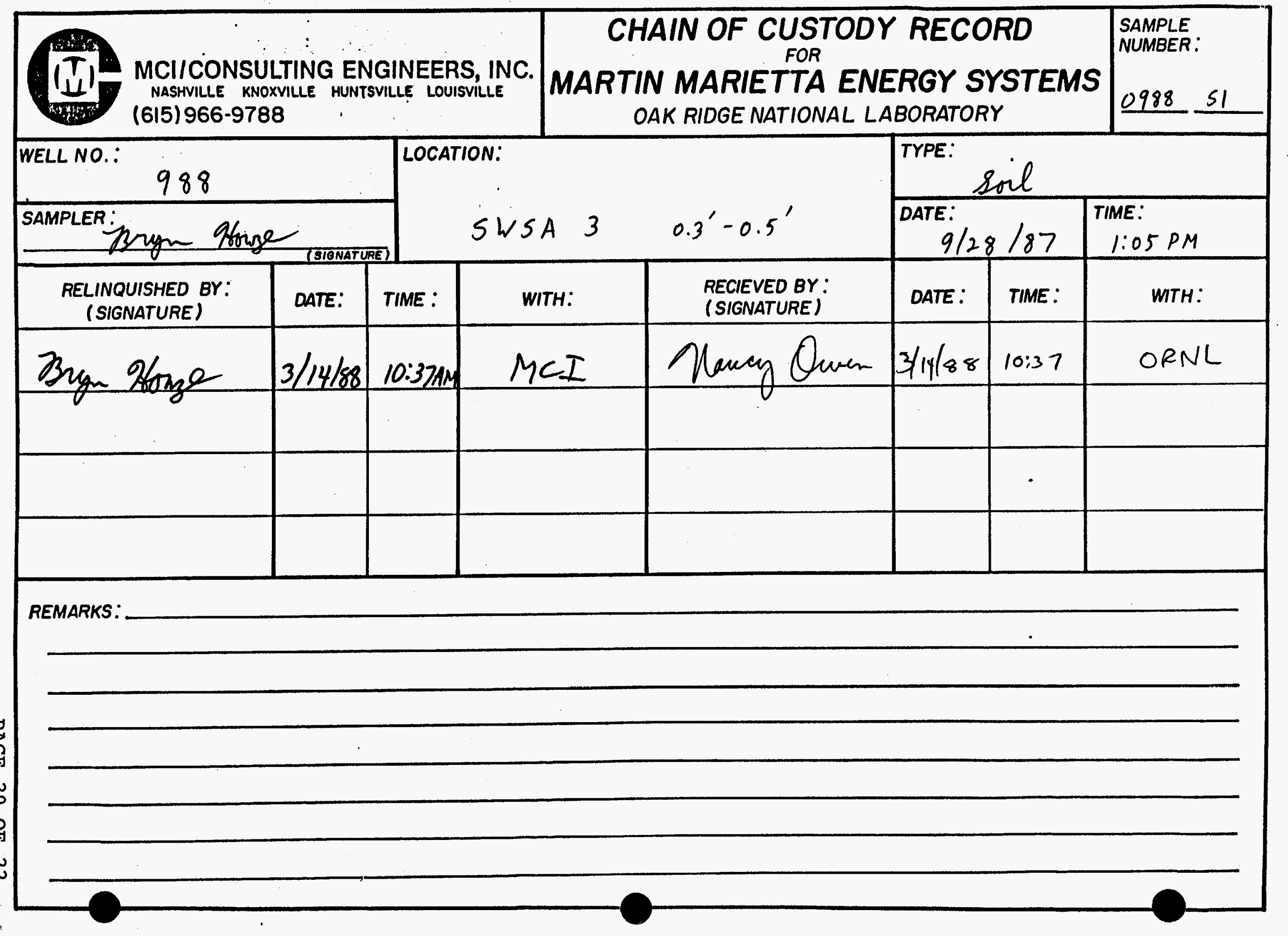




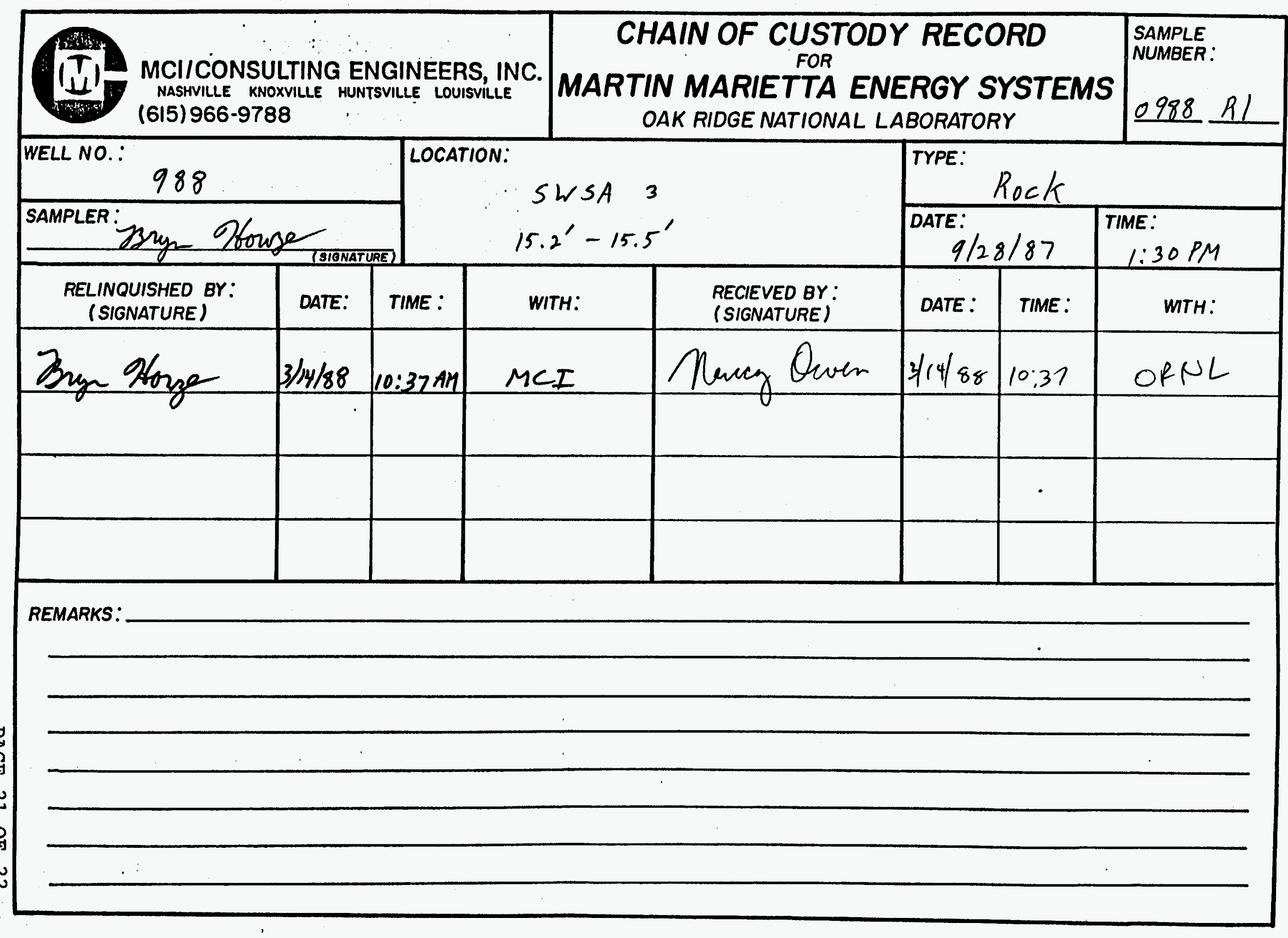




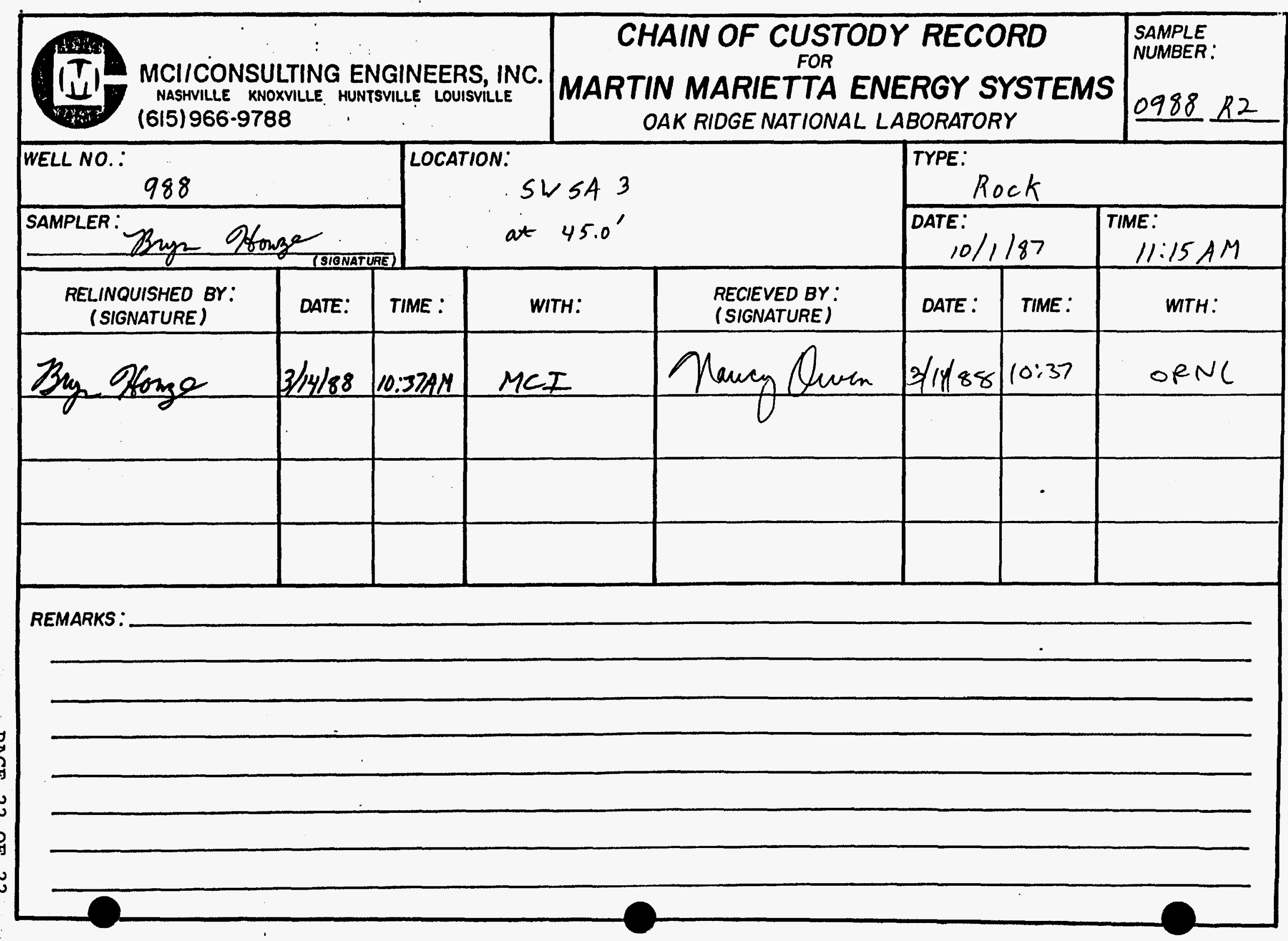


ERC / EDGE

Environmental

and Energy

Services Co.

General Information

\subsection{Well Location}

Monitoring well number 990 is located in WAG 3. It is located in the northwest corner of the contractors landfill. The location is shown on ORNL drawing number C3E20004 A075. Survey coordinates for this well are $N 21,657.3446, E 24,723.6199$ (X-10 grid) or latitude $35^{\circ}-54^{\prime}-58.03^{\prime \prime}$ and longitude $84^{\circ}-20^{\prime}-02.17^{\prime \prime}$. Coordinate data were provided by Martin Marietta Energy systems. The method used for conversion from $\mathrm{X}-10$ grid to Tennessee-Lambert State Plane Coordinates came from the publication "Tennessee Valley Authority Data Services Branch and Mapping Services Branch, Oak Ridge, Tennessee, DOE Plant Control, November 6, 1985, Field Book: ESS-3115, pp. 1-20." The latitude and longitude were calculated by Adams Craft Herz Walker Engineering, Inc., using methods from the U.S. Coast and Geodetic Survey Publication 62-4, "State Plane Coordinates by Automatic Data Processing."

\subsection{Drilling Information}

Well number 990 was drilled by A. L. Clark Drilling Services, Inc. A Schramm Rotadrill rig was used to drill this boring for monitor well installation under operation of Rick Pickel with the assistance of Danny Julian. Drilling commenced on 12-10-87 and was finished on 12-31-87. Paragraph 2.4.1 includes a detailed discussion of the well installation and a well schematic is included on the well installation/ completion form. A synopsis of the drilling activity 
follows. This information was typed directly from field notes and was edited only when necessary for clarification.

12-10-87 The rig was mobilized to the staked location and set up. The boring was split spooned from $0^{\prime}$ to 20.81 .

12-11-87 Augered from $O^{\prime}$ to 8.0 feet with 14-inch augers.

12-16-87 Augered from 8 feet to 24.2 feet.

12-18-87 Cut and steam cleaned 26.0 feet of surface casing.

12-21-87 Ran in surface casing, had 2.2 feet of stickup. Grouted surface casing with 20 feet of 1-inch tremie pipe.

12-29-87 Drilled with 8 5/8" air rotary tricone and containment from 23.8 feet to 41.0 feet.

12-30-87 Ran in 15 feet of 4-inch stainless steel screen, 27 feet of stainless steel casing, sand pack and pellet bentonite seal.

12-31-87 Grouted annulus from the surface to 22 feet through 20 feet of 1-inch PVC tremie pipe.

This well was logged by ERC Environmental and Energy Services Co., Inc., hydrogeologist Bryn D. Howze and Michael L. Ebers. All well construction materials and supplies were from Martin Marietta Energy systems approved batches. The batch origin of individual items is shown on the included Monitoring Well Materials Certification form. 
2.0 Technical Information

\subsection{Decontamination Procedures}

The drilling rig, down hole tools, surface casing, stainless steel screen, stainless steel casing, centralizers, and stainless steel silt trap underwent the cleaning decontamination procedures outlined in the drilling specifications (Release specific Technical Directions for Regulatory Compliance Monitoring Wells Phase 1 , Oak Ridge National Laboratory, Oak Ridge, w.0. K-4147, April 1987, pgs. 2-4). A checklist of the cleaned materials is included with this data package.

\subsection{9}

WAG 3 is located in Melton valley which is in the valley and Ridge Physiographic Province of East Tennessee. WAG 3 is underlain by limestone, siltstone and shale of the Middle Ordovician Chickamauga Group. The Chickamauga Group consists of eight units, designated by letters "A" to "H" (Stockdale, 1951). WAG 3 is underlain by units E, F, G and H. These units consist of thin bedded nodular limestone with clay and shale partings. A portion of unit $H$ and unit F consists of calcareous siltstone alternating with beds of olive gray to maroon shale. Strike and dip varies from $\mathrm{N} 45^{\circ} \mathrm{E}$ to $\mathrm{N} 55^{\circ} \mathrm{E}$ and $25^{\circ}$ to $35^{\circ}$ southeast, respectively. 


\subsection{Bample collection}

Two soil samples were collected during drilling, placed in I-CHEM specialty cleaned glass containers, sealed and submitted to Sample Receiving, Analytical Chemistry Division, Bldg. 4500S, ORNL. Chain of custody forms for these samples are included with this data package. Soil sample 990501 was collected in the split spoon interval from 0.6 feet to 0.8 feet on 12-10-87 and soil sample 990S02 was collected in the split spoon interval from 15.8 feet to 16.0 feet on 12-10-87.

A drill water sample was collected from the water pump on the drill rig on 12-29-87. Analytical results for the three samples described above can be obtained from the Remedial Action Program data base at ORNL.

\subsection{Installation and Development}

\subsubsection{Installation}

This was a "Type B" well. A 14-inch diameter boring was augered from ground surface to bedrock (24.0 feet). A 10-inch diameter string of decontaminated steel surface casing was installed and tremie grouted in place. The surface casing minimizes potential cross contamination between the regolith and bedrock water bearing zones. The air rotary method was then used to drill an 8-inch diameter boring to a total depth of 40.8 feet. A 4-inch diameter stainless steel silt trap was installed from 40.5 to 40.8 feet. Above the silt trap, a 4-inch diameter stainless steel 
screen was installed from 25.5 feet to 40.5 feet. A 4-inch diameter stainless steel casing was installed from the top of the screen at 25.5 feet and extending 1.12 feet above ground surface. A sandpack was then poured into the annular space from 24.0 to 40.8 feet, with a 2.0-foot bentonite seal poured into the annular space above the sandpack from 22.0 to 24.0 feet. The annular space from the top of the bentonite seal to the surface was tremie grouted with a cement/bentonite slurry. A detailed schematic of the well is included on the well installation/completion form.

\subsubsection{Wel1 Development}

Well number 990 was developed to remove drill cuttings, silt, and other fines. The monitoring well was developed using a Geoguard pump with an air compressor. All pumps were cleaned prior to use according to specified cleaning procedures (see Paragraph 2.1). The well was developed until a measured total of 440 gallons of water had been evacuated and the clarity of the discharge water was approved by the company representative. The final turbidity value measured at completion was $3.0 \mathrm{NTU}$ 's. A development form showing the exact method of development and other pertinent data is appended.

\subsubsection{Installation of Dedicated Monitoring Well Pump}

After the well was developed, a Geoguard Model No. 5614 dedicated monitoring well pump was installed on 5-7-90 at a depth of 39.1 feet below ground 
surface. These pumps are decontaminated at American Sigma and are sent prepackaged. A copy of the pump certification is kept on file at ORNL.

\subsection{Hydraulic conductivity Testing}

Well number 990 was tested for the determination of hydraulic conductivity of the aquifer in the vicinity of the well screen. This was accomplished by instantaneously removing a known quantity of water from the monitoring well and measuring the recovery of the water level over time. The changing water levels were measured using a Druck 15 psig pressure transducer and an Omnidata Datapod II data recorder. The hydraulic conductivity value of $3.57 \times 10^{-5}$ $\mathrm{cm} / \mathrm{second}$ (shown as permeability on the hydraulic conductivity calculations printout attached) was calculated using the Bouwer and Rice method. A computer printout of the hydraulic conductivity calculations is included in this data package. 
ERC / EDGE

Environmental

and Energy

WELL NO. 990

Services Co.

\section{PRE-DRILLING CHECKLIST FOR MONITORING WELLS}

\section{PRE-ORILLING TASKS}

1. EXCAVATION PERMIT OBTAINED.

2. ALL EQUIPMENT HAS BEEN CLEANED BEFORE DRILLNG.

3o. SCREEN AND CASINGS HAVE BEEN WASHED, STEAMED, WTH ISOPROPY ALCOHOL WRAPPED WTH PROTECTIE COVERING AND STORED OFF THE GROUND.

36. PRE-PACKAGED SCREENS, CASINGS AND CENTRALIZERS MERE USED.

4. WORK AREA FOR SAMPLE EXAMINATION COVERED WTH CLEAN POL YETHRENE.

5. CLEAN KNIVES, QLOVES, SAMPLE JARS AND LABEZS ON-HAND.

6. POL YETHYENE COVER IN PLACE OVER HOLE.

$\begin{array}{ll}12-30-87 & M E \\ 12-10-87 & M E \\ 12-10-87 & M E\end{array}$

$12-10-87$

DATE INITALS

12-10-87 MLE

$12-10-87$

NHe

$\mathrm{N} / \mathrm{A}$

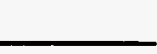

بln RINSED WIT DE-IONIZED OR DISTLLED WATER, RINSED

COMPLIANCE

ADOITONAL NOTES/OBSERVATIONS

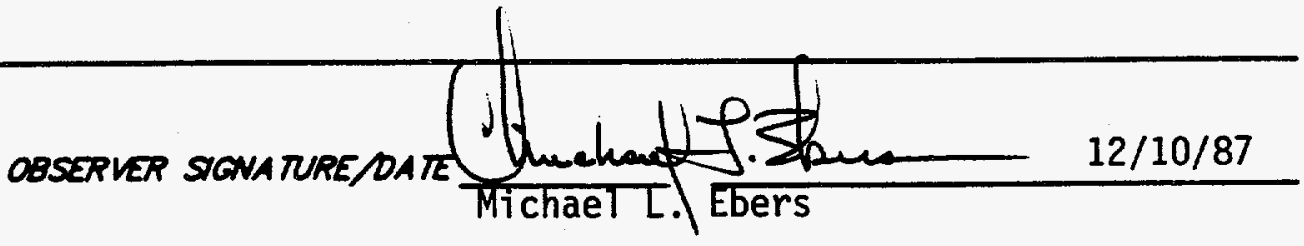

PAGE 7 of 22 


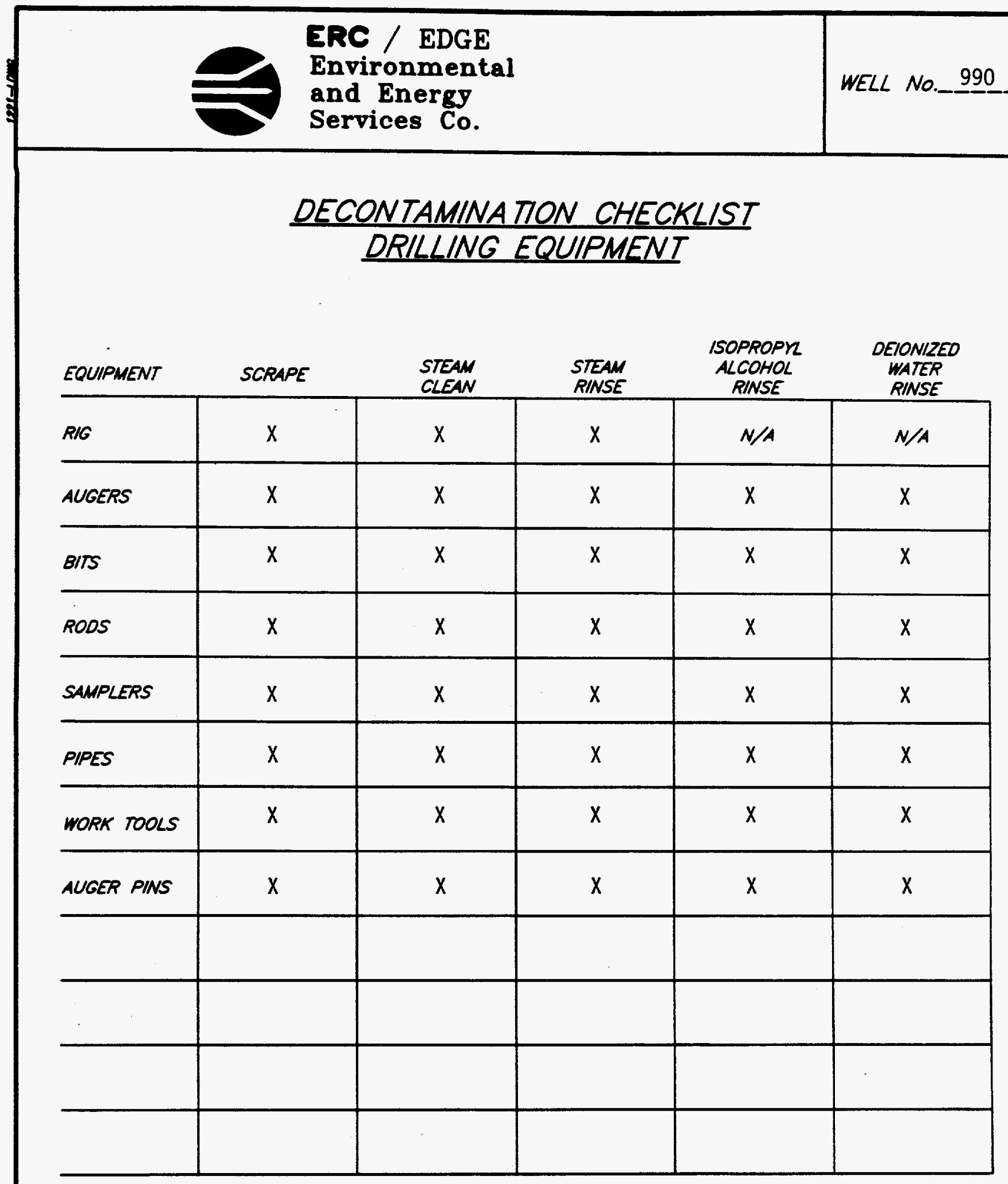

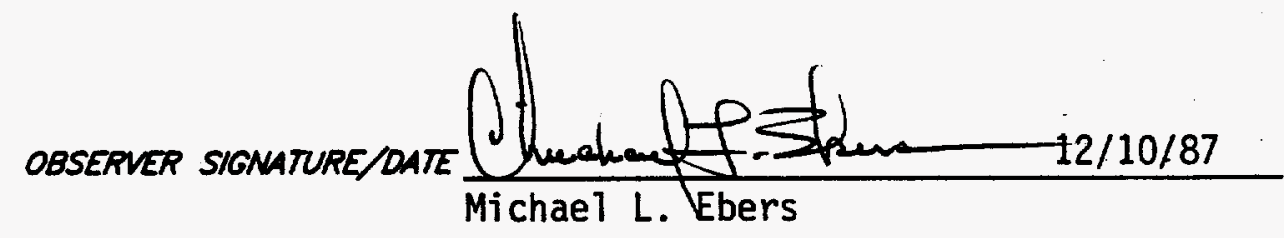




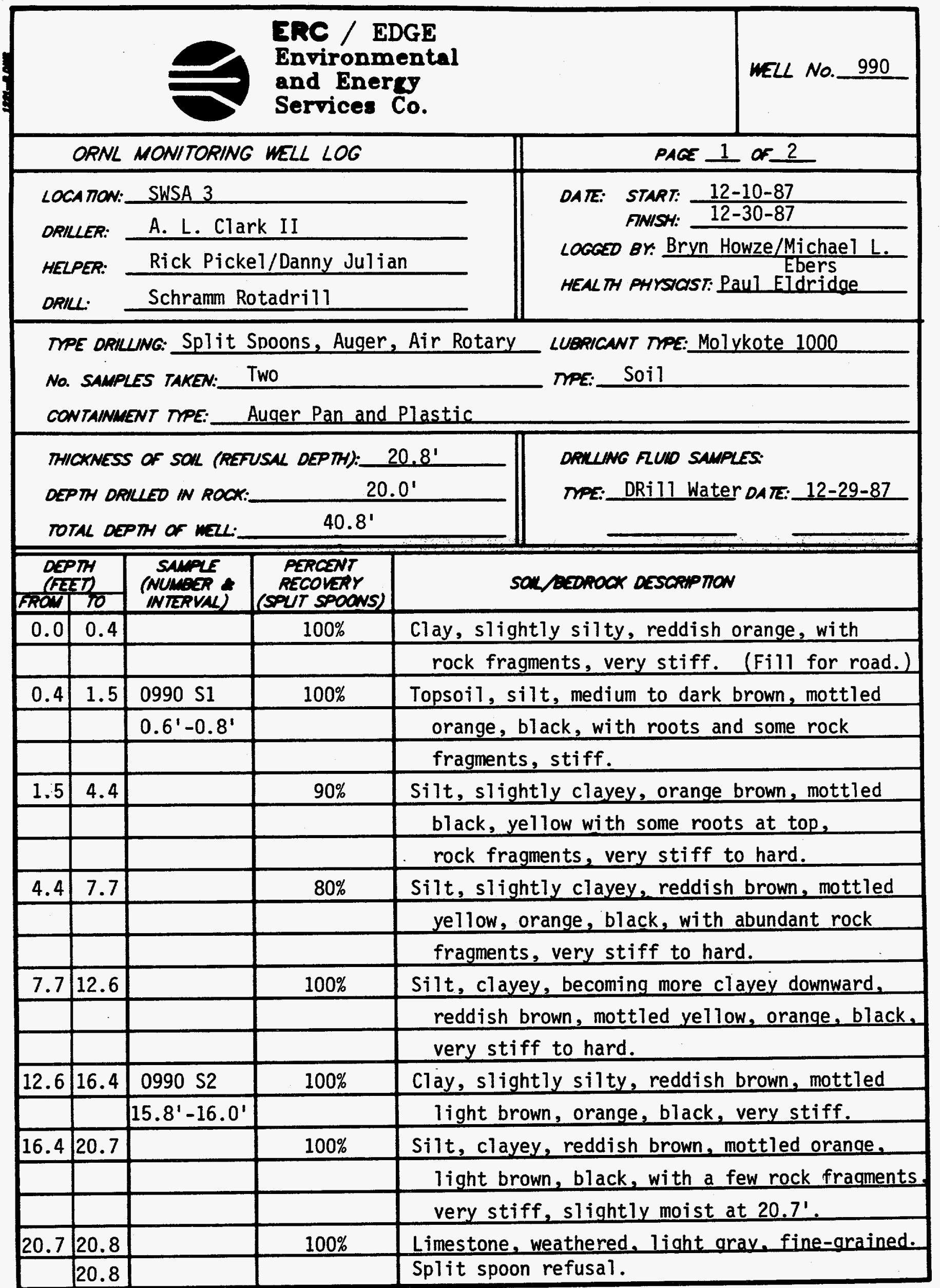




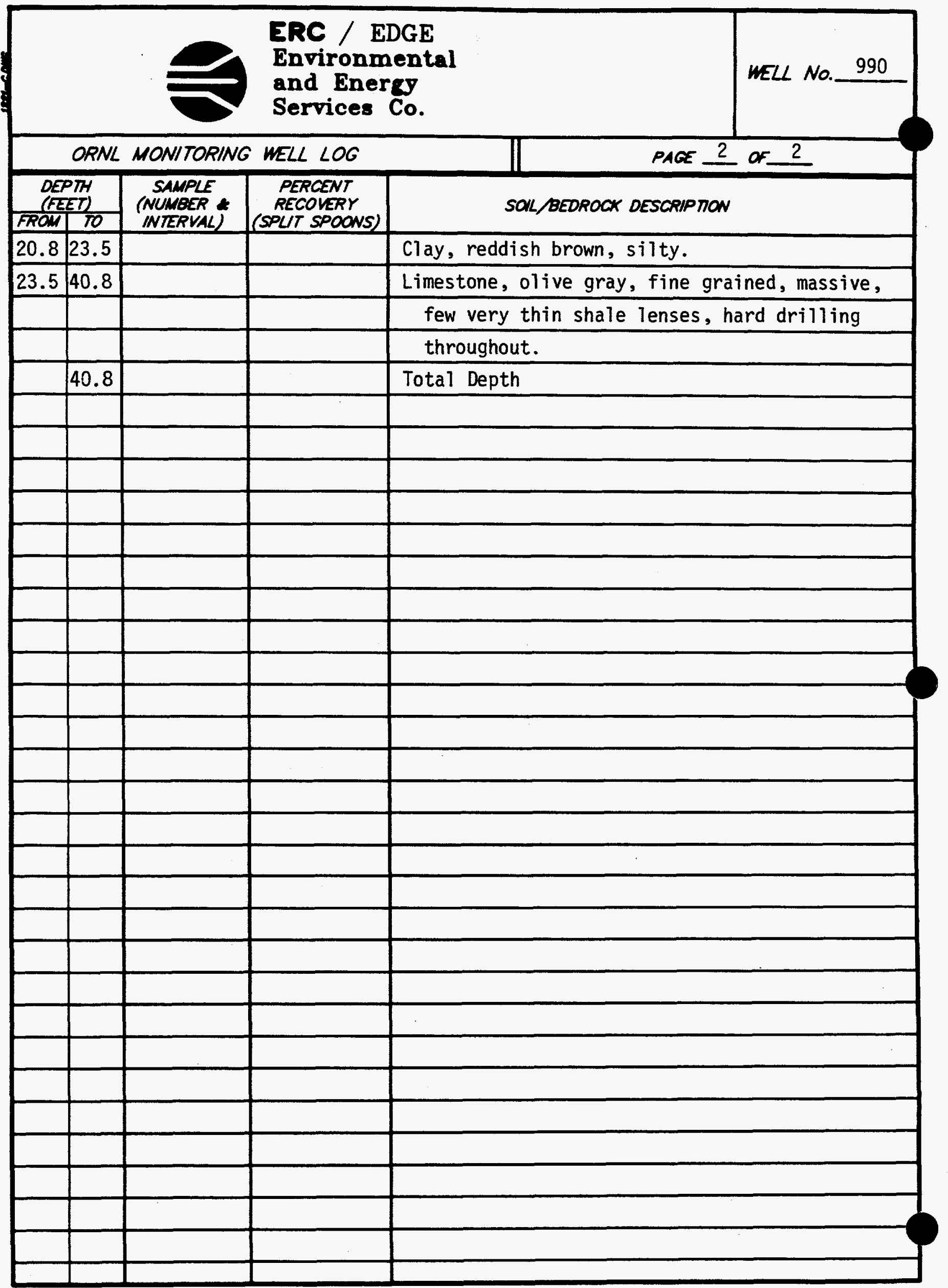

PACE 10 of 22. 


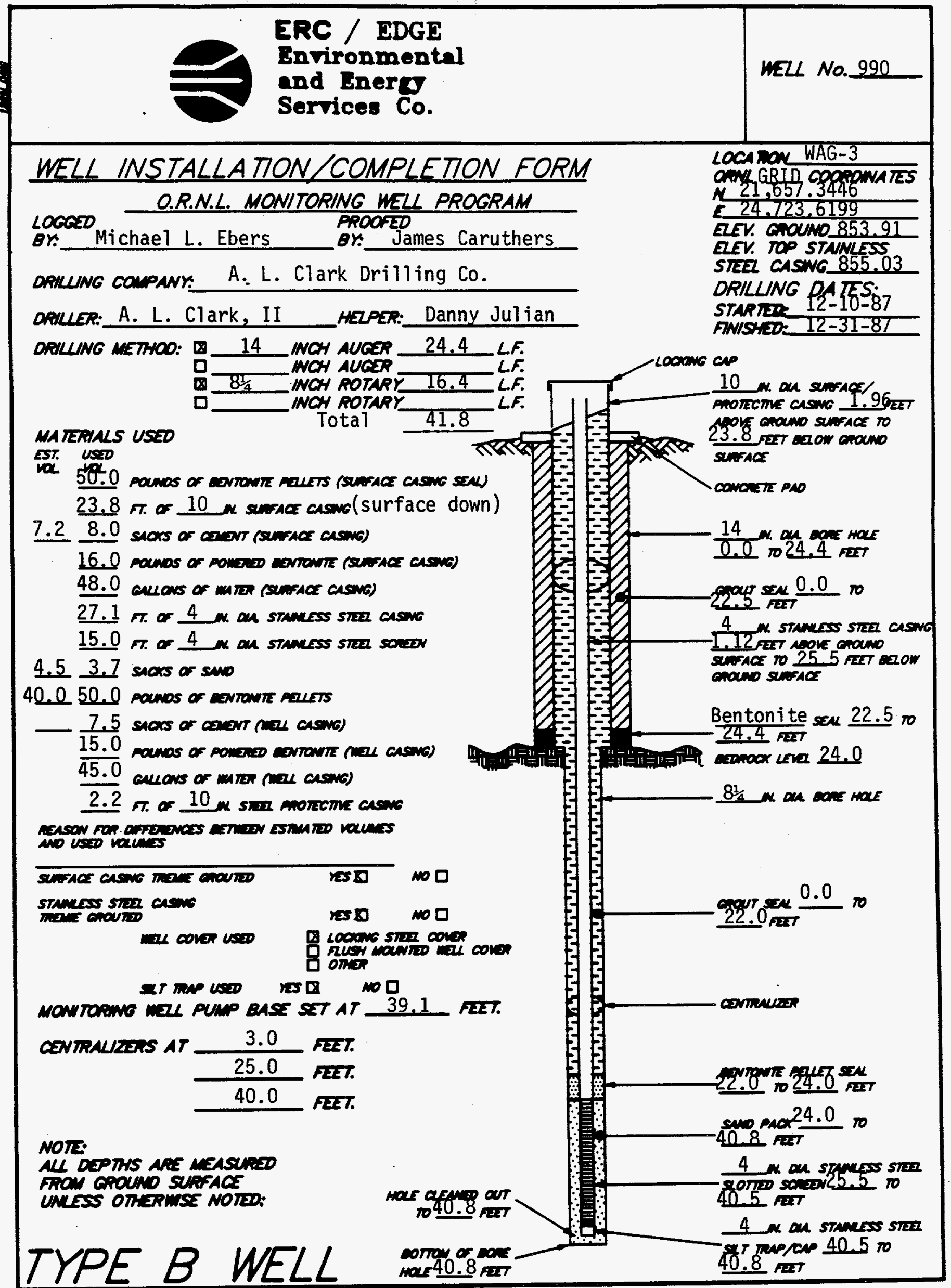


ERe / EDGE

Environmental

WELL No. 990

and Energy

Services Co.

DATE: $12 / 21 / 87$

\section{MONITORING WELL MATERIALS CERTIFICATION}

ITEM MA TERIAL

\begin{tabular}{|c|c|c|}
\hline & DAIE USED & BATCH NUMBER \\
\hline & $12-30-87$ & 3 \\
\hline & 121007 & \\
\hline & $12-30-87$ & 3 \\
\hline (YES) & $12-30-87$ & 5 \\
\hline 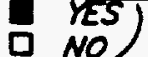 & $12-30-87$ & 5 \\
\hline $\begin{array}{l}\text { Yes) } \\
\text { NO }\end{array}$ & $12-30-87$ & 5 \\
\hline$\left(\begin{array}{c}\text { YES } \\
\text { NO }\end{array}\right.$ & $12-30-87$ & 5 \\
\hline$\left(\begin{array}{l}1 \\
\text { NOS }\end{array}\right)$ & $5-07-90$ & 5 \\
\hline & $12-21-87$ & 15 \\
\hline & $12-31-87$ & 15 \\
\hline & $12-30-87$ & 1 \\
\hline & $12-21-87$ & 2 \\
\hline
\end{tabular}

\section{COMMENTS:}

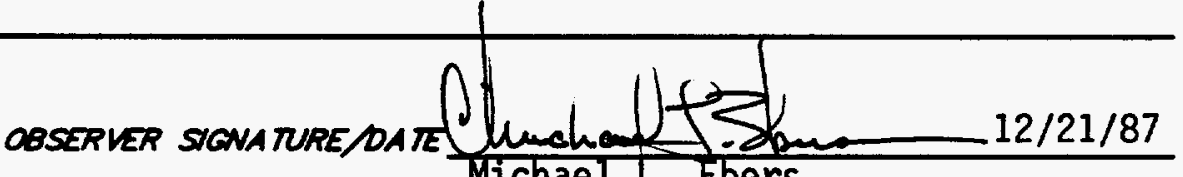

Michael L. Ebers

PAGE 12 of 22 


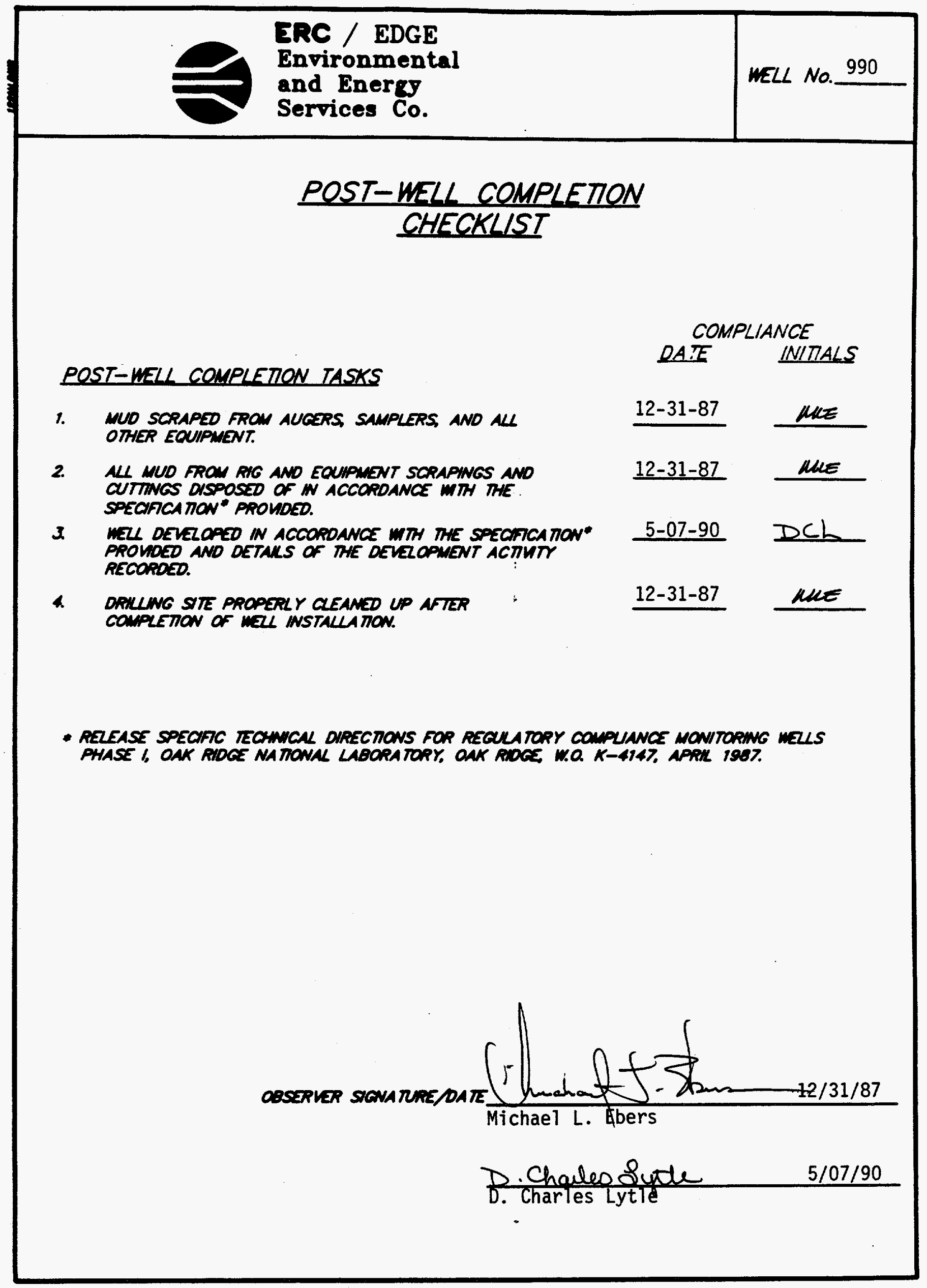

PACE 13 of 22. 
DEVELOPMENT DETAILS

METHOD OF

DEVELOPMENT: Surging and Pumping

DEVELOPMENT $\quad 4-18-90$

BEGAN DATE:

MME:

DEVELOPMENT: $\quad 5-07-90$
ENDING DATE:

DEVELOPMENT

OBSERVED BY: D. Charles Lytle

ONE WELL VOLUME: 15.8

GALLONS

TOTAL GALLONS PUMPED: 444 TOTAL WELL VOLUMES PUMPED: 28.1

INITAL PH: 7.5 FNAL PH: 7.9

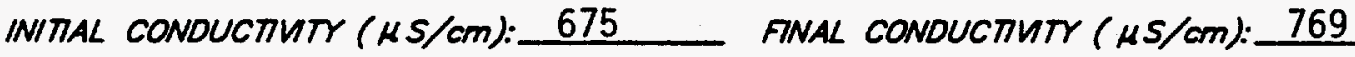

OESCRIPTION OF INITAL TURBIDITY: Slightly Cloudy

DESCRIPTION OF FINAL TURBIDITY: Clear

FNAL MEASURED TURBIDITY: 3.0 NTU'S

WELL APPROVED $B Y$ R. C. Williams MMES

\begin{tabular}{lll} 
ODOR & & \\
OF WATER: & None & \\
\hline WA TER & Q GROUND SURFACE & 口 TANK IRUCK \\
DISCHARGED & STORM SEWERS & STORAGE TANKS \\
TO: & D DRUMS & D OTHER \\
\hline
\end{tabular}

INITAL PRE-DEVELOPMENT

WATER DEPTH:

29.0 feet from ground surface.

DEVELOPMENT OBSERVATIONS

OBSERVER SIGNATURE DATE

D. Chanleosyete $5 / 07 / 90$
D. Charles Lytle




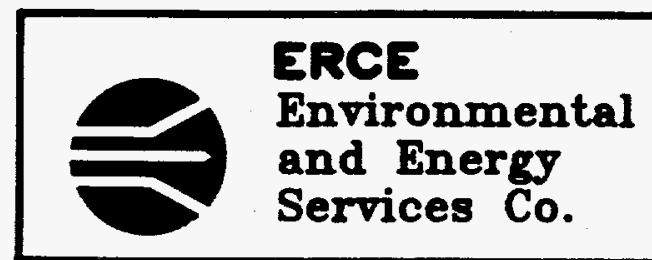

WELL NO. 990

LOCA TON: WAG-3

OATE: $4 / 18 / 90$

\section{MONITORING WELL DEVELOPMENT PROGRESS}

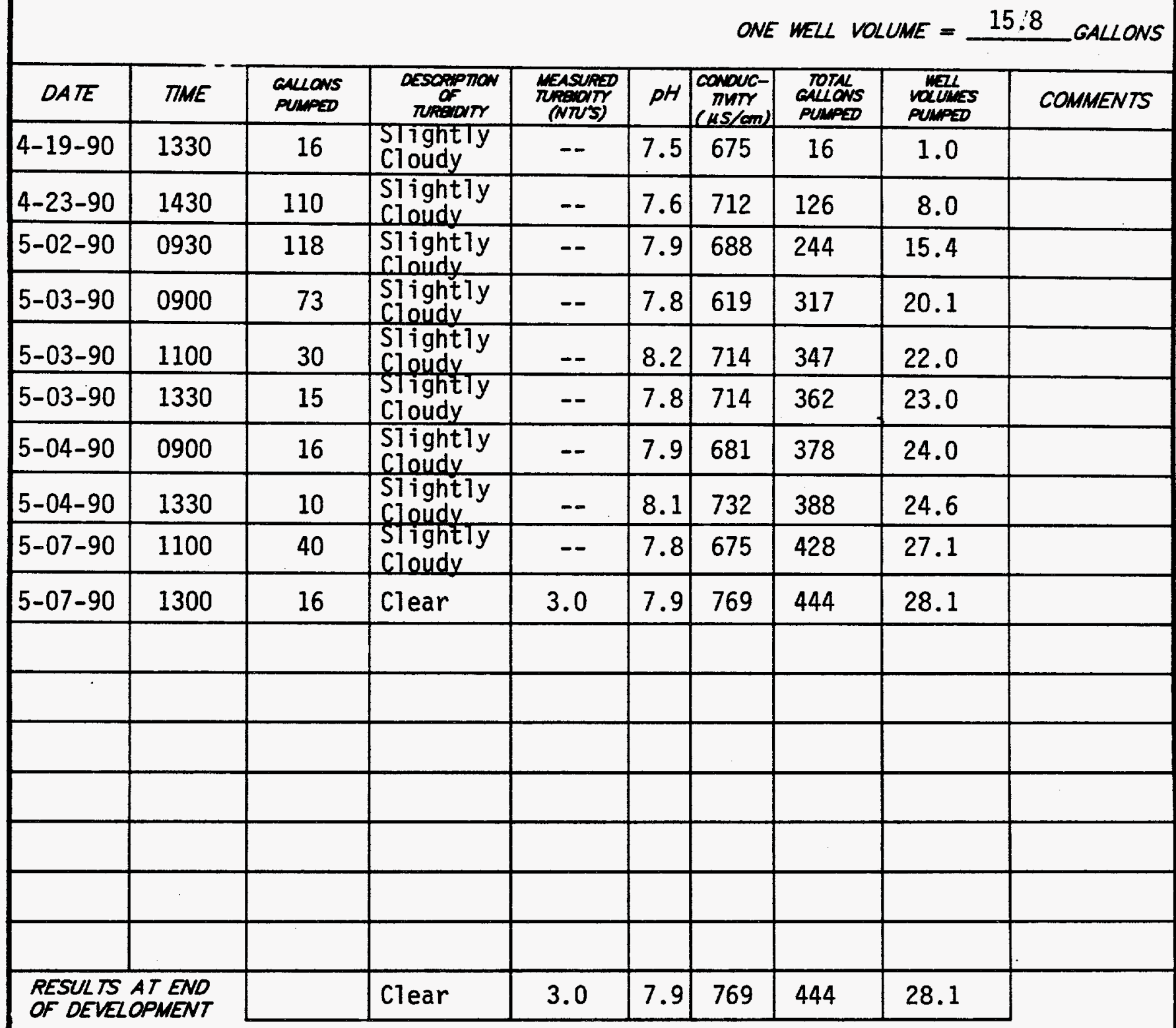

COMMENTS

Fair producer. Water cleared, stayed clear even after surging.

Passed and moved to another hole.

OBSERVER SIGNATURE/DATE D. Challes Syde 5/07/90
D. Chartes Lythe

PAGE 15 of 22 . 


\section{HYDRAULIC CONDUCTIVITY CALCULATIONS}

PROGRAM SLUGT, VERSION 4.1, NOV. 1986

THIS PROGRAM CALCULATES MEAN TRANSMISSIVITIES FROM

SLUG-TEST DATA BASED ON TWO ANALYTICAL APPROACHES:

(1) METHOD OF COOPER, BREDEHOEFT AND PAPADOPULOS, 1967

(ARTICLE IN VOL.3, NO.1 OF WRR ENTITLED

"RESPONSE OF A FINITE DIAMETER WELL TO AN INSTANTANEOUS CHARGE OF WATER")

(2) METHOD OF BOUWER AND RICE, 1976 (ARTICLE IN

VOL. 12, N0.3 OF WRR ENTITLED

"A SLUG TEST FOR DETERMINING HYDRAULIC CONDUCTIVITY

OF UNCONFINED AQUIFERS WITH COMPLETELY OR PARTIALLY PENETRATING WELLS")

WELI NO.: 990

DATE OF TEST: $9 / 4 / 90$

PROJECT NO.: E221-002

CLIENT: MMES

SITE IOCATION : WAG-3

EDGE, INC. FIELD INVESTIGATOR: JAMES W. CARUTHERS

INPUT DATA ARE:

INNER CASING DIAMETER $=4.00$ INCHES

INNER SCREEN OR OPEN-HOLE DIAMETER = 4.00 INCHES

DIAMETER OF DRILLED HOLE $=8.25$ INCHES

IENGTH OF SCREEN OR INTAKE PORTION $=15.00$ FEET

DEPTH FROM STATIC IEVEL TO BOTTOM OF SCREEN $=10.73$ FEET

THICKNESS OF SATURATED AQUIFER ZONE $=15.00 \mathrm{FEET}$

DEPTH TO STATIC WATER LEVEL BELOW REF. POINT $=11.00$ FEET

ESTIMATED POROSITY OF GRAVEL PACK $=.20$

FAILING-HEAD INDEX = 0 ("I" IF FALIING,"0" IF RISING)

NUMBER OF DEPTH-TIME DATA POINTS $=32$

HO WAS COMPUTED FROM INTERCEPT OF PLOT OF LOG(H) VS. TIME

SUCCESSIVE COMPUTED

VALUES FOR HO

(FEET)

1.1288

1.1337 


\title{
HYDRAULIC CONDUCTIVTY CALCULATIONS
}

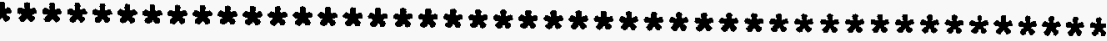 \\ METHOD OF BOUWER AND RICE \\ COMPUTED RESULTS USING DIAMETER OF DRILLED HOLE: \\ PERMEABILITY $=1.17 \mathrm{E}-06 \mathrm{FT} / \mathrm{SEC}$ \\ $=3.57 \mathrm{E}-05 \mathrm{CM} / \mathrm{SEC}$ \\ TRANSMISSIVITY $=1.76 \mathrm{E}-05 \mathrm{FT} * 2 / \mathrm{SEC}$
}

COMPUTED RESULTS USING DIAMETER OF CASING AND SCREEN:

$$
\text { PERMEABILITY }=8.90 \mathrm{E}-07 \mathrm{FT} / \mathrm{SEC}=2.71 \mathrm{E}-05 \mathrm{CM} / \mathrm{SEC}
$$

TRANSMISSIVITY $=1.33 \mathrm{E}-05 \mathrm{FT} * \star 2 / \mathrm{SEC}$ 


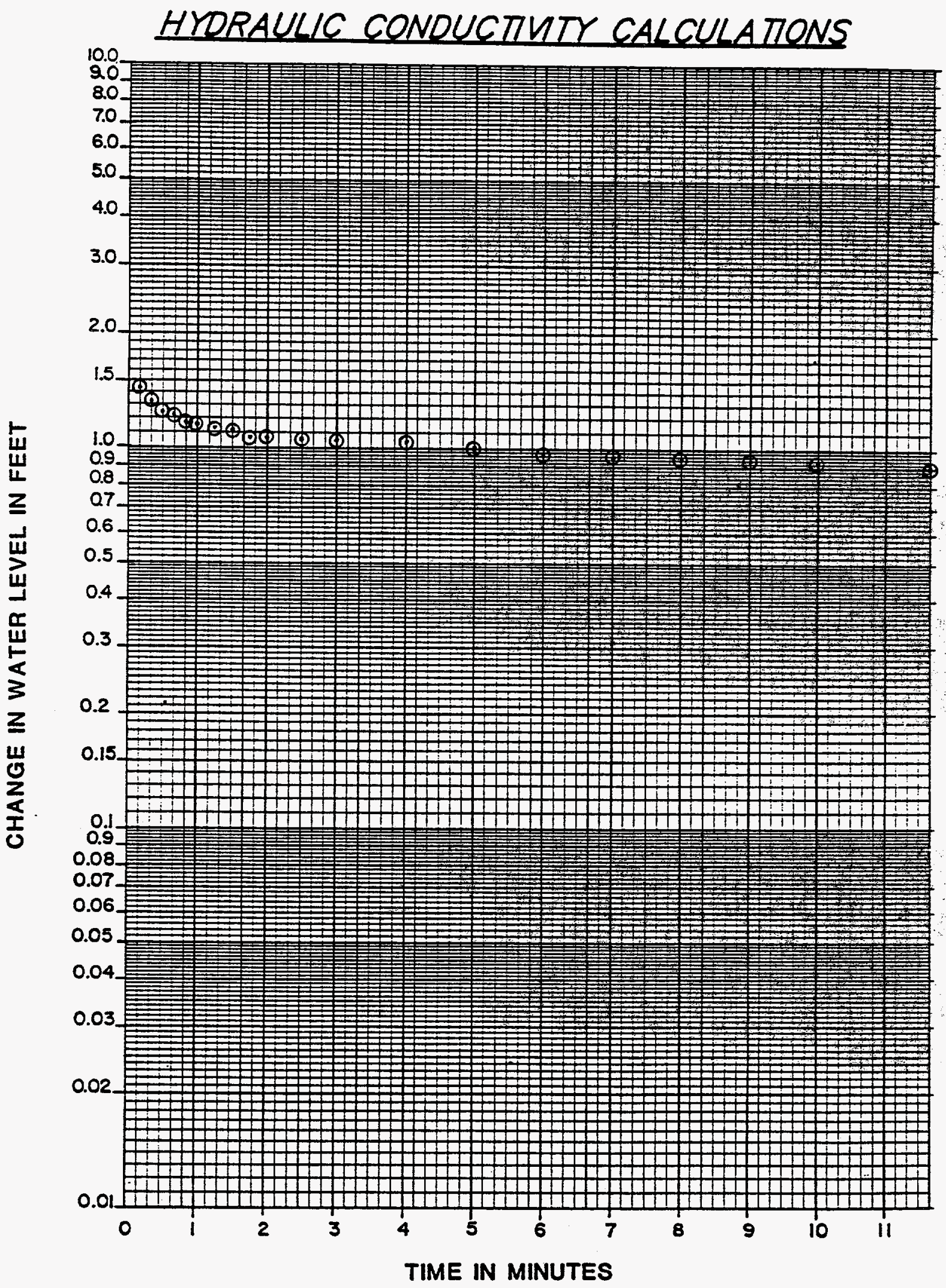




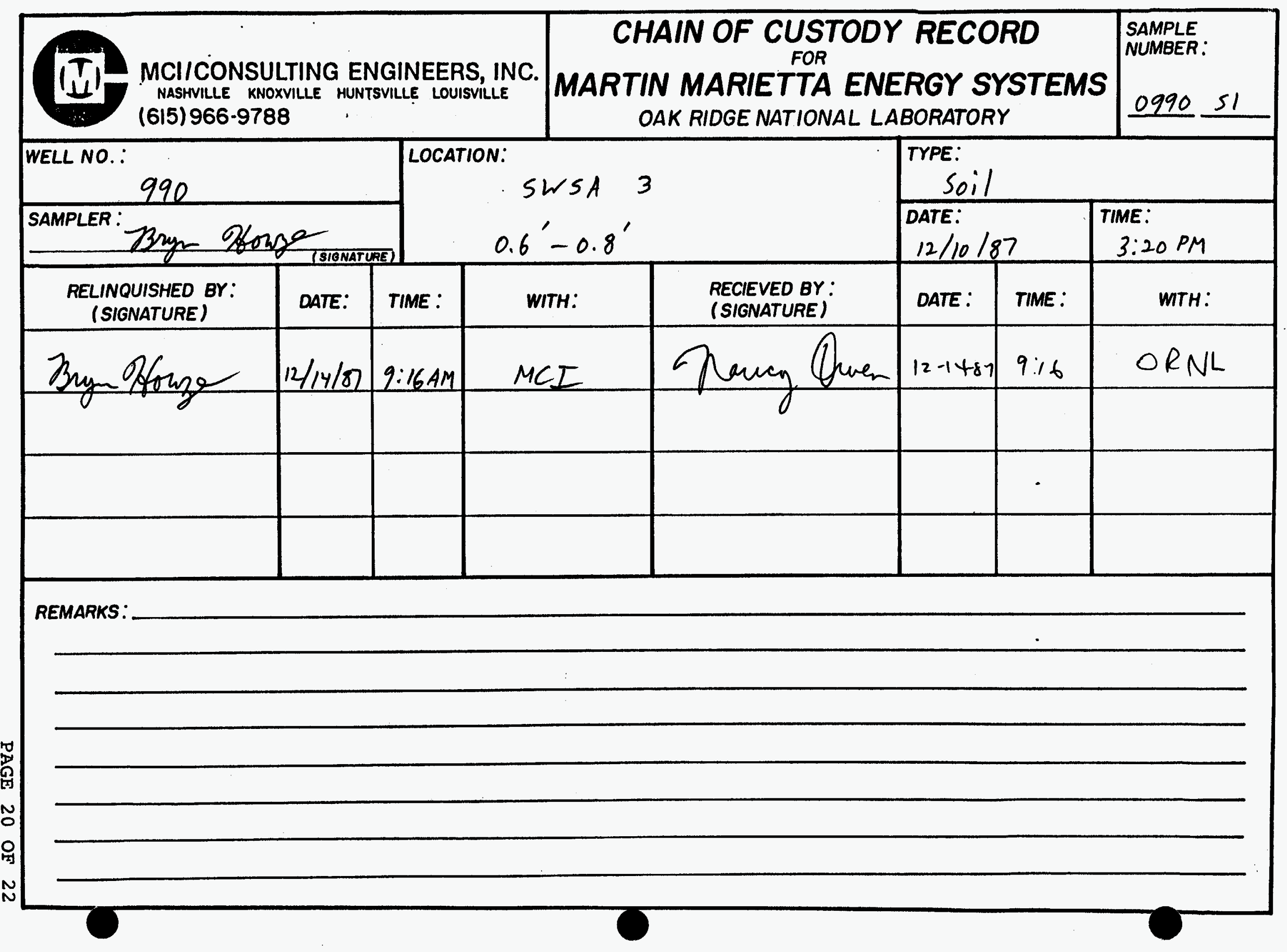




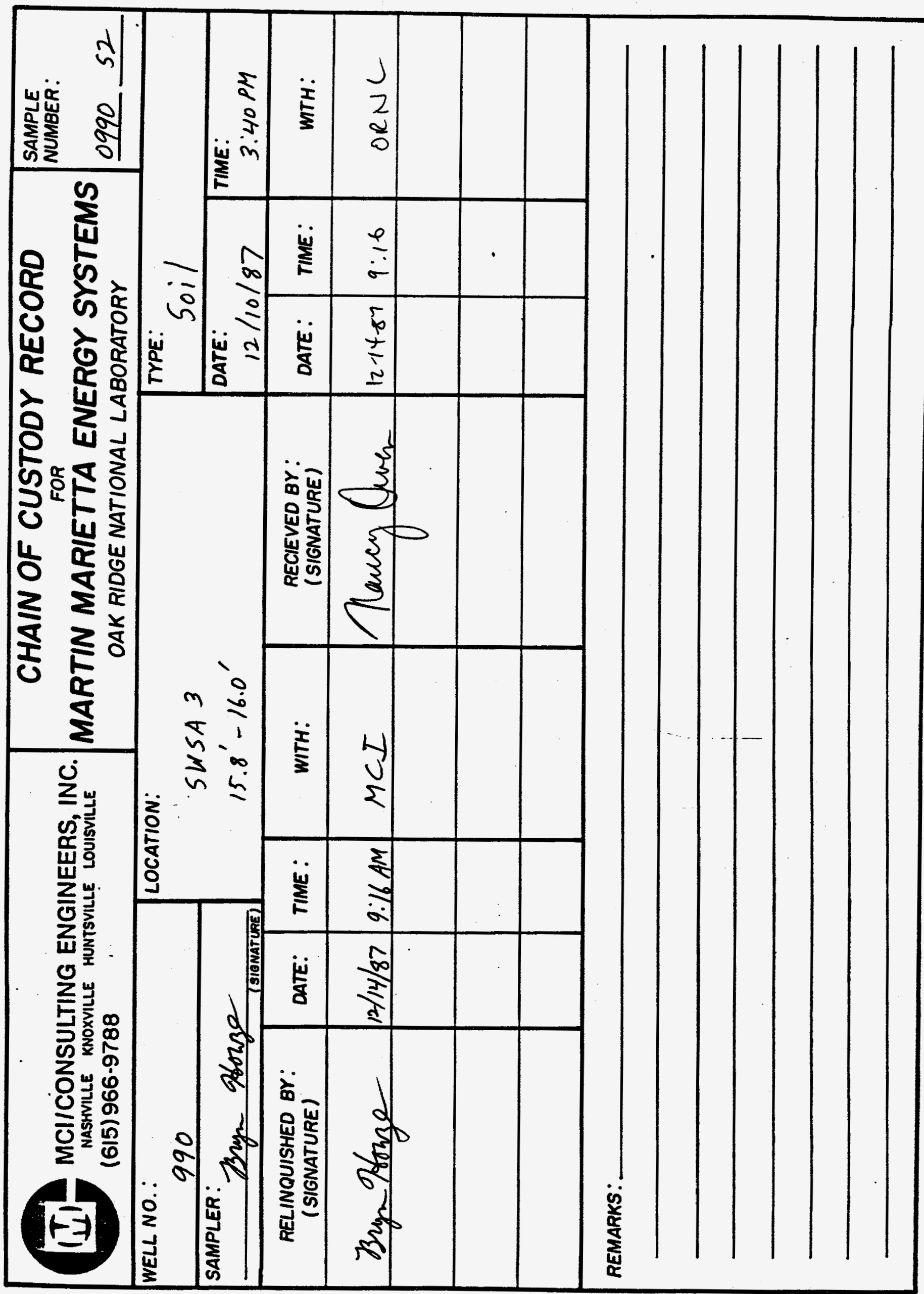




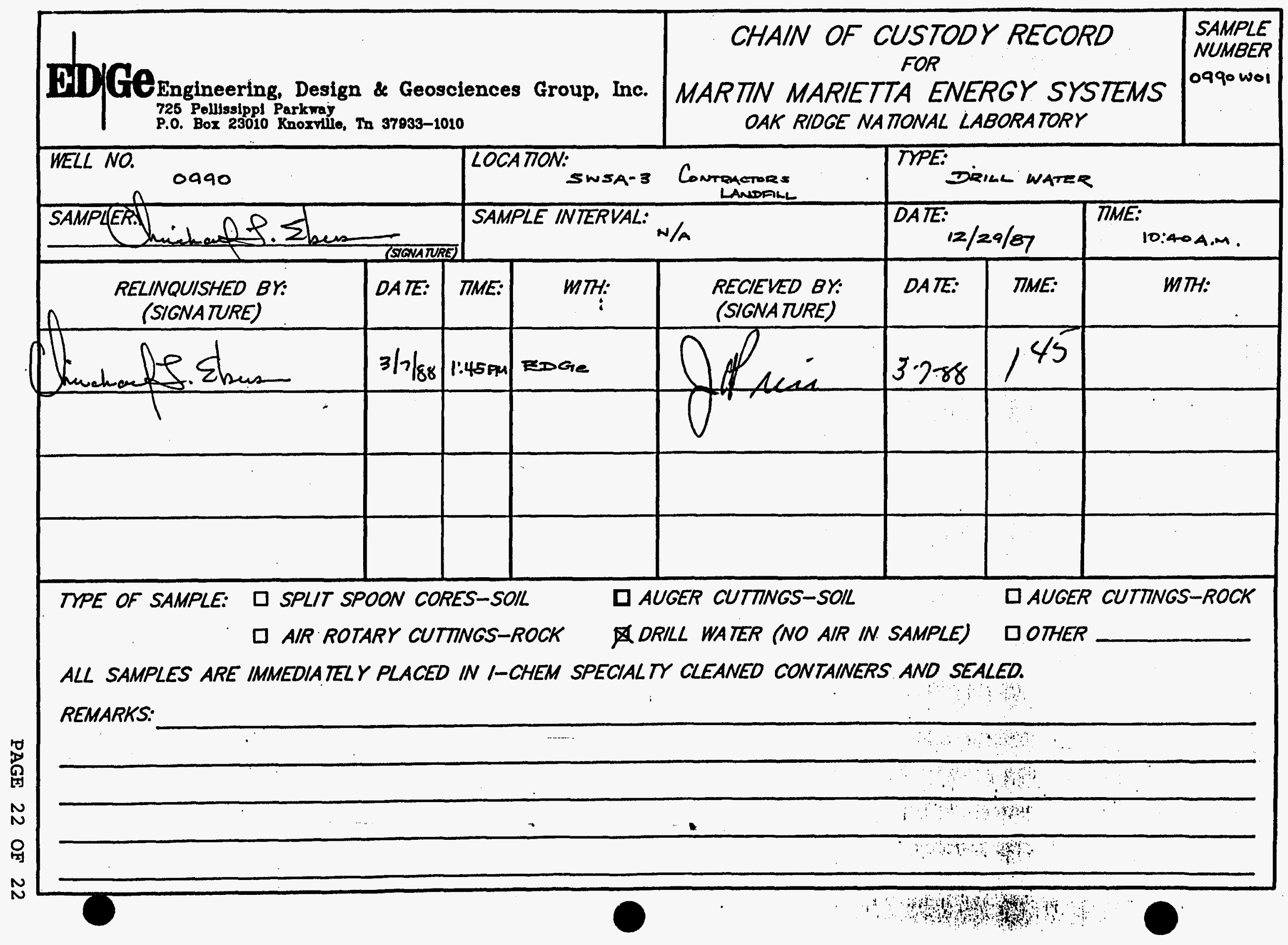




\subsection{General Information}

\subsection{Ne11 Location}

Monitoring well number 991 is located in WAG 3 . It is located on the north side of the contractors landfill. The location is shown on ORNL drawing number C3E20004 A075. Survey coordinates for this well are N 21,736.6362, E 25,051.4880 (X-10 grid) or latitude 35'-55'-00.48" and longitude 84'-19'-59.40". Coordinate data were provided by Martin Marietta Energy systems. The method used for conversion from X-10 grid to Tennessee-Lambert state Plane coordinates came from the publication "Tennessee Valley Authority Data Services Branch and Mapping Services Branch, Oak Ridge, Tennessee, DOE Plant Control, November 6, 1985, Field Book: ESS-3115, pp. 1-20." The latitude and longitude were calculated by Adams Craft Herz Walker Engineering, Inc., using methods from the U.S. Coast and Geodetic Survey Publication 62-4, "State Plane Coordinates by Automatic Data Processing."

\subsection{Drilling Information}

Well number 991 was drilled by A. L. Clark Drilling Services, Inc. A Schramm Rotadrill rig was used to drill this boring for monitor well installation under operation of Rick Pickel with the assistance of Leo Johnson. Drilling commenced on 10-26-87 and was finished on 11-24-87. Paragraph 2.4.1 includes a detailed discussion of the well installation and a well schematic is included on the well installation/ completion form. A synopsis of the drilling activity 
ERC / EDGE

Environmental

and Energy

Services Co.

follows. This information was typed directly from field notes and was edited only when necessary for clarification.

10-26-87 Mobilized drill rig to staked location and set up. Augered from 0.0 feet to 25.3 feet with 14-inch augers.

10-27-87 Ran in 25.3 feet of 10-inch surface casing and grouted.

10-28-87 Rigged up containment box and drilled with $85 / 8$ - inch tricone from 25.3 feet to 35 feet.

10-29-87 Repairs to diverter head.

10-30-87 Drilled with $85 / 8^{\prime \prime}$ tricone from 35.0 feet to 60.5 feet.

11-2-87 Blowing out hole.

11-3-87 Reamed boring from 25.3 feet to 60.0 feet with 9- inch bit.

11-4-87 Ran a 6 5/8-inch steel casing from 0.0 feet to 60.5 feet.

11-11-87 Drilled with 6-inch tricone from 60.5 feet to 85.0 feet.

11-13-87 Completed well with 15 feet of 2-inch stainless steel screen and 70.0 feet of 2inch stainless steel casing. Poured in sand and pelleted bentonite. Bentonite bridged at 35.0 feet.

11-16-87 steam cleaning 3/4" iron pipe at SWSA 6 . Ran 3/4" pipe into \#991 in an attempt to wash out bridged bentonite. Bentonite bridge was located at 35 ' Washed pipe through bridge at $3^{\prime}$ ' but most of bentonite still in place at bridge. Taped through 
ERC / EDGE

Environmental

and Energy

Services Co.

bentonite bridge to top of bentonite pellet seal at $60.5^{\prime}$. Put tremie pipe down to 55' and grouted through with grout - put in 10 bags - pulled pipe, only lower $I^{\prime}$ of pipe had grout on it. No visible sign of grout in annulus.

11-19-87 Bryn Houze checked Well \$992 for the presence of grout and pH of water. Hand bailer dropped without obstruction to 47.1 , $\mathrm{pH}$ of water was 8.3 .

11-24-87 steamed cleaned 5 joints (53') of 3/4" iron pipe, rinsed with alcohol and deionized water. Wrapped in plastic and took to Well \#991. A.L. Clark ran in four joints of 3/4" tremie pipe. Pipe stopped at bentonite bridge at $35^{\prime}$. Tried to wash pipe through bridge. Disconnected water and made two attempts to push tremie pipe through bridge. Pulled pipe out, loaded it on the water truck and left. A. I. Clark insisted that the tremie pipe was hitting a centralizer and grout at $35^{\prime}$. Bentonite was observed sticking to the end of the tremie pipe. After A. L. Clark left, the hole was taped (bentonite bridge e35) and bentonite with some shale cuttings was observed sticking to the weighted end of the tape.

This well was logged by ERC Environmental and Energy Services Co., Inc., hydrogeologists Michael I. Ebers and John W. Anderson. All well construction materials and 
supplies were from Martin Marietta Energy Systems approved batches. The batch origin of individual items is shown on the included Monitoring Well Materials Certification form.

\subsection{Technical Information}

\subsection{Decontamination Procedures}

The drilling rig, down hole tools, surface casing, stainless steel screen, stainless steel casing, centralizers, and stainless steel silt trap underwent the cleaning decontamination procedures outlined in the drilling specifications (Release specific Technical Directions for Regulatory compliance Monitoring Wells Phase 1, Oak Ridge National Laboratory, Oak Ridge, w.o. K-4147, April 1987, pgs. 2-4). A checklist of the cleaned materials is included with this data package.

\section{$2.2600109 y$}

WAG 3 is located in Melton Valley which is in the Valley and Ridge Physiographic Province of East Tennessee. WAG 3 is underlain by limestone, siltstone and shale of the Middle Ordovician Chickamauga Group. The Chickamauga Group consists of eight units, designated by letters "A" to "H" (Stockdale, 1951). WAG 3 is underlain by units E, F, G and H. These units consist of thin bedded nodular limestone with clay and shale partings. A portion of unit $H$ and unit $F$ consists of calcareous siltstone alternating 
with beds of olive gray to maroon shale. Strike and dip varies from $N 45^{\circ} \mathrm{E}$ to $\mathrm{N} 55^{\circ} \mathrm{E}$ and $25^{\circ}$ to $35^{\circ}$ southeast, respectively.

\subsection{Sample collection}

No samples were collected during drilling.

\subsection{Installation and Development}

\subsubsection{Installation}

This was a "Type B" well. A 14-inch diameter boring was augered from ground surface to bedrock (25.3 feet). A 10-inch diameter string of decontaminated steel surface casing was installed and tremie grouted in place. The surface casing minimizes potential cross contamination between the regolith and bedrock water bearing zones. The air rotary method was then used to drill an 8-inch diameter boring to a depth of 60.5 feet. The boring was reamed to $85 / 8$ " diameter from 25.3 feet to 60.5 feet and a 6 5/8-inch casing was installed from 0.0 feet to 60.5 feet. The boring was deepened to 85.0 feet with a 6-inch tricone bit. A 2-inch diameter stainless steel silt trap was installed from 84.8 to 85.0 feet. Above the silt trap, a 4-inch diameter stainless steel screen was installed from 70.0 feet to 85.0 feet. A 2-inch diameter stainless steel casing was installed from the top of the screen at 70.0 feet and extending 2.44 feet above ground surface. A sandpack was then poured into 
the annular space from 62.0 to 85.0 feet, with a $1.5-$ foot bentonite seal poured into the annular space above the sandpack from 60.5 to 62.0 feet. The annular space from the top of the bentonite seal to the surface was tremie grouted with a cement/bentonite slurry. A detailed schematic of the well is included on the well installation/completion form.

\subsubsection{We11 Development}

Well number 991 was developed to remove drill cuttings, silt, and other fines. The monitoring well was developed using a Geoguard pump with an air compressor. All pumps were cleaned prior to use according to specified cleaning procedures (see Paragraph 2.1). The well was developed until a measured total of 225 gallons of water had been evacuated and the clarity of the discharge water was approved by the company representative. The final turbidity value measured at completion was 1.0 NTU's. A development form showing the exact method of development and other pertinent data is appended.

\subsubsection{Installation of Dedicated Monitoring Well Pump}

After the well was developed, a Geoguard Model No. 5614 dedicated monitoring well pump was installed on 4-24-90 at a depth of 81.3 feet below ground surface. These pumps are decontaminated at American sigma and are sent prepackaged. A copy of the pump certification is kept on file at ORNL. 
ERC / EDGE

Environmental

\subsection{Hydraulic conductivity Testing}

Well number 991 was tested for the determination of hydraulic conductivity of the aquifer in the vicinity of the well screen. This was accomplished by instantaneously adding a known quantity of water to the monitoring well and measuring the recovery of the water level over time. The changing water levels were measured using a Druck 15 psig pressure transducer and an Omnidata Datapod II data recorder. The hydraulic conductivity value of $6.76 \times 10^{-5} \mathrm{~cm} / \mathrm{second}$ (shown as permeability on the hydraulic conductivity calculations printout attached) was calculated using the Bouwer and Rice method. A computer printout of the hydraulic conductivity calculations is included in this data package.

\subsection{Jonconformance Reports}

Two nonconformance reports have been filed for this well due to improper grouting and centralizer installation. Copies of the two reports are attached. 
ERC / EDGE

Environmental

and Energy

WELL NO. 991

Services Co.

\section{PRE-DRILLING CHECKLIST FOR MONITORING WELLS}

\section{PRE-DRILLING TASKS}

1. EXCAVATION PERMIT OBTAINED.

2. ALL EQUIPMENT HAS BEEN CLEANED BEFORE DRILUNG.

3a. SCREEN AND CASINGS HAVE BEEN WASHED, STEAMED, RINSED WIH DE-IONIZED OR DISTILED WATER, RINSED WTH ISOPROPN ALCOHOL WPAPPED WTH PROTECTVE COVERING AND STORED OFF THE GROUND.

36. PRE-PACKAGEO SCREENS, CASINGS ANO CENTRALIZERS MERE USED.

4. WORK AREA FOR SAMPLE EXAMINA IION COVEREO WTH CLEAN PQLYTHYENE.

5. CLEAN KNIVES, GLOVES, SAMPLE JARS ANO LABEZS ON-HAND.

6. POL YETHIENE COVER IN PLACE OVER HOLE. ADOIMONAL NOTES/OBSERVA TONS:

\begin{tabular}{|c|c|}
\hline \multicolumn{2}{|c|}{ COMPLIANCE } \\
\hline$D A T E$ & $\mathbb{N} / \pi / A<S$ \\
\hline $10-26-87$ & $\mu E$ \\
\hline $10-26-87$ & MUE \\
\hline$N / A$ & \\
\hline
\end{tabular}

11-12-87 NUE 10-26-87 ME 10-26-87 MUE 10-26-87 ME

\section{AOOIRONAL NOTESTOQSERVATONS.}

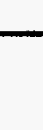


ERC / EDGE

Environmental

and Energy

WELL No. 991

Services Co.

DECONTAMINATION CHECKLIST

DRILLING EQUIPMENT

\begin{tabular}{|c|c|c|c|c|c|}
\hline EQUIPMENT & SCRAPE & $\begin{array}{l}\text { STEAN } \\
\text { CLEAN }\end{array}$ & $\begin{array}{l}\text { STEAM } \\
\text { RINSE }\end{array}$ & $\begin{array}{c}\text { ISOPROPL } \\
\text { ALCOHOL } \\
\text { RINSE }\end{array}$ & $\begin{array}{c}\text { DEIONIZED } \\
\text { WATER } \\
\text { RINSE }\end{array}$ \\
\hline$R / G$ & $x$ & $x$ & $x$ & $N / A$ & $N / A$ \\
\hline AUGERS & $x$ & $x$ & $x$ & $x$ & $x$ \\
\hline BITS & $x$ & $x$ & $x$ & $x$ & $x$ \\
\hline ROOS & $x$ & $x$ & $x$ & $x$ & $x$ \\
\hline SAMPLERS & $x$ & $x$ & $x$ & $x$ & $x$ \\
\hline PIPES & $x$ & $x$ & $x$ & $x$ & $x$ \\
\hline WORK TOOLS & $x$ & $x$ & $x$ & $x$ & $x$ \\
\hline AUGER PINS & $x$ & $x$ & $x$ & $x$ & $x$ \\
\hline & & & & & \\
\hline & & & & & \\
\hline & & & & & \\
\hline & & & & & \\
\hline
\end{tabular}

OBSERVER SIGNATURE/OATE Shmaha $\frac{\text { Michael L. Ebers }}{1 / 26 / 87}$ 


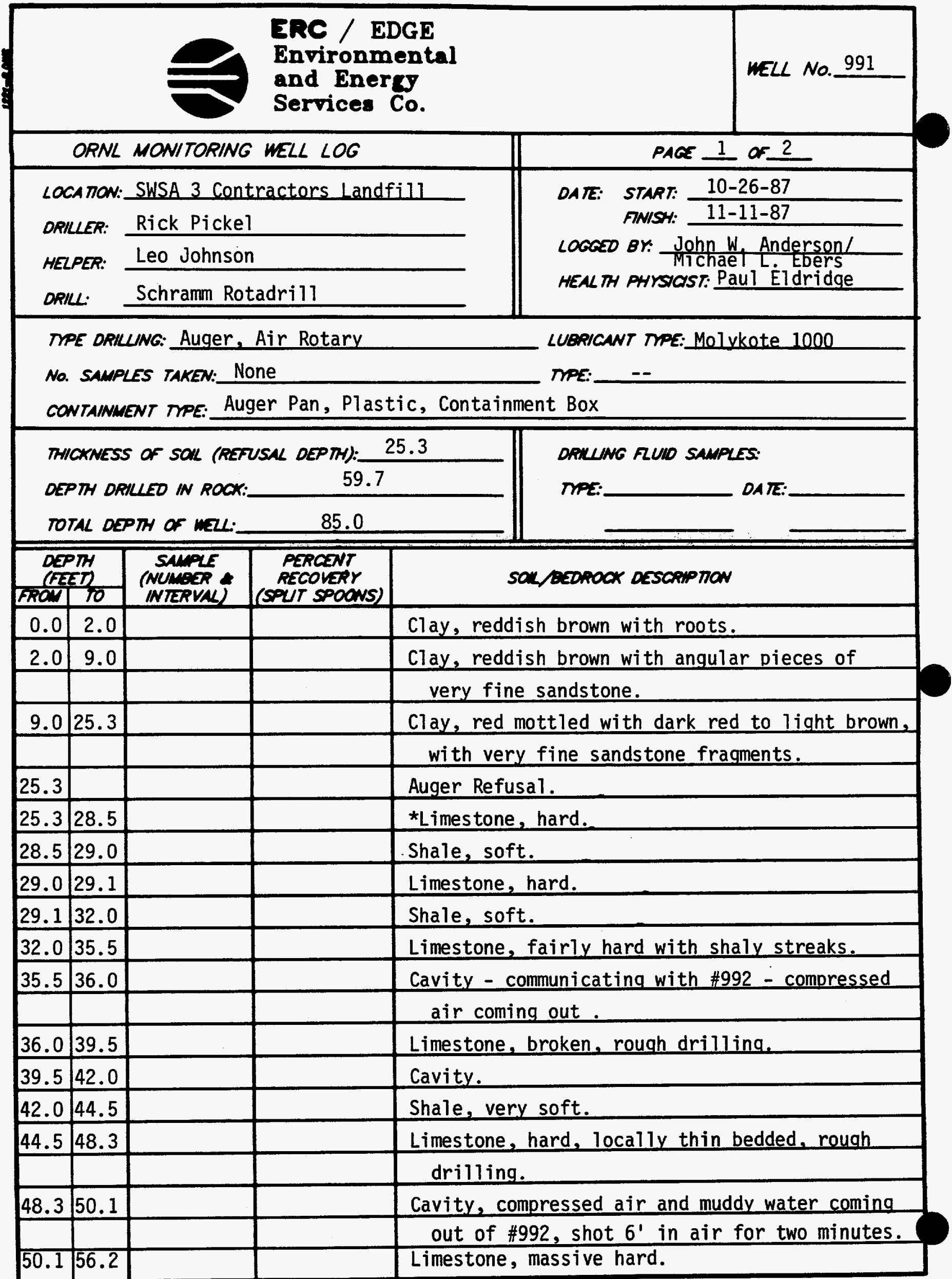




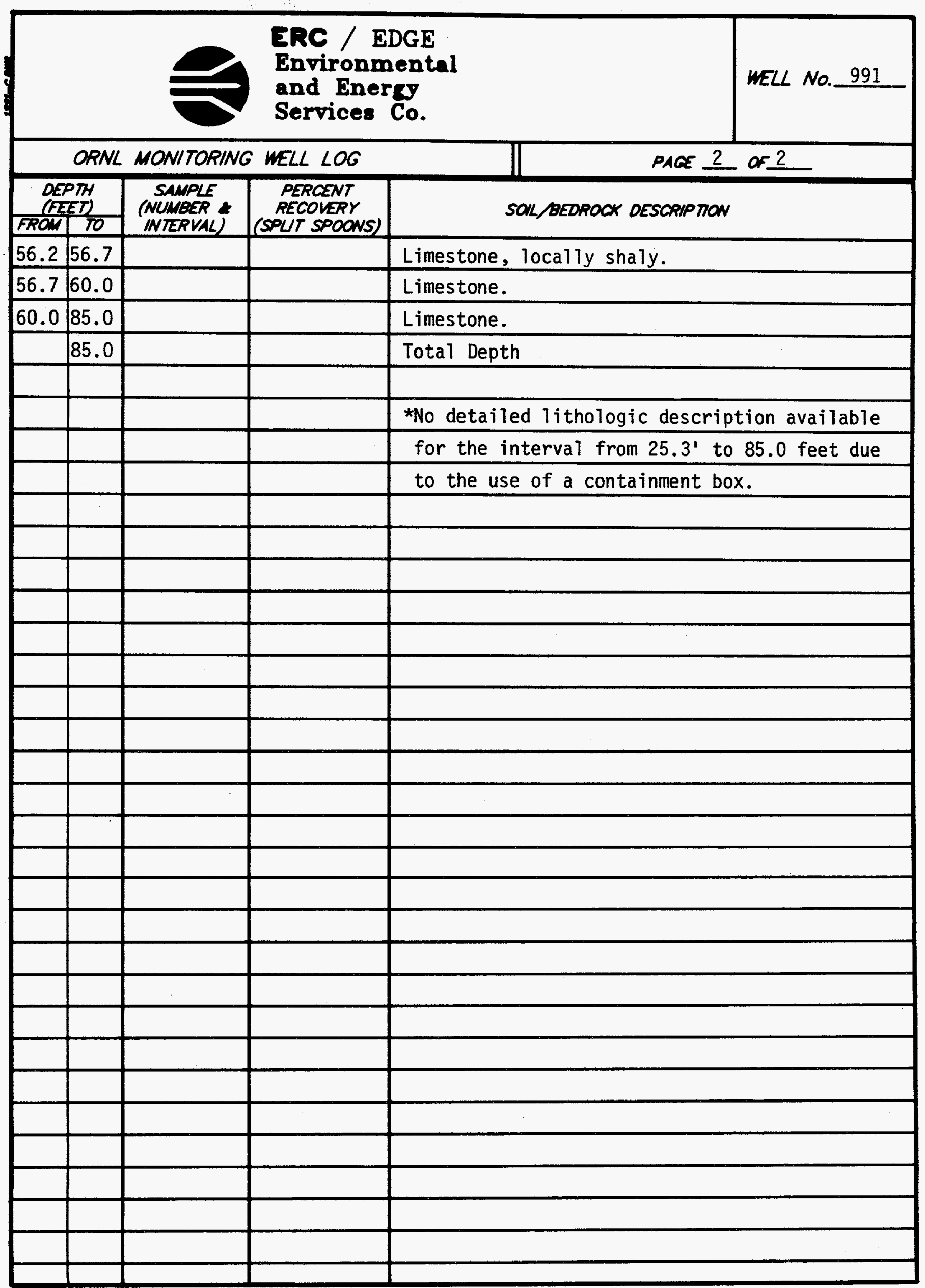

PACE 11 of 22 


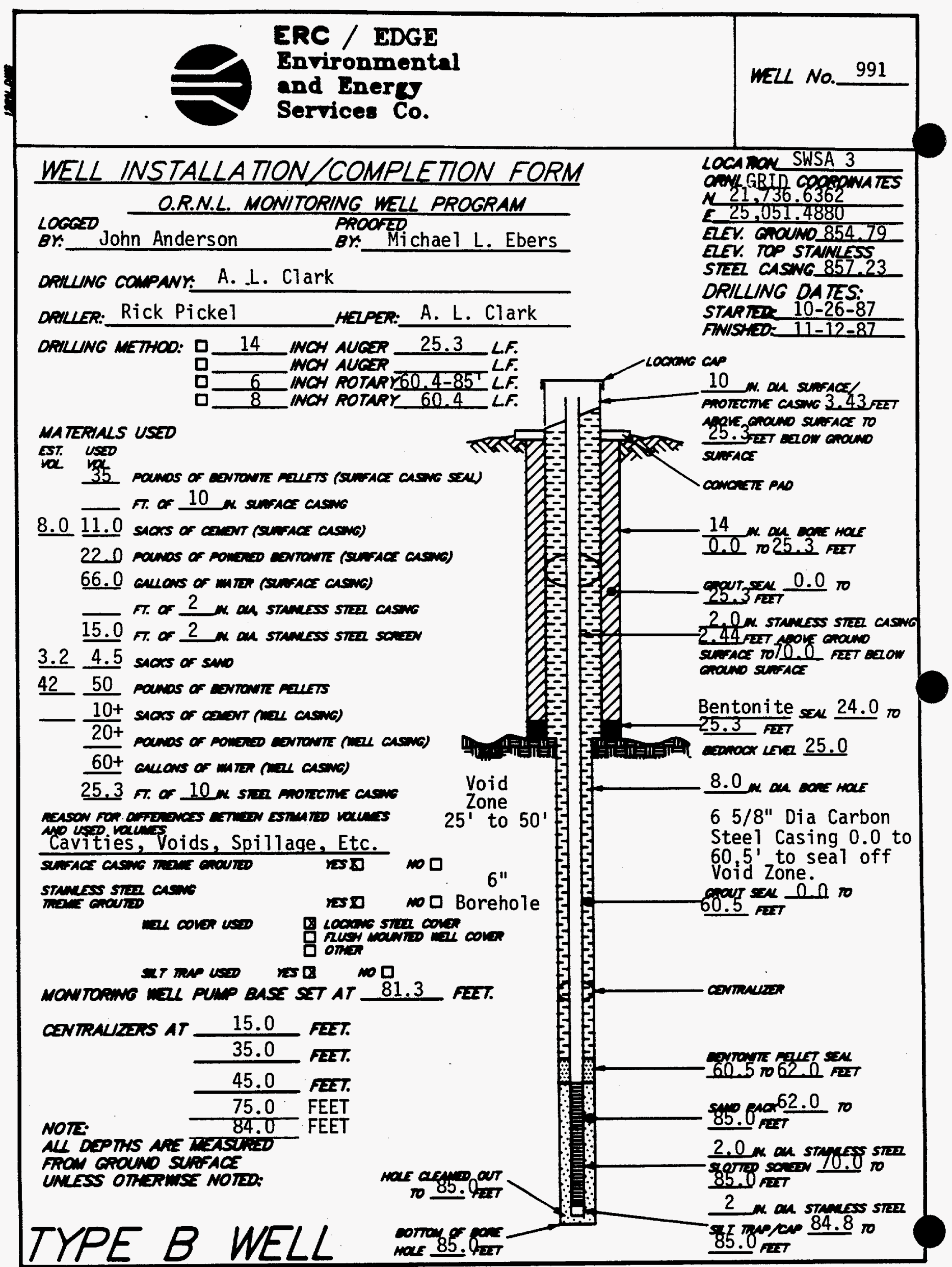

PAC 12 of $\underline{22}$ 


\section{MONITORING WELL MATERIALS CERTIFICATION}

\begin{tabular}{|c|c|c|}
\hline ITEM/MA TERIAL & DATE USED & BATCH NUMBER \\
\hline \multirow{2}{*}{ SAND } & $10-27-87$ & 02 \\
\hline & $11-12-87$ & 02 \\
\hline \multirow{2}{*}{ BENTONITE } & $11-10-87$ & 02 \\
\hline & $11-12-87$ & 02 \\
\hline $\begin{array}{lll}\text { STAINLESS STEEL SCREEN } & \text { (PREPACKACED } & \text { HES } \\
\text { NO }\end{array}$ & $11-12-87$ & 05 \\
\hline (PREPACKAGED $\left.0 \begin{array}{c}\text { PES } \\
\text { NO }\end{array}\right)$ & $11-12-87$ & 05 \\
\hline STAINLESS STEEL CENTRALIZERS (PREPACKAGED 0 VES') & $11-12-87$ & 05 \\
\hline STAINLESS STEEL CAPS (PREPACKAGED 0 VES) & $11-12-87$ & 05 \\
\hline (PREPACKAGED D NES) & $4-24-90$ & 05 \\
\hline \multirow{2}{*}{ GROUT } & $10-27-87$ & 11 \\
\hline & $11-10-87$ & 11 \\
\hline \multicolumn{3}{|l|}{ WELL COVERS } \\
\hline SURFACE CASING & $10-27-87$ & 02 \\
\hline
\end{tabular}

COMMENTS:

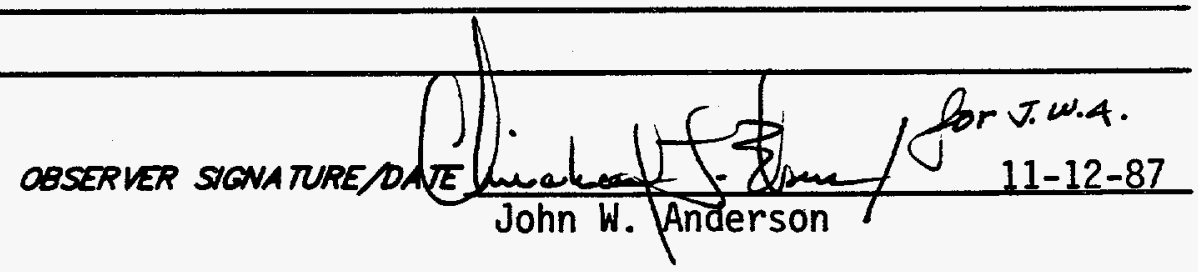

PAGE 13 of 22 


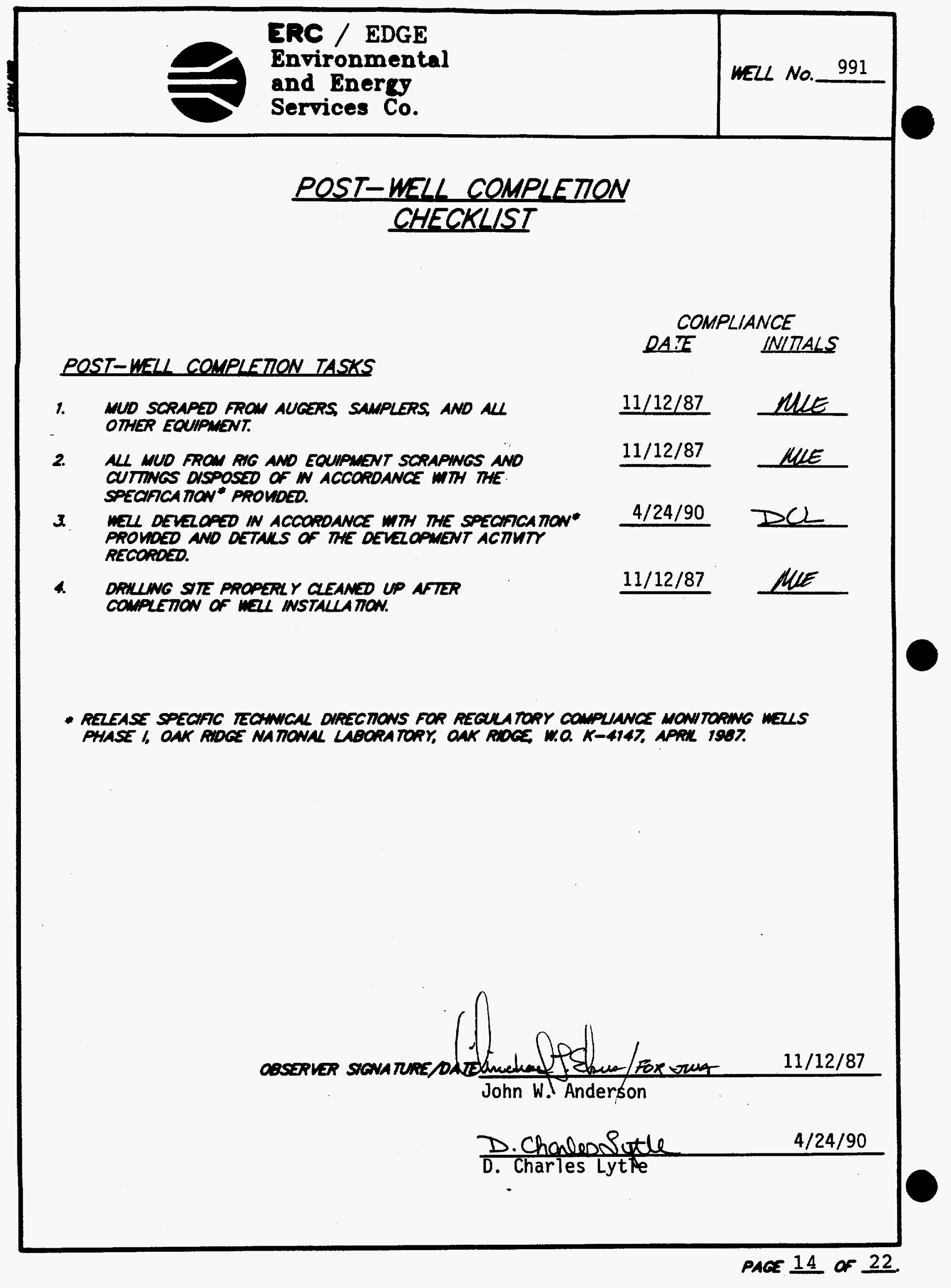




\section{ERCE}

Environmental

and Energy

Services Co.

WELL NO. 991

LOCA TON:WAG-3

\section{MONITORING WELL \\ DEVELOPMENT FORM}

DEVELOPMENT DETAILS

METHOD OF
DEVELOPMENT: Surging and Pumping

DEVELOPMENT

BEGAN DATE: $\quad 4 / 19 / 90$ TME:

DEVELOPMENT

ENDING DATE: $\quad 4 / 24 / 90$

DEVELOPMENT

OBSERVED BY:

D. Charles Lytle

ONE WEL VOLUME: 15.4 GALLONS

TOTAL GALLONS PUMPED: 225 TOTAL WELL VOLUMES PUMPED: 14.6

INITAL PH: 7.6 FNAL PH: 7.8

INITAL CONDUCTUTY ( $\mathrm{KS} / \mathrm{cm})$ : 638 FNAL CONDUCTVTY $(\mu \mathrm{s} / \mathrm{cm}): 673$

DESCRIPTION OF INITAL TURBIOIT: Slightly Cloudy

DESCRIPTION OF FINAL TURBIDITY: CTear

FINAL MEASURED TURBIDITY:_ $\quad 1.0$ NTU'S

WELL APPROVED BY: R. C. Williams MMES

ODOR

OF WATER: None

WATER $\triangle$ GROUNO SURFACE

DISCHARGED $\square$ STORM SEWERS

TO:

$\square$ DRUNS

口 TANK TRUCK

STORAGE TANKS

口 OTHER

INITAL PRE-DEVELOPMENT WATER DEPTH:

45.6 feet from ground surface.

\section{DEVELOPMENT OBSERVATIONS}

OBSERVER SIGNATURE/OATE D.Chales \&yele

$4 / 24 / 90$

D. Charles Lytie 


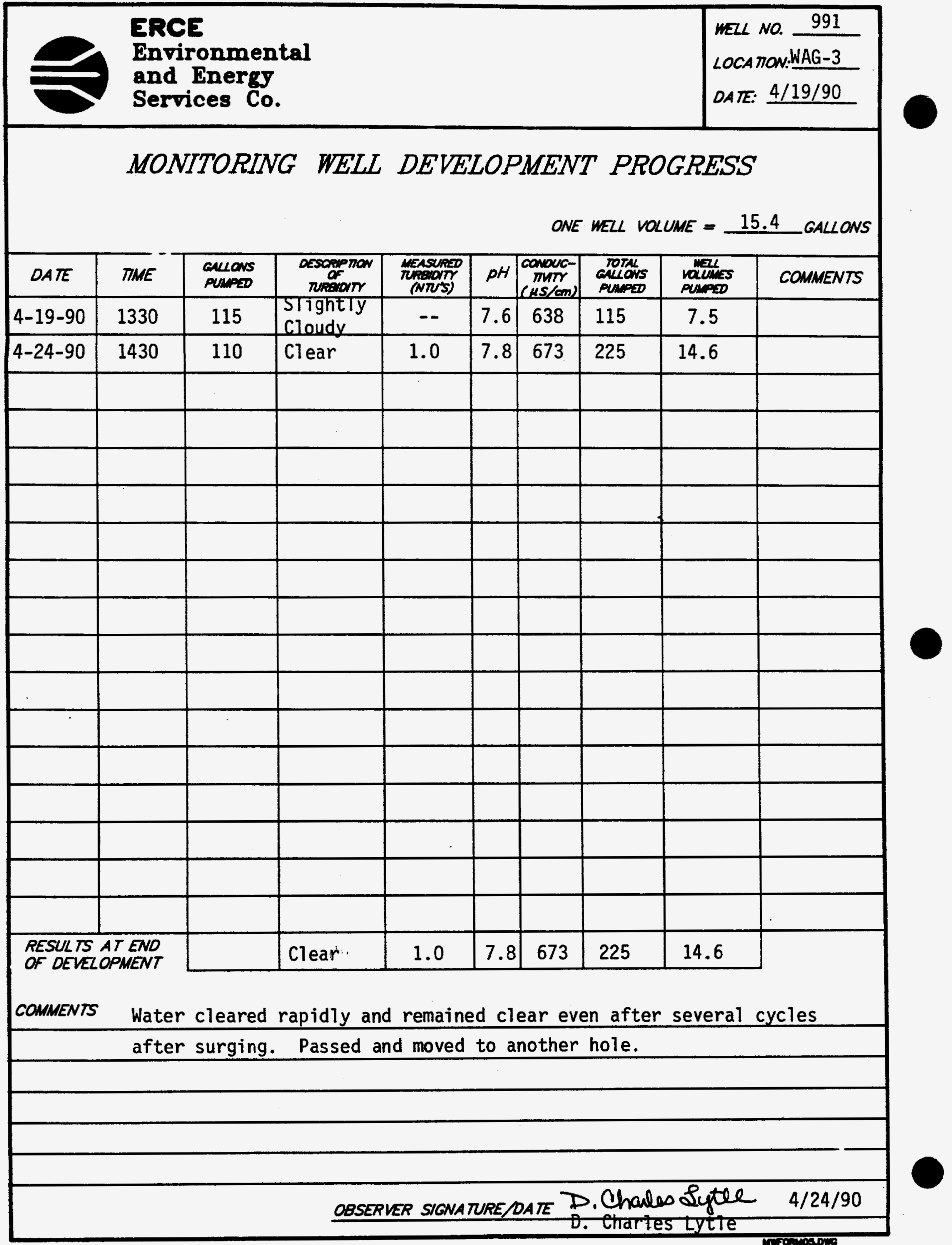

PAGE 16 of 22 . 


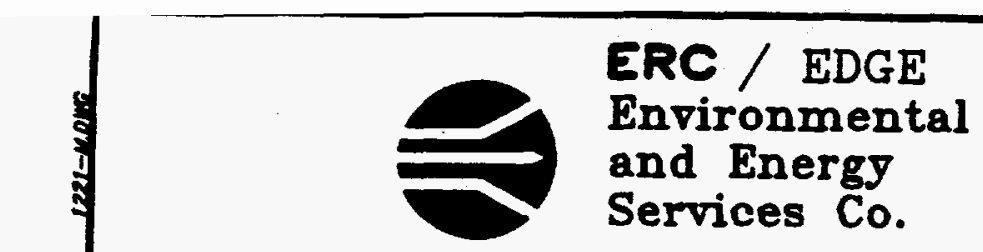

\title{
HYDRAULIC CONDUCTIVTY CALCULATIONS
}

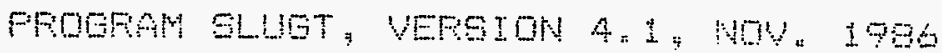

THIE FFOGEAM CALOULATES MEAN TRANGMISSTYTTES FFOM

SLUE-TEST DATA EAEED ON TWO ANALYTICAL APPEOACHES:

(1) METHOD OF CODPER, EFEDEHDEFT AND FAFADOFULDS, 1967

CASTIOLE IN VOL. $\triangle$, NO. $\triangle$ OF WFF ENTITLED

"FESFDNSE DF A FINITE DIANETEF WELL TO AN INSTANTANEOUS CHAEGE OF WATEF" ?

(2) METHOD OF EOUUER AND RICE, 1976 (AFTICLE IN

VOL. 12, NO.S OF WFF ENTITLED

"A SLUE TEST FOF DETERMINING HYDFALIL CONDUUTIUTTY

OF UNCONE INED AOUIFEFS WITH COMPLETELY OF FAFTIALLY

PENETFAT INE WELLE",

WELL NO: : 299

DATE OF TEST: $5 / 15 / 90$

FROJECT NO: E221-DO2

CLIENT: MHES

STTE LOCATION: WAG-

EDGE; INE. FIELD INUESTIGATOF: Eruce MEMaster

INFUT DATA ARE:

INNEF CASING DIAMETEF: $=2.00$ INCHES

INNEF SCREEN DE OFEN-HOLE DIAMETEF $=2$.QD INCHES

DIAMETEF: OF DFILLED HOLE = $8.6 \Omega$ INCHES

LENETH OF SCREEN OF INTAKE FORTION $=15.00 \mathrm{FEET}$

DEFTH FFOM STATTO LEVEL TO EOTTOM OF SCFEEN $=45.60$ FEET

THICKNESS OF SATUFATED AGUIFEF ZONE = 15. QQ FEET

DEFTH TO STATIE WATEF LEVEL BELOW REF. FOINT = .9P FEET

ESTIMATED FOFOSITY OF GFAVEL PACK $=.20$

FALLING-HEAD INDEX $=1$ " 1 " IF FALLING, "D" IF FISYNG)

NUMEEF QF DEFTHTIME DATA FOINTS = 32

HO WAS COMPUTED FFOM INTERCEFT OF FLOT DF LOG (H) VS. TIME

SUCCESSIVE COMFUTED

VALUES FOF HD

(FEET)

10.5062

10.5 .556

PAGE 17 of 22. 


\section{HYDRAULIC CONDUCTIVTY CALCULATIONS}

\begin{tabular}{|c|c|c|}
\hline TIME & DEFTH TO WATEF & HEAD \\
\hline sec & (FEET) & (FEET) \\
\hline $10.0 B$ & 19,010 & 9.058 \\
\hline 20.00 & 9.610 & 0.630 \\
\hline 30.00 & $9.39 \%$ & 9.41 .8 \\
\hline 40.60 & 9.210 & 9.230 \\
\hline 50.98 & $\because .050$ & $e .870$ \\
\hline $6 \% .00$ & 8.910 & 7.950 \\
\hline $75.0 D$ & $\theta .680$ & $7.7 a n$ \\
\hline 90.00 & 8.450 & 7.470 \\
\hline $1 Q 5: O B$ & 0.230 & 7.256 \\
\hline 1.20 .00 & $\theta: 010$ & 7.090 \\
\hline 150.00 & 7.590 & 6.610 \\
\hline 100.00 & 7.170 & 6.190 \\
\hline 240.00 & 6.420 & $5: 440$ \\
\hline 300.00 & 5.750 & 4.770 \\
\hline 360.00 & $5=150$ & 4.170 \\
\hline 420.00 & 4.630 & 3.650 \\
\hline 490.00 & 4.180 & 5.200 \\
\hline 540.00 & 3.760 & 2.790 \\
\hline $600=00$ & 3.400 & $2.42 \mathrm{D}$ \\
\hline 720.00 & 2.800 & 1.920 \\
\hline $34 \pi .20$ & 2.340 & 1.360 \\
\hline 960.00 & 1.990 & 1.010 \\
\hline 1080.00 & 1.7 .50 & .750 \\
\hline 1200.00 & 1.510 & -530 \\
\hline $1220=0 D$ & 1.340 & .360 \\
\hline 1.440 .00 & 1.220 & $=240$ \\
\hline 1560.00 & 1.110 & .130 \\
\hline 1690.00 & 1.050 & .070 \\
\hline 1800.00 & 1. 0.50 & .050 \\
\hline 1920.00 & 1.030 & .050 \\
\hline $2040=00$ & 1.010 & $n 030$ \\
\hline 2160.00 & 1. . 0.10 & .030 \\
\hline
\end{tabular}

METHOD DF BOUWEF AND RICE

COMPUTED FESULTS USING DIAMETEF OF DFILLED HOLE:

FEFMEAEILITY = 2.22E-DE FT/SEC =6.76E-DE CM/SEC

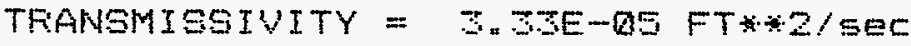




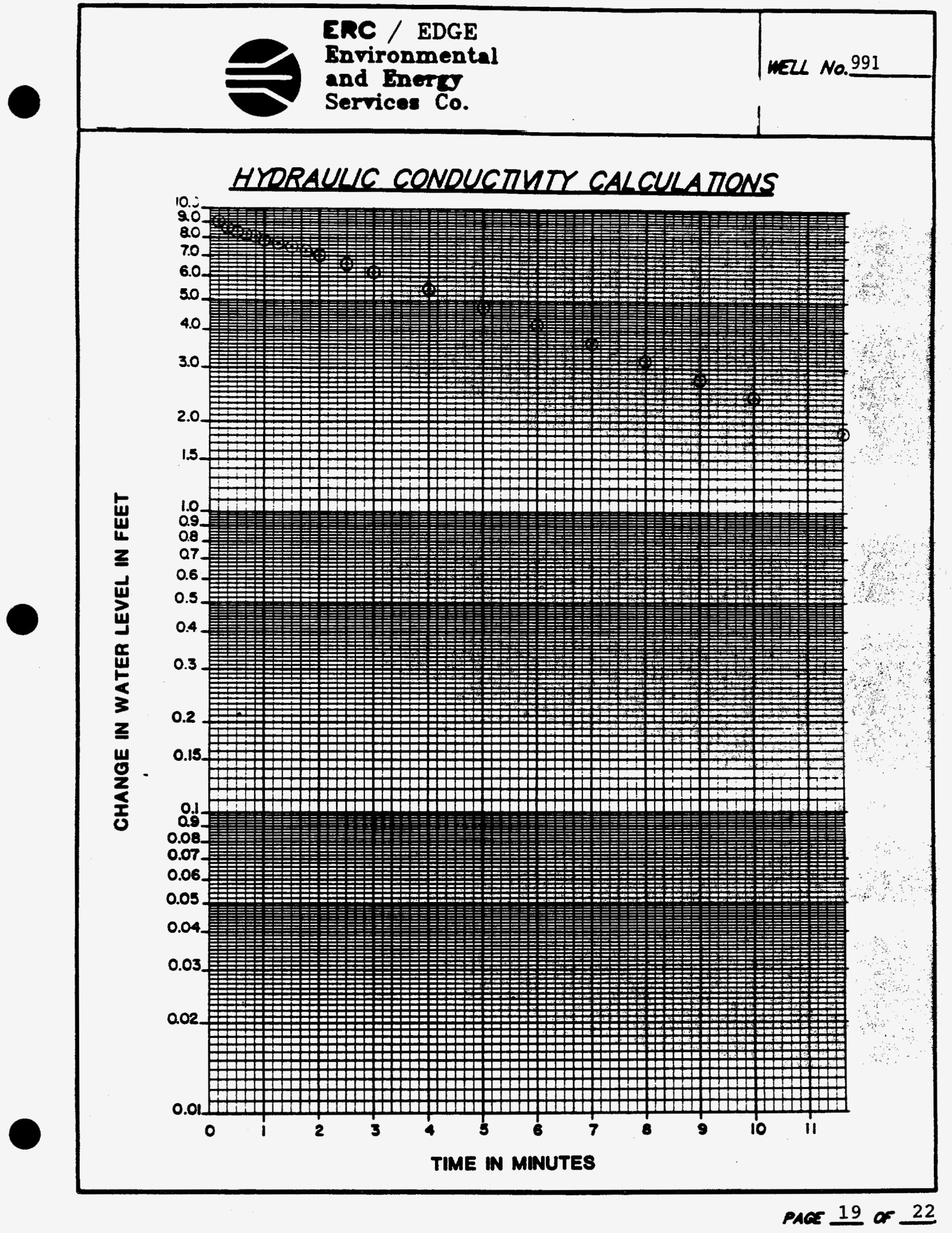




\section{NONCONFORMANCE REPORT}

ISSUE DATE: August 10,1988

DATE OF NONCONFORMANCE: April 1988

DESCRIPTION OF NONCONFORMANCE:

During April, 1988; A. L. Clark Drilling Services, Inc. ran a tremie line in well \#991 and grouted the annular space between the $65 / 8^{\prime \prime}$ diameter steel casing and the 2" diameter slainless steet casing. Neither A. L. Clark Drilling Services or Construction Engineering informed MCI Consultant Engineers that this was being done. Since MCI was not present when the grouting took place, it cannot confirm whether or not the tremie pipe was placed to the proper depth or how many sacks of grout were used. A. I. Clark III, on April 26, 1988, was unable to recall the length of tremie pipe or the quantity of grout used. The hole had an unwanted $2^{\prime \prime}$ bentonite bridge at $35^{\prime}$. If the tremie pipe was not pushed thru this bridge prior to grouting, the annular space (between the 2" s.s. casing and the $65 / 8$ " diameter steel casing) is still open from 35' down to $60^{\prime}$.

POSSIBLE DETRIMENTAL EFFECTS TO WEZL QUALTY:

Possible vertical contamination pathway (Tope of bentonite seal is at $65^{\prime}$ )

COMMENTS:

\begin{tabular}{|l|l|}
\hline OBSERVER OF NONCONFORMANCE: & DATE: \\
\hline $\begin{array}{l}\text { REPORTED BY: } \\
\text { Michael L. EberS }\end{array}$ & DATE: \\
\hline DISTRIBUTION & AuguSt 10, 1988 \\
\hline DATE SUBMITIED:
\end{tabular}

PROECT MANAGER:

Jill Mortimore

August 12, 1988

DATE SUBMITIED:

ENGNEER:

August 12,1988 
NONCONFORMANCE REPORT

ISSUE DATE: $12 / 10 / 87$ DATE OF NONCONFORMANCE: $11 / 13 / 87$

DESCRIPTION OF NONCONFORMANCE:

Installed Centralizers every ten feet above screen-every 20 feet is specified.

POSSIBLE DETRIMENTAL EFFECTS TO WEL QUALTR:

This helped cause the subsequent bridging of the bentonite pellet seal. Numerous attempts were made to remove bridge. Well grouting delayed at least a month, during which time a contaminant pathway existed.

COMMENTS:

OBSERVER OF NONCONFORMANCE:

DATE:

John Anderson

$12 / 10 / 87$

REPORTED BY:

DATE:

John Anderson

$12 / 10 / 87$

DISTRIBUTION

PROSECT MANAGER:

DATE SUBMITTED:

Jill Mortimore

$12 / 11 / 87$

CONSTRUCTON

ENGNEER:

Steve Laman

DA TE. SUBMITIED:

$12 / 11 / 87$ 


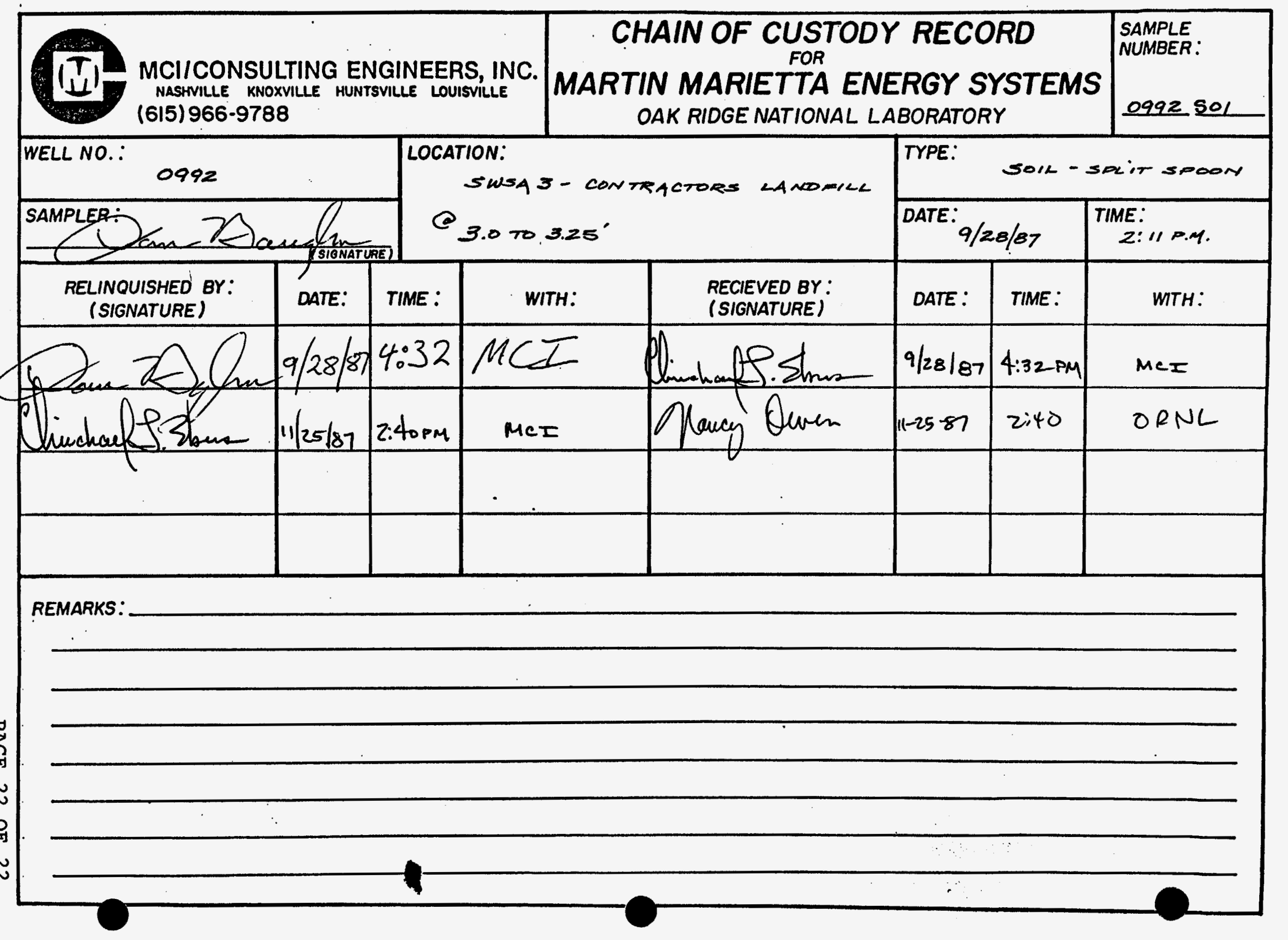




\subsection{General Information}

\subsection{Nell Location}

Monitoring well number 992 is located in WAG 3 . It is located on the north side of the contractors landfill. The location is shown on ORNL drawing number C3E20004 A075. Survey coordinates for this well are N 21,737.0370, E 25,069.6931 (X-10 grid) or latitude $35^{\circ}-55^{\prime}-00.59^{\prime \prime}$ and longitude $84^{\circ}-19^{\prime}-59.22^{\prime \prime}$. Coordinate data were provided by Martin Marietta Energy systems. The method used for conversion from X-10 grid to Tennessee-Lambert state Plane Coordinates came from the publication "Tennessee Valley Authority Data Services Branch and Mapping Services Branch, Oak Ridge, Tennessee, DOE Plant Control, November 6, 1985, Field Book: Ess-3115, pp. 1-20." The latitude and longitude were calculated by Adams Craft Herz Walker Engineering, Inc., using methods from the U.S. Coast and Geodetic survey Publication 62-4, "State Plane coordinates by Automatic Data Processing."

\subsection{Drilling Information}

Well number 992 was drilled by A. I. Clark Drilling Services, Inc. A schramm Rotadrill rig was used to drill this boring for monitor well installation under operation of Rick Pickel with the assistance of Leo Johnson. Drilling commenced on 9-28-87 and was finished on 10-8-87. Paragraph 2.4.1 includes a detailed discussion of the well installation and a well schematic is included on the well installation/ completion form. A synopsis of the drilling activity 
follows. This information was typed directly from field notes and was edited only when necessary for clarification.

9-28-87 The Schramm Rotadrill was steam cleaned and mobilized to the staked location. The boring was split spooned from 0.0 feet to 11.0 feet and the boring was augered from 0.0 feet to 21.0 feet with 6 -inch augers.

9-29-87 The boring was deepened with 6-inch augers from 21 feet to 53.5 feet.

9-30-87 Bailed boring. Dropped auger bit in hole, tried to fish out auger bit.

10-1-87 Bailing hole, dropped bailer, tried to fish out bailer.

10-2-87-10-5-87 Fishing for bailer.

10-6-87 Retrieved bailer, fishing for auger bit.

10-7-87 Bailing well, placed bentonite above lost bit.

10-8-87 Set 2-inch stainless steel screen and casing, sand pack and bentonite.

This well was logged by ERC Environmental and Energy Services Co., Inc., hydrogeologists Dan C. Baughn, Michael L. Ebers and John w. Anderson. All well construction materials and supplies were from Martin Marietta Energy Systems approved batches. The batch origin of individual items is shown on the included Monitoring Well Materials Certification form. 
ERC / EDGE

Environmental

and Energy

Services Co.

\subsection{Technical Information}

\subsection{Decontamination Procedures}

The drilling rig, down hole tools, surface casing, stainless steel screen, stainless steel casing, centralizers, and stainless steel silt trap underwent the cleaning decontamination procedures outlined in the drilling specifications (Release specific Technical Directions for Regulatory Compliance Monitoring Wells Phase 1, Oak Ridge National Laboratory, Oak Ridge, w.0. K-4147, April 1987, pgs. 2-4). A checklist of the cleaned materials is included with this data package.

\subsection{6eology}

WAG 3 is located in Melton Valley which is in the Valley and Ridge Physiographic Province of East Tennessee. WAG 3 is underlain by limestone, siltstone and shale of the Middle Ordovician Chickamauga Group. The Chickamauga Group consists of eight units, designated by letters "A" to "H" (Stockdale, 1951). WAG 3 is underlain by units E, F, G and H. These units consist of thin bedded nodular limestone with clay and shale partings. A portion of unit $H$ and unit F consists of calcareous siltstone alternating with beds of olive gray to maroon shale. Strike and dip varies from $\mathrm{N} 45^{\circ} \mathrm{E}$ to $\mathrm{N} 55^{\circ} \mathrm{E}$ and $25^{\circ}$ to $35^{\circ}$ southeast, respectively. 


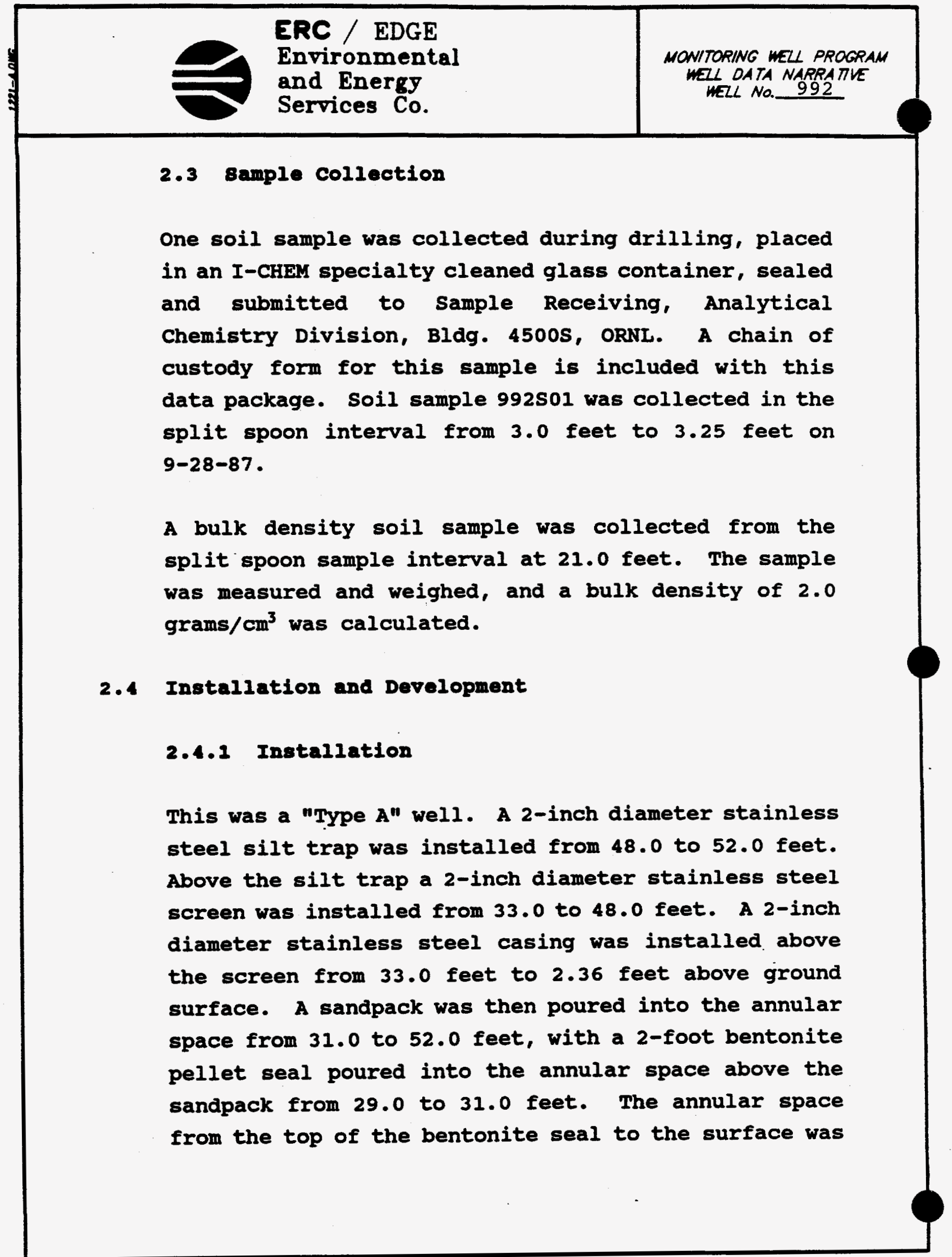


tremie grouted with a cement/bentonite slurry. A detailed schematic of the well is included on the well installation/completion form.

\subsubsection{Well Development}

Well number 992 was developed to remove drill cuttings, silt, and other fines. The monitoring well was developed using a Geoguard pump with an air compressor. All pumps were cleaned prior to use according to specified cleaning procedures (see Paragraph 2.1). The well was developed until a measured total of 320 gallons of water had been evacuated and the clarity of the discharge water was approved by the company representative. The final turbidity value measured at completion was $>100 \mathrm{NTU}$ 's. A development form showing the exact method of development and other pertinent data is appended.

\subsubsection{Installation of Dedicated Monitoring Well Punp}

After the well was developed, a Geoguard Model No. 5614 dedicated monitoring well pump was installed on 4-23-90 at a depth of 44.9 feet below ground surface. These pumps are decontaminated at American Sigma and are sent prepackaged. A copy of the pump certification is kept on file at ORNL.

\subsection{Hydraulic Conductivity Testing}

well number 992 was not tested for hydraulic conductivity. The water level in the well was too low 


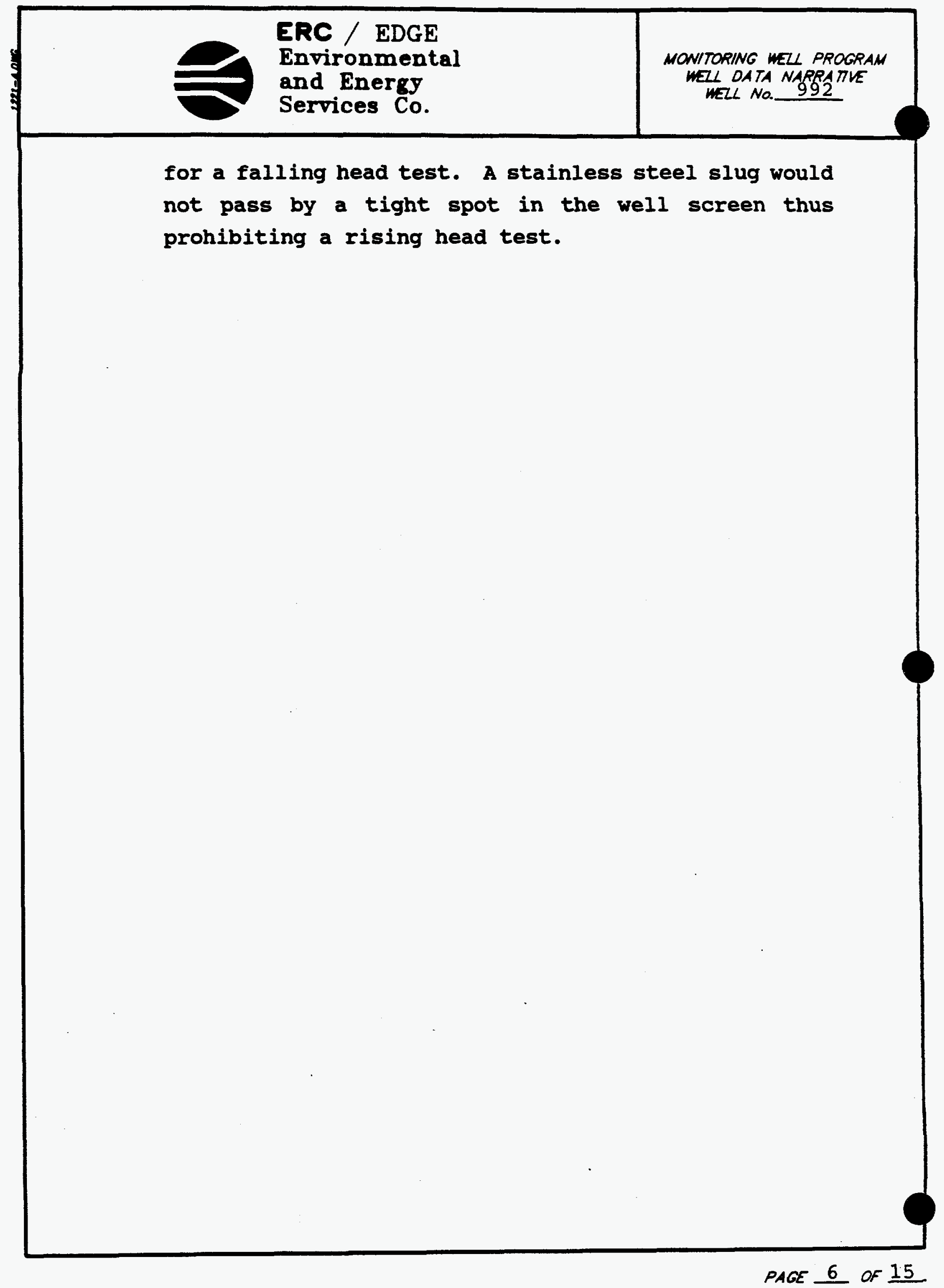


ERC / EDGE

Environmental

and Energy

WELL NO. 992

\section{PRE-DRILLING CHECKLIST FOR MONITORING WELLS}

PRE-ORILLING TASKS

1. EXCAVATION PERWIT OBTAINED.

2. ALL EQUIPMENT HAS BEEN CLEANED BEFORE DRILLNG.

3a. SCREEN AND CASINGS HAVE BEEN WASHED, STEAMED, RINSED WIH DE-IONIZED OR DISTLLED WATER. RINSED WIH ISOPROPY ALCOHOL WRAPPED WTH PROTECTVE COVERING AND STORED OFF THE GROUND.

36. PRE-PACKAGED SCREENS, CASINGS ANO CENTRALIERS WERE USEO.

4. WORK AREA FOR SAMPLE EXAMINA HOW COVERED WTH CLEAN POL TETHYENE.

5. CLEAN KNIVE, QLOVES, SAMPLE JARS ANO LABELS ON-HAND.

6. POLYTHYENE COVER IN PLACE OVER HOLE. ADOITONAL NOTES/OBSERVATONS.

$\frac{\text { COMPLIANCE }}{\text { DATT}} \frac{\text { IN/TALS }}{\text { M/28/87 }}$
$\frac{9 / 28 / 87}{N / A}$ MLE

10/08/87 Me $9 / 28 / 87$ Whe

$9 / 28 / 87 \quad$ CLE

$9 / 28 / 87$ MLE

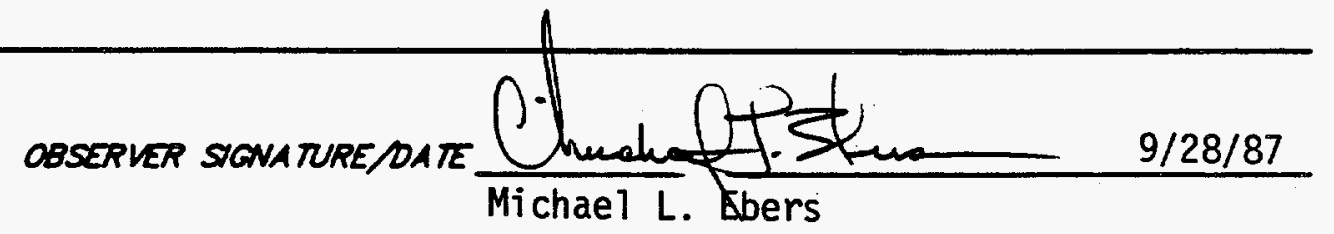




\begin{tabular}{|c|c|c|c|c|c|}
\hline & $\infty$ & $\begin{array}{l}\text { EDGE } \\
\text { iment } \\
\text { ergJ } \\
\text { S Co. }\end{array}$ & & & WELL NO. 992 \\
\hline \multicolumn{6}{|c|}{$\frac{\text { DECONTAMINA TION CHECKLIST }}{\text { DRILLING EQUIPMENT }}$} \\
\hline EQUIPMENT & SCRAPE & $\begin{array}{l}\text { STEAM } \\
\text { CLEAN }\end{array}$ & $\begin{array}{l}\text { STEAM } \\
\text { RINSE }\end{array}$ & $\begin{array}{c}\text { ISOPROPY } \\
\text { ALCOHOL } \\
\text { RINSE }\end{array}$ & $\begin{array}{c}\text { DEIONIZED } \\
\text { WATER } \\
\text { RINSE } \\
\end{array}$ \\
\hline$R / G$ & $x$ & $x$ & $x$ & $N / A$ & $N / A$ \\
\hline AUGERS & $x$ & $x$ & $x$ & $x$ & $x$ \\
\hline BITS & $x$ & $x$ & $x$ & $x$ & $x$ \\
\hline RODS & $x$ & $x$ & $x$ & $x$ & $x$ \\
\hline SAMPLERS & $x$ & $x$ & $x$ & $x$ & $x$ \\
\hline PIPES & $x$ & $x$ & $x$ & $x$ & $x$ \\
\hline WORK TOOLS & $x$ & $x$ & $x$ & $x$ & $x$ \\
\hline AUGER PINS & $x$ & $x$ & $x$ & $x$ & $x$ \\
\hline & & & & & \\
\hline & & & & & \\
\hline & & & & & \\
\hline & & & & & \\
\hline
\end{tabular}

OBSERVER SIGNATURE/DATE $\frac{\text { Michaet L. Euduers }}{\text { Ebers }}$ 
ORNL MONITORING WELL LOG

LOCA MON: WAG-3 at N. End of Contractors

DRILLER: Rick Pickle

HELPER: LeO JohnSOn

ORIL: Schramm

\section{PAGE 1 or 2}

DAT: START: $\frac{9 / 28 / 87}{10 / 08 / 87}$

FINISH: 10/08/87 Dañe c. Baughn LOGGE Br: Michael i Ehers HEALTH PHYSICST: PaUT Eldridge

TPE ORILUNG: Split Spoon/Auger

No. SAMPLES TAKEN: One

LUBRICANT MPE: Molvkote 1000 MPE: Soil

CONTANMENT TPE: Auger Pan and Plastic

THICKNESS OF SOL (REFUSAL DEPTH): 42.0

DRUUNG FUUD SAMPLES.

OEPTH ORILED IN ROCK: 11.5

MPE: N/A DATE:

TOTAL OEPTH OF MEL: $\quad 53.5$

\begin{tabular}{|c|c|c|c|c|}
\hline \multicolumn{2}{|c|}{ 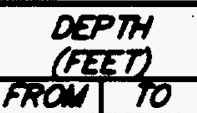 } & $\begin{array}{l}\text { SUMPUE } \\
\text { (NUMGER } \\
\text { INTERVAL) }\end{array}$ & $\begin{array}{c}\text { PERCENT } \\
\text { RECOVERY } \\
\text { (SPUT SPOONS) }\end{array}$ & sou beprock oEscription \\
\hline 0.0 & 2.25 & & $100 \%$ & $\mathrm{Cl}$ ay - red to reddish brown with fine root \\
\hline & & & & channels and roots, isolated nodules of dark \\
\hline & & & & friable material (possibly an Mn/Fe oxide). \\
\hline & & & & Slightly silty, negligible moisture. \\
\hline \multirow[t]{7}{*}{2.25} & 4.35 & 0992501 & & Clay - reddish brown with angular pieces of \\
\hline & & $03.0-3.25^{\prime}$ & & very fine sandstone - friable with cement \\
\hline & & & & weathered out light tan, predominant with \\
\hline & & & & some very light red. Nodules at dark \\
\hline & & & & "oxidized" material still apparent but \\
\hline & & & & gradually thinning out by $3^{\prime}$ interval. \\
\hline & & & & Slightly silty, negligible moisture. \\
\hline \multirow[t]{7}{*}{4.35} & 6.55 & & $100 \%$ & Clay - red, mottled light brown with less \\
\hline & & & & sandstone and only light tan variety (no \\
\hline & & & & red ss.). Dark oxized material rare, \\
\hline & & & & slightly silty, negligible moisture. \\
\hline & & & & Difficulty obtaining sample - raised rig \\
\hline & & & & while driving spoons. However, no rock \\
\hline & & & & debris in base of drive shown. \\
\hline \multirow[t]{3}{*}{6.55} & 8.80 & & $100 \%$ & Clay red mottled light brown as above with the \\
\hline & & & & exception of the reappearance of the dark \\
\hline & & & & "oxidized" nodules at 8.15 '. Decrease in \\
\hline
\end{tabular}




\begin{tabular}{|c|c|c|c|c|}
\hline \multicolumn{4}{|c|}{ ORNL MONITORING WELL LOG } & PACE 2 of 2 \\
\hline \multicolumn{2}{|c|}{ 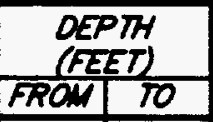 } & $\begin{array}{l}\text { SAMPLE } \\
\text { (NUWBER } \\
\text { INTERVAL) }\end{array}$ & $\begin{array}{c}\text { PERCENT } \\
\text { RECOVERY } \\
\text { (SPLIT SPOONS) }\end{array}$ & SOLLBEDROCK DESCRIPTION \\
\hline \multirow[t]{2}{*}{6.55} & 8.80 & & & (continued from page 1) silt fraction, \\
\hline & & & & negligible moisture. \\
\hline \multirow[t]{5}{*}{8.8} & 11.0 & & & Clay, red mottled dark red to light brown, \\
\hline & & & & with dark "oxidized" nodules and very fine \\
\hline & & & & sandstone occuring with angular pebble sized \\
\hline & & & & fragments throughout. Refusal, but in clay - \\
\hline & & & & very stiff with negligible moisture. \\
\hline \multirow[t]{4}{*}{11.0} & 21.0 & & & Very stiff augering, returns are black frag- \\
\hline & & & & ments of mottled red and brown clay which \\
\hline & & & & appears in contorted layers. - possibly reflect \\
\hline & & & & bedding features? \\
\hline \multirow[t]{5}{*}{21.02} & 26.0 & & & Clay - red and mottled light brown as above \\
\hline & & & & with slight increase in moisture. \\
\hline & & & & Bulk Density $=2.0$ arams $/ \mathrm{cm}^{3}$ \\
\hline & & & & \\
\hline & & & & \\
\hline 26.02 & 26.5 & & & Chert? Cobble. \\
\hline \multirow[t]{2}{*}{26.5} & 42.0 & & & Clay, light brown, plastic, damp to almost \\
\hline & & & & moist, fairly soft. \\
\hline 42.0 & 42.5 & & & Limestone, hard. \\
\hline 42.5 & 43.0 & & & Clay, soft, cavity fill? \\
\hline 43.0 & 46.5 & & & Limestone, fairly hard. \\
\hline 46.5 & 52.5 & & & Cavity, filled with mud and water. \\
\hline \multirow{9}{*}{52.5} & 53.5 & & & Limestone. \\
\hline & 53.5 & & & Total Depth \\
\hline & & & & Note: Lost auger bit in bottom of boring, \\
\hline & & & & could not recover - put a 2" layer of bento- \\
\hline & & & & nite pellets in bottom of boring in an effort \\
\hline & & & & to seal it off. Abundant water while \\
\hline & & & & bailing. \\
\hline & & & & \\
\hline & & & & \\
\hline & & & & \\
\hline
\end{tabular}




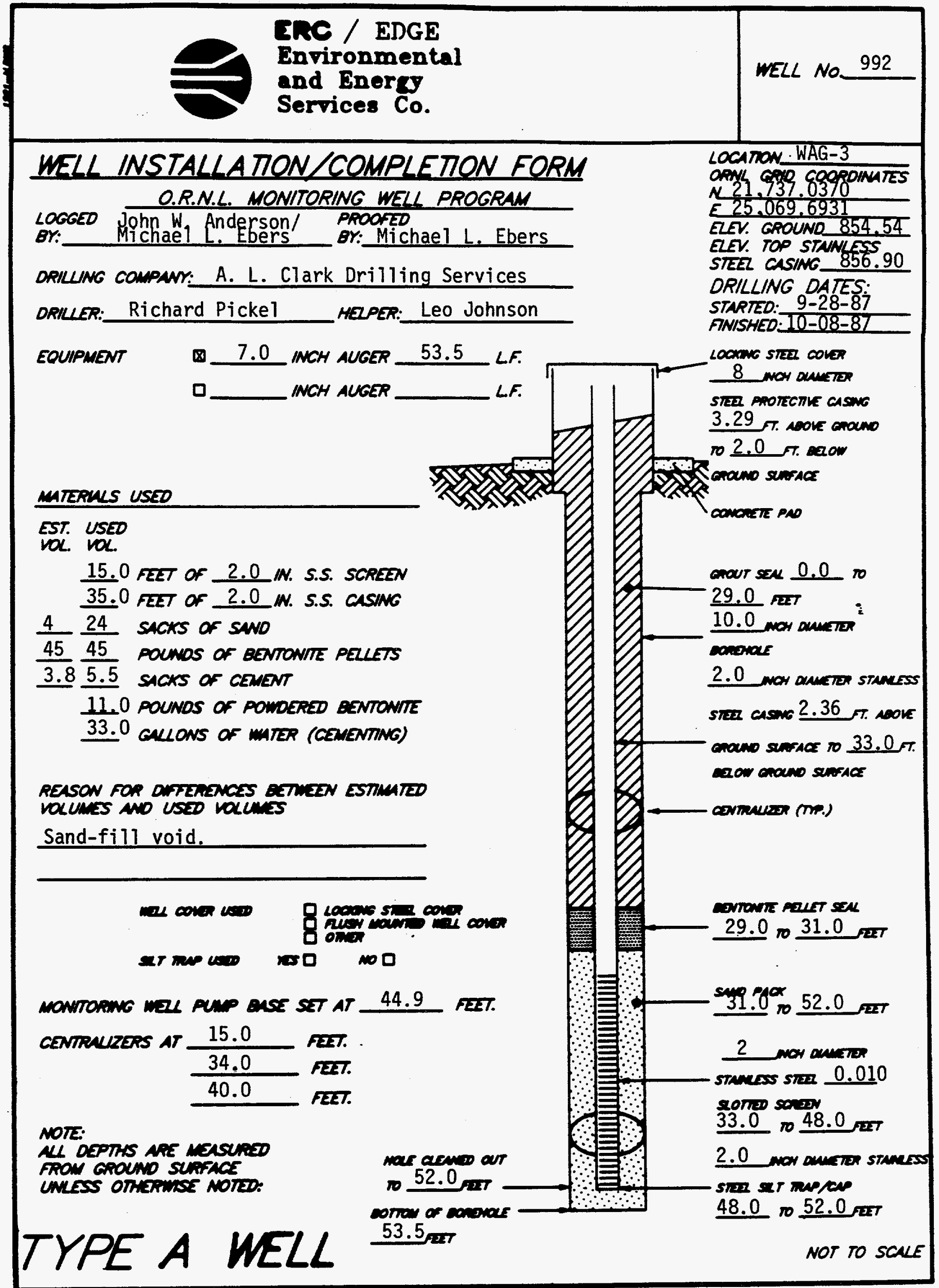

PACE 11 of 15. 
ERC / EDGE

Environmental

WELL No. 992

and Energy

Services Co.

DATE: $9 / 28 / 87$

\section{MONITORING WELL MATERIALS CERTIICATION}

ITEM/MA TERIAL

\begin{tabular}{|c|c|c|}
\hline & DAIE USED & BATCH NUMBER \\
\hline & $10 / 08 / 87$ & 2 \\
\hline & $10 / 08 / 87$ & 2 \\
\hline$\left(\begin{array}{c}Y E S \\
\text { NO }\end{array}\right.$ & $10 / 08 / 87$ & 5 \\
\hline $\begin{array}{l}\left(\begin{array}{l}Y E S \\
(N O\end{array}\right) \\
\end{array}$ & $10 / 08 / 87$ & 5 \\
\hline 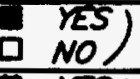 & $10 / 08 / 87$ & 5 \\
\hline $\begin{array}{l}\text { YES } \\
\text { NOS } \\
\end{array}$ & $10 / 08 / 87$ & 5 \\
\hline$\left(\begin{array}{l}\text { TES } \\
\text { nO }\end{array}\right.$ & $4 / 23 / 90$ & 5 \\
\hline & $10 / 09 / 87$ & 11 \\
\hline & & \\
\hline & $10 / 87$ & 2 \\
\hline
\end{tabular}

COMMENTS:

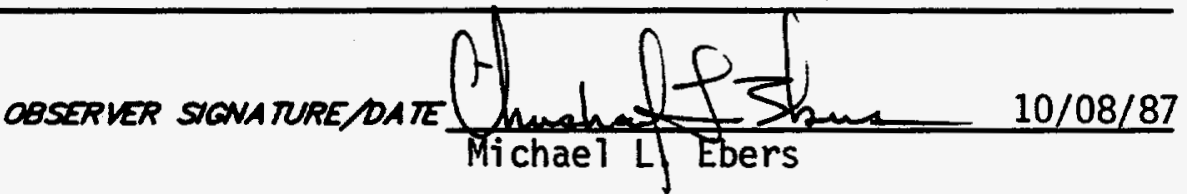

PAGE 12 of 15. 
ERC / EDGE

Environmental

and Energy

WELL No. 992

Services Co.

\section{POST-WELL COMPLETION CHECKLIST}

\section{POST-WELL COMPLETION TASKS}

\section{COMPLIANCE \\ DA.TE INITIALS}

1. WO SCRAPED FRON AUGERS SMMPLERS ANO ALL

$\underline{10 / 08 / 87}$

ME OTHER EQUIPIENT.

$10 / 08 / 87$

WNE

2. ALL WUD FRON RIG ANO EQUIPNENT SCRAPWOS INO CUTTINOS DSPOSED OF W ACCOPDANCE WTH THE SPECARCA IION PROWOED.

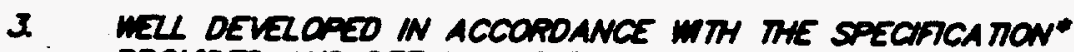

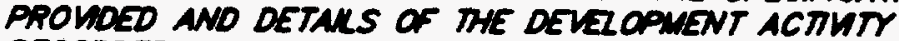
RECOROED.

4. DAULNG STE PROPERL Y CLANED UP AFTER I completion of "nEL INSTALLATION.

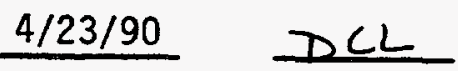

NE

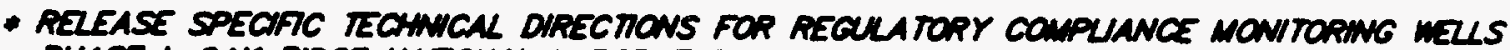
PHASE b OAK RIOCE NATIONAL LABORA TOPY, OAK ROCE, WO K-4147, APRK 1987.

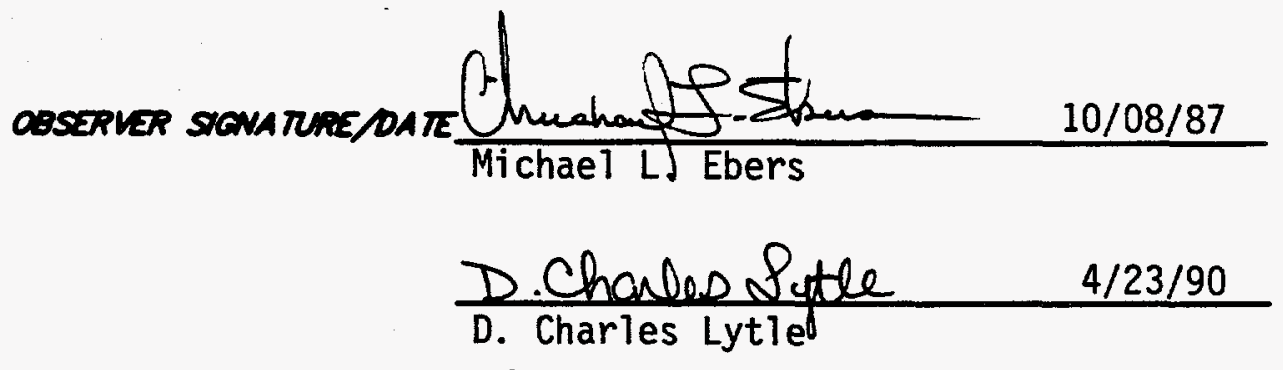




\section{MONITORING WELL \\ DEVELOPMENT FORM}

OEVELOPMENT DETAILS

METHOD OF

DEVELOPMENT: Surging and Pumping

DEVELOPMENT

BEGAN DATE: $\quad 4 / 03 / 90$

TME:

DEVELOPMENT

ENDING DATE:

$4 / 23 / 90$

OEVELOPMENT

OBSERVED BY:

D. Charles Lytle

ONE WELL VOLUME.

10.4 GALLONS

TOTAL GALLONS PUMPED: 320 TOTAL WELL VOLUMES PUMPED:- 30.8

INITAL PH: 7.4 FNAL PH: 7.5

INITAL CONDUCTUTY (K S/cm): 923

OESCRIPTION OF INITAL TURBIDIT:

FNAL CONDUCHUTY $(\mu \mathrm{s} / \mathrm{cm}):-951$

DESCRIPTION OF FINAL TURBIOITY:_ Muddy

FNAL MEASURED TURBIDITY: Greater than 100 NTU's

WELL APPROVED BY: R. C. Williams MMES

ODOR

OF MATER. None

WA TER

DISCHARGED

GROUND SURFACE

TO:

口 STORM SEWERS

口 TANK TRUCK

I STORAGE TANKS

口 OTHER

INITAL PRE-DEVELOPMENT

WA TER DEPTH:

36.0 feet from ground surface.

DEVELOPMENT OBSERVATIONS

Well has bend in stainless steel casing, can only measure to 50.4 feet.

Had to develop with work over rig.

OBSERVER SIGNATURE DATE D.Chavesofute

$4 / 23 / 90$

D. Charles Lytie 


\section{MONITORING WELL DEVELOPMENT PROGRESS}

\begin{tabular}{|c|c|c|c|c|c|c|c|c|c|}
\hline \multicolumn{10}{|c|}{ ONE WELL VOLUME $=10.4$ GALLONS } \\
\hline$D A T E$ & TME & $\begin{array}{l}\text { Genows } \\
\text { Pumped }\end{array}$ & 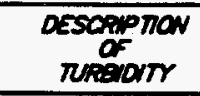 & 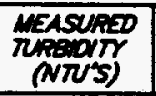 & $\rho H$ & $\begin{array}{l}\text { conouc- } \\
m M n r \\
(\mu S /(m)\end{array}$ & 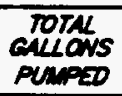 & 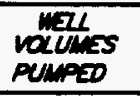 & COMMENTS \\
\hline $4-17-90$ & 1430 & 95 & Muddy & -- & 7.4 & 923 & 95 & 9.1 & \\
\hline $4-23-90$ & 1400 & 225 & Muddy & * & 7.5 & 951 & 320 & 30.8 & \\
\hline & & & & & & & & & \\
\hline & & & & & & & & & \\
\hline & & & & & & & & & \\
\hline & & & & & & & & & \\
\hline & & & & & & & & & \\
\hline & & & & & & & & & \\
\hline & & & & & & & & & \\
\hline & & & & & & & & & \\
\hline & & & & & & & & & \\
\hline & & & & & & & & & \\
\hline & & & & & & & & & \\
\hline & & & & & & & & & \\
\hline & & & & & & & & & \\
\hline & & & & & & & & & \\
\hline & & & & & & & & & \\
\hline $\begin{array}{l}\text { RESULTS } \\
\text { OF DEVEL }\end{array}$ & $\begin{array}{l}\text { TEND } \\
\text { OMENT }\end{array}$ & & Muddy & * & 7.5 & 951 & 320 & 30.8 & \\
\hline
\end{tabular}

COMMENTS We11 was crooked. Had to develop with work over rig. Poor producer, dried quickly, remained muddy and would not clear. Had to pass on account of 30.8 well volumes: and moved to another hole. * Greater than 100 NTU's. 
ERC / EDGE

Environmental

and Energy

Services Co.

\subsection{General Information}

\subsection{Well Location}

Monitoring well number 993 is located in WAG 3 . It is located in the northeastern corner of the contractors landfill. The location is shown on ORNL drawing number C3E20004 A075. Survey coordinates for this well are $N 21,884.3521, E 25,619.0831$ (X-10 grid) or latitude $35^{\circ}-55^{\prime}-04.82^{\prime \prime}$ and longitude $84^{\circ}-19^{\prime}-54.66^{\prime \prime}$. Coordinate data were provided by Martin Marietta Energy systems. The method used for conversion from X-10 grid to Tennessee-Lambert state Plane Coordinates came from the publication "Tennessee Valley Authority Data Services Branch and Mapping Services Branch, Oak Ridge, Tennessee, DOE Plant Control, November 6, 1985, Field Book: Ess-3115, pp. 1-20." The latitude and longitude were calculated by Adams Craft Herz Walker Engineering, Inc., using methods from the U.S. Coast and Geodetic survey Publication 62-4, "State Plane Coordinates by Automatic Data Processing."

\subsection{Drilling Information}

Well number 993 was drilled by A. L. Clark Drilling Services, Inc. A Gus Pech rig was used to drill this boring for monitor well installation under operation of A. I. Clark, III with the assistance of Leo Johnson. Drilling commenced on 12-2-87 and was finished on 12-9-87. Paragraph 2.4.1 includes a detailed discussion of the well installation and a well schematic is included on the well installation/ completion form. A synopsis of the drilling activity 
follows. This information was typed directly from field notes and was edited only when necessary for clarification.

12-2-87 The rig was mobilized to the staked location and set up.

12-3-87 The boring was split spooned from 0.0 feet to 10.0 feet and augered from 0.0 feet to 10.8 feet with 14-inch augers.

12-4-87 A 12-foot section of 10-inch surface casing was steam cleaned, set in the boring and grouted.

12-7-87 The boring was deepened with an 8-inch hammer bit.

12-8-87 The boring was set with 4-inch stainless steel casing and screen. A sandpack and bentonite seal were installed.

12-9-87 The annular space was grouted.

This well was logged by ERC Environmental and Energy Services Co., Inc., hydrogeologist Bryn D. Howze. All well construction materials and supplies were from Martin Marietta Energy Systems approved batches. The batch origin of individual items is shown on the included Monitoring Well Materials Certification form.

\subsection{Technical Information}

\subsection{Decontamination Procedures}

The drilling rig, down hole tools, surface casing, stainless steel screen, stainless steel casing, centralizers, and stainless steel silt trap underwent 
the cleaning decontamination procedures outlined in the drilling specifications (Release specific Technical Directions for Regulatory Compliance Monitoring Wells Phase 1, Oak Ridge National Laboratory, Oak Ridge, w.0. K-4147, April 1987, pgs. 2-4). A checklist of the cleaned materials is included with this data package.

\subsection{Goology}

WAG 3 is located in Melton Valley which is in the Valley and Ridge Physiographic Province of East Tennessee. WAG 3 is underlain by limestone, siltstone and shale of the Middle Ordovician Chickamauga Group. The Chickamauga Group consists of eight units, designated by letters "A" to "H" (Stockdale, 1951). WAG 3 is underlain by units $E, F, G$ and $H$. These units consist of thin bedded nodular limestone with clay and shale partings. A portion of unit $H$ and unit $F$ consists of calcareous siltstone alternating with beds of olive gray to maroon shale. Strike and dip varies from $N 45^{\circ} \mathrm{E}$ to $\mathrm{N} 55^{\circ} \mathrm{E}$ and $25^{\circ}$ to $35^{\circ}$ southeast, respectively.

\section{3 sample collection}

Two soil samples were collected during drilling, placed in I-CHEM specialty cleaned glass containers, sealed and submitted to Sample Receiving, Analytical Chemistry Division, Bldg. 4500S, ORNL. Chain of custody forms for these samples are included with this data package. Soil sample 99351 was collected in the augered/split spoon interval from 0.5 feet to 0.7 feet 
on 12-3-87 and soil sample 99352 was collected in the split spoon interval from 9.6 feet to 9.8 feet on 12-3-87.

A drill water sample was collected from the water pump on the drill rig on 12-7-87. Analytical results for the three samples described above can be obtained from the Remedial Action Program data base at ORNL.

\subsection{Installation and Development}

\section{4 .1 Installation}

This was a "Type B" well. A 14-inch diameter boring was augered from ground surface to bedrock (10.8 feet). A 10-inch diameter string of decontaminated steel surface casing was installed and tremie grouted in place. The surface casing minimizes potential cross contamination between the regolith and bedrock water bearing zones. The air rotary method was then used to drill an 8-inch diameter boring to a total depth of 45.0 feet. A 4-inch diameter stainless steel silt trap was installed from 44.7 to 45.0 feet. Above the silt trap, a 4-inch diameter stainless steel screen was installed from 23.9 feet to 44.7 feet. A 4-inch diameter stainless steel casing was installed from the top of the screen at 23.9 feet and extending 1.75 feet above ground surface. A sandpack was then poured into the annular space from 21.9 to 45.0 feet, with a 2.4-foot bentonite seal poured into the annular space above the sandpack from 19.5 to 21.9 feet. The annular space from the top of the bentonite seal to the surface was tremie grouted with a cement/bentonite 
slurry. A detailed schematic of the well is included on the well installation/completion form.

\subsubsection{We11 Development}

Well number 993 was developed to remove drill cuttings, silt, and other fines. The monitoring well was developed using a Geoguard pump with an air compressor. All pumps were cleaned prior to use according to specified cleaning procedures (see Paragraph 2.1). The well was developed until a measured total of 564 gallons of water had been evacuated and the clarity of the discharge water was approved by the company representative. The final turbidity value measured at completion was $2.0 \mathrm{NTU}$ 's. A development form showing the exact method of development and other pertinent data is appended.

\subsubsection{Installation of Dedicated Monitoring well Pump}

After the well was developed, a Geoguard Model No. 5614 dedicated monitoring well pump was installed on 5-7-90 at a depth of 42.6 feet below ground surface. These pumps are decontaminated at American sigma and are sent prepackaged. A copy of the pump certification is kept on file at ORNL.

\subsection{Hydraulic Conductivity Testing}

Well number 993 was tested for the determination of hydraulic conductivity of the aquifer in the vicinity of the well screen. This was accomplished by 
instantaneously adding a known quantity of water to the monitoring well and measuring the recovery of the water level over time. The changing water levels were measured using a Druck 15 psig pressure transducer and an omnidata Datapod II data recorder. The hydraulic conductivity value of $3.67 \times 10^{-4} \mathrm{~cm} / \mathrm{second}$ (shown as permeability on the hydraulic conductivity calculations printout attached) was calculated using the Bouwer and Rice method. A computer printout of the hydraulic conductivity calculations is included in this data package. 
ERC / EDGE

Environmental

and Energy

WELL NO. 993

Services Co.

\section{PRE-DRILLING CHECKLIST FOR MONITORING WELLS}

\section{PRE-DRILLING TASKS}

1. EXCAVATION PERMIT OBTAINED.

2. ALL EQUIPMENT HAS BEEN CLEANED BEFORE DRILUNG.

30. SCREEN AND CASINGS HAVE BEEN WASHED, STEAMED, RINSED WIH DE-IONIZED OR DISTLLED WATER, RINSED WTH ISOPROPV ALCOHOL WRAPPED WTH PROTECTVE COVERING ANO STOREO OFF THE GROUNO.

3b. PRE-PACKAGED SCREENS, CASINGS AND CENTRALUZERS MERE USED.

4. MORK AREA FOP SAMPLE EXAMINATION COVERED WTH CLEAN POL YETHRENE.

5. CLEAN KNIES, GLOVES, SAMPLE JARS AND LABELS ON-HAND.

6. POLYETHYENE COVER IN PLACE OVER HOLE. ADOITONAL NOTES/OBSERVATONS.

\section{6.} s.
COMPLIANCE

DATE INITALS

$12 / 03 / 87$ DDH

$12 / 03 / 87 \quad B D H$

$N / A$

$\underline{12 / 08 / 87}$ BDH

$\underline{12 / 03 / 87}$

12/03/87 BDH

12/03/87 BDH

OBSERVER SIGNATURE DATE $\frac{\text { Brya H. Oforze 12/03/87 }}{\text { Bryn D. Howze }}$ 


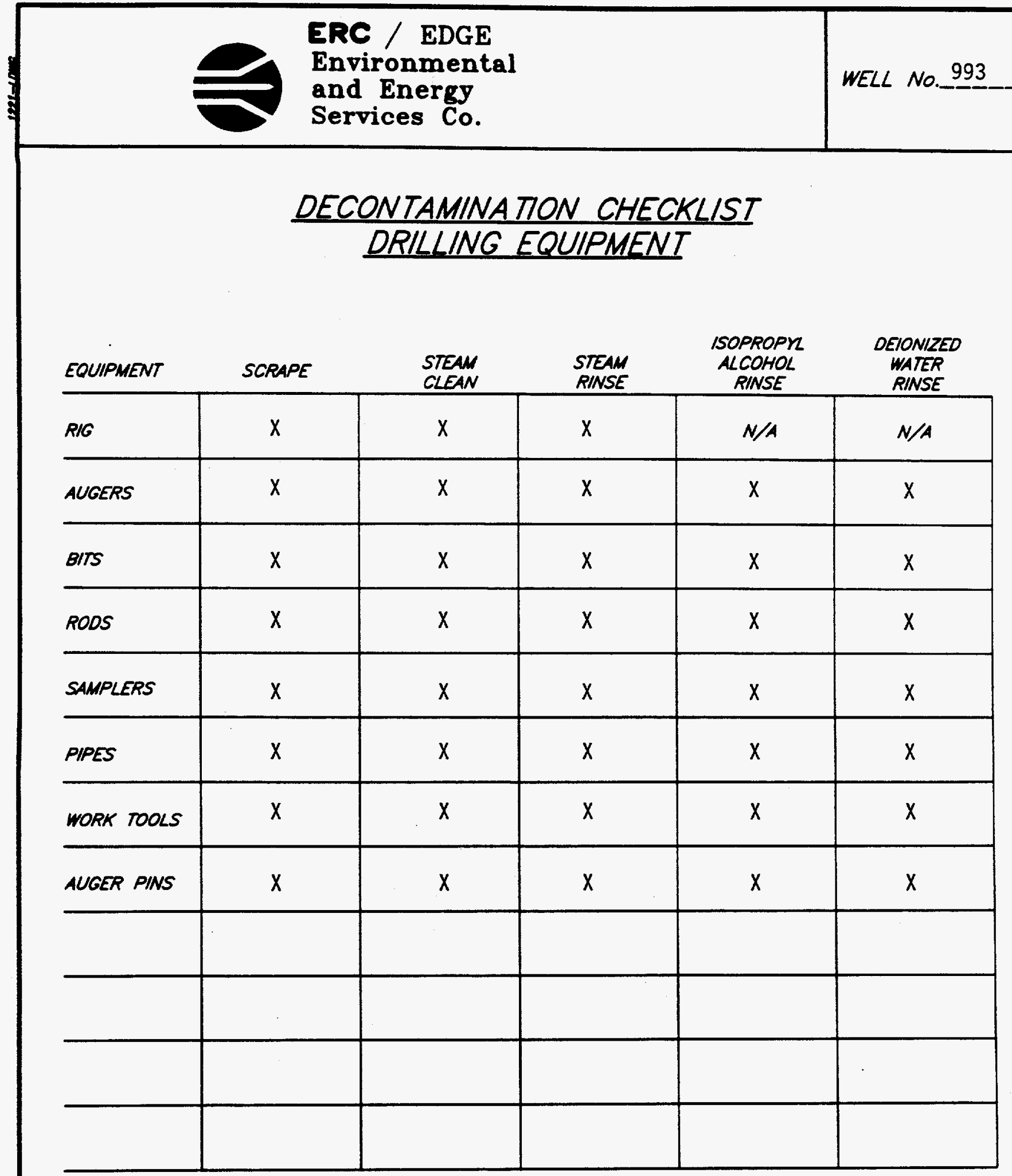

OBSERVER SIGNATURE/DATE $\frac{7 / y y}{\text { Bryn D. Howze }}$ Afouge 12/02/87 
ORNL MONITORING WELL LOG

LOCA MON: SWSA 3

DRILLER: Avery L. Clark II

HELPER: LeO Johnson

DRILL: Gus Pech
PACE 1 of 2

DATE: START: $12 / 03 / 87$

FINISH: $12 / 09 / 87$

LOGGeD Br: Bryn D. Howze

HEALTH AHISICST: Paul Eldridge

MPE ORILLNG: Auger, Air Rotary

LUBRICANT MPE: Green Stuff

No. SAMPLES TAKEN: 3

MPE: 2 Soil/1 Drilling Water

CONTAMNGEN MPE: Plastic, Auger Pan, Containment Box

THICKNESS OF SOL (RERUSAL DEPTH): $10.0^{\prime}$

DEPTH DRILLD IN ROCX: $35.0^{\prime}$

TOTAL OEPTH OF WEL: 45. 4

\begin{tabular}{|c|c|c|c|c|}
\hline \multicolumn{2}{|c|}{$\begin{array}{c}\text { DEPTH } \\
\text { (FEET) } \\
\text { RROM TO }\end{array}$} & $\begin{array}{l}\text { SUMFEE } \\
\text { (NUMESR } \\
\text { NTERVAL) }\end{array}$ & $\begin{array}{c}\text { PERCENT } \\
\text { RECOVERY } \\
\text { (SPUT SPOONS) }\end{array}$ & 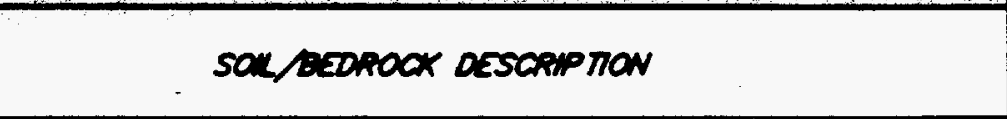 \\
\hline 0.0 & 0.4 & & $100 \%$ & Topsoil, silt, medium to dark brown, with \\
\hline & & & & roots and rock fragments, firm. \\
\hline \multirow[t]{4}{*}{0.4} & 4.6 & $0993 \$ 1$ & $100 \%$ & Silt, slightly sandy, light brown, mottled \\
\hline & & $0.5-0.7^{\prime}$ & & black, orange, yellow, with weathered rock \\
\hline & & & & fragments, very stiff (more clayey in lower \\
\hline & & & & $\left.0.5^{\prime}\right)$ \\
\hline \multirow[t]{6}{*}{4.6} & 5.2 & & $100 \%$ & Weathered limestone and clay, slightly silty, \\
\hline & & & & limestone, light gray (weathered) to greenish \\
\hline & & & & gray (fresh) appears as float in clay that \\
\hline & & & & is slightly silty, medium brown to orange \\
\hline & & & & brown, mottled black, yellow, red, greenish \\
\hline & & & & gray, very stiff. \\
\hline \multirow[t]{3}{*}{5.2} & 6.8 & & $100 \%$ & Clay, slightly silty, medium brown to orange \\
\hline & & & & brown, mottled black, yellow, red, greenish \\
\hline & & & & gray, very stiff. \\
\hline \multirow[t]{3}{*}{6.8} & 10.0 & $0993 \mathrm{~S} 2$ & $100 \%$ & Silt, very clayey, medium brown, mottled orange \\
\hline & & $9.6-9.8^{\prime}$ & & black, yellow, red, weathered limestone at \\
\hline & & & & $10.0^{\prime}$, very stiff to hard. \\
\hline \multirow[t]{3}{*}{10.0} & 10.8 & & & Limestone, light gray, weathered. Auger \\
\hline & & & & refusal at $10.8^{\prime}$. No detailed lithologic \\
\hline & & & & description available from $10.8^{\prime}$ to $45.0^{\prime}$ due \\
\hline
\end{tabular}

DRULNG RUD SAMPLES.

MPE: Water DAT: $12 / 07 / 87$ 


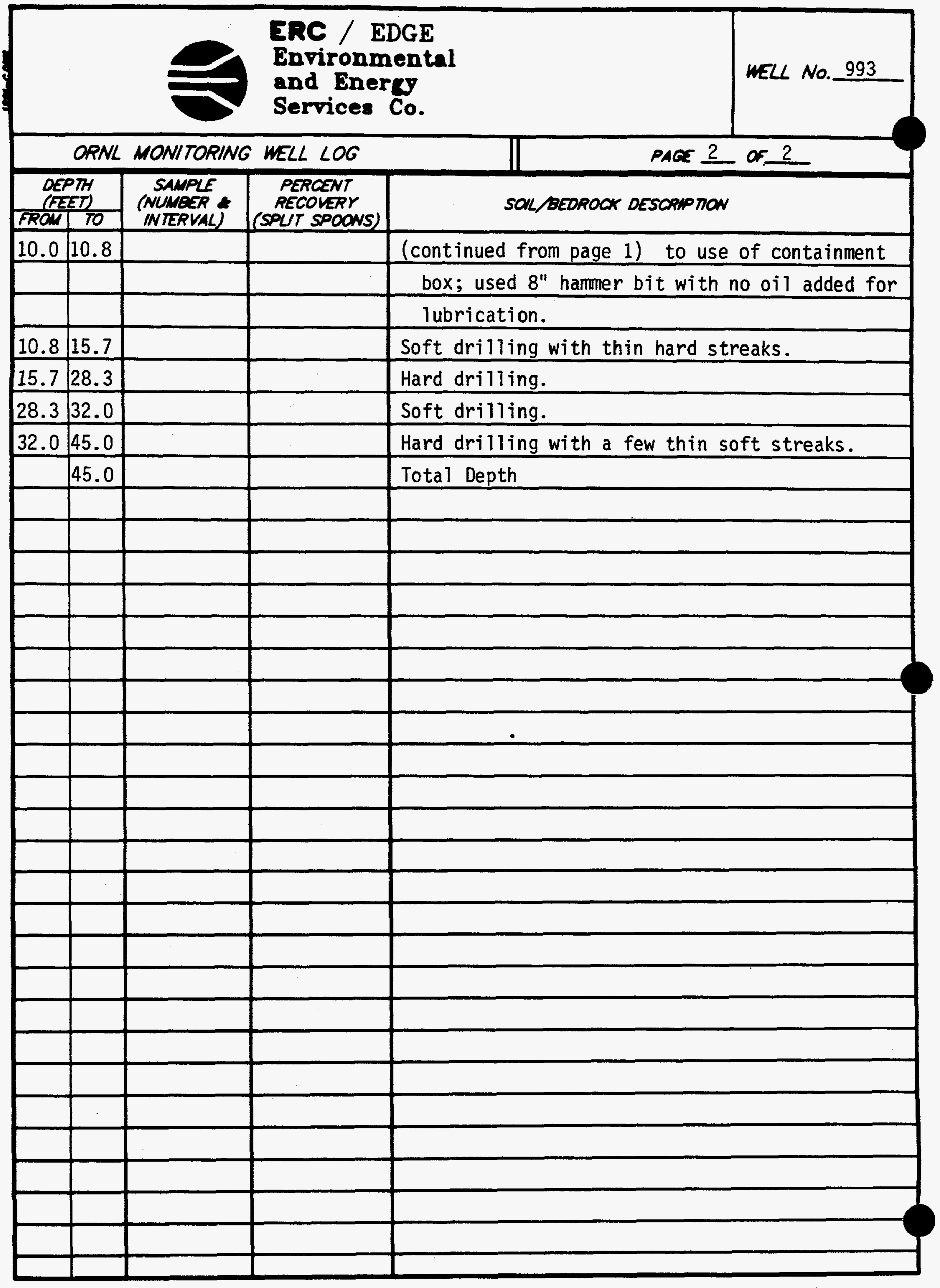

PACE 10 of 21. 


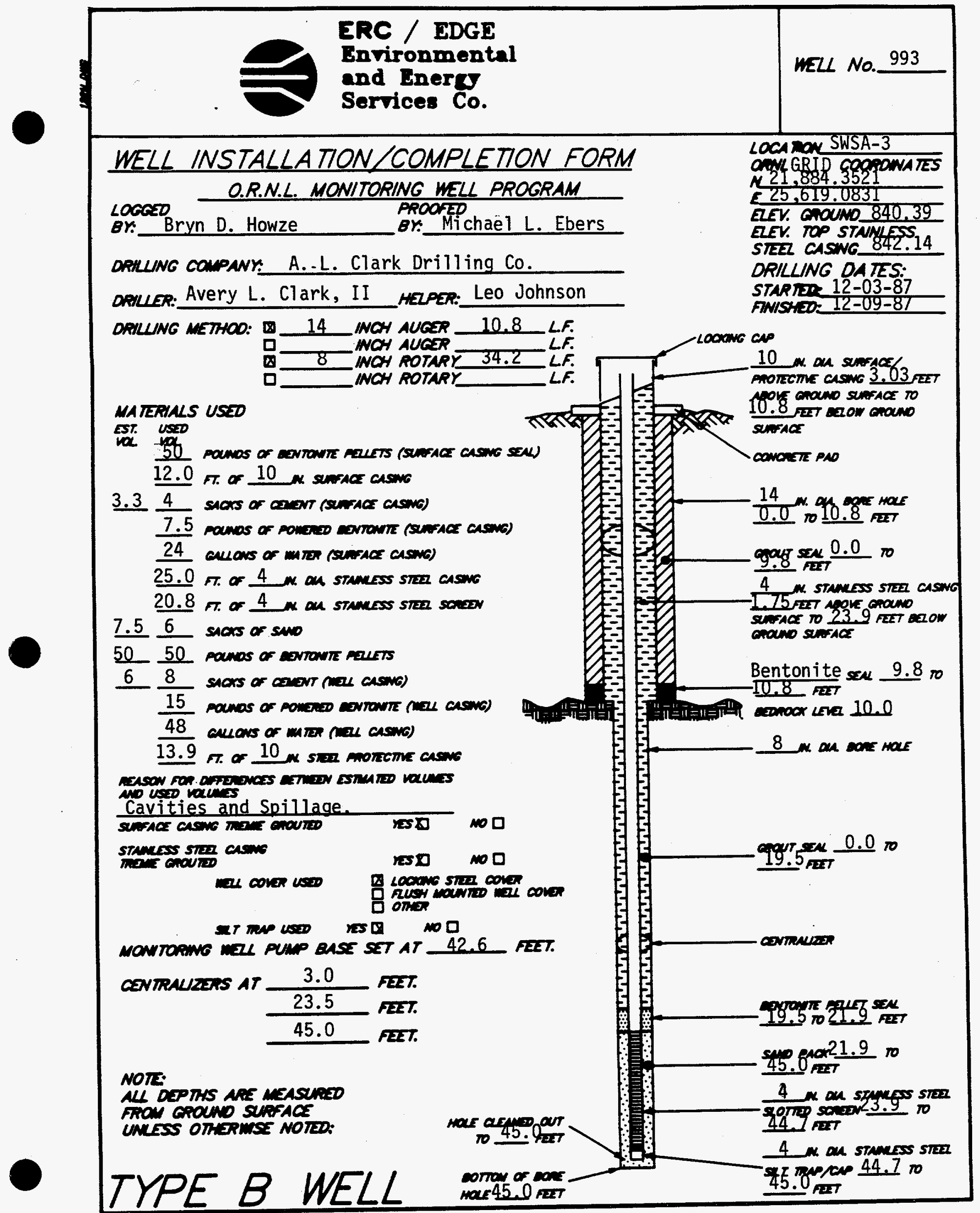


ERC / EDGE

Environmental

WELL NO. 993

and Energy

Services Co.

DATE: $12 / 09 / 87$

\section{MONITORING WELL MATERIALS CERTIFICATION}

ITEM/MATERIAL

DAIE USED BATCH NUMBER

SAND

BENTONITE

STAINLESS STEEL SCREEN

STAINLESS STEEL CASING

STAINLESS STEEL CENTRALIZERS

STAINLESS STEEL CAPS

MONITORING WELL PUMP

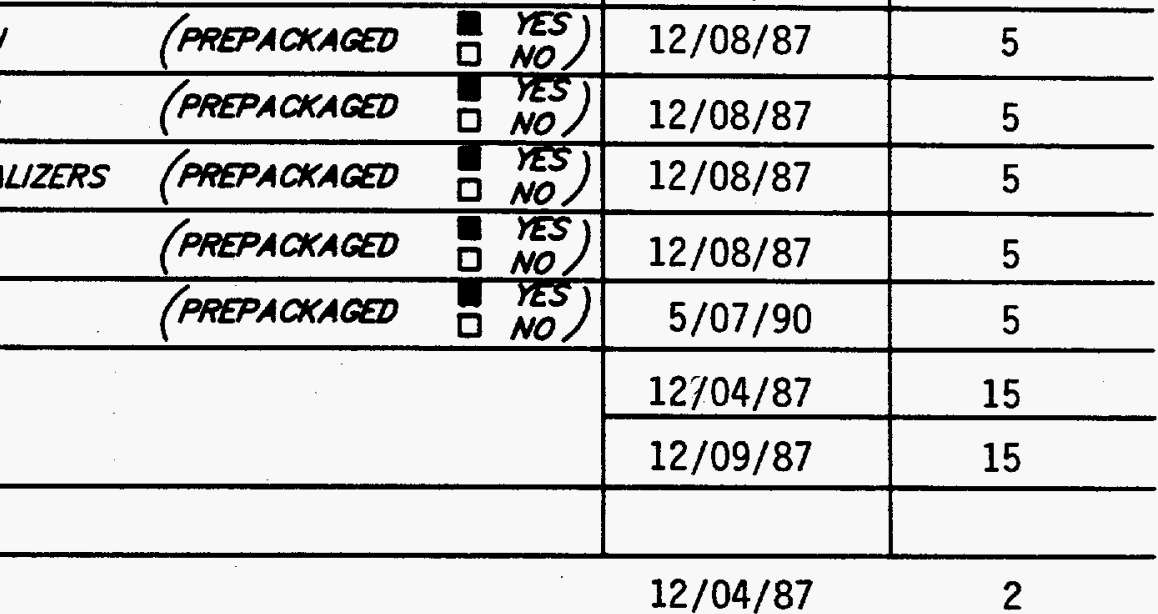

(PREPACKAGED

GROUT

WELL COVERS

SURFACE CASING

COMMENTS:

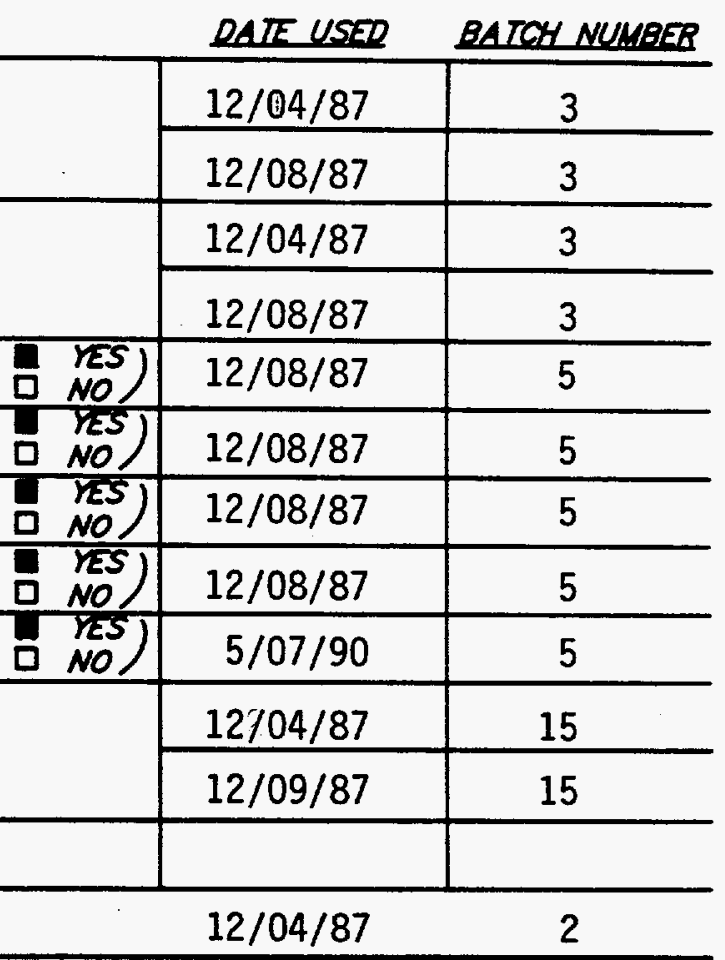

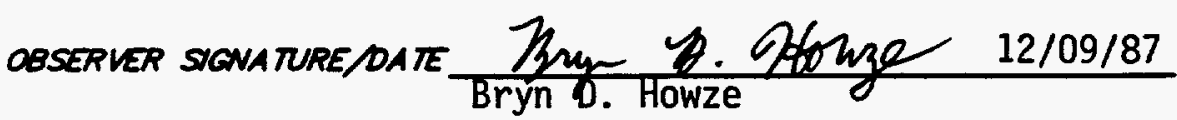




\section{POST-WELL COMPLETION CHECKLIST}

\section{POST-MELL COMPLETION TASKS}

1. MUO SCRAPED FRON AUGERS SAMPLERS, ANO MLL OTHER EOUIPWENT.

$12 / 09 / 87 \quad B D H$

2. ALL WUD FRON RIG ANO EQUPAMENT SCRAPINCS ANO

12/09/87 BDH
CUTINOS DISPOSED OF IN ACCORDANCE WTH THE SPECATCA IION PROMDED.

3 mEL OEVELORO IN ACCOPOANCE WTH THE SPECARCA TON

5/07/90 DCL PROVOED AND DETAKS OF THE OEVZZOPUENT ACTUT RECORDED.

4. DRULNG STE PROPERLY CLEANED UP AFTER COWPLETION OF MIL INSTALLATION.

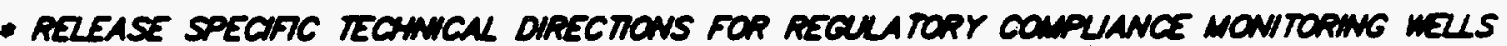
PHASE 1, OAK RHDEE NAMONAL LABORATOPY, OAK RIDEE WO K-4147, APRK 1987.

COSERVER STONATRE/OATE

Buy 2 .

Oolone $12109 / 87$

Bryn DJ Howze

$\frac{\text { D.Chavles Sutle }}{\text { D. Charles Lytle }}$ 


\section{MONITORING WELL \\ DEVELOPMENT FORM}

DEVELOPMENT DETAILS

METHOD OF

DEVELOPMENT: Surging and Pumping

DEVELOPMENT

BEGAN DATE:

$4 / 06 / 90$

TME:

DEVELOPMENT

ENDING DATE:

$5 / 07 / 90$

OEVELOPMENT

OBSERVED BY:

D. Charles Lytle

ONE WELL VOLUME: 31.2 GALLONS

TOTAL GALLONS PUMPED: 564 TOTAL WELL VOLUMES PUMPED:

18.1

INITAL PH: 7.5

FINAL PH: 7.7

INITAL CONDUCTUTY (NS/CM): 769

FNAL CONOUCTUTY $(\mu S / \mathrm{cm}): 549$

DESCRIPTION OF INITAL TURBIDITY: Cloudy

DESCRIPTION OF FINAL TURBIDITY: Clear

FNAL MEASURED TURBIDITY:

2.0 NTU's

WELL APPROVED BY: R. C. Williams MMES

\begin{tabular}{|c|c|c|}
\hline $\begin{array}{l}\text { ODOR. } \\
\text { OF MATER: }\end{array}$ & None & \\
\hline $\begin{array}{l}\text { WA TER } \\
\text { D/SCHARGED } \\
\text { TO: }\end{array}$ & $\begin{array}{l}\triangle \text { GROUND SURFACE } \\
\text { STORM SEMERS } \\
\text { D DRUMS }\end{array}$ & $\begin{array}{l}\text { 口 TANK IRUCK } \\
\text { STORAGE TANKS } \\
\text { 口 OTHER }\end{array}$ \\
\hline
\end{tabular}

INITAL PRE-OEVELOPMENT

WATER DEPTH:

21.6 feet from ground surface.

DEVELOPMENT OBSERVATIONS

OBSERVER SIGNATURE/DATE D. Chaules Syete 5/07/90

PAGE 14 of 21. 


\section{MONITORING WELL DEVELOPMENT PROGRESS}

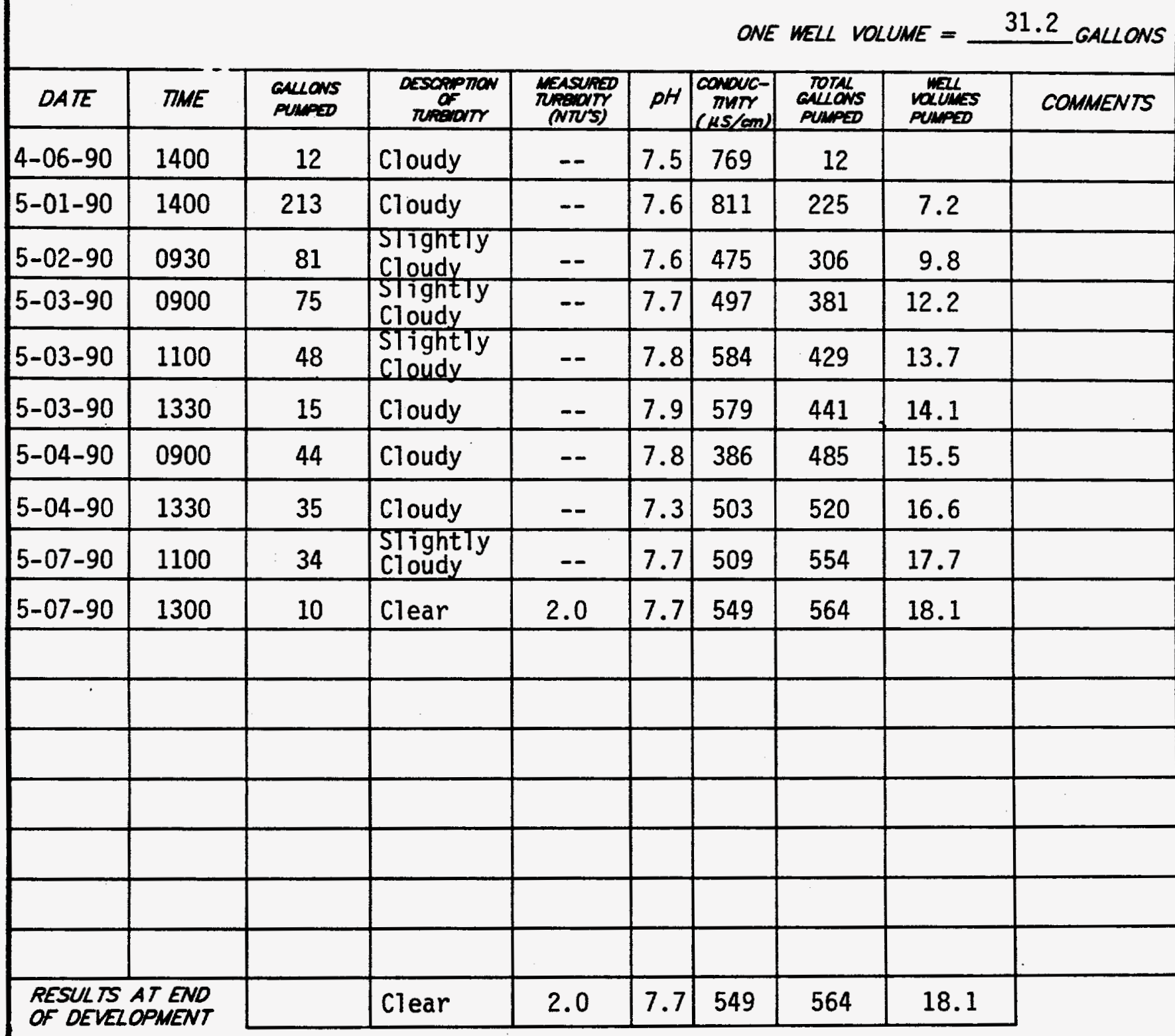

COMMENTS Nice producer, stays clear after surging. Passed with 2.0 NTU's and moved to another hole. 


\title{
HYORAULIC CONDUCTIVTY CALCULATIONS
}

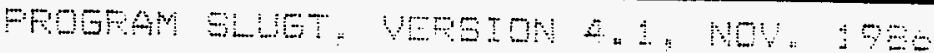

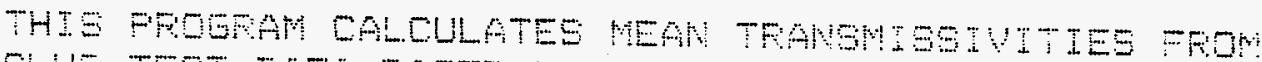

SLUETEST DATA BAEED ON TWO ANAWTICAL APPPOACHE:

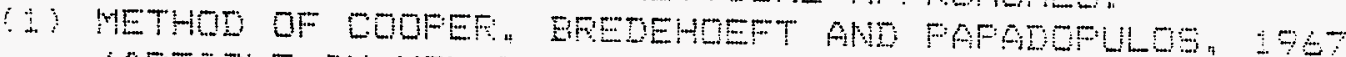
AARTCLE JN VOL S NO. I OF MTE ENTETED "RESFONSE OF A FINTE DIAHETEF WELI TO AW INOTANTANEOUE
WHFEE OF WATE"

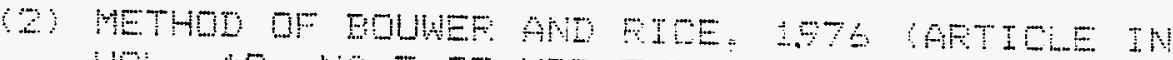

VOL: 2 : NG. OF WRE ENTTTLES

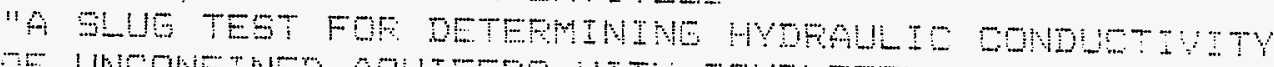

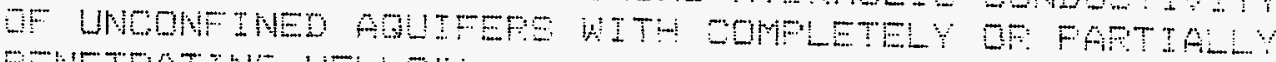

FENETGATINE WELSS"

WELL NO.:

DATE OF TEST: $=15 / 90$

PETECT MO: EZ-OI

DLEMT: MHES

ITE LOCATIUH

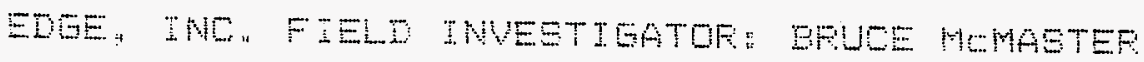

\section{INFUT DATA ARE:}

INVEF CASTNE DIAMETEF $=4.00$ INCHES

INNEF SCEEEN OF OFEN-HOLE DYAMETEF = 4 "OO TNCHES

DIAMETEF OF DFILLED WOLE =

LENGTH OF SOREEN OR INTAKE FORTION $=20.90 \mathrm{FEET}$

DEFTH FEOM STATIC LEVEL TO EOTTOM OF SCFEEN = 22. OO FEET

THTNESE OF SATUFATED AUUIFEF ZONE = 20.80 FEET

DEFTH TO STATIC WATEF LEVEL EELOW FEF FOTNT = "9? FEET

ESTIMATE POFOEITY OF GFAVEL PAEK = 30

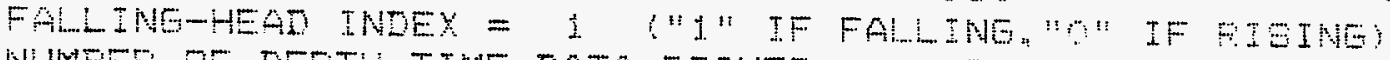

NUMEEF OF DEFTH-TIME DATA FOINTS $=20$

HO AAS COMPUTED FROM INTEFCEFT OF FLOT OF LOECH VE. TIME

SUCCESSIVE COMFUTED

VALUES FOF HO

(FEET)

2.3483

2.243 


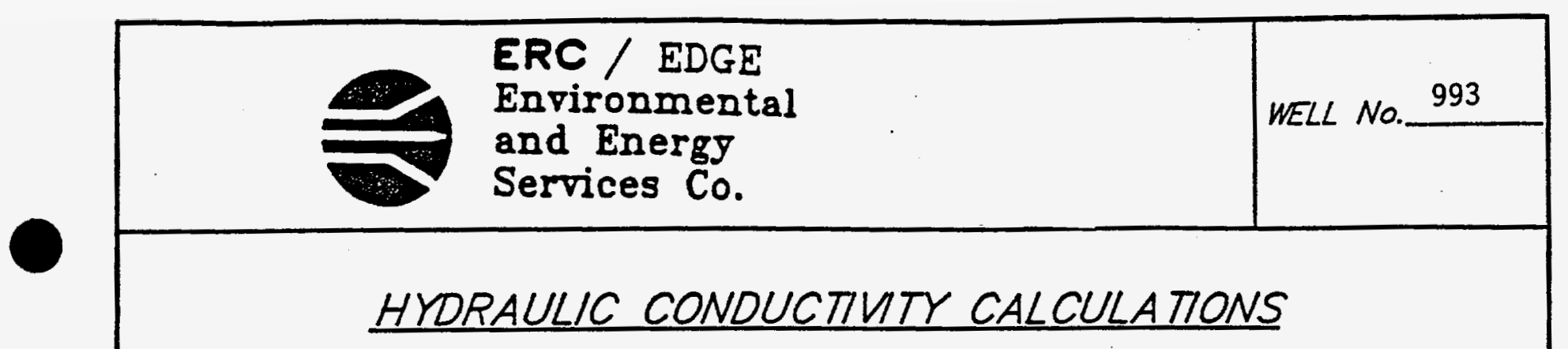

\begin{tabular}{|c|c|c|}
\hline $\begin{array}{l}\text { TIHE } \\
\text { SECOND }\end{array}$ & $\begin{array}{c}\text { DEFTH TO WATES } \\
\text { (FEET }\end{array}$ & $\begin{array}{r}\text { YEA } \\
\text { (FEET: }\end{array}$ \\
\hline 10.00 & $\Xi .15 \%$ & 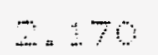 \\
\hline 20.10 & Э ०ग & - \\
\hline 70,10 & 270 & $\therefore 90$ \\
\hline 40,00 & $\therefore 790$ & 2.10 \\
\hline 30.00 & 2.590 & 1470 \\
\hline मी & 2.59 & 1.40 \\
\hline $7 \equiv .00$ & 2.460 & \pm .480 \\
\hline $90: 00$ & $=540$ & \rfloor$=760$ \\
\hline 105.00 & $\therefore=30$ & 1.250 \\
\hline 120.00 & 2100 & 1.50 \\
\hline 50,90 & 1.930 & -90 \\
\hline 190,00 & 1.750 & 770 \\
\hline 240,00 & 1.490 & .510 \\
\hline 700.0 & \pm .30 & $=380$ \\
\hline 3600 & 1.250 & $=270$ \\
\hline 420.00 & 1.170 & $=190$ \\
\hline 480.00 & 1.140 & .160 \\
\hline 540,00 & j. & .20 \\
\hline 4000 & +050 & .070 \\
\hline 720.00 & 1.000 & .020 \\
\hline
\end{tabular}

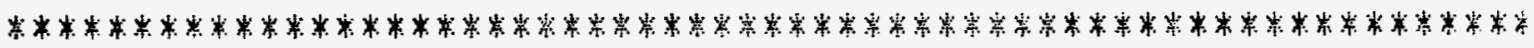

METHOD OF EQUUEF: AND FICE

COMFUTED FESLLTS USINE DIAMETEF OF DETLLED HOLE:

FEFMEAEILITY $=1.20 E-O S$ FT/SECOND $=3.67 E-04$ CWI $/ 5 E$

TFANSMISSIVITY $=2.51 E-64$ FTW

PAGE 17 of 21 


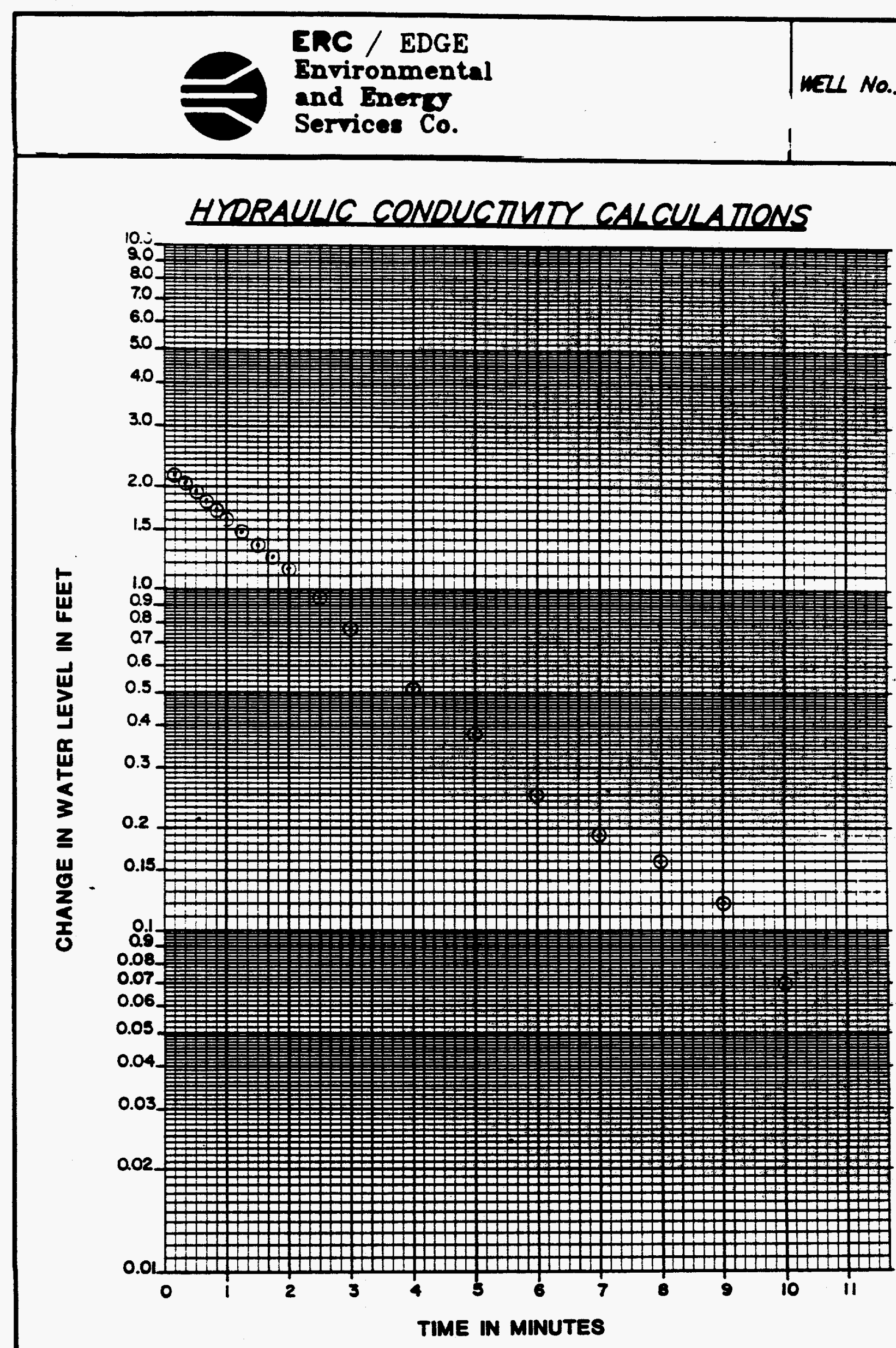

PACE 18 of 21 
T. MCIICONSULTING ENGINEERS, INC. NASHVILLE KNOXVILLE HUNTSVILLE LOUISVILLE (615) $966-9788$

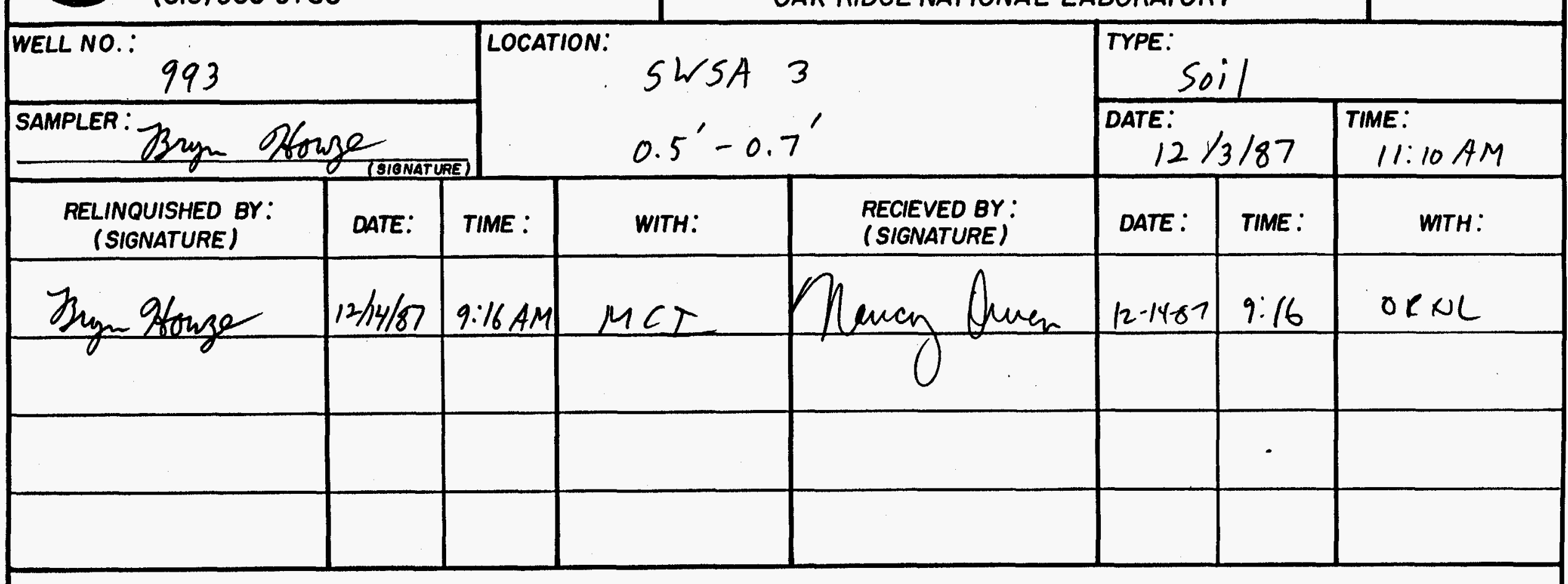

REMARKS: 


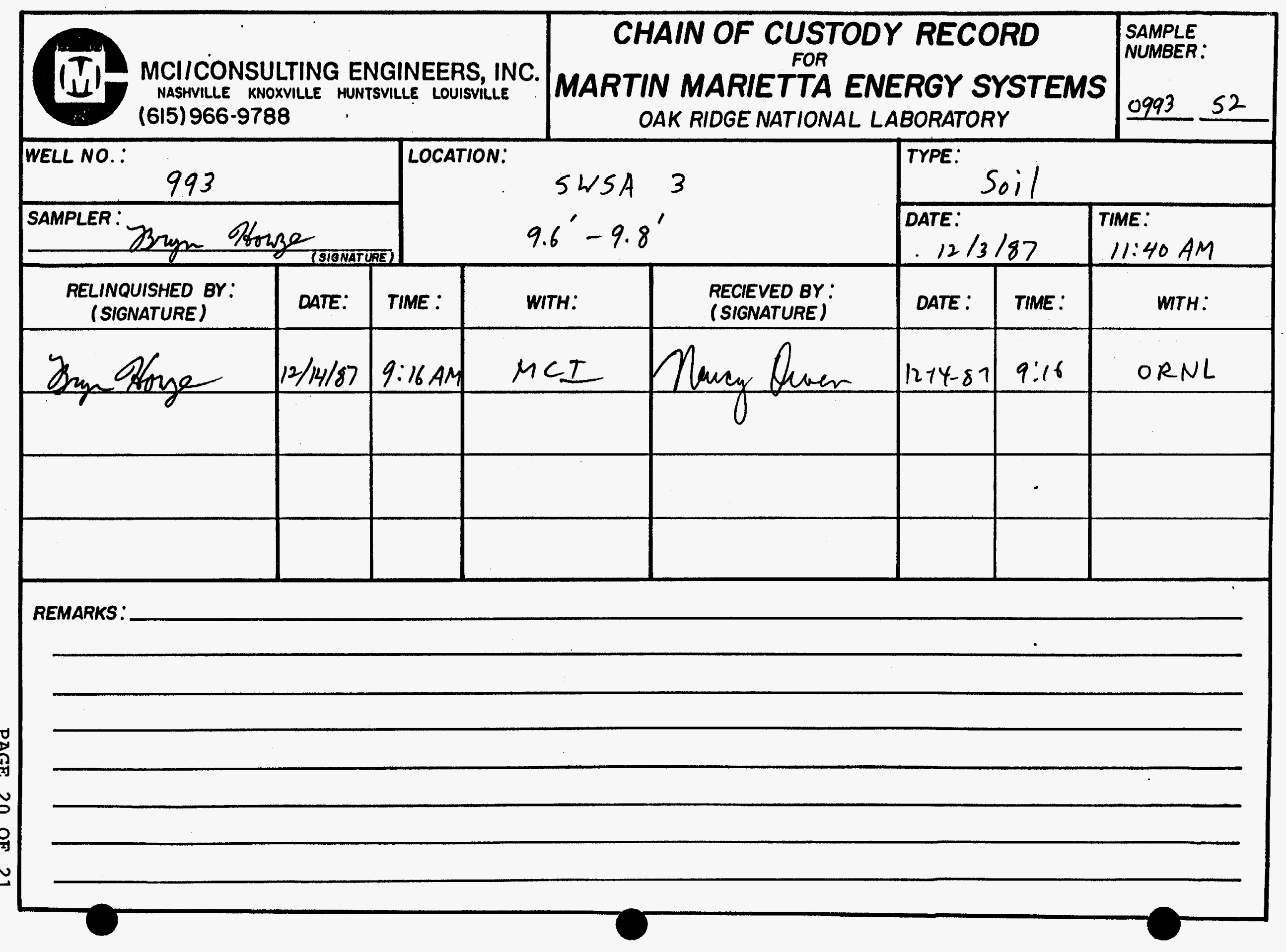


$|\bar{T}| \overline{1}$ MCIICONSULTING ENGINEERS, INC. NASHVILLE KNOXVILLE HUNTSVILLE LOUISVILLE (615) 966-9788

\begin{tabular}{|c|c|c|c|c|c|c|c|}
\hline \multicolumn{2}{|l|}{ WELL NO.: 993} & \multirow{2}{*}{\multicolumn{3}{|c|}{ LOCATION: }} & \multicolumn{3}{|c|}{$\begin{array}{l}\text { TYPE: } \\
\\
\end{array}$} \\
\hline SAMPLER: $73 y_{2}-7$ & $\sum_{\operatorname{siONAT}}^{2}$ & & & & \multicolumn{2}{|c|}{$\begin{array}{c}\text { DATE: } \\
12 / 7 / 87 \\
\end{array}$} & \multirow{2}{*}{$\begin{array}{c}\text { TIME: } \\
\text { II: } 30 \text { AM } \\
\text { WITH: }\end{array}$} \\
\hline $\begin{array}{l}\text { RELINQUISHED BY: } \\
\text { (SIGNATURE) }\end{array}$ & DATE: & TIME: & WITH: & $\begin{array}{l}\text { RECIEVED BY: } \\
\text { (SIGNATURE) }\end{array}$ & DATE: & TIME: & \\
\hline Bry Ofone & $12 / 14 / 87$ & $9: 16 \mathrm{AM}$ & $M^{c} I$ & Caven Arum & $1201+-81$ & $9: 16$ & ORNL \\
\hline & & & & U & & & \\
\hline & & & & & & - & \\
\hline & & & & & & & \\
\hline
\end{tabular}

REMARKS: 
ERC / EDGE

Environmental

and Energy

Services Co.

\subsection{General Information}

\subsection{We11 Location}

Monitoring well number 994 is located in WAG 3 . It is located in the northeast corner of the contractors landfill. The location is shown on ORNL drawing number C3E20004 A075. Survey coordinates for this

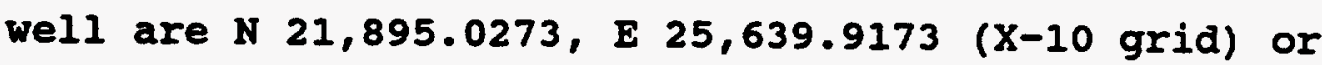
latitude $35^{\circ}-55^{\prime}-05.02^{\prime \prime}$ and longitude $84^{\circ}-19-54.52^{\prime \prime}$. Coordinate data were provided by Martin Marietta Energy systems. The method used for conversion from X-10 grid to Tennessee-Lambert State Plane coordinates came from the publication "Tennessee Valley Authority Data Services Branch and Mapping Services Branch, Oak Ridge, Tennessee, DOE Plant Control, November 6, 1985, Field Book: Ess-3115, pp. 1-20." The latitude and longitude were calculated by Adams Craft Herz Walker Engineering, Inc., using methods from the U.S. Coast and Geodetic Survey Publication 62-4, "State Plane Coordinates by Automatic Data Processing."

\subsection{Drilling Information}

Well number 994 was drilled by A. L. Clark Drilling Services Co. A Gus Pech rig was used to drill this boring for monitor well installation under operation of A. L. Clark III with the assistance of Leo Johnson. Drilling commenced on 12-6-87 and was finished on 1-4-88. Paragraph 2.4.1 includes, a detailed discussion of the well installation and $a$ well schematic is included on the well installation/ completion form. A synopsis of the drilling activity 
follows. This information was typed directly from field notes and was edited only when necessary for clarification.

12-16-87 The Gus Pech drill rig was steam cleaned and mobilized to the staked location and set up. The boring was drilled from 0.0 feet to 16.8 feet with 14 -inch augers.

12-17-87 The boring was deepened to 17.6 feet with 14-inch augers.

12-18-87 Set and grouted 19 feet of 10-inch surface casing.

12-21 - 12-22-87 The containment box was cleaned out. 12-28-87 Set 60 feet of 4-inch stainless steel casing and grouted annulus.

12-31-87 steam cleaned drill rods and bit and drilled from 60.0 feet to 80.5 feet with a $37 / 8 "$ tricone bit.

1-4-88 Checked water level, blew hole dry and pulled rig off site.

This well was logged by ERC Environmental and Energy Services Co., Inc., hydrogeologist Bryn D. Howze. All well construction materials and supplies were from Martin Marietta Energy Systems approved batches. The batch origin of individual items is shown on the included Monitoring Well Materials Certification form. 
ERC / EDGE

Environmental

and Energy

Services Co.

\subsection{Technical Information}

\subsection{Decontamination Procedures}

The drilling rig, down hole tools, surface casing, stainless steel screen, stainless steel casing, centralizers, and stainless steel silt trap underwent the cleaning decontamination procedures outlined in the drilling specifications (Release specific Technical Directions for Regulatory Compliance Monitoring Wells Phase 1, Oak Ridge National Laboratory, Oak Ridge, w.O. K-4147, April 1987, pgs. 2-4). A checklist of the cleaned materials is included with this data package.

\subsection{Ceology}

WAG 3 is located in Melton Valley which is in the Valley and Ridge Physiographic Province of East Tennessee. WAG 3 is underlain by limestone, siltstone and shale of the Middle Ordovician Chickamauga Group. The Chickamauga Group consists of eight units, designated by letters "A" to "H" (Stockdale, 1951). WAG 3 is underlain by units E, F, G and H. These units consist of thin bedded nodular limestone with clay and shale partings. A portion of unit $H$ and unit $F$ consists of calcareous siltstone alternating with beds of olive gray to maroon shale. Strike and dip varies from $N 45^{\circ} \mathrm{E}$ to $\mathrm{N} 55^{\circ} \mathrm{E}$ and $25^{\circ}$ to $35^{\circ}$ southeast, respectively. 


\subsection{Bample Collection}

A drill water sample was collected from the water pump on the drill rig on 12-31-87. Analytical results for the water sample described above can be obtained from the Remedial Action Program data base at ORNL.

\subsection{Installation and Development}

\subsubsection{Installation}

This was an open hole or "Type C" well, without a stainless steel screen. A 14-inch diameter boring was augered from ground surface to bedrock (17.6 feet). A 10-inch diameter string of decontaminated steel surface casing was installed and grouted in place. The surface casing minimizes potential cross contamination between the regolith and bedrock water bearing zones. The air rotary method was then used to drill an 8-inch diameter boring to a depth of 60.0 feet. A 4-inch diameter stainless steel casing was installed and a 1.1-foot bentonite seal installed from 58.0 feet to 59.1 feet. The boring was tremie grouted from the top of the bentonite seal at 58.0 feet to ground surface. The air rotary method was then used to drill a 3 7/8-inch diameter boring (open hole interval) from the bottom of the 4-inch diameter stainless steel casing at 60.0 feet to a total depth of 80.5 feet. A detailed schematic of the well is included on the well installation/completion form. 
ERC / EDGE

Environmental

and Energy

Services Co.

\subsubsection{Well Development}

Well number 994 was developed to remove arill cuttings, silt, and other fines. The monitoring well was developed using a Geoguard pump with an air compressor. All pumps were cleaned prior to use according to specified cleaning procedures (see Paragraph 2.1). The well was developed until a measured total of 340 gallons of water had been evacuated and the clarity of the discharge water was approved by the company representative. The final turbidity value measured at completion was 2.0 NTU's. A development form showing the exact method of development and other pertinent data is appended.

2.4.3 Installation of Dedicated Yonitoring well Pump

After the well was developed, a Geoguard Model No. 5614 dedicated monitoring well pump was installed on 4-17-90 at a depth of 78.2 feet below ground surface. These pumps are decontaminated at American sigma and are sent prepackaged. A copy of the pump certification is kept on file at ORNL.

\subsection{Hydraulic Conductivity resting}

Well number 994 was tested for the determination of hydraulic conductivity of the aquifer in the vicinity of the well screen. This was accomplished by instantaneously adding a known quantity of water to the monitoring well and measuring the recovery of the water level over time. The changing water levels were 
measured using a Druck 15 psig pressure transducer and an Omnidata Datapod II data recorder. The hydraulic conductivity value of $7.01 \times 10^{-5} \mathrm{~cm} / \mathrm{second}$ (shown as permeability on the hydraulic conductivity calculations printout attached) was calculated using the Bouwer and Rice method. A computer printout of the hydraulic conductivity calculations is included in this data package. 


\section{PRE-DRILLING CHECKLIST FOR MONITORING WELLS}

\section{PRE-DRILLING TASKS}

1. EXCAVATION PERMIT OBTAINED.

2. ALL EQUIPMENT HAS BEEN CLEANED BEFORE DRILLNG.

30. SCREEN AND CASNGS HAVE BEEN WASHED, STEAMED, RINSED WIH DE-1ONIZED OR DISTLLED WATER, RINSED WTH ISOPROPR ALCOHOL MPAPPED WIH PROTECTIE COVERING AND STORED OFF THE GPOUND.

36. PRE-PACKAGED SCREENS, CASINGS AND CENTRALIZERS MERE USED.

4. MORK AREA FOR SAMPLE EXAMINA MON COVERED WTH CLEAN POC KETHRENE.

5. CLEAN KNIVES GOVES, SAMPLE JARS AND LABEZS ON-HAND.

6. POLYETHRENE COVER IN PLACE OVER HOLE.

AOOIMONAL NOTES/OBSERVA MONS.
COMPLIANCE

DATE INITALS

$12 / 16 / 87$ BRH

$12 / 16 / 87 \quad B D H$

$\underline{N / A}$

$12 / 29 / 87$

$\underline{12 / 16 / 87}$

BDH

$12 / 16 / 87$

BPH

$12 / 16 / 87$

BDA

AODITONAL NOTES/OBSERVAMONS.

(1)

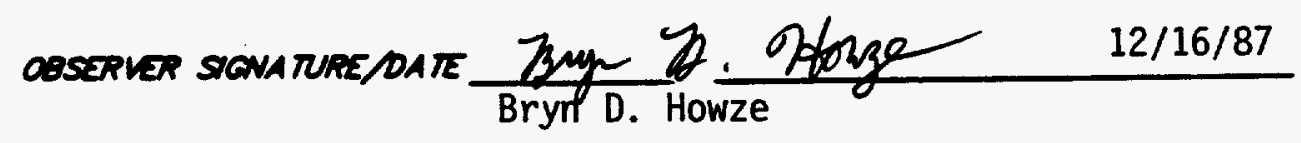


DECONTAMINATION CHECKLIST

DRILLING EQUIPMENT

\begin{tabular}{|c|c|c|c|c|c|}
\hline EQUIPMENT & SCRAPE & $\begin{array}{l}\text { STEWW } \\
\text { CLEWN }\end{array}$ & $\begin{array}{l}\text { STEW } \\
\text { RINSE }\end{array}$ & $\begin{array}{c}\text { ISOPROPN } \\
\text { ALCOHOL } \\
\text { RINSE }\end{array}$ & $\begin{array}{c}\text { DEIONIZED } \\
\text { WATER } \\
\text { RINSE } \\
\end{array}$ \\
\hline RIG & $x$ & $x$ & $x$ & $N / A$ & $N / A$ \\
\hline AUGERS & $x$ & $x$ & $x$ & $x$ & $x$ \\
\hline BITS & $x$ & $x$ & $x$ & $x$ & $x$ \\
\hline ROOS & $x$ & $x$ & $x$ & $x$ & $x$ \\
\hline SAMPLERS & $x$ & $x$ & $x$ & $x$ & $x$ \\
\hline PIPES & $x$ & $x$ & $x$ & $x$ & $x$ \\
\hline WORK TOOLS & $x$ & $X$ & $x$ & $x$ & $x$ \\
\hline AUGER PINS & $x$ & $x$ & $x$ & $x$ & $x$ \\
\hline & & & & & \\
\hline & & & & & \\
\hline & & & & & \\
\hline & & & & & \\
\hline
\end{tabular}

OBSERVER SIONATUREAOATE $\frac{7 \text { Gy D. Offorye 12/18/87 }}{\text { Bryn D. Howze }}$ 
ORNL MONITORING WELL LOG

LOCA ITON: SWSA 3

ORILLER: Avery L. Clark III

HELPER: LeO Johnson

DRILL: GUS Pech
PACE 1 or 2

OATE: START: $12 / 16 / 87$

FNISH: $1 / 04 / 88$

LOGGED BY: Bryn D. Howze

HEALTH PHYSGCST: PaUT Eldridge

LUBRICANT TPE: Silicon Stopcock

TPE: Drilling Water

No. SAMPLES TAKEN: 1 (one)

CONTAINMENT TPE: Plastic, Containment Pan, Containment Box

THCXNESS OF SOLL (REFUSNL DEPTH): $16.8^{\prime}$

OEPTH DRILLO IN ROCK:

TOTAL DEPTH OF MELL.

$63.7^{1}$

$80.5^{\prime}$
DRULNG RUID SAMPLES.

TrPE: Water

DATE: $12 / 31 / 87$

\begin{tabular}{|c|c|c|c|c|}
\hline \multicolumn{2}{|c|}{ 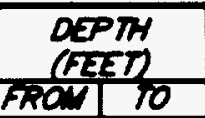 } & $\begin{array}{c}\text { SAMPLE } \\
\text { (NUIMESR } \\
\text { INTERVAN) }\end{array}$ & $\begin{array}{c}\text { PERCENT } \\
\text { RECOVRR } \\
\text { SPYUT SPOONUS) }\end{array}$ & SOK BEDROCK DESCRIPTON \\
\hline 0.0 & 0.3 & & & Topsoil, medium to dark brown, with roots and \\
\hline & & & & rock fragments, firm. \\
\hline 0.3 & 4.8 & & & Silt, slightly sandy, light brown, mottled \\
\hline & & & & black, orange, yellow, with weathered rock \\
\hline & & & & fragments, very stiff. \\
\hline 4.8 & 6.5 & & & Weathered limestone and clay, slightly silty; \\
\hline & & & & limestone, light gray, (weathered) to \\
\hline & & & & greenish gray (fresh) appears as float in \\
\hline & & & & clay that is medium brown to orange brown, \\
\hline & & & & mottled black, yellow, red, greenish gray, \\
\hline & & & & stiff. \\
\hline 6.5 & 16.8 & & & Clay, slightly silty, medium brown to orange \\
\hline & & & & brown, mottled black, yellow, red, greenish \\
\hline & & & & gray, very stiff. \\
\hline 16.8 & 17.6 & & & Limestone, weathered, light gray. \\
\hline & & & & Auger refusal at $17.6^{\prime}$ \\
\hline & & & & No detailed lithologic descriptions available \\
\hline & & & & from $17.6^{\prime}$ to $80.5^{\prime}$ due to use of contain- \\
\hline & & & & ment box. \\
\hline 17.6 & 19.0 & & & Soft drilling. \\
\hline 19.0 & 24.0 & & & Hard dritling. \\
\hline
\end{tabular}




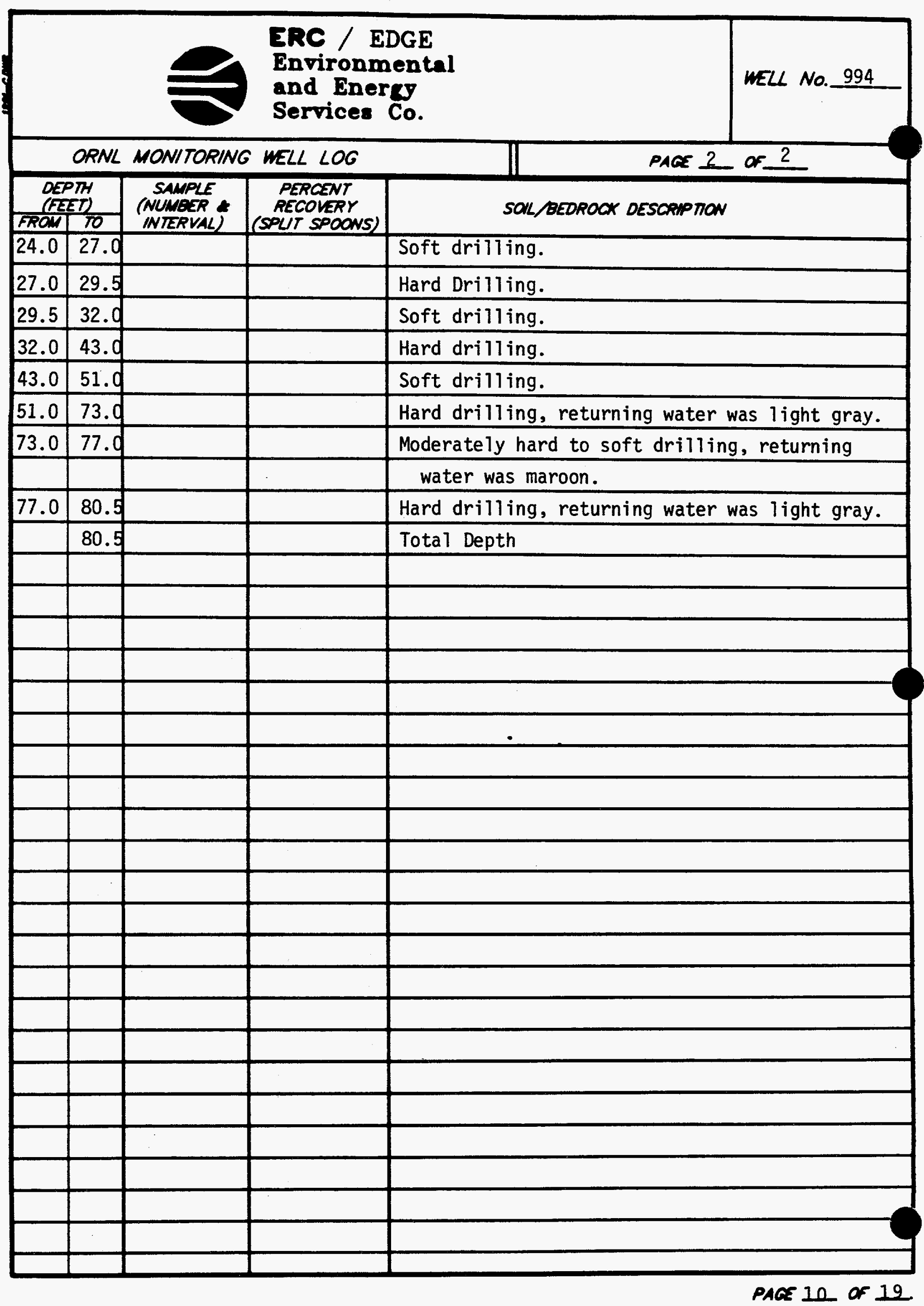




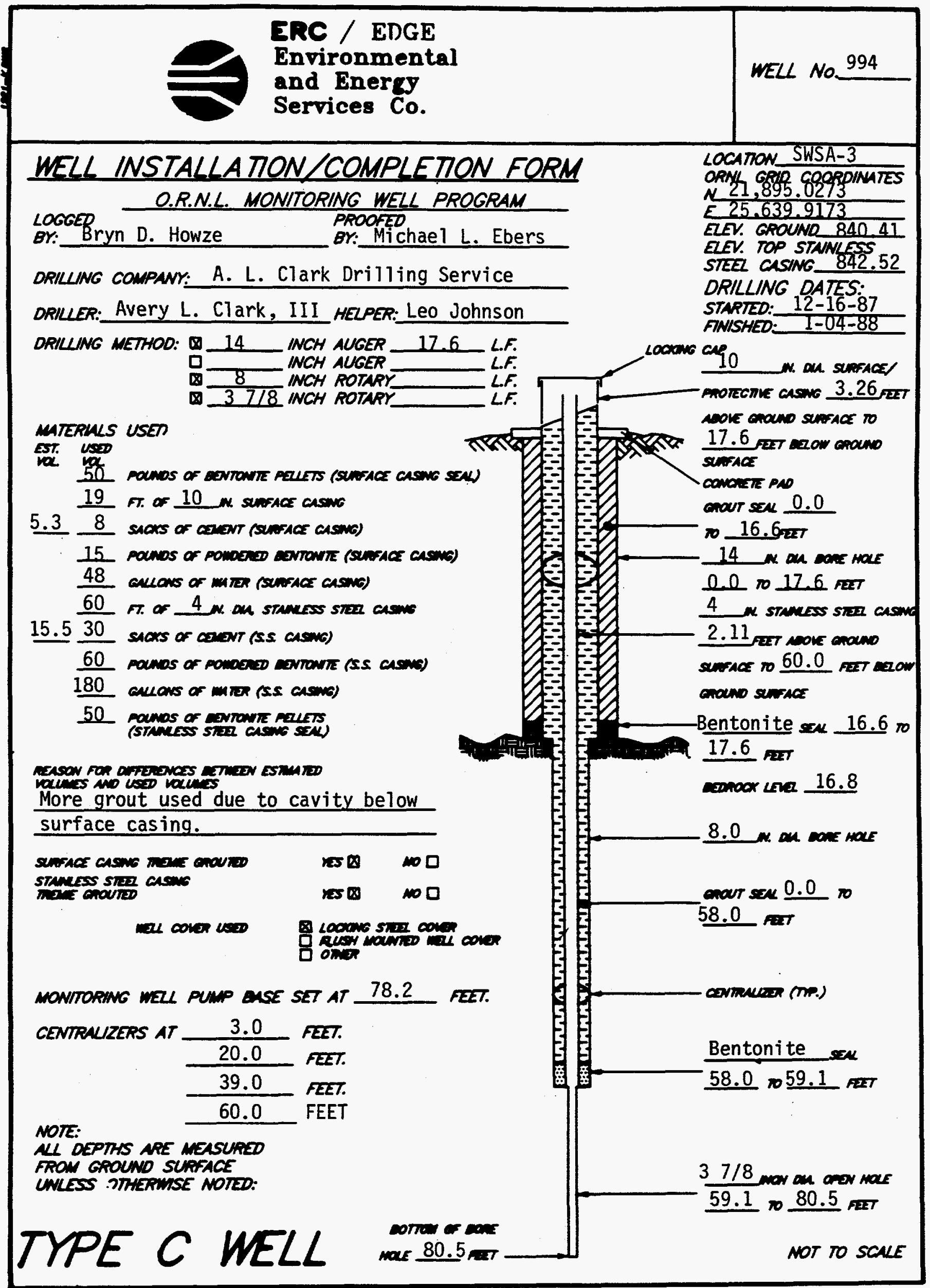

PAGE 11 of 19. 


\section{MONITORING WELL MATERIALS \\ CERTIFICATION}

\begin{tabular}{|c|c|c|}
\hline ITEM MA TERIAL & DATE USED & BATCH NUMBER \\
\hline \multirow{2}{*}{ SAND } & $12 / 18 / 87$ & 3 \\
\hline & $12 / 29 / 87$ & 3 \\
\hline \multirow{2}{*}{ BENTONITE } & $12 / 18 / 87$ & 3 \\
\hline & $12 / 29 / 87$ & 3 \\
\hline $\begin{array}{l}\text { STAINLESS STEEL SCREEN (PREPACKAGED } \\
\text { DES }\end{array}$ & $12 / 29 / 87$ & \\
\hline STAINLESS STEEL CASING (PREPACKAGED D NOS & $12 / 29 / 87$ & 5 \\
\hline STAINLESS STEEL CENTRALIZERS (PREPACKAGED D VES & $12 / 29 / 87$ & 5 \\
\hline $\begin{array}{lll}\text { STAINLESS STEEL CAPS } & \text { (PREPACKAGED } & \text { YES } \\
\text { NO }\end{array}$ & $12 / 29 / 87$ & 5 \\
\hline (PREPACKAGED Q NOS & $4 / 17 / 90$ & 5 \\
\hline \multirow{2}{*}{ GROUT } & $12 / 18 / 87$ & 15 \\
\hline & $12 / 29 / 87$ & 15 \\
\hline \multicolumn{3}{|l|}{ WELL COVERS } \\
\hline SURFACE CASING & $12 / 18 / 87$ & 02 \\
\hline
\end{tabular}

COMMENTS:

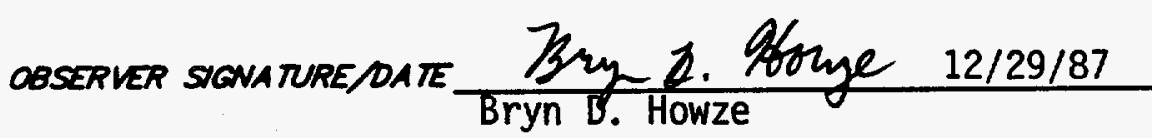




\section{POST-MELL COMPLETION CHECKLIST}

\section{POST-WELL COMPLETION TASKS}

COMPLIANCE

DATE INITALS

1/04/88 BDH

$1 / 04 / 88 \quad$ BDH

$4 / 17 / 90$

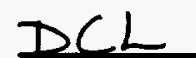

3. WZL OEVZZORED NN ACCOPOANCE MTH THE SPECATCA NON* PROVOED ANO DETAKS OF THE DEVELOPMENT ACTKTH RECOROED.

4. DRULNG STE PROPERY Y CLANDD UP AFTER

$1 / 04 / 88$

BDH conplemon or "IIL ANTALABON.

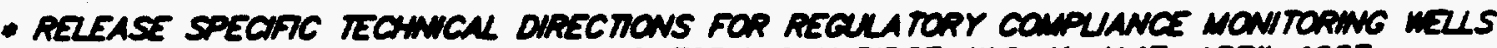
PHASE i, OAK RHOCE NATIONAL LABORA TORY, ONK RDEE, M. K-4147, APRK 1987.

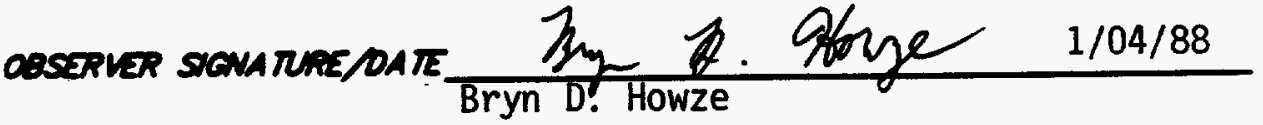

D. Chanlas Suele

$4 / 17 / 90$

D. Charles Lyt'le 


\section{MONITORING WELL DEVELOPMENT FORM}

DEVELOPMENT DETAILS

METHOD OF

DEVELOPMENT: Surging and Pumping

DEVEL OPMENT $\quad 4 / 04 / 90$ TME:

OEVELOPMENT

ENOING DATE: $\quad 4 / 17 / 90$

DEVELOPMENT

OBSERVED BY:

D. Charles Lytle

ONE WELL VOLUME: 38.0 GALLONS

TOTAL GALLONS PUMPED: 340 TOTAL WELL VOLUMES PUMPED: 9.0

INITAL PH: 7.5 FNAL PH: 7.5

INITAL CONOUCTUTY $(\mu \mathrm{s} / \mathrm{cm}): 774$ FNAL CONDUCTUTY $(\mu \mathrm{s} / \mathrm{cm}): 834$

DESCRIPTION OF INITAL TURBIOITY: Milky

DESCRIPTION OF FINAL TURBIOITY:_Clear

FINAL MEASURED TURBIDITY:

2.0 NTU's

WELL APPROVED BY

R. C. Williams MMES

\begin{tabular}{lll} 
ODOR & NONe & \\
OF MATER: & GROUND SURFACE & 口 TANK TRUCK \\
\hline WA TER & STORM SEWERS & STORAGE TANKS \\
DISCHARGED & D DRUMS & 口 OTHER \\
TO: &
\end{tabular}

INITAL PRE-DEVELOPMENT

WATER DEPTH:

22.0 feet from ground surface.

DEVELOPMENT OBSERVATIONS

OBSERVER SIGNATURE DATE D.Choules Bytele 4/17/90

D. Charles Lytle 


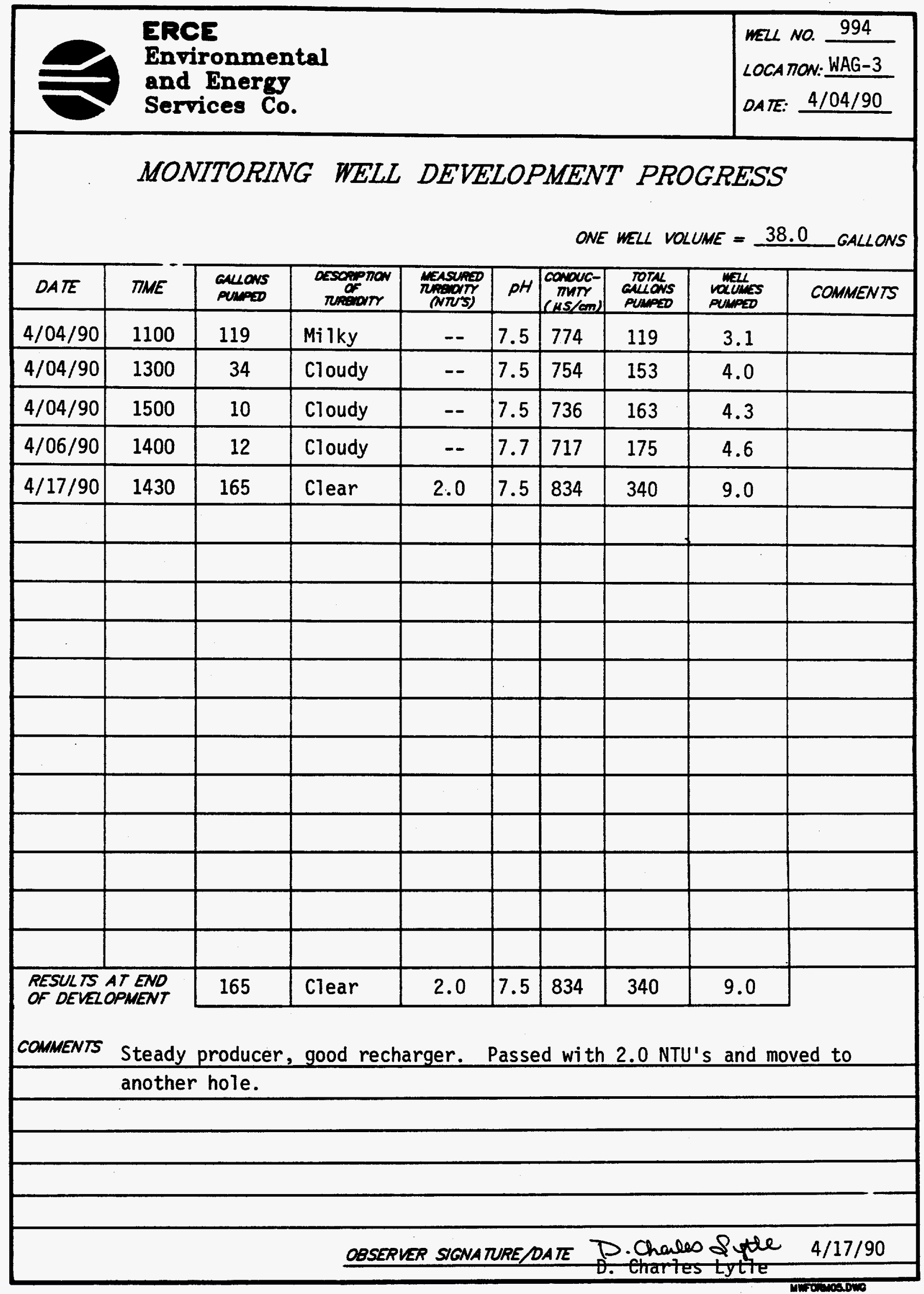

PAGE 15 of 19. 


\section{HYORAULIC CONDUCTIVTY CALCULATIONS

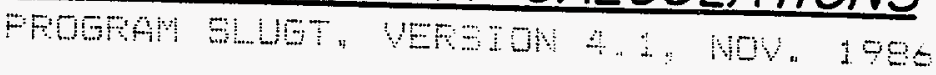

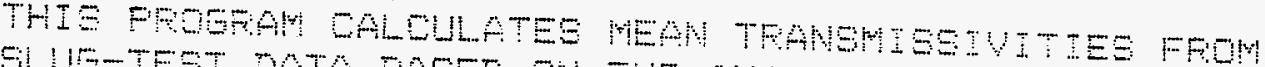

SLUSTEST DATA BASED ON THO ANALYTAAL AFFFOACHES:

(1) NETHOL UF COOFER EREDEHOEF AND FAFADOFULOS 1967

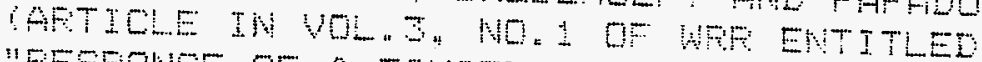

"AESFONSE OF A FTUTE DUMETEF WELL TO AN INETANTHEDUE

(2) WETHT DF BOUWE PUD FICE 1972 ARTCEE IN

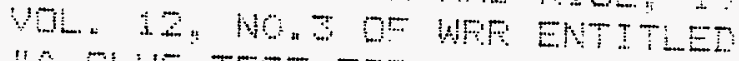

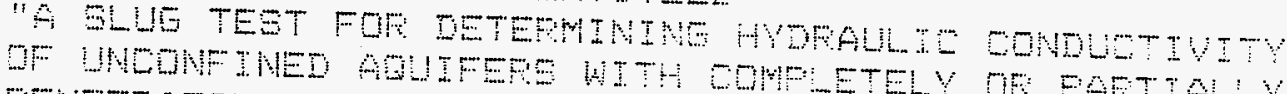

PENETPATINE HELLS:

MELL NO.: 794

DATE OF TEST: $=1 D Y O$

PEOTEC NO : E221-00

CLENT: MHES

\section{BTE LOGATION: $x$}

EDEE, INE. FIELD INUESTIGATCE: BUUCE MCMAOTES

\section{INFUT DATA AFE:}

INNEF CASTNG DIANETEF = 4.OO INCHES

INME SCFEEN DF OFEN HOLE DIAMETEF: =

DIANETEE OF DFILLED HOLE $=4.00$ TNCHES

LENETH OF SCFEEN OF: INTAKE FOFTION $=24.40$ FEET

DEFTH FNOM STATIC LEVEL TO EOTTOM OF SCREEK = 57.5O FEET

THTCNESS OF SATUFATED AQUIFEF ZONE = 21.40 FEET

DEFTH TO STATIC WATEF LEVEL EELOW FEF" FOINT = "B9 FEET

ESTIMATEO FOFOSTTY OF GFAVEL PACK = "30

FALLING-HEAD INDEX = 1 "1" TF FALLINE "O" IF FIEINE,

NUMEEF CF DFPTH-TTMF DATA FMTNTE = 3

HO WAE COMFUTES FFOM INTEFCEFT OF FLOT OF LOG

SULCESSIVE COMFUTED

YALUES FQR: HO

(FEET)

2.1309

2.1255 


\section{HYDRAULIC CONDUCTIVTY CALCULATIONS}

\begin{tabular}{|c|c|c|}
\hline SEcons & $\begin{array}{c}\text { DEPTH TO WOTEF } \\
\text { PEET! }\end{array}$ & $\begin{array}{r}\text { HEAD } \\
\text { HEET: }\end{array}$ \\
\hline मी & 3.990 & $\therefore 50$ \\
\hline 20,0 & 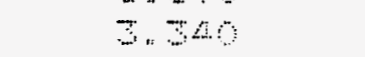 & 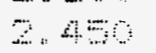 \\
\hline 80.0 & $\because 310$ & 2.40 \\
\hline 40.0 & 3.29 & $=40$ \\
\hline 50 “0 & $3 \quad 270$ & $\because 30$ \\
\hline का. ब & 3.250 & $\therefore .30$ \\
\hline $7=00$ & $\exists \quad 21$ & $\because \quad=$ \\
\hline 90.0 & $\because .70$ & 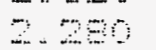 \\
\hline बि. & $=120$ & 23 \\
\hline 220,0 & 7 69o & $\therefore 290$ \\
\hline 150 \% & $\because=\operatorname{~बो~}$ & $\therefore$ I \\
\hline 180.00 & $=940$ & $\mathrm{O}$ \\
\hline 240,00 & $=790$ & \pm .9 \\
\hline आ० & 2.66 & 1.770 \\
\hline 30.00 & 2540 & $\therefore \angle E O$ \\
\hline 420.00 & 2.410 & $\triangle=20$ \\
\hline 480.90 & 2.33 & 1,440 \\
\hline 540.00 & 2.280 & $\therefore .790$ \\
\hline की० & 2.20 & ब. \\
\hline 720.0 & 2.050 & L. SO \\
\hline 540.00 & \pm .940 & $1=00$ \\
\hline 960.00 & 1840 & 950 \\
\hline 1090.00 & 1.750 & .80 \\
\hline 1200,00 & j. 420 & . 70 \\
\hline 130.0 & 1.610 & .720 \\
\hline 1440.00 & 1.540 & .550 \\
\hline 1560.00 & 1.520 & $: \leq 30$ \\
\hline 1680.0 & 1.450 & .560 \\
\hline 1800.00 & 1.410 & .520 \\
\hline 1920.00 & 1.340 & .450 \\
\hline 20,00 & 1.260 & .770 \\
\hline 2160.00 & 1.240 & .350 \\
\hline
\end{tabular}

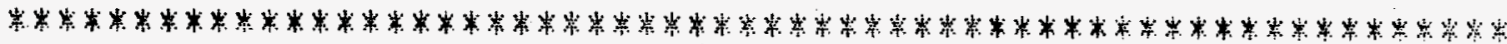

FETHOD OF EOUWEF AND FICE

COMFUTED FESULTS USINE DIAMETEF OF DFILLED HOLE:

FEFMEAEILITY $=$ 2.3OE-OSFT/SECOND =7.OLE-OS CM/SEO

TFANSMISSIUITY $=4.92 E-05$ FTWW2:SECOND 


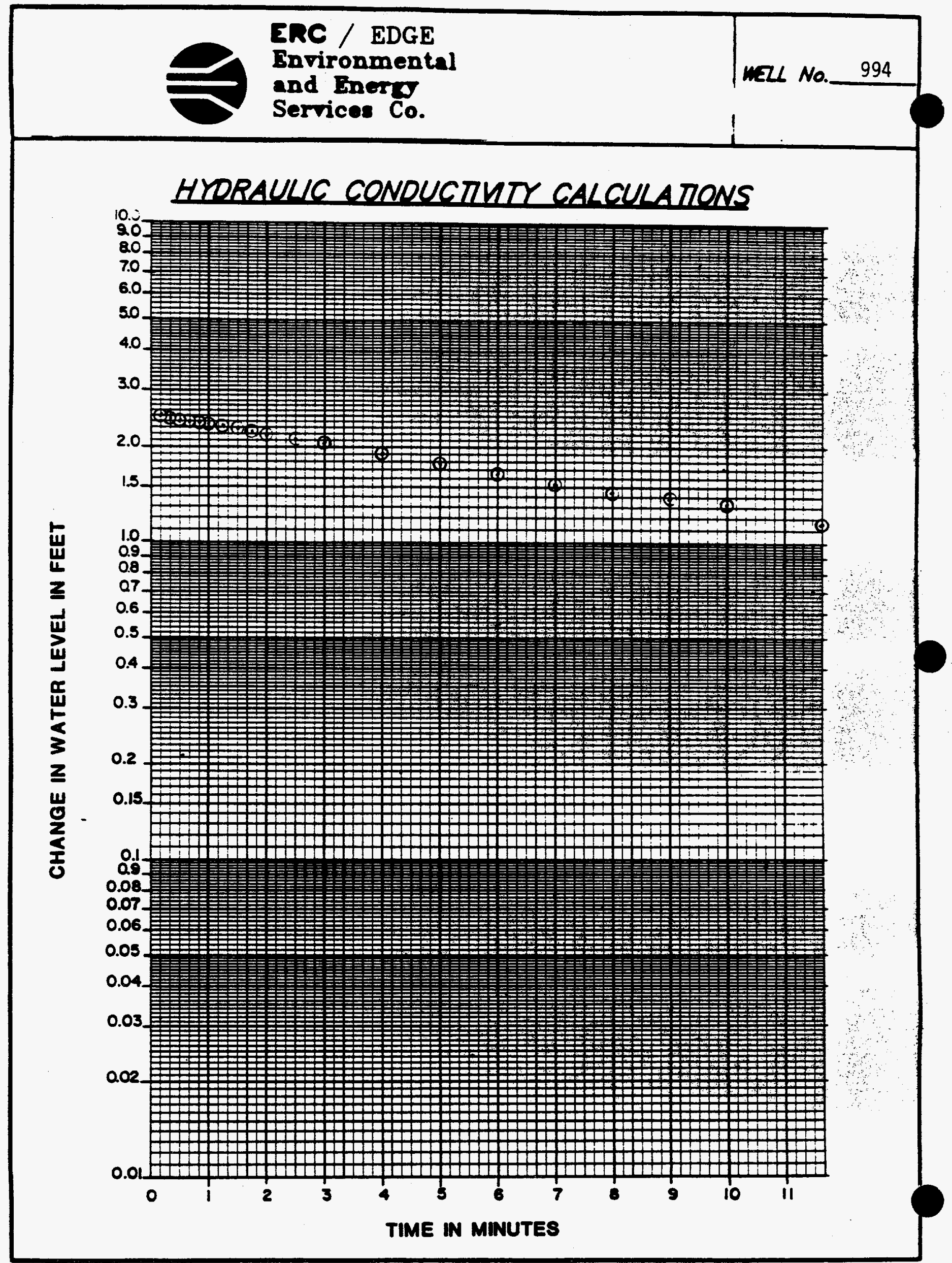

PAC 18 of 19 


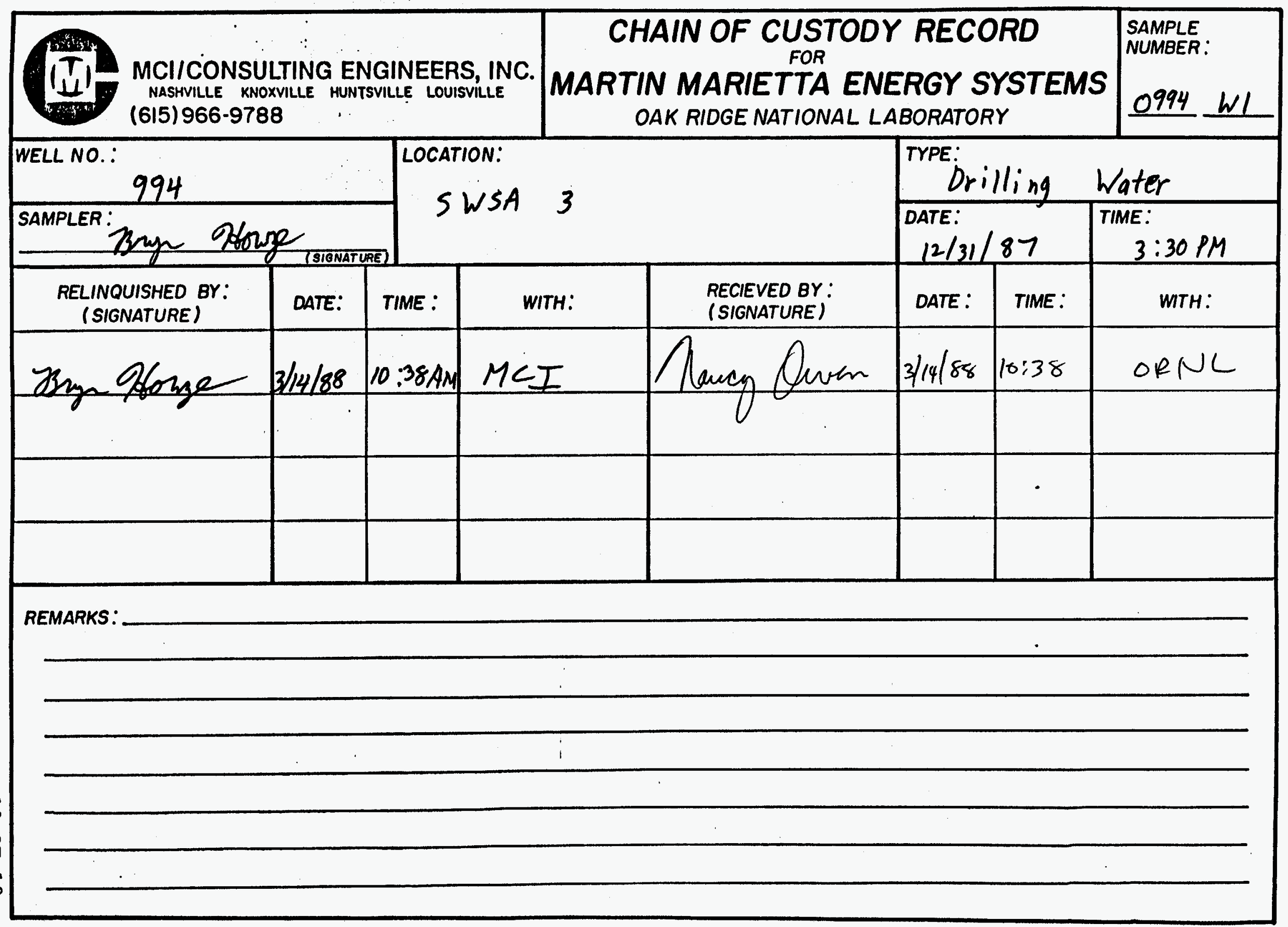


ERC / EDGE

Environmental

and Energy

Services Co.

\subsection{General Information}

\subsection{Tell Location}

Monitoring well number 995 is located in WAG 3 . It is approximately $100^{\prime}$ east of the northwest corner of SWSA 3. The location is shown on ORNL drawing number C3E20004 A075. Survey coordinates for this well are N 22,011.4058, E 25,867.5608 (X-10 grid) or latitude $35^{\circ}-55^{\prime}-07.23^{\prime \prime}$ and longitude $84^{\circ}-19^{\prime}-53.01^{\prime \prime}$. Coordinate data were provided by Martin Marietta Energy systems. The method used for conversion from X-10 grid to Tennessee-Lambert State Plane Coordinates came from the publication "Tennessee Valley Authority Data Services Branch and Mapping Services Branch, Oak Ridge, Tennessee, DOE Plant Control, November 6, 1985, Field Book: Ess-3115, pp. 1-20." The latitude and longitude were calculated by Adams Craft Herz Walker Engineering, Inc., using methods from the U.S. Coast and Geodetic Survey Publication 62-4, "State Plane Coordinates by Automatic Data Processing."

\subsection{Drilling Information}

Well number 995 was drilled by Geotek Engineering Company. An Ingersoll-Rand Air Rotary rig was used to drill this boring for monitor well installation under operation of Larry Ledbetter with the assistance of Fred Dixon. Drilling commenced on 11-28-89 and was finished on 12-5-89. Paragraph 2.4.1 includes a detailed discussion of the well installation and a well schematic is included on the well installation/ completion form. A synopsis of the drilling activity follows. This information was typed directly from 
field notes and was edited only when necessary for clarification.

11-28-89 The Ingersoll-Rand and equipment were decontaminated.

11-29-89 The rig and auger equipment were mobilized to the site, plastic was layed down and the equipment was set up. The borehole was split spooned and augered to 14.0'. A bulk density was taken from 4.4 to 4.8 '. Soil sample 995501 was taken from 9.0 to 10.3 . A 14.0-inch borehole was then augered to $7.0^{\prime}$ and a 10-inch diverter casing set.

11-30-89 The Ingersoll-Rand and equipment were decontaminated and mobilized to the site. A leak was found in the main hydraulic control line. Drilling activities ended until repair could be made.

12-1-89 The equipment was rigged up and an 8-inch bore hole was advanced to 20.0'. After the boring was cleaned, and after 35 minutes of recharge, no water was measured in the borehole. The boring was advanced to $30^{\prime}$, cleaned and after waiting for 30 minutes, no water was found. The boring was advanced to $42.5 \%$ cleaned and after waiting 15 minutes, no water was found. The boring was then advanced to a total depth of 48.5. An air and a water sample were taken.

12-4-89 After a meeting with Bill Mc Master, it was decided to check the water level then blow the borehole dry and check the water level 
ERC / EDGE

Environmental

and Energy

Services Co.

at 30 minutes and 1 hour, then drill further if necessary. The initial water level was at $21.0^{\prime}$. The borehole was then blown dry and after 30 minutes, the water level was at $42.5^{\prime}$. It was decided to set the well at this depth. Fifteen feet of screen and $35^{\prime}$ of casing was installed to a depth of $47.84^{\prime}$. The sand was tremied to $30.30^{\prime}$ and bentonite poured to $27.88^{\prime}$

12-5-89 The annulus was tremie grouted and covered with insulation to protect against freezing.

This well was logged by ERC Environmental and Energy Services Co., Inc., hydrogeologist C. Allison Bailey. All well construction materials and supplies were from Martin Marietta Energy Systems approved batches. The batch origin of individual items is shown on the included Monitoring Well Materials Certification form.

\subsection{Technical Information}

\subsection{Decontamination Procedures}

The drilling rig, down hole tools, surface casing, stainless steel screen, stainless steel casing, centralizers, and stainless steel silt trap underwent the cleaning decontamination procedures outlined in the drilling specifications (Release specific Technical Directions for Regulatory Compliance Monitoring Wells Phase 1, Oak Ridge National 
Laboratory, Oak Ridge, w.0. K-4147, April 1987, pgs. 2-4). A checklist of the cleaned materials is included with this data package.

\subsection{Geology}

WAG 3 is located in Melton Valley which is in the Valley and Ridge Physiographic Province of East Tennessee. WAG 3 is underlain by limestone, siltstone and shale of the Middle Ordovician Chickamauga Group. The Chickamauga Group consists of eight units, designated by letters "A" to "H" (Stockdale, 1951). WAG 3 is underlain by units $E, F, G$ and $H$. These units consist of thin bedded nodular limestone with clay and shale partings. A portion of unit $H$ and unit F consists of calcareous siltstone alternating with beds of olive gray to maroon shale. Strike and dip varies from $\mathrm{N} 45^{\circ} \mathrm{E}$ to $\mathrm{N} 55^{\circ} \mathrm{E}$ and $25^{\circ}$ to $35^{\circ}$ southeast, respectively.

\subsection{Sample Collection}

Two samples were collected during drilling, placed in I-CHEM specialty cleaned glass containers, sealed and submitted to Sample Receiving, Analytical Chemistry Division, Bldg. 4500S, ORNL. Chain of custody forms for these samples are included with this data package. Soil sample 995501 was collected in the split spoon interval from 9.0 to 10.3 on $11-29-89$.

A drill water sample was collected from the water pump on the drill rig on 12-1-89. Analytical results for the soil and drill water samples described above can 
be obtained from the Remedial Action Program data base at ORNL.

A bulk density soil sample was collected from the split spoon sample interval from 4.4 to 4.8 . The sample was measured and weighed, and a bulk density of 1.82 grams $/ \mathrm{cm}^{3}$ was calculated.

The Ingersoll-Rand T-4's compressed air was sampled with a cloth filter inserted between drill rods on 12-1-89. The sample was examined with an ultraviolet light for the presence of hydrocarbons. The filter showed no evidence of hydrocarbons.

\subsection{Installation and Development}

\subsubsection{Installation}

This was a "Type D" well. A 6-inch diameter boring was split spooned and augered from ground surface to auger refusal (14.0 feet). The air rotary method was required to complete the boring to the specified total well depth. Therefore, a 14.0- inch diameter boring was augered from ground surface to 7.0 feet and a 10.0-inch diverter casing was installed and grouted. An 8-inch diameter boring was then drilled with an air rotary tricone roller bit from 7.0 to 48.5 feet. A 2inch diameter stainless steel screen with welded bottom cap was installed from 47.84 to 32.84 feet. A 2-inch diameter stainless steel casing was installed above the screen at 32.84 feet and extended 1.65 feet above ground surface. A sandpack was then tremied into the annular space from 47.84 to 30.30 feet, with 
ERC / EDGE

Environmental

and Energy

Services Co.

a 2.42-foot bentonite pellet seal poured into the annular space above the sandpack from 30.30 to 27.88 feet. The annular space from the top of the bentonite seal to the surface was tremie-grouted with a cement/bentonite slurry. A detail of the well is included on the well installation/completion form.

\subsubsection{We11 Development}

Well number 995 was developed to remove drill cuttings, silt, and other fines. The monitoring well was developed using a Geoguard pump with an air compressor. All pumps were cleaned prior to use according to specified cleaning procedures (see Paragraph 2.1). The well was developed until a measured total of 203 gallons of water had been evacuated and the clarity of the discharge water was approved by the company representative. The final turbidity value measured at completion was 2.0 NTU's. A development form showing the exact method of development and other pertinent data is appended.

\subsubsection{Installation of Dedicated Monitoring well Pump}

After the well was developed, a Geoguard Model No. 5614 dedicated monitoring well pump was installed on 5-8-90 at a depth of 45.7 feet below ground surface. These pumps are decontaminated at American sigma and are sent prepackaged. A copy of the pump certification is kept on file at ORNL. 


\subsection{Hydraulic Conductivity Testing}

Well number 995 was tested for the determination of hydraulic conductivity of the aquifer in the vicinity of the well screen. This was accomplished by instantaneously adding a known quantity of water to the monitoring well and measuring the recovery of the water level over time. The changing water levels were measured using a Druck 15 psig pressure transducer and an omnidata Datapod II data. recorder. The hydraulic conductivity value of $3.94 \times 10^{-6} \mathrm{~cm} /$ second (shown as permeability on the hydraulic conductivity calculations printout attached) was calculated using the Bouwer and Rice method. A computer printout of the hydraulic conductivity calculations is included in this data package. 


\section{PRE-DRILLING CHECKLIST FOR MONITORING WELLS}

RRE-DRILLING TASKS

1. EXCAVTION PERMIT OBTAINEO

2. ALL EQUIPMENT HAS BEEN CLEANED BEFORE DRILLNG.

30. SCREEN AND CASING HAVE BEEN WASHED, STEAMED, RINSED WTH DE-IONIZED OR DISTLLED WATER, RINSED WTH ISOPROPY ALCOHOL, WRAPPED WTH PROTECTVE COVERING AND STORED OFF THE GROUND.

36. PRE-PACKAGED SCREENS, CASING AND CENTRALIZERS WERE USED.

4. WORK AREA FOR SAMPLE EXAMINATION COVERED WTH CLEAN POL YETHRENE.

5. CLEAN KNIVES, GLOVES, SAMPLE JARS AND LABELS ON HAND.

6. POL YETHRENE COVER IN PLACE OVER HOLE.

7. AIR ROTARY COMPRESSED AIR SAMPLED.

COMPLIANCE

\begin{tabular}{|c|c|}
\hline$\frac{0 A \pi E}{11-28-89}$ & $\frac{\text { WIIALS }}{C A B}$ \\
\hline $11-28-89$ & $C A B$ \\
\hline$N / A$ & \\
\hline $12-04-89$ & $C A B$ \\
\hline $11-21-89$ & $C A B$ \\
\hline $11-29-89$ & $\triangle A B$ \\
\hline $11-29-89$ & $C A B$ \\
\hline $12-04-89$ & $C A B$ \\
\hline
\end{tabular}

RESULTS: No hydrocarbons detected under ultraviolet light.

ADOIMONAL NOTES/OBSERVATIONS:

OBSERVER SIGNATURE DATE $\frac{\mathrm{C} \text {. CoDeduDral } 12-04-89}{\text { c. Altison Bailey }}$ 


\section{DECONTAMINATION CHECKLIST DRILLING EQUIPMENT}

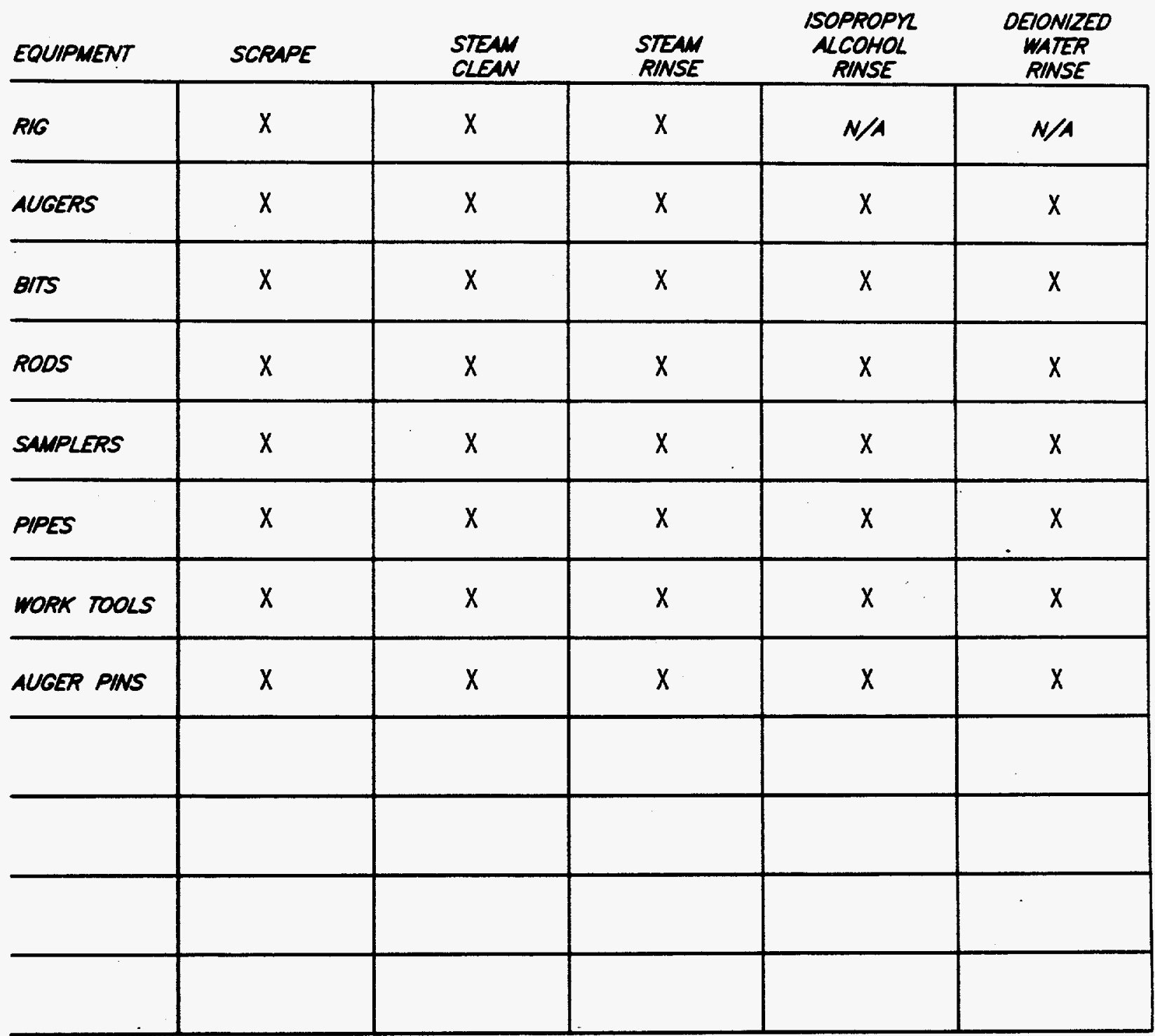

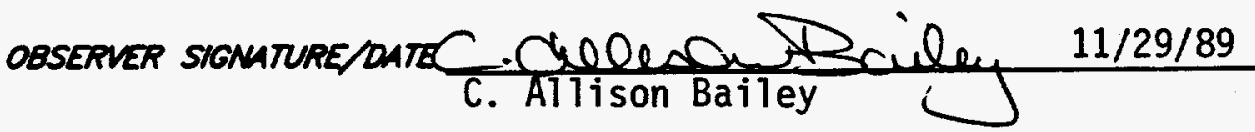




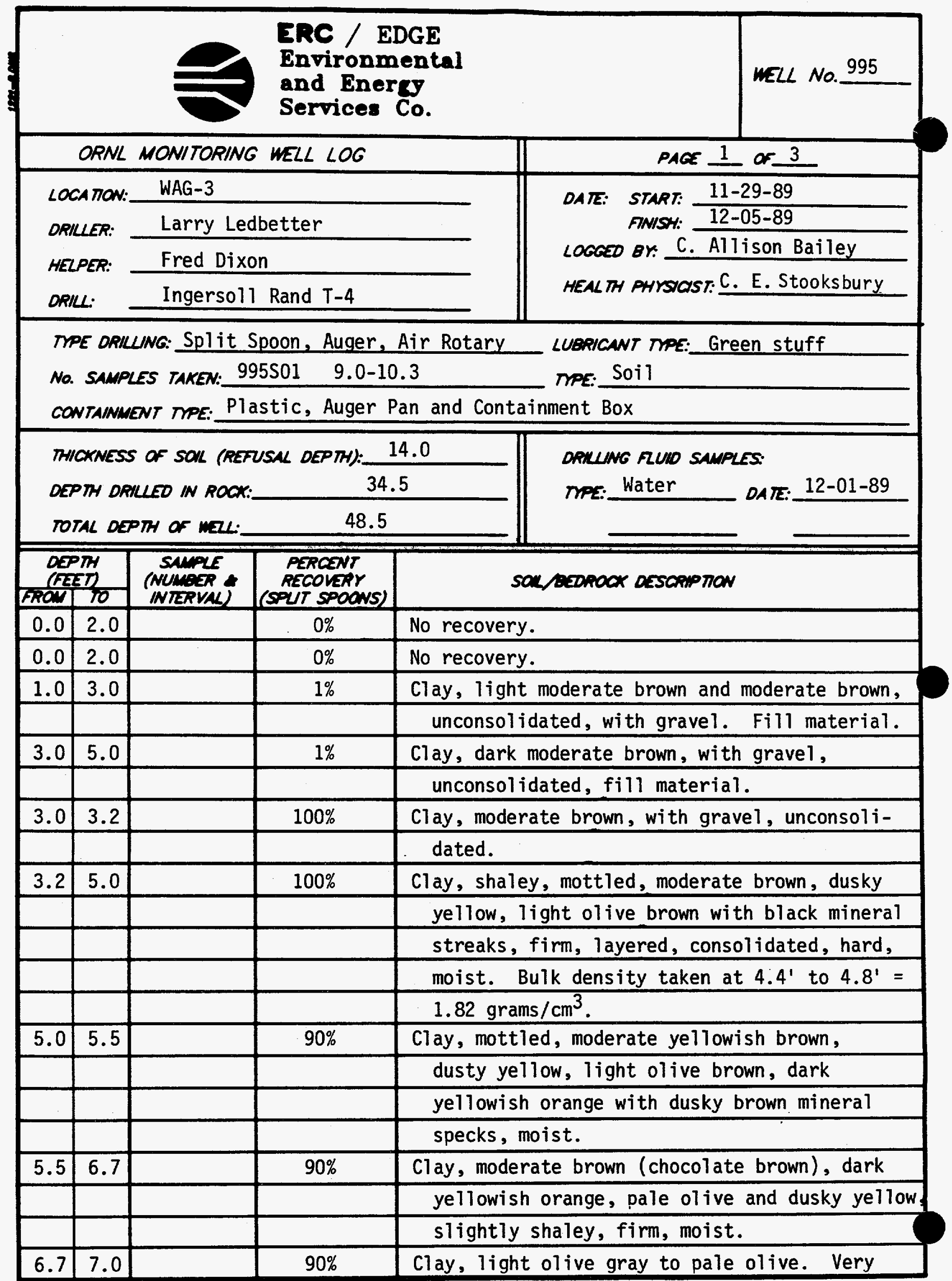




\begin{tabular}{|c|c|c|c|c|}
\hline 47də0 Le701 & & & $G \cdot 8 t$ & \\
\hline -6u!LLL LAP MOLS 'pueH & & & $0^{\circ} 8 t$ & 0.02 \\
\hline "Mols 'bu!LL!dp delnbədd! 'y6nod 'pdeH & & & $0^{\circ} 02$ & $S^{*} 9 \mathrm{I}$ \\
\hline 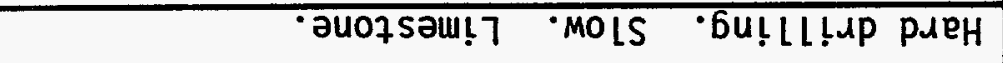 & & & $\mathrm{G}^{\cdot 9 \mathrm{I}}$ & $G^{\circ} \mathrm{SI}$ \\
\hline •7set 'bu!LL!ap pueH* & & & $G^{\cdot} \mathrm{SI}$ & $0^{\circ} \mathrm{t} \mathrm{I}$ \\
\hline •7s!ow'แ4!f & & & & \\
\hline 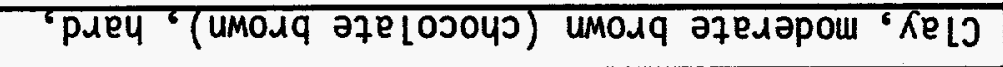 & $\% 00 I$ & & $0^{\circ}+\tau$ & $9^{\circ} \varepsilon I$ \\
\hline 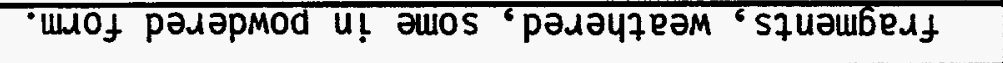 & & & & \\
\hline әрлеL ' & $\% 00 \mathrm{I}$ & & $9^{\circ} \varepsilon I$ & $Z^{\bullet} \varepsilon I$ \\
\hline 75 !OW 'ple4 KL746!Ls & & & & \\
\hline 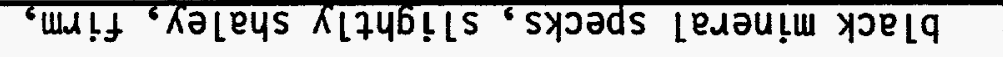 & & & & \\
\hline 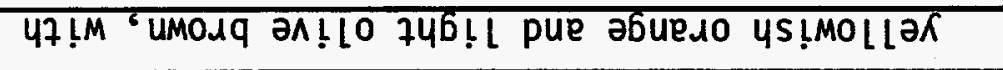 & & & & \\
\hline 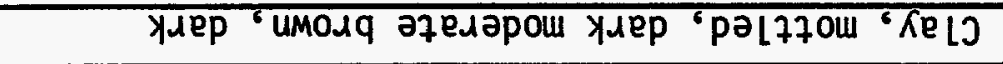 & $\% 00 T$ & & $Z^{\cdot \varepsilon I}$ & $0 \cdot 2 \mathrm{I}$ \\
\hline 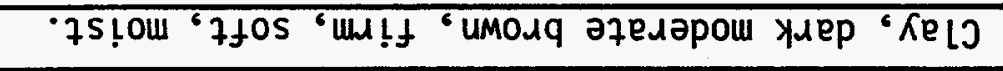 & $\% 0[$ & & $0 \cdot 2 \mathrm{I}$ & $\varepsilon^{\circ} 0 \mathrm{I}$ \\
\hline 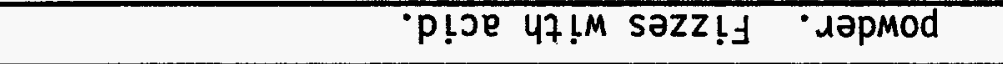 & & & & \\
\hline 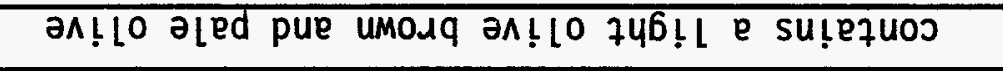 & & & & \\
\hline 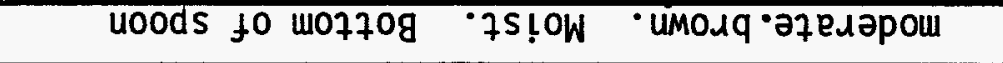 & & & & \\
\hline 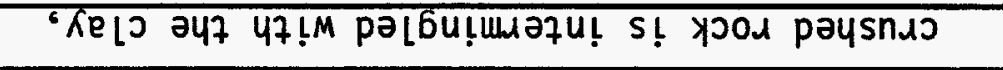 & & & & \\
\hline 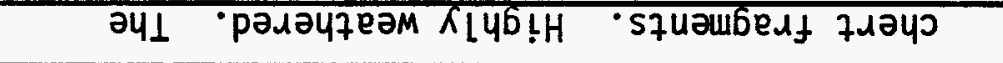 & & & & \\
\hline pue 'solo!7ued $\partial z ! s$ pues $47 ! M$ (prysnis) & & & & \\
\hline 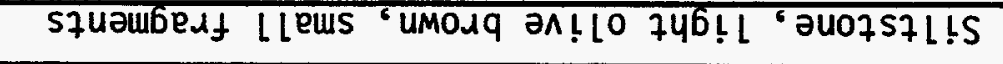 & $\% 00 \mathrm{I}$ & & $\varepsilon^{\circ} 0 \tau$ & $0^{\circ} 0 \mathrm{I}$ \\
\hline •7s!ou 'o!7seld pue puey & & & & \\
\hline 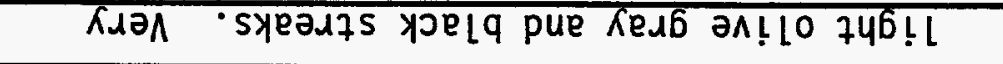 & & $\varepsilon^{\circ} 0 \mathrm{I}-0^{\circ} 6$ & & \\
\hline 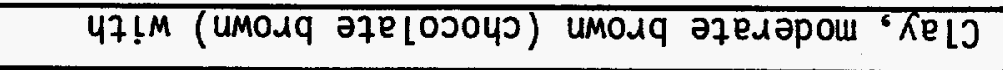 & $\% 00 \tau$ & IOSS66 & $0^{\circ} 0 \mathrm{~T}$ & 0.6 \\
\hline $.99^{\circ} \mathrm{L}$ & & & & \\
\hline 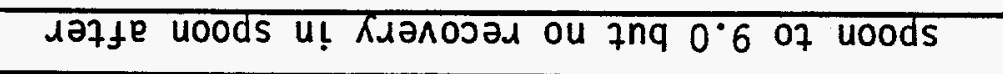 & & & & \\
\hline 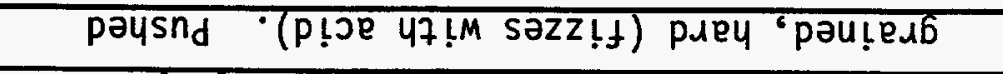 & & & & \\
\hline 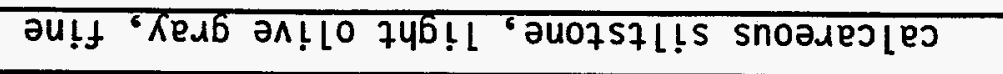 & & & & \\
\hline 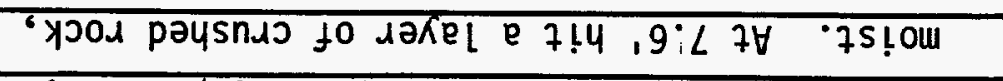 & & & & \\
\hline 'J!fseld 'ul!f 'pueH 'słezufs mollaK KXssnp & & & & \\
\hline 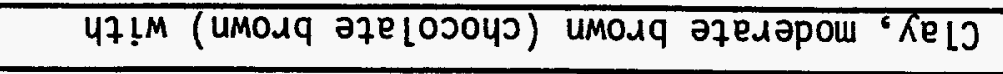 & $\% 0 \varepsilon$ & & 0.6 & $\overline{0} \cdot \mathrm{L}$ \\
\hline 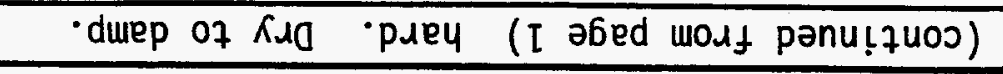 & & & $0 \cdot L$ & $L 99$ \\
\hline NoL Cl10530 ×004038/70s & $\begin{array}{c}(5 N 000151 / 725) \\
14310038 \\
1 N 30238\end{array}$ & $\begin{array}{l}\text { (7VA\&Z1N } \\
\text { o dBgWRN) } \\
\text { g7dWWS }\end{array}$ & $\frac{01}{113}$ & $\frac{102 y}{17-1)}$ \\
\hline$\varepsilon>0 \overline{2}$ sovd & $207773 n$ & DNISOLINON & $7 N \$ O$ & \\
\hline $\begin{array}{r}.05 \\
\qquad 0 \\
\text { T40 } \\
\text { जDO }\end{array}$ & $\begin{array}{l}\text { Bootaios } \\
\text { Ioug pus } \\
\text { muoxung } \\
\text { d / OVI }\end{array}$ & & & \\
\hline
\end{tabular}




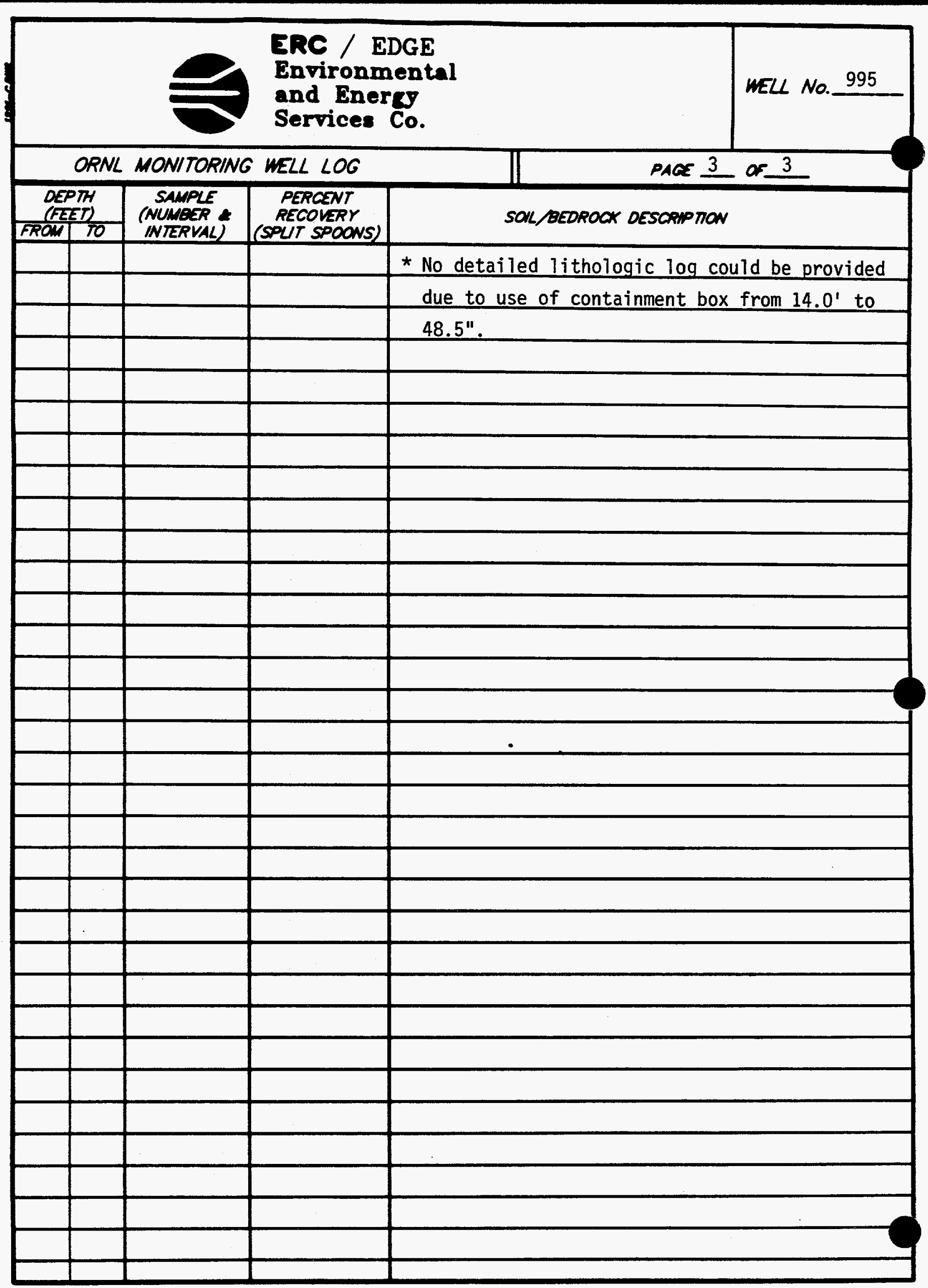




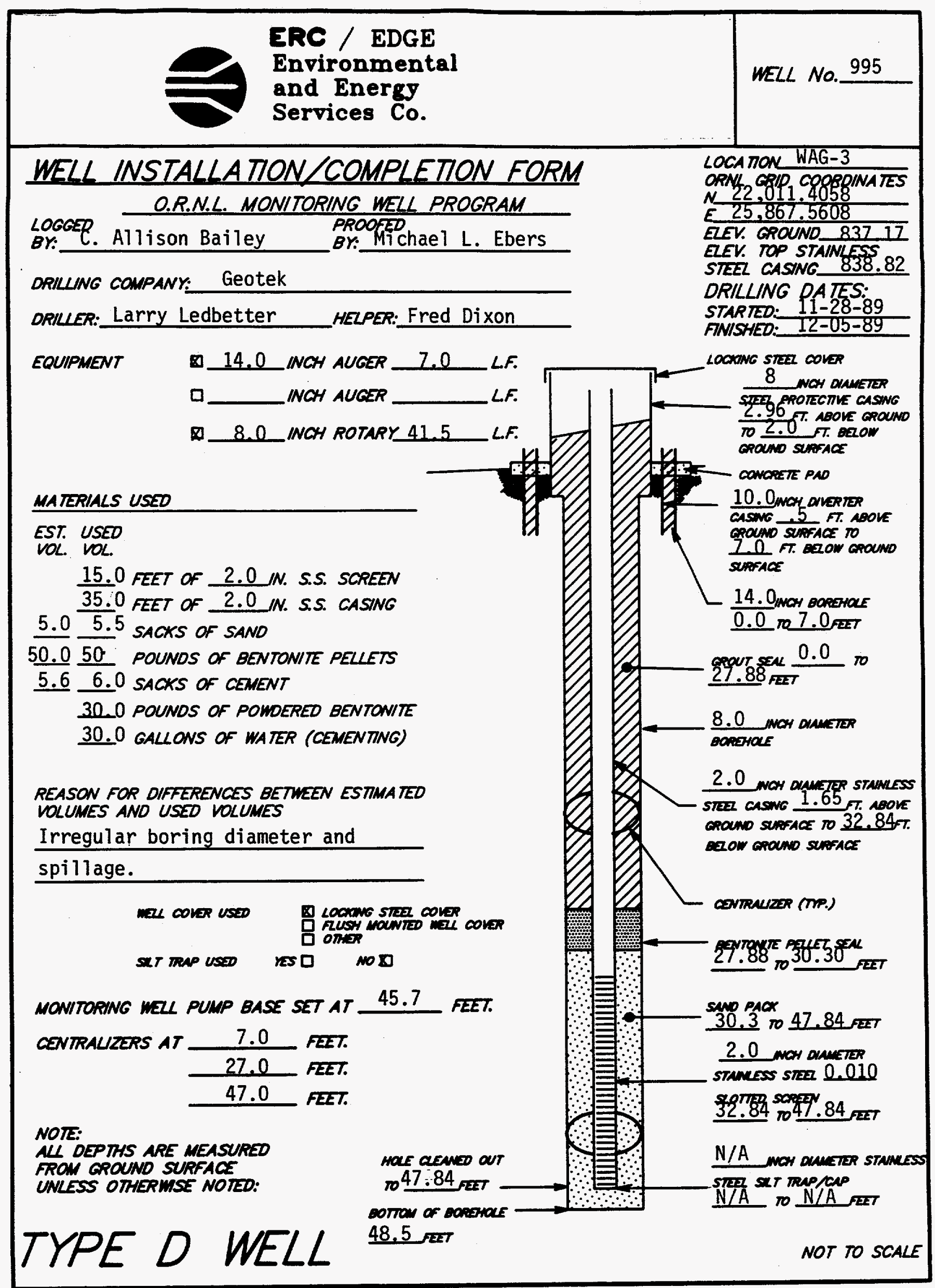

PAGE 13 of 22. 


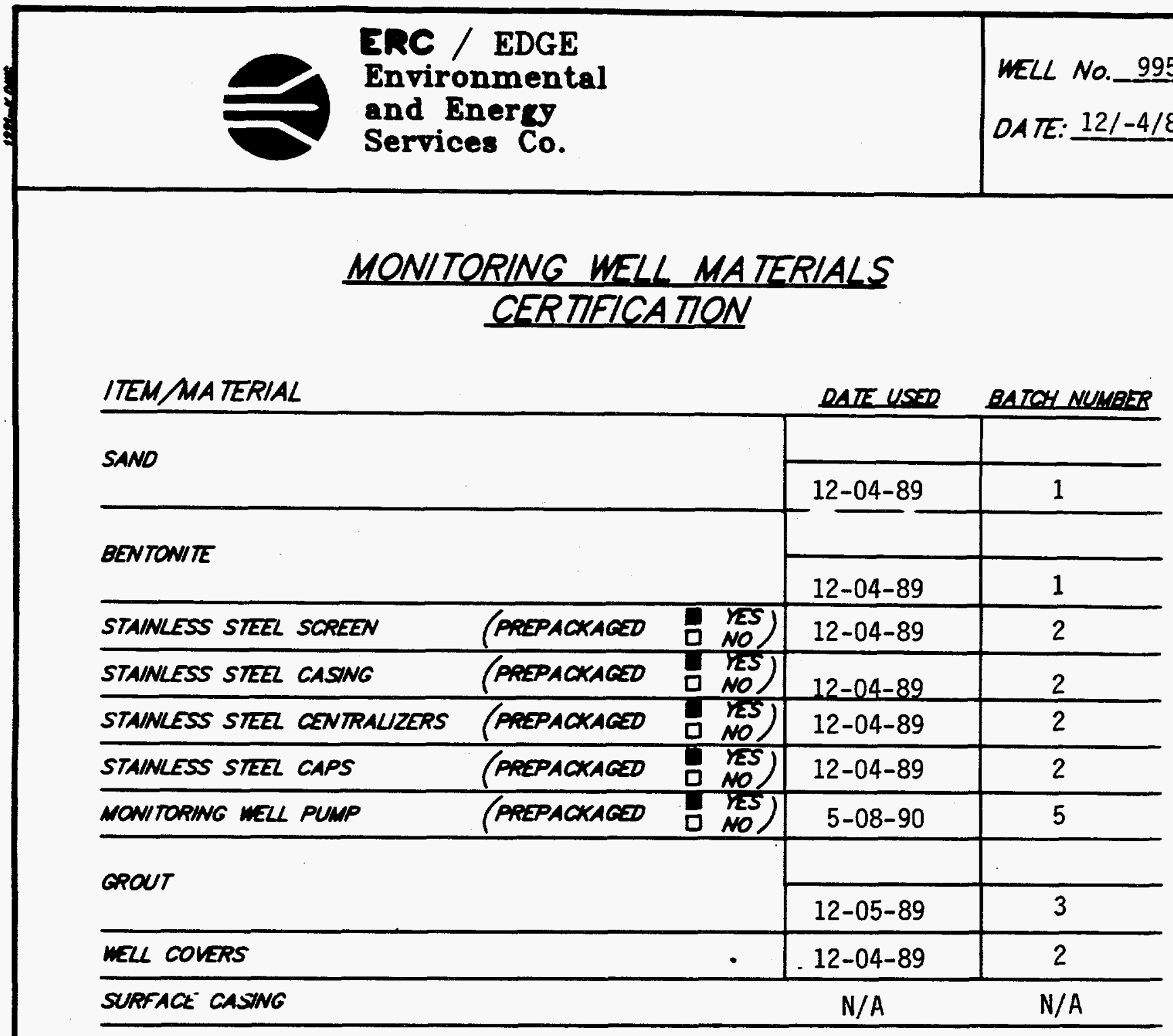

COMMENTS:

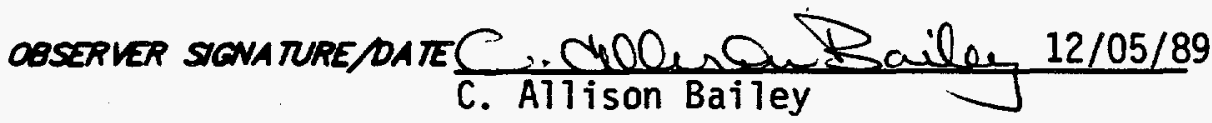

PACE 14 of 22 


\section{POST-MELL COMPLETION CHECKLIST}

\section{POST-WELL COMPLETON TASKS}

COMPLIANCE

\section{DATE INITALSS}

1. WUD SCRAPED FROM AUGERS, SMMPLERS, ANO ALL

$11-29-89$

$C A B$ OTHER EQUIPMENT.

2. ALL WUD FROM RIG AND EQUIPMENT SCRAPINGS AND CUTTINOS DISPOSED OF IN ACCORDANCE WTH THE SPECAFCA HON PROVDED.

3. WEL DEVEZOPED IN ACCOROANCE WTH THE SPECAFCA TON PROVOED AND DETAKS OF THE DEVELOPNENT ACTVTY RECORDED.

4. DRHLNG SITE PROPERLY CLEANED UP AFTER COMPLETION OF MELL MSTALLATON.

11-29-89 $\subset$ CAB $5-08-90$

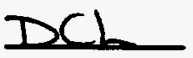

$12-04-89$

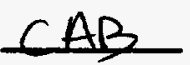

- RELEASE SPECIFC TECANCAL DIRECTONS FOR REQULATORY COMPUANCE MONITORING WELLS PHASE I, OAK RHDGE NATIONAL LABORATORY, OAK RIDGE, W.O. K-4147. APRLL 1987.

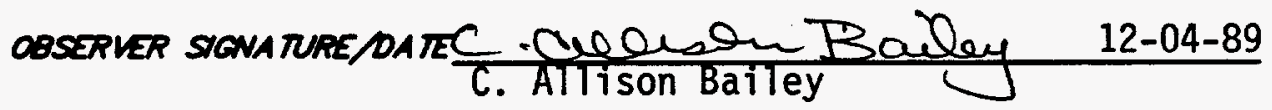

$$
\begin{aligned}
& \text { D. Chanles Putle 5-08-90 } \\
& \text { D. Charles Lyt Pe }
\end{aligned}
$$




\section{MONITORING WELL DEVELOPMENT FORM}

DEVELOPMENT DETAILS

METHOD OF

DEVELOPMENT: Surging and Pumping

DEVELOPMENT

BEGAN OATE:

$5 / 03 / 90$

TME:

DEVELOPMENT

ENOING DATE:

$5 / 08 / 90$

OEVELOPMENT

OBSERVED BY.

D. Charles Lytle

ONE WELL VOLUME: 10.8 GALLONS

TOTAL GALLONS PUMPED: 203

TOTAL WELL VOLUMES PUMPED: 19.0

INITAL PH: 8.0 FINAL PH: 7.7

INITAL CONDUCTUTY (KS/cm): 635 FNAL CONDUCTUTY $(\mu S / \mathrm{cm}): 699$

DESCRIPTION OF INITAL TURBIDITY. Milky

DESCRIPTION OF FINAL TURBIDITY: Clear

FINAL MEASURED RURBIDITY: 2.0 NTU'S

WELL APPROVED BY: R. C. Williams MMES

\begin{tabular}{|c|c|c|}
\hline $\begin{array}{l}\text { ODOR } \\
\text { OF MATER: }\end{array}$ & None & \\
\hline $\begin{array}{l}\text { WATER } \\
\text { DISCHARGED } \\
\text { TO: }\end{array}$ & $\begin{array}{l}\text { 界 GROUNO SURFACE } \\
\text { D STORM SEWERS } \\
\text { D DRUNS }\end{array}$ & $\begin{array}{l}\text { ㅁ TANK IRUCK } \\
\text { D STORAGE TANKS } \\
\text { OTHER }\end{array}$ \\
\hline
\end{tabular}

INITAL PRE-DEVELOPMENT

WA TER DEPTH:

21.5 feet from around surface:-

DEVELOPMENT OBSERVATIONS 


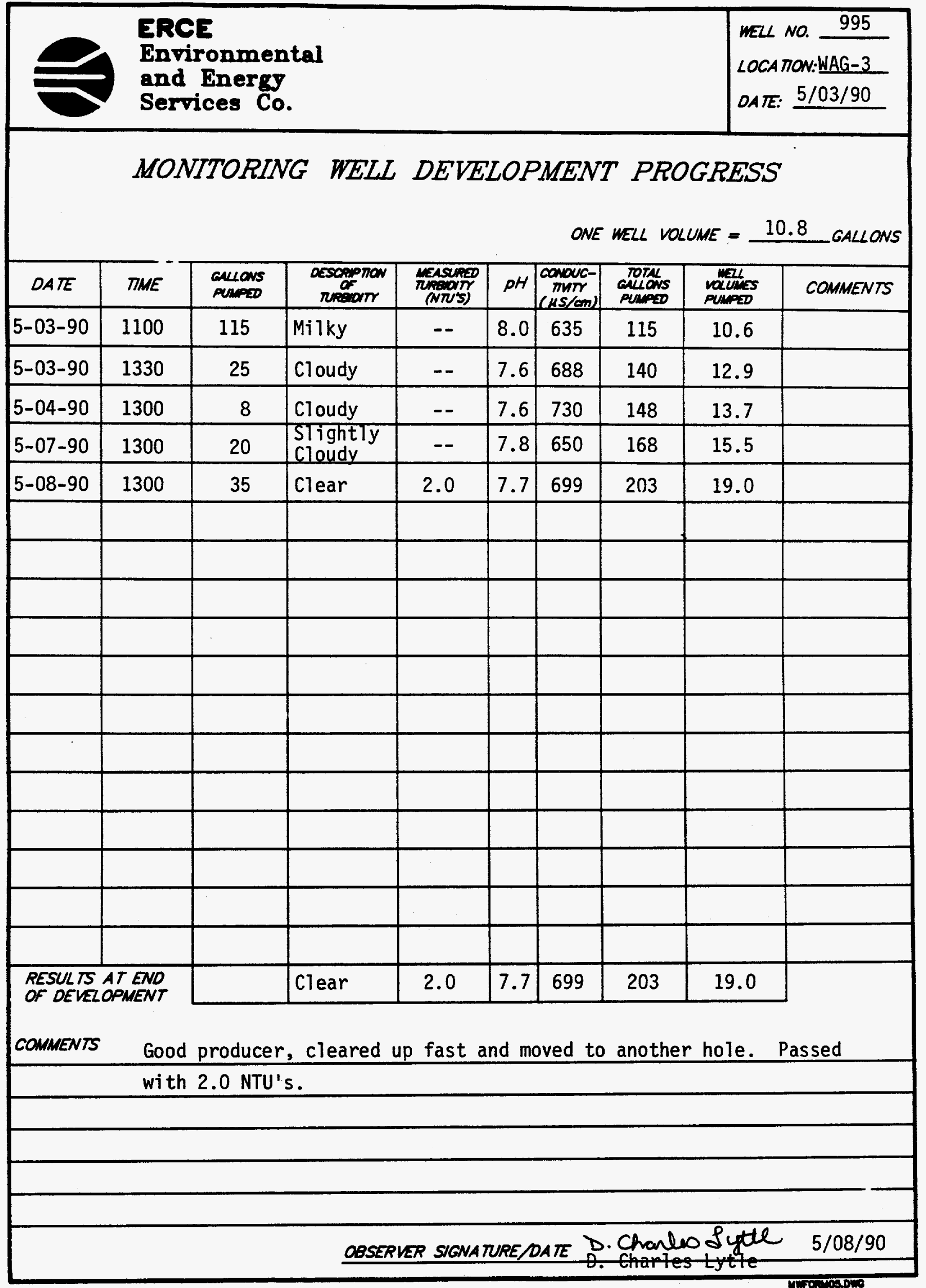




\section{HYDRAULIC CONDUCTIVTY CALCULATIONS}

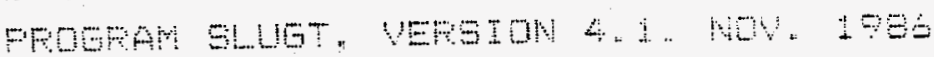

THIS FROGFAM CALULATES MEAN TRANGMISEIVITES FEM

SLUE-TEST DATA EASED ON TWO ANALYTIAL PPFOACHES:

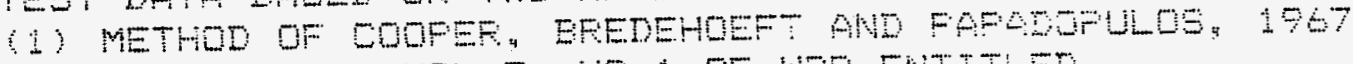
IAFT TCLE TN VOL \& NO \& OF WFE ENTTLLE

"RESFONSE OF A FINITE DIAHETEF HELL TO AN TMETANTANEOUS CHAFGE OF WATEF"'

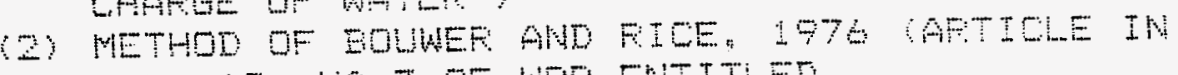

VOL. 12, NO. OF WFE ENTITLED

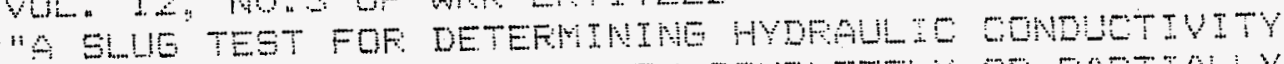

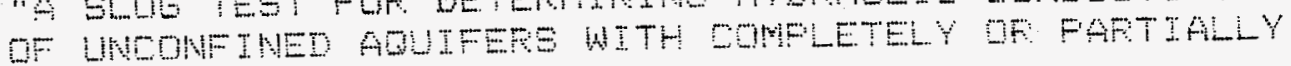

PENETSATINE WELLS"

WELL NO: :95:

DATE OF TEST: $5 / 16 / 90$

PEDECT NO : E221-601

CLIENT \#NES

BITE LOCATION: $\times 10$

EDEE, INC. FIELD IMVETTEATORA DEUCE MEMATEF

INPUT DATA ARE:

INNEF CASTNE DIAMETEP $=2.00$ INCHES

INNEF SCFEEN DF OFEN-HOLE DTAMETEF = 2.00 INCHES

DIAMETEF OF DETLLED HOLE $=9.63$ INCHES

LENGTH OF SCFEEN OF INTAKE FORTION = 15.00 FEET

DEFTH FFOM STATIC LEVEL TO EOTTOM OF SCFEEN $=24.10$ FEET

THICHNES OF SATUFATED AOUIFEF ZONE = 4.00 FEET

DEFTH TO STATIC WATEF LEVEL EELOW FEF. FOTNT = "76 FEET

ESTIMATED FONOEITY OF GRAVEL FACE = .3O

FALLINE-HEAD INDEX $=1$ " 1 "IF FALLTNE "O" TF RISINE)

NUMBEF OF DEFTH-TIME DATA FOINTS $=3$

HO WAS COMFUTED FFOM INTEFCEFT UF FLOT OF LOG IH) VS. TIME

SUECESETUE COMFUTED

VALUEE FOF: HO

(FEET)

4. 2315

4.236 


\section{HYORAULIC CONDUCTIVTY CALCULATIONS}

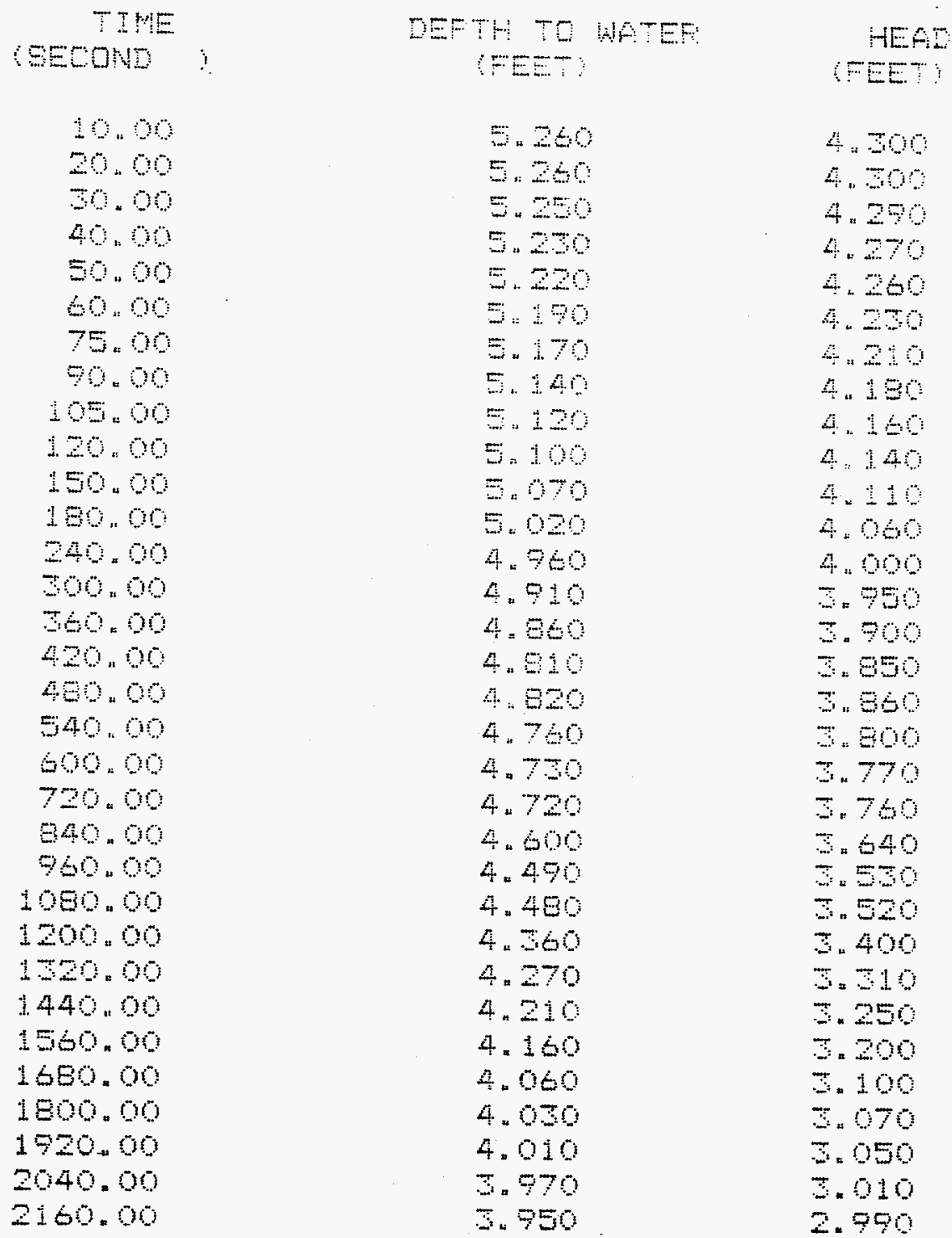

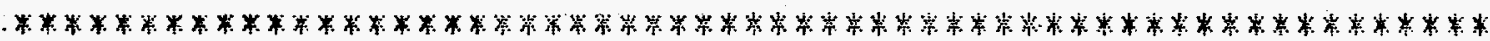

METHOD OF BOUWEE AND FISE

COMFUTED FESULTS USING DIAMETEF OF DFILLED HOLE:

FERMEAEILITY $=1.29 E-07 \mathrm{FT} / S E C O N D=3.94 E-06$ CM/SEE

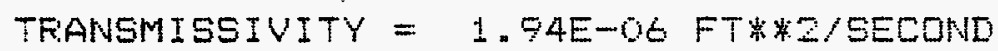




\section{ERC / EDGE Bnvironmental and Bnery Services Co.}

\section{HYORAULIC CONDUCTUTY CALCULATONS}

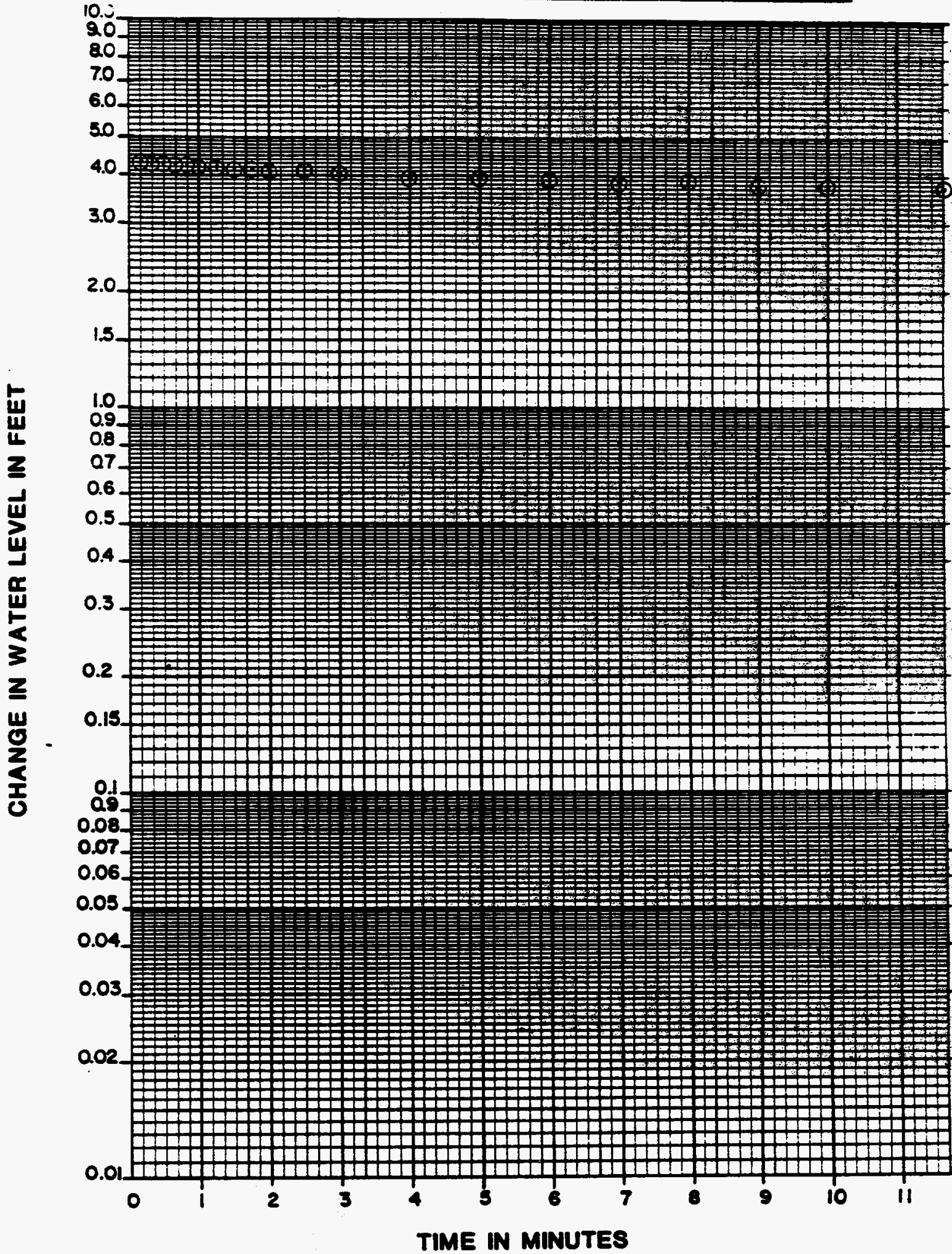




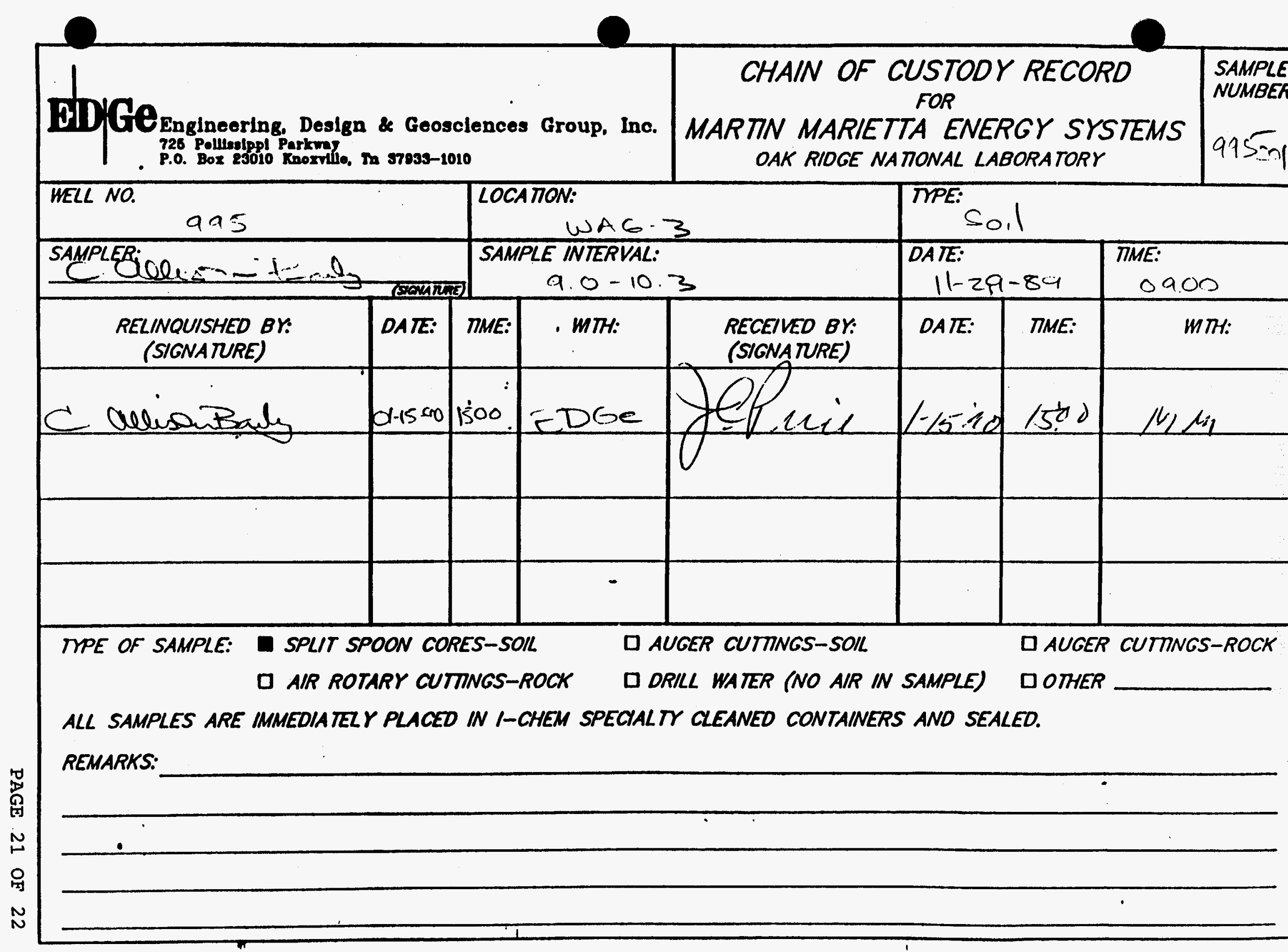


General Information

\subsection{Nell Location}

Monitoring well number 996 is located in WAG 3 . It is along the north perimeter fence of SWSA 3 . The location is shown on ORNL drawing number C3E20004 A075. Survey coordinates for this well are N 21,920.1708, E 26,458.1823 (X-10 grid) or latitude $35^{\circ}-55^{\prime}-09.73^{\prime \prime}$ and longitude $84^{\circ}-19^{\prime}-46.43^{\prime \prime}$. Coordinate data were provided by Martin Marietta Energy systems. The method used for conversion from X-10 grid to Tennessee-Lambert state Plane coordinates came from the publication "Tennessee Valley Authority Data Services Branch and Mapping Services Branch, Oak Ridge, Tennessee, DOE Plant Control, November 6, 1985 , Field Book: ESS-3115, pp. 1-20." The latitude and longitude were calculated by Adams Craft Herz Walker Engineering, Inc., using methods from the U.S. Coast and Geodetic survey Publication 62-4, "State Plane Coordinates by Automatic Data Processing."

\subsection{Driling Information}

Well number 996 was drilled by Geotek Engineering Company. An Ingersoll-Rand T-4 Air Rotary rig was used to drill this boring for monitor well installation under operation of Larry Ledbetter with the assistance of Fred Dixon. Drilling commenced on 11-16-89 and was finished on 11-28-89. Paragraph 2.4.1 includes a detailed discussion of the well installation and a well schematic is included on the well installation/completion form. A synopsis of the 


\begin{tabular}{|c|c|}
\hline & $\begin{array}{l}\text { ERC / EDGE } \\
\text { Environmental } \\
\text { and Energy } \\
\text { Services Co. }\end{array}$ \\
\hline $\begin{array}{l}\text { drilling a } \\
\text { directly } \\
\text { necessary } \\
11-16-89\end{array}$ & $\begin{array}{l}\text { ctivity follows. This information was typed } \\
\text { from field notes and was edited only when } \\
\text { for clarification. } \\
\text { The Ingersoll-Rand and equipment were set } \\
\text { up. (The rig was moved over from well \#997 } \\
\text { and there was no need to decontaminate the } \\
\text { rig). The augers and down hole tools were } \\
\text { decontaminated. A } 22.0 \text { " boring was augered } \\
\text { to } 7.0 \text { ' and a } 15 \text { 1/4 diverter casing was } \\
\text { installed and grouted. } \\
\text { The Ingersoll-Rand and tools were } \\
\text { decontaminated and mobilized to the site. } \\
\text { Plastic was layed down and the equipment } \\
\text { unloaded. The rig was set-up along with } \\
\text { the containment box and diverter head. A } \\
\text { 14.0' borehole was advanced to } 32.5 \text { '. } \\
\text { An alcohol type odor was noticed when } \\
\text { drilling began but quickly dissipated. The } \\
\text { boring was advanced to } 36.0 \text { ' and a } 103 / 4 " \\
\text { surface casing was installed to a depth of } \\
35.70 \text {. A bentonite seal was poured to } \\
34.75 \text { '. The annulus was tremie grouted to } \\
\text { the surface; while grouting the borehole, } \\
\text { an alcohol type odor was again noticed. } \\
\text { Jill Greene was notified and an Industrial } \\
\text { Hygenist was sent to the site with an } \\
\text { organic vapor Analyzer. No readings were } \\
\text { detected at the well site or in the } \\
\text { containment boxes. } \\
\text { An } 8-i n c h \text { borehole was drilled with a } \\
\text { tricone bit to } 48.0 \text { '. After a } 1 \text { hour } \\
\text { recharge, } 18 \text { feet of water was measured. }\end{array}$ \\
\hline
\end{tabular}


ERC / EDGE

Environmental

and Energy

Services Co.

The borehole was cleaned and the water level checked again. A recharge of $1 \mathrm{ft} / 3$ minutes was calculated. The boring was advanced to a total depth of 62.5'. An air and a water sample were taken. The 4-inch stainless steel screen and casing were installed to a total depth of 61.76'. Sand was tremied to $38.96^{\prime}$ and bentonite poured to $35.75^{\prime}$.

11-28-89 The annulus was tremie grouted with 9 bags of cement and 58 bentonite.

This well was logged by ERC Environmental and Energy Services Co., Inc., hydrogeologist c. Allison Bailey. All well construction materials and supplies were from Martin Marietta Energy Systems approved batches. The batch origin of individual items is shown on the included Monitoring Well Materials Certification form.

\subsection{Technical Information}

\subsection{Decontamination Procedures}

The arilling rig, down hole tools, surface casing, stainless steel screen, stainless steel casing, centralizers, and stainless steel silt trap underwent the cleaning decontamination procedures outlined in the drilling specifications (Release specific Technical Directions for Regulatory Compliance Monitoring Wells Phase 1, Oak Ridge National Laboratory, Oak Ridge, w.0. K-4147, April 1987, pgs. 2-4). A checklist of the cleaned materials is included with this data package. 


\subsection{Geology}

WAG 3 is located in Melton Valley which is in the Valley and Ridge Physiographic Province of East Tennessee. WAG 3 is underlain by limestone, siltstone and shale of the Middle Ordovician Chickamauga Group. The Chickamauga Group consists of eight units, designated by letters "A" to "H" (Stockdale, 1951). WAG 3 is underlain by units $E, F, G$ and $H$. These units consist of thin bedded nodular limestone with clay and shale partings. A portion of unit $H$ and unit F consists of calcareous siltstone alternating with beds of olive gray to maroon shale. strike and dip varies from $\mathrm{N} 45^{\circ} \mathrm{E}$ to $\mathrm{N} 55^{\circ} \mathrm{E}$ and $25^{\circ}$ to $35^{\circ}$ southeast, respectively.

\subsection{Bample Collection}

One sample was collected during drilling, placed in an I-CHEM specialty cleaned glass container, sealed and submitted to Sample Receiving, Analytical Chemistry Division, Bldg. 4500s, ORNL. A chain of custody form for this sample is included with this data package.

A drill water sample was collected from the water pump on the drill rig on 11-27-89. Analytical results for the sample 996 W01 described above can be obtained from the Remedial Action Program data base at ORNL.

The Ingersoll-Rand Air Rotary's compressed air was sampled with a cloth filter inserted between drill rods on 11-27-89. The sample was examined with an 
ERC / EDGE

Environmental

and Energy

Services Co.

ultraviolet light for the presence of hydrocarbons. The filter indicated no evidence of hydrocarbons.

\subsection{Installation and Development}

\subsubsection{Installation}

This was a "Type B" well. A 22.0-inch diameter boring was augered from ground surface to 7.0 feet. A 15 1/4-inch diverter casing was installed from surface to 7.0 feet below ground surface and grouted in place. The boring was then extended with a 14.5-inch air rotary tricone roller bit from 7.0 feet to 36.0 feet. A 10 3/4-inch diameter string of decontaminated steel surface casing was installed from 0.0 feet to 35.7 feet, sealed with a 1.25-foot bentonite pellet layer from 35.7 feet to 34.75 feet, and tremie grouted in place. The surface casing minimizes potential cross contamination between the regolith and bedrock water bearing zones. After the surface casing was installed, an 8-inch diameter boring was drilled to a total depth of 62.5 feet. A 4-inch diameter stainless steel screen with threaded bottom cap was installed from 61.76 feet to 41.13 feet. A 4-inch diameter stainless steel casing was installed from the top of the screen at 41.13 feet and extended 1.95 feet above ground surface. A sandpack was then tremied into the annular space from 61.76 to 38.96 feet, with a $3.21-$ foot bentonite pellet seal poured into the annular space above the sandpack from 38.96 to 35.75 feet. 


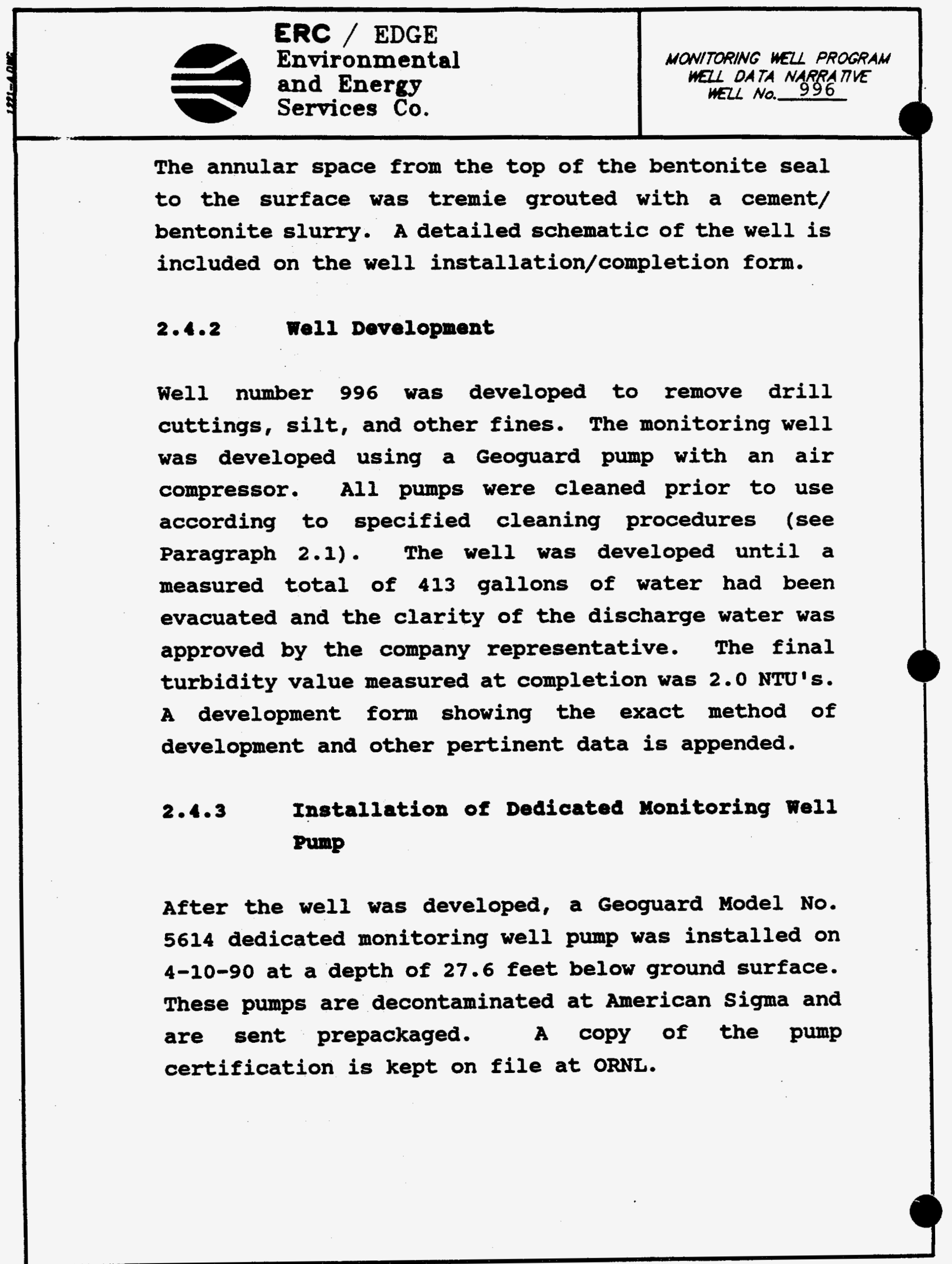




\subsection{Eydraulic Conductivity Testing}

Well number 996 was tested for the determination of hydraulic conductivity of the aquifer in the vicinity of the well screen. This was accomplished by instantaneously adding a known quantity of water to the monitoring well and measuring the recovery of the water level over time. The changing water levels were measured using a Druck 15 psig pressure transducer and an omnidata Datapod II data recorder. The hydraulic conductivity value of $6.46 \times 10^{-5} \mathrm{~cm} /$ second (shown as permeability on the hydraulic conductivity calculations printout attached) was calculated using the Bouwer and Rice method. A computer printout of the hydraulic conductivity calculations is included in this data package. 
ERC / EDGE

Environmental

and Enerey

WELL NO. 996

\section{PRE-DRILLING CHECKLIST FOR MONITORING WELLS}

PRE-DRILUNG TASKS

1. EXCAVTION PERMIT OBTAINED

2. ALL EQUIPMENT HAS BEEN CLEANED BEFORE DRILUNG.

30. SCREEN AND CASING HAVE BEEN WASHED, STEAMED, RINSED WIT DE-IONIZED OR DISTLLED WATER, RINSED WTH ISOPROPK ALCOHOL. WRAPPED WTH PROTECTVE COVERING AND STORED OFF THE GROUND.

36. PRE-PACKAGED SCREENS, CASING AND CENTRALIZERS WERE USED.

4. WORK AREA FOR SAMPLE EXAMINATION COVERED WTH CLEAN POL VETHRENE.

5. CLEAN KNIVES, GOVES, SAMPLE JARS AND LABEZS ON HAND.

6. POL YETHYENE COVER IN PLACE OVER HOLE.

7. AIR ROTARY COMPRESSED AIR SAMPLED.
COMPLANCE

DATE INITALS

11-16-89 $C A B$

11-16-89 $C A B$

N/A
11-27-89 $C A B$

11-16-89 CAB

11-16-89 CAB

11-16-89 $\subset A B$

11-27-89 $\quad C A B$

RESUL TS: No hydrocarbons were detected under ultraviolet light.

ADOIMONAL NOTES/OBSERVATIONS:

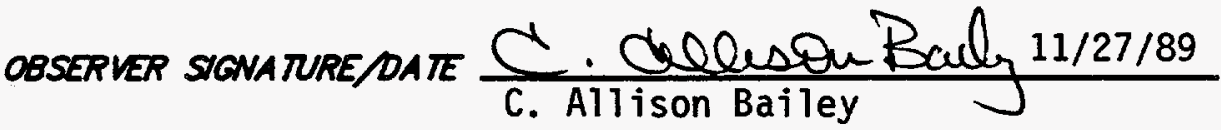




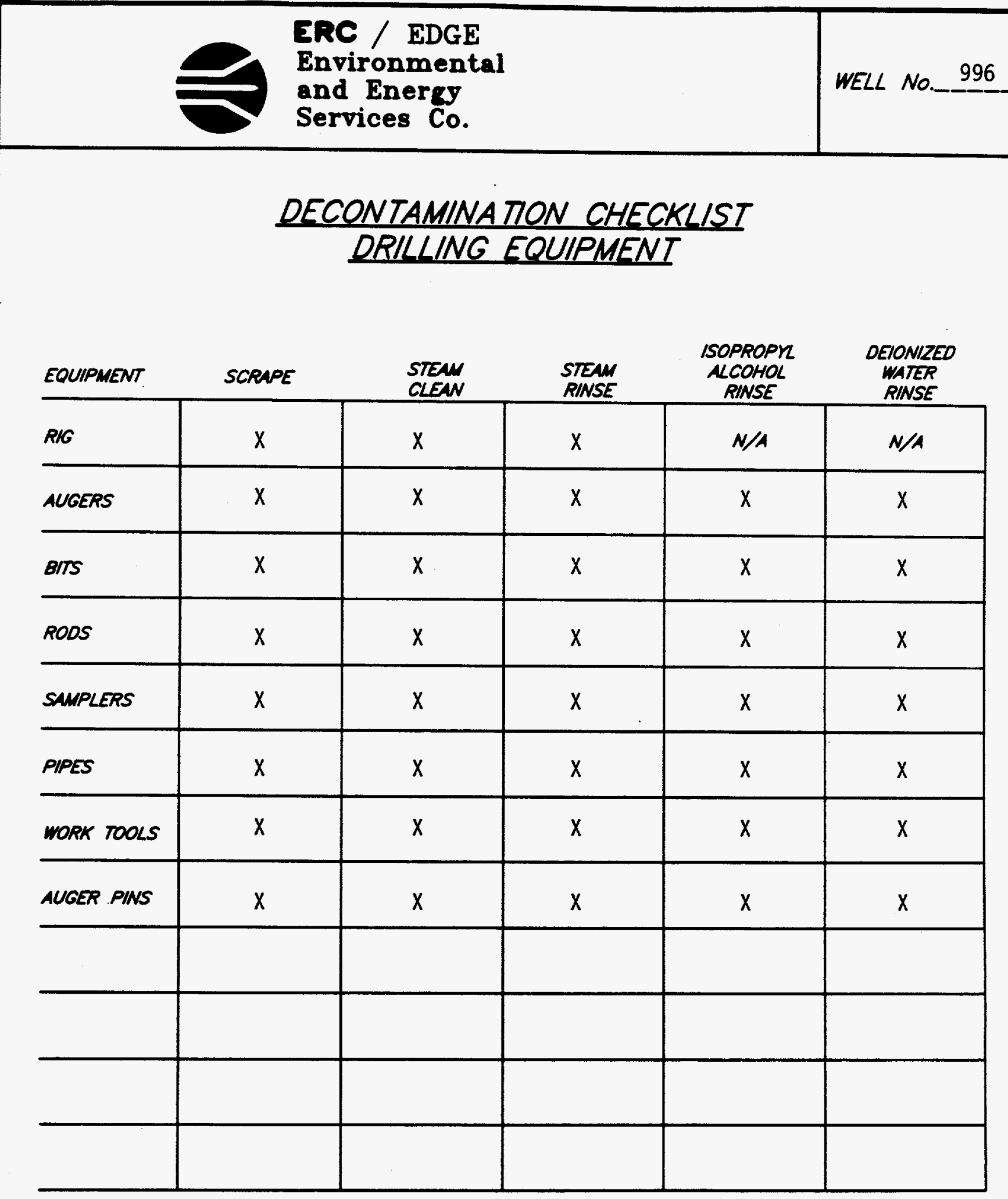

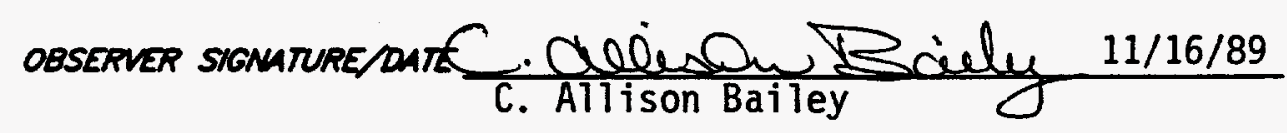




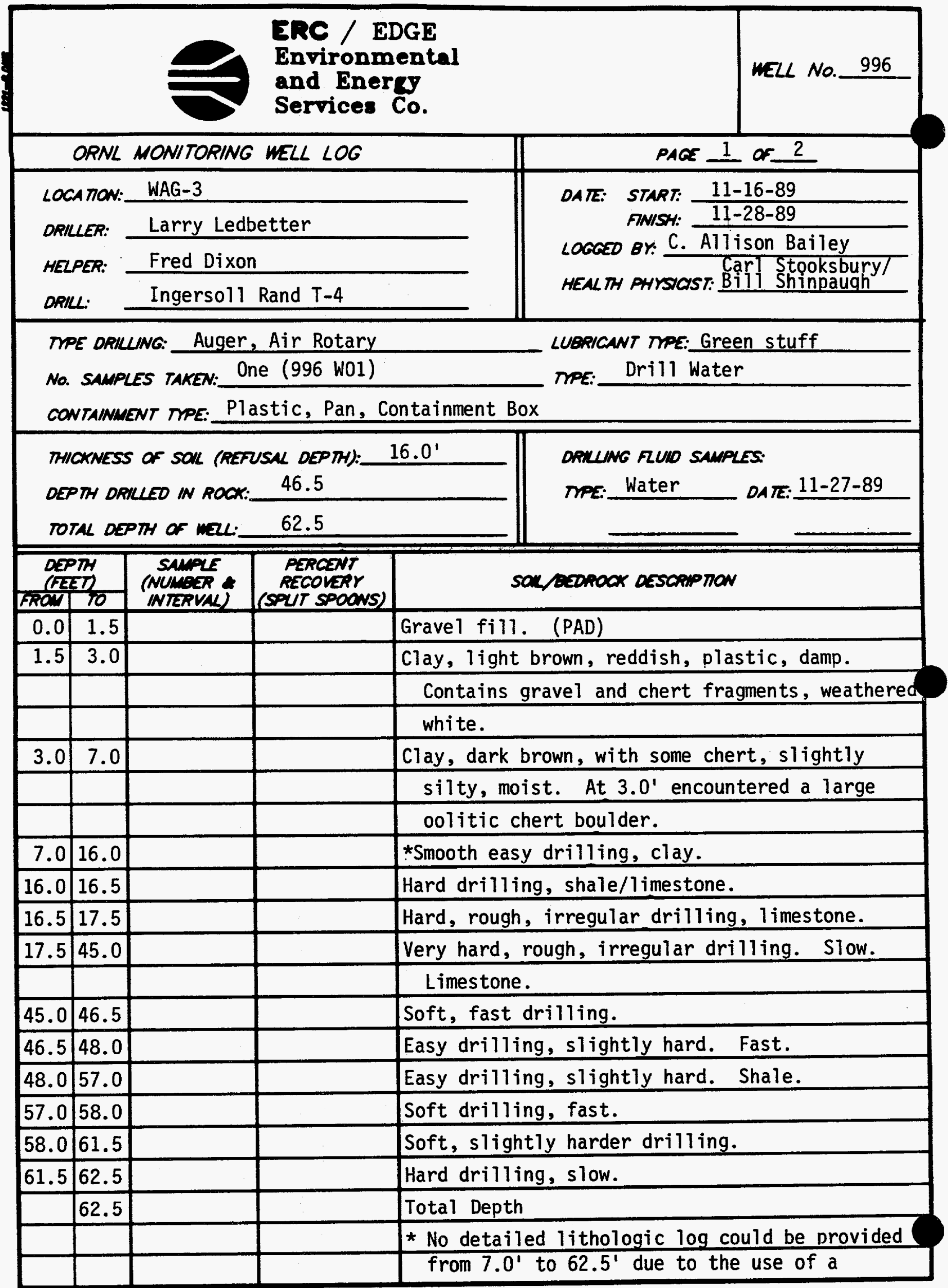




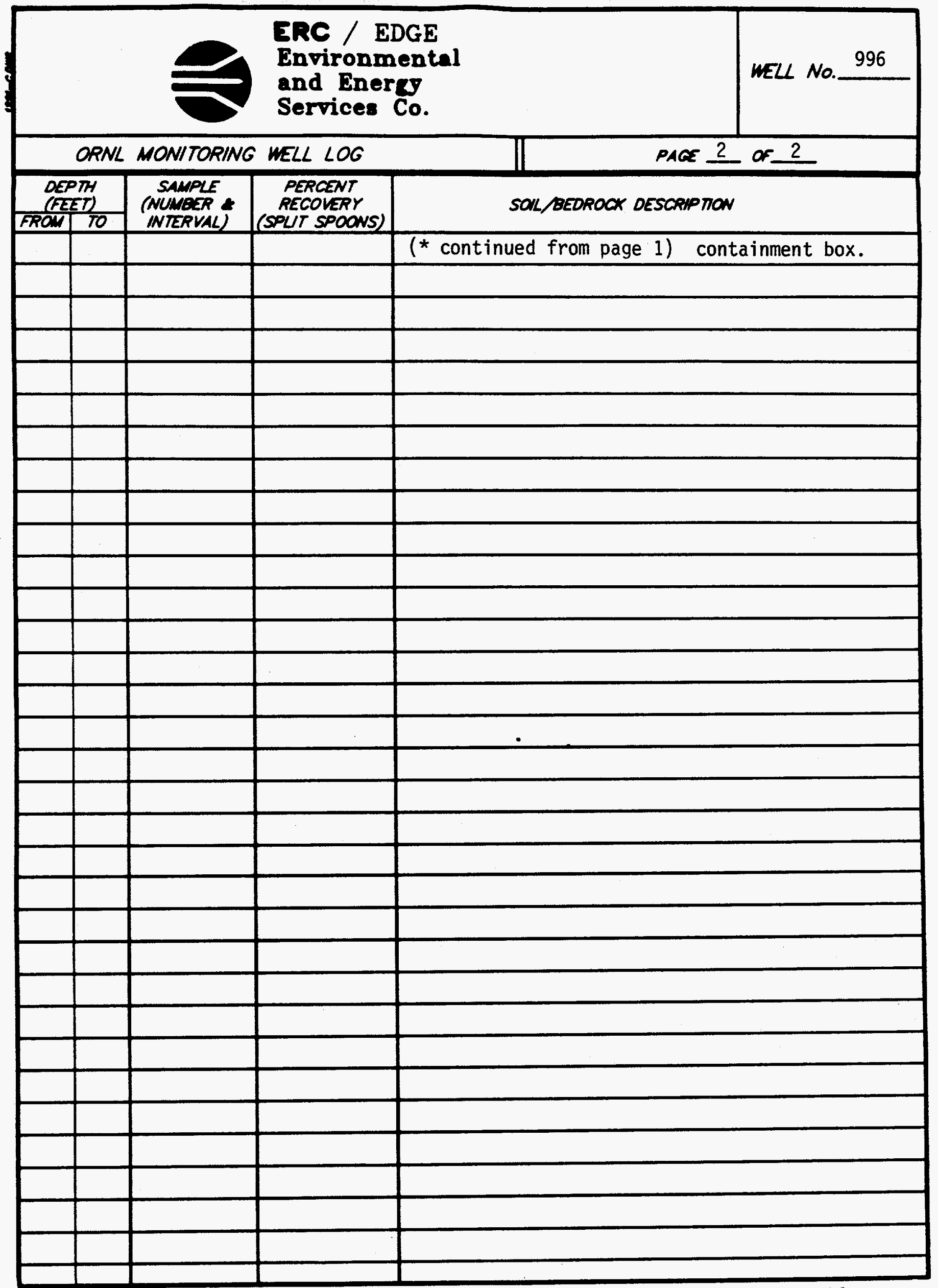

PAGE 11 of 20 . 


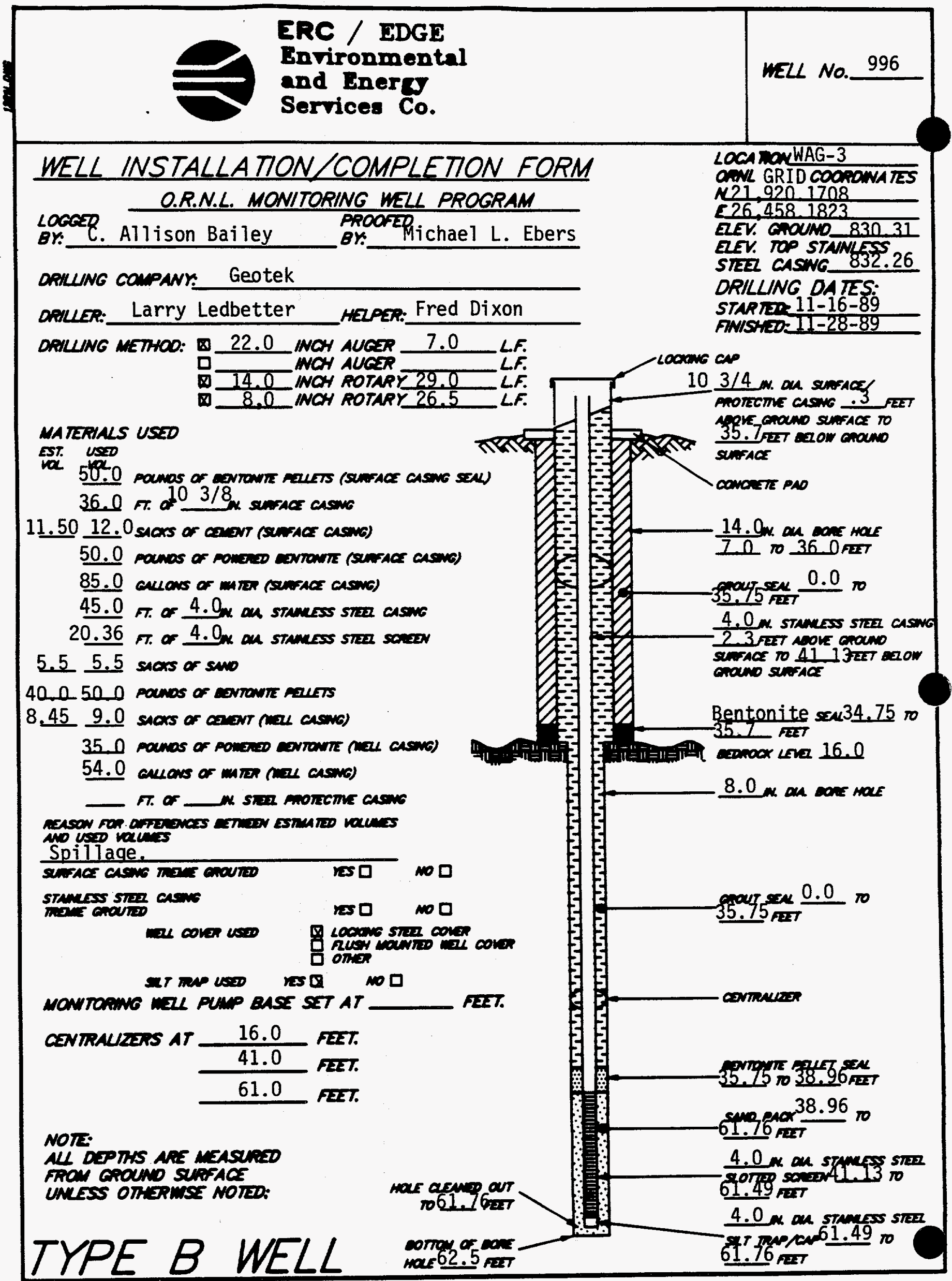

PACE 12 or 20 


\section{MONITORING WELL MATERIALS CERTIFICATION}

ITEM/MATERIAL

\begin{tabular}{|c|c|c|}
\hline & DATE USED & BATCH NUMBER \\
\hline & $11-27-89$ & 1 \\
\hline & $11-22-89$ & Stores \\
\hline & $11-27-89$ & Stores \\
\hline$\left(\begin{array}{l}r E S \\
\text { NOS }\end{array}\right.$ & $11-27-89$ & Stores \\
\hline$\left(\begin{array}{c}\text { Yes } \\
\text { NO }\end{array}\right.$ & $11-27-89$ & Stores \\
\hline$\left(\begin{array}{l}r(25 \\
n O\end{array}\right)$ & $11-27-89$ & Stores \\
\hline $\begin{array}{c}r E S \\
n O\end{array}$ & $11-27-89$ & Stores \\
\hline$\left(\begin{array}{c}\text { Res } \\
\text { NO }\end{array}\right.$ & $4-10-90$ & 5 \\
\hline & $11-27-89$ & 3 \\
\hline & $11-28-89$ & 3 \\
\hline & $11-27-89$ & Stores \\
\hline & $11-22-89$ & 2 \\
\hline
\end{tabular}

COMMENTS:

OBSERVER SINATURE DATE C.GOlisp. Baile 11/16/89 


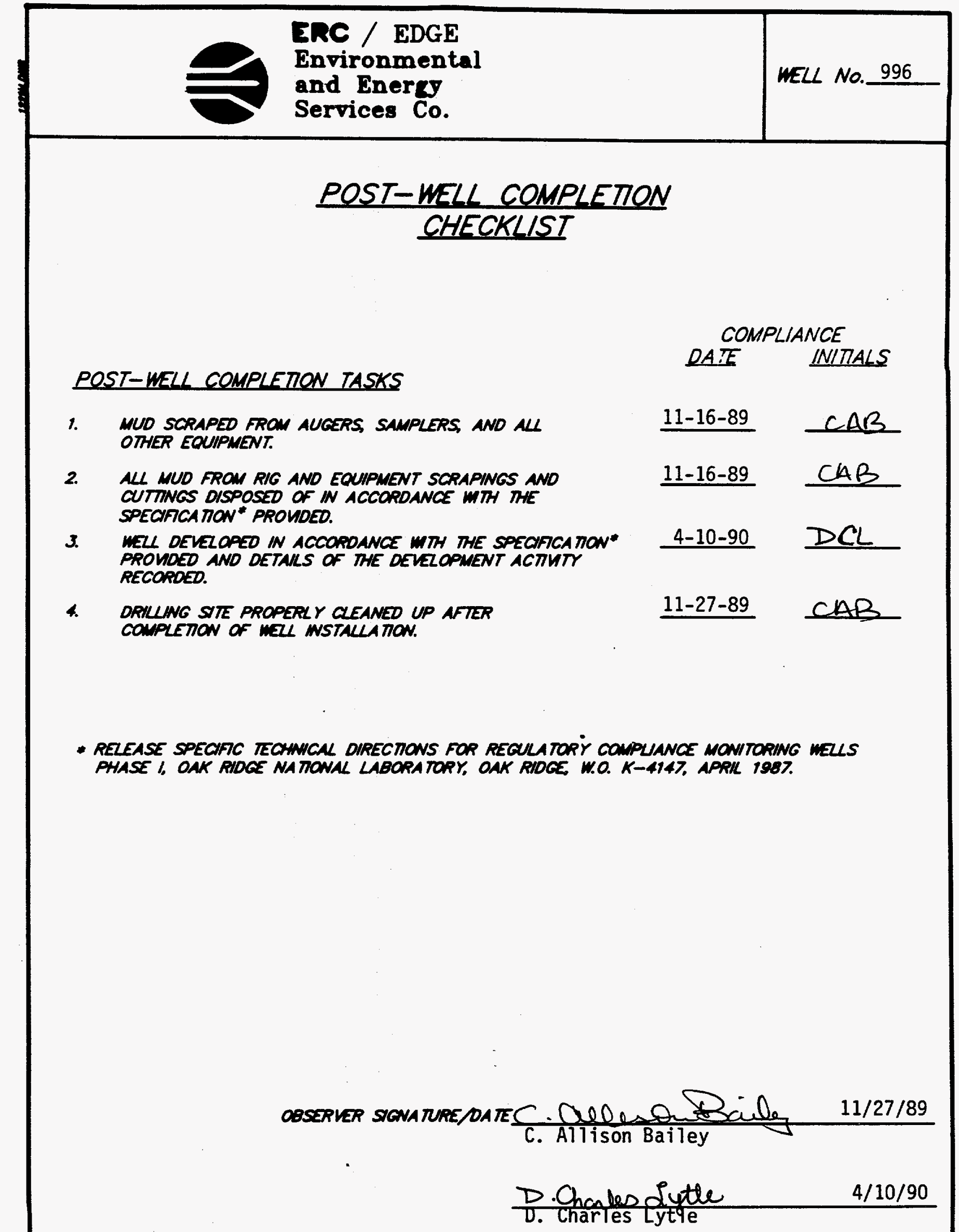




\section{ERCE}

Environmental

and Energy

WELL NO. 996

Services Co.

\section{MONITORING WELL DEVELOPMENT FORM}

DEVELOPMENT DETAILS

METHOD OF

QEVELOPMENT: Surging and Pumping

DEVELOPMENT

BEGAN DATE: $\quad 4-02-90$ TME:

DEVELOPMENT

ENDING DATE: $\quad 4-10-90$

DEVELOPMENT

OBSERVED BY:

D. Charles Lytle

ONE WELL VOLUME:

12.0

GALLONS

TOTAL GALLONS PUMPED: 413 TOTAL WELL VOLUMES PUMPED: 34.4

INITAL PH: 7.5 FNAL PH: 7.7

INITAL CONOUCTUTH (KS/cm): 878 FNAL CONOUCTUTY ( $\mathrm{HS} / \mathrm{cm}): \quad 880$

OESCRIPTON OF INITAL TURBIOITY:CCloudy

DESCRIPTION OF FNAL TURBIDITY: Clear

FINAL MEASURED TURBIDITY:

2.0 NTU's

WELL APPROVED BY: R. C. Williams MMES

ODOR MATER: None

WATER

DISCHARGED

TO:

Q GROUND SURFACE

口 STORM SEWERS

D ORUMS

口 TANK IRUCK

口 STORAGE TANKS

口 OTHER

INITAL PRE-DEVELOPMENT

WATER DEPTH:

14.6 feet from ground surface.

DEVELOPMENT OBSERVATIONS

ogserver sIGNature/OATE D. Challes Sytle

$4 / 10 / 90$

D. Charles Lytle 


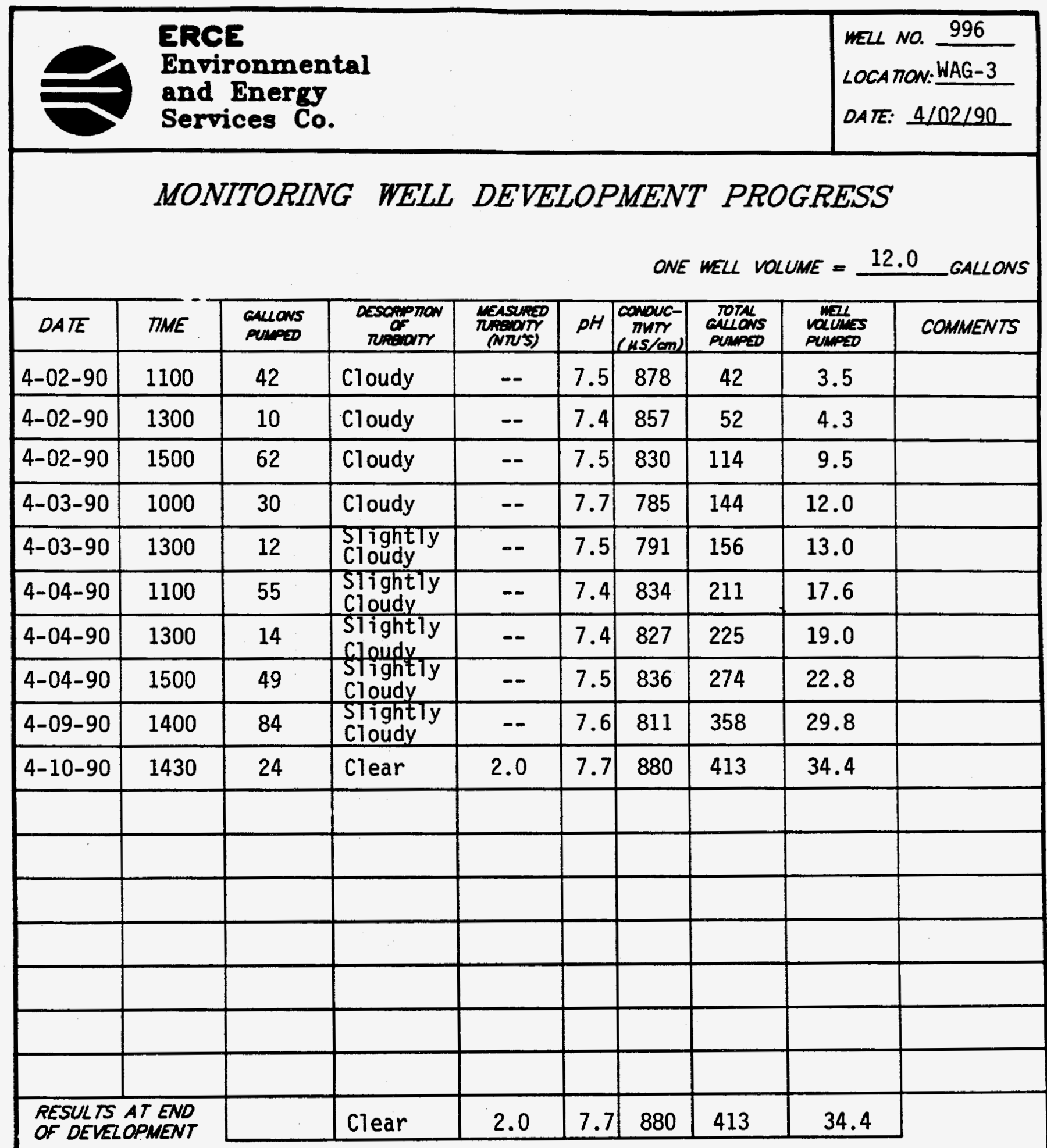

COMMENTS Nice recharger and producer, passed and moved off hole. 


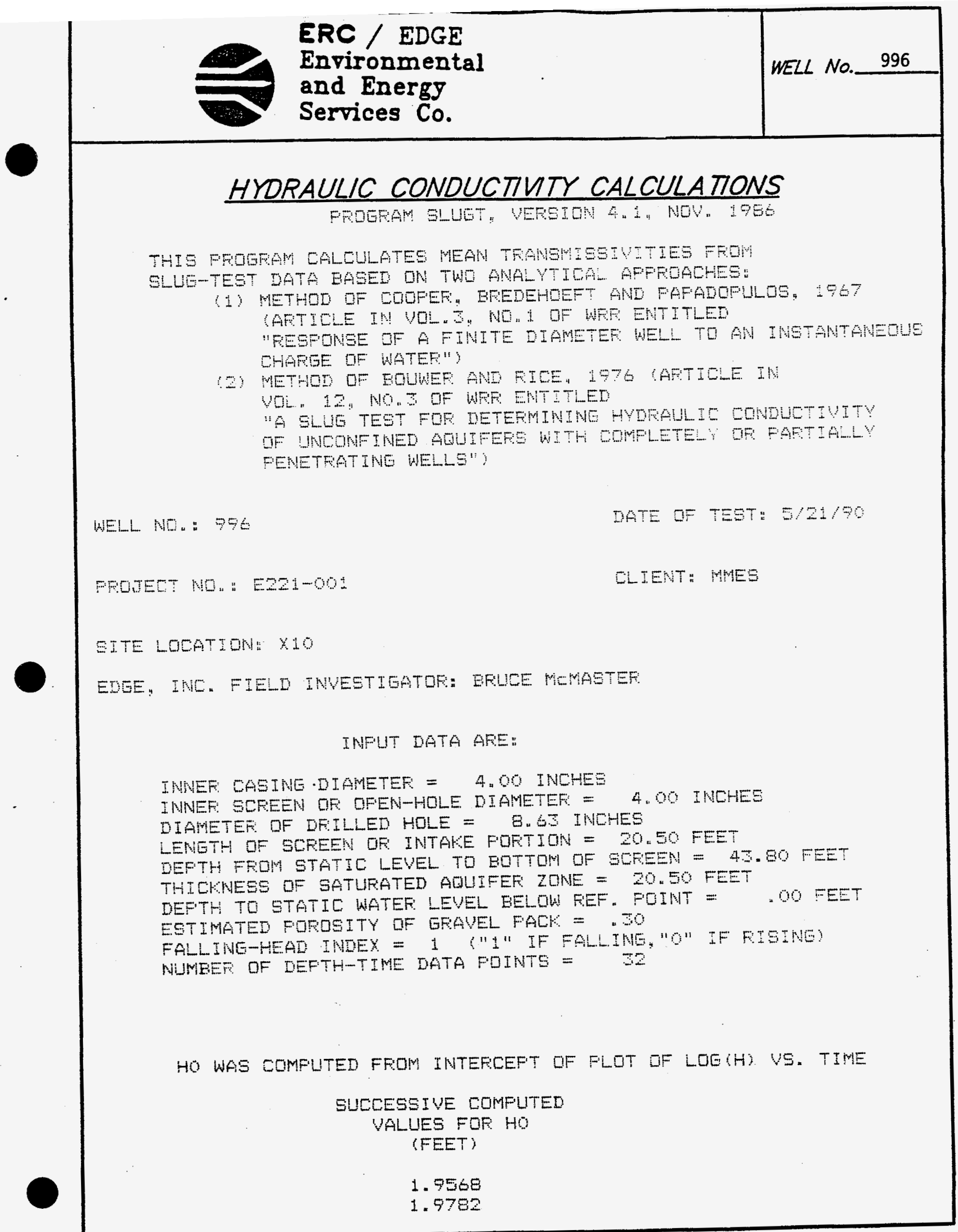

PAGE 17 of 20. 


\section{HYORAULIC CONDUCTIVTY CALCULATIONS}

\begin{tabular}{|c|c|c|}
\hline $\begin{array}{l}\text { TIHE } \\
\text { SEOOND }\end{array}$ & $\begin{array}{c}\text { DEPT TO WATES } \\
\text { OEET! }\end{array}$ & $\begin{aligned} &-1 E \\
& B E E T\end{aligned}$ \\
\hline 40.0 & 2.30 & 2.30 \\
\hline 20 "ब & 2270 & $2: 70$ \\
\hline 50,0 & 2.200 & $\because 20$ \\
\hline 40.0 & 2.150 & $\because \quad 15$ \\
\hline 50 & 2.00 & $\therefore$ बी \\
\hline $60=0$ & वक & 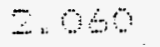 \\
\hline $7=0$ & 1.990 & I. 99 \\
\hline 90.0 & 1.90 & 2. . \\
\hline $15, \mathrm{Q}$ & 1.360 & : : \\
\hline $120: 00$ & 2.920 & 1.20 \\
\hline 190,00 & 1.790 & $\therefore 7$ \\
\hline 180.00 & $\Delta=\Delta \mathrm{O}$ & 14 \\
\hline 2400 & 150 & 1.50 \\
\hline 30.00 & 1.590 & 3.90 \\
\hline 50,00 & I. 290 & $1=29$ \\
\hline 420.00 & $1=210$ & $\angle 210$ \\
\hline 490.0 & 1,13 & 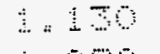 \\
\hline 540.00 & $\therefore=0$ & 50 \\
\hline 50.00 & 1.00 & 1. . \\
\hline 720,00 & .90 & $=20$ \\
\hline $\begin{array}{l}840 " \mathrm{oO} \\
960, \mathrm{o}\end{array}$ & 480 & .80 \\
\hline $\begin{array}{r}760.00 \\
1080.60\end{array}$ & $\begin{array}{l}.770 \\
.700\end{array}$ & 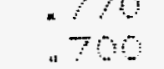 \\
\hline $\begin{array}{l}1080.00 \\
\pm 00.00\end{array}$ & $\begin{array}{l}=790 \\
.650\end{array}$ & .8 \\
\hline $\begin{array}{l}200,00 \\
1-20,00\end{array}$ & .60 & .60 \\
\hline $\begin{array}{l}4.40 \\
1440.00\end{array}$ & .540 & $=540$ \\
\hline 1560.00 & .510 & $=510$ \\
\hline 1680.00 & 480 & 400 \\
\hline 1800.00 & .450 & 470 \\
\hline 1920.00 & .450 & .430 \\
\hline $204 \% .00$ & 400 & 400 \\
\hline 260 & .400 & .40 \\
\hline
\end{tabular}

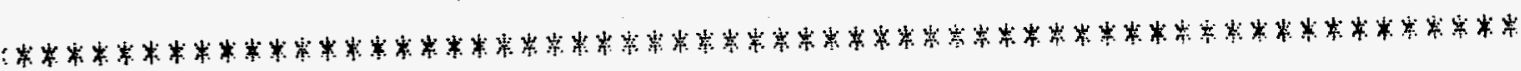

METHOD OF EOUWEF: AND RICE

COMFUTED FESULTS UEINE DIAMETEF OF DFILLED HOLE:

FEFMEAEILITY $=2.12 E-06$ FT/SECOND $\quad=6.46 E-O S$ CM

TEANGMISSIVITY $=4.34 E-O S$ FTWW2/SECOND 


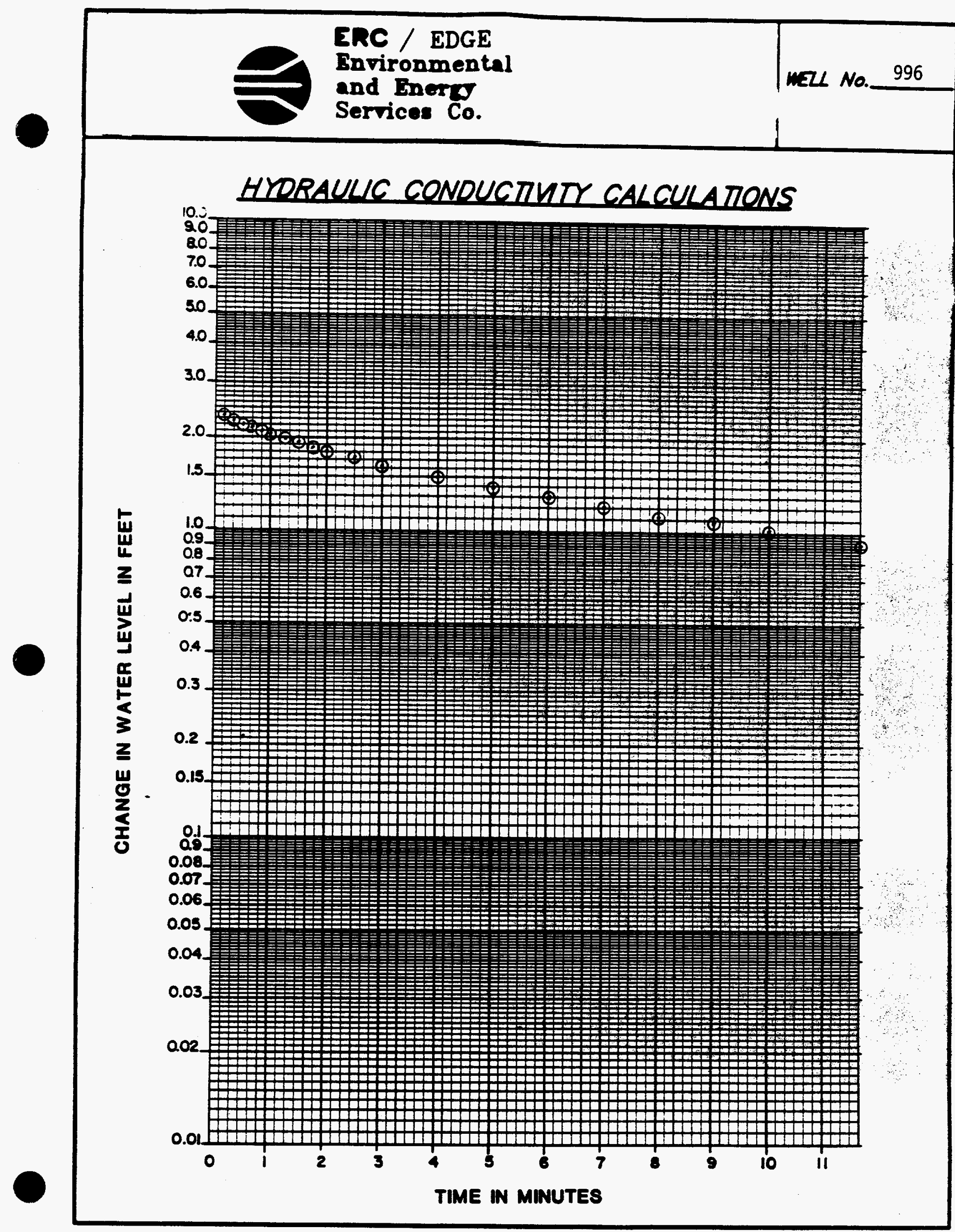




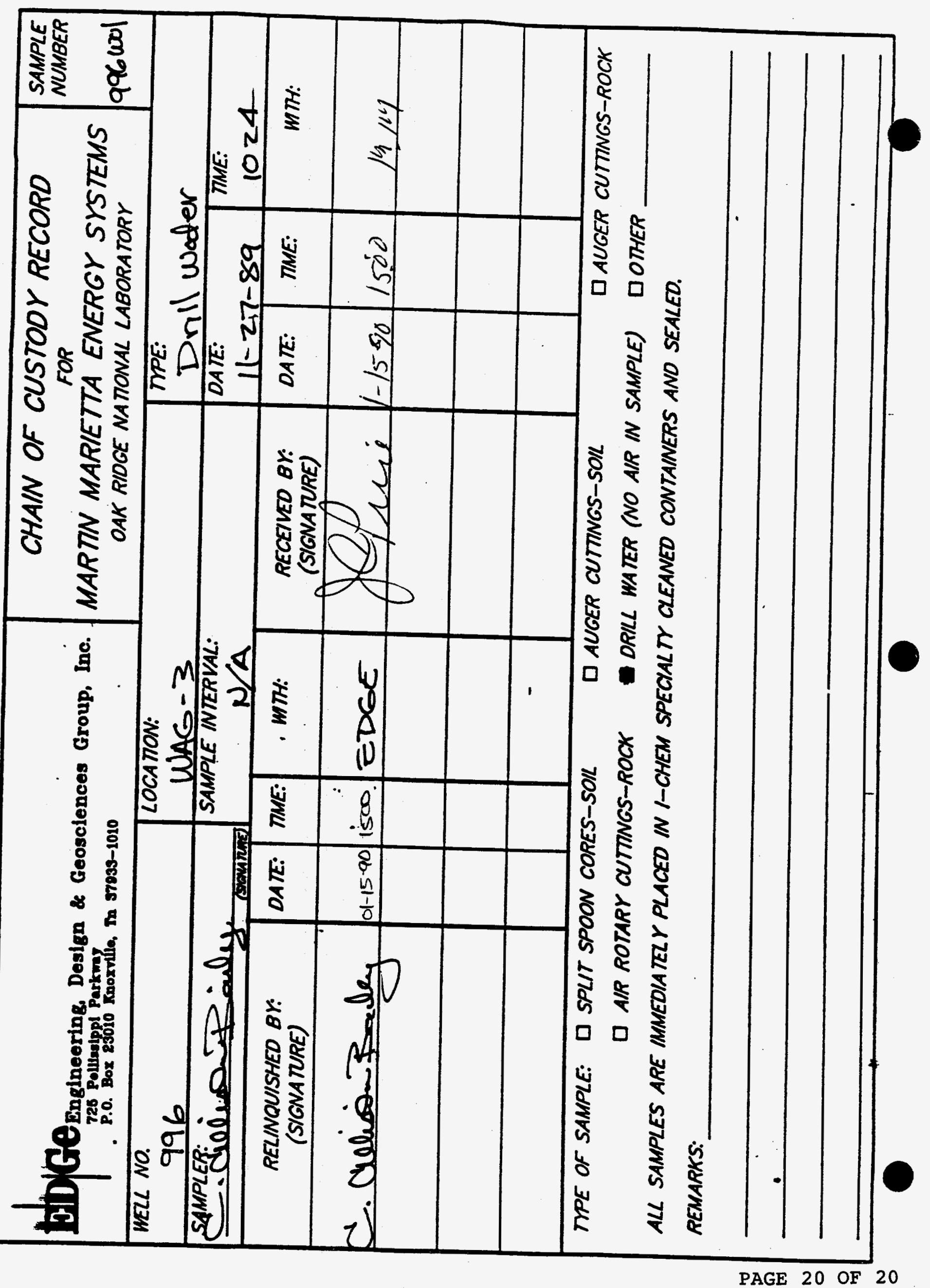




\subsection{We11 Location}

Monitoring well number 997 is located in SWSA 3. It is along the north perimeter fence of SWSA 3 . The location is shown on ORNL drawing number C3E20004 A075. Survey coordinates for this well are N 21,911.0380, E 26,467.4951 (X-10 grid) or latitude $35^{\circ}-55^{\prime}-09.71^{\prime \prime}$ and longitude $84^{\circ}-19^{\prime}-46.27^{\prime \prime}$. Coordinate data were provided by Martin Marietta Energy systems. The method used for conversion from X-10 grid to Tennessee-Lambert State Plane Coordinates came from the publication "Tennessee Valley Authority Data Services Branch and Mapping Services Branch, Oak Ridge, Tennessee, DOE Plant Control, November 6, 1985, Field Book: EsS-3115, pp. 1-20." The latitude and longitude were calculated by Adams Craft Herz Walker Engineering, Inc., using methods from the U.S. Coast and Geodetic Survey Publication 62-4, "State Plane Coordinates by Automatic Data Processing."

\subsection{Driling Information}

Well number 997 was drilled by Geotek Engineering Company. Schramm and Ingersoll-Rand Air Rotary rigs were used to drill this boring for monitor well installation under operation of George Akins and Larry Ledbetter with the assistance of steve Kirk and Fred Dixon. Drilling commenced on 11-9-89 and was finished on 11-27-89. Paragraph 2.4.1 includes a detailed 
discussion of the well installation and a well schematic is included on the well installation/ completion form. A synopsis of the drilling activity follows. This information was typed directly from field notes and was edited only when necessary for clarification.

11-9-89 The Schramm rig was mobilized to the staked location and set up on plastic. Split spoon samples were taken from the surface to 11.61 . The boring was then augered with a 6" auger to refusal at 11.61 . The boring was then augered with a $20 "$ auger to 8.0 feet. Set 7.0 feet of $16^{\prime \prime}$ surface casing and grouted with 4 sacks of cement with $5 \%$ bentonite. The Schramm rig was moved off the hole.

11-13-89 The rig and equipment were decontaminated and mobilized to the site. The diverter head was connected and a 14" boring was advanced to $15.0^{\prime}$ ' with a tricone bit. A $103 / 4 "$ surface casing was installed to a depth of $14.65^{\prime}$ and a bentonite seal was poured into the annulus to 13.25 '.

11-14-89 The annulus was tremied grouted to the surface.

11-15-89 The rig and equipment were decontaminated and mobilized to the site.

11-16-89 The Ingersoll-Rand and equipment were set up and the boring was drilled to a total depth of 33.5'. With an 8-inch tricone bit. This was originally to be a deep boring but because water was encountered 
between 16.0 and $18.0^{\prime}$, it was decided by Bill McMasters to make this the shallow boring. This boring will be completed after the deep boring is set.

11-27-89 The boring caved to 33.0' and sand was added to $30.0^{\prime}$ ' so a $15.0^{\prime}$ ' screen could be utilized to encounter the water zone. A 2.0" stainless steel screen and casing were installed to a depth of 29.92'. The sand was tremie grouted to $11.95^{\prime}$ and $a$ bentonite seal poured to $9.64 '$. No air or water samples were taken because it was thought this would be a deep boring and drilling was completed before samples could be taken.

11-28-89 The annulus was tremie grouted using 2.5 bags of cement with $5 \%$ bentonite.

This well was logged by ERC Environmental and Energy Services Co., Inc., hydrogeologists Timothy A. Lee and c. Allison Bailey. All well construction materials and supplies were from Martin Marietta Energy Systems approved batches. The batch origin of individual items is shown on the included Monitoring Well Materials Certification form.

\subsection{Technical Information}

\subsection{Decontamination Procedures}

The drilling rig, down hole tools, surface casing, stainless steel screen, stainless steel casing, centralizers, and stainless steel silt trap underwent 
the cleaning decontamination procedures outlined in the drilling specifications (Release specific Technical Directions for Regulatory Compliance Monitoring Wells Phase 1 , Oak Ridge National Laboratory, Oak Ridge, w.0. K-4147, April 1987, pgs. 2-4). A checklist of the cleaned materials is included with this data package.

\subsection{Geology}

WAG 3 is located in Melton Valley which is in the Valley and Ridge Physiographic Province of East Tennessee. WAG 3 is underlain by limestone, siltstone and shale of the Middle ordovician Chickamauga Group. The Chickamauga Group consists of eight units, designated by letters "A" to "K" (Stockdale, 1951). WAG 3 is underlain by units E, F, G and H. These units consist of thin bedded nodular limestone with clay and shale partings. A portion of unit $\mathrm{H}$ and unit $F$ consists of calcareous siltstone alternating with beds of olive gray to maroon shale. Strike and dip varies from $N 45^{\circ} \mathrm{E}$ to $\mathrm{N} 55^{\circ} \mathrm{E}$ and $25^{\circ}$ to $35^{\circ}$ southeast, respectively.

\subsection{Sample collection}

One soil sample was collected during drilling, placed in an I-CHEM specialty cleaned glass container, sealed and submitted to sample Receiving, Analytical Chemistry Division, Bldg. 4500S, ORNL. A chain of custody form for this sample is included with this 
data package. Soil sample 997S01 was collected in the split spoon interval from 10.7 feet to 11.0 feet on 11-9-89.

A bulk density soil sample was collected from the split spoon sample interval from 6.0 to 6.3 feet. The sample was measured and weighed, and a bulk density of 2.04 grams $/ \mathrm{cm}^{3}$ was calculated.

\subsection{Installation and Development}

\subsubsection{Installation}

This was a "Type $D$ " well. A 22.0-inch diameter boring was augered from ground surface to 8.0 feet. A 15 1/4-inch diverter casing was installed from surface to 8.0 feet below ground surface and grouted in place. The boring was then extended with a 14.0-inch air rotary tricone roller bit from 8.0 feet to 15.0 feet. A 10 3/4-inch diameter string of decontaminated steel surface casing was installed from 0.0 feet to 14.65 feet, sealed with a 1.4-foot bentonite pellet layer from 14.65 feet to 13.25 feet, and tremie grouted in place. The surface casing minimizes potential cross contamination between the regolith and bedrock water bearing zones. After the surface casing was installed, the air rotary method was used to drill an 8-inch diameter boring to a total depth of 33.5 feet. A 2-inch diameter stainless steel screen with threaded bottom cap was installed from 29.92 feet to 13.82 feet. A 2-inch diameter stainless steel casing was installed from the top of the screen at 13.82 feet and extended 1.77 feet above ground surface. A sandpack 
was then tremied into the annular space from 33.0 to 11.95 feet, with a 2.31-foot bentonite pellet seal poured into the annular space above the sandpack from 11.95 to 9.64 feet. The annular space from the top of the bentonite seal to the surface was tremie grouted with a cement/bentonite slurry. A detailed schematic of the well is included on the well installation/ completion form.

\subsubsection{Well Development}

Well number 997 was developed to remove drill cuttings, silt, and other fines. The monitoring well was developed using a Geoguard pump with an air compressor. All pumps were cleaned prior to use according to specified cleaning procedures (see Paragraph 2.1). The well was developed until a measured total of 812 gallons of water had been evacuated and the clarity of the discharge water was approved by the company representative. The final turbidity value measured at completion was $5.0 \mathrm{NTU}$ 's. A development form showing the exact method of development and other pertinent data is appended.

\subsubsection{Installation of Dedicated Monitoring Well Pump}

After the well was developed, a Geoguard Model No. 5614 dedicated monitoring well pump was installed on 4-24-90 at a depth of 59.4 feet below ground surface. 
These pumps are decontaminated at American Sigma and are sent prepackaged. A copy of the pump certification is kept on file at ORNL.

\subsection{Hydraulic conductivity Testing}

Well number 997 was tested for the determination of hydraulic conductivity of the aquifer in the vicinity of the well screen. This was accomplished by instantaneously adding a known quantity of water to the monitoring well and measuring the recovery of the water level over time. The changing water levels were measured using a Druck 15 psig pressure transducer and an Omnidata Datapod II data recorder. The hydraulic conductivity value of $4.98 \times 10^{-4} \mathrm{~cm} / \mathrm{second}$ (shown as permeability on the hydraulic conductivity calculations printout attached) was calculated using the Bouwer and Rice method. A computer printout of the hydraulic conductivity calculations is included in this data package. 


\section{PRE-DRILLING CHECKLIST FOR MONITORING WELLS}

BRE-DRILUNG TASKS

1. EXCAVTION PERMIT OBTAINED

2. ALL EQUIPMENT HAS BEEN CLEANED BEFORE DRILUNG.

3a. SCREEN AND CASING HAVE BEEN WASHED, STEAMED, RINSED WTH DE-IONIZED OR DISTILED WATER, RINSED WTH ISOPROPV ALCOHOL, MRAPPED WTH PROTECTVE COVERING AND STORED OFF THE GROUND.

36. PRE-PACKAGED SCREENS, CASING AND CENTRALIZERS MERE USED.

4. WORK AREA FOR SAMPLE EXAMINATION COVERED WTH CLEAN POL YETHRENE.

5. CLEAN KNIVES, GLOVES, SAMPLE JARS AND LABELS ON HANO.

6. POL YETHRENE COVER IN PLACE OVER HOLE.

7. AIR ROTARY COMPRESSED AIR SAMPLED.
COMPUANCE

DATE INITALS

11-09-89 CAB

11-09-89 CAB

$N / A$

RESULTS:

ADDIMONAL NOTES/OBSERVA TONS:

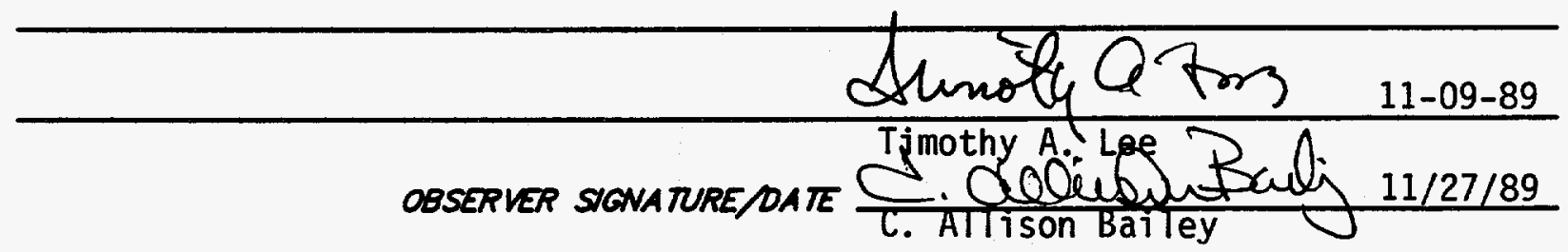


ERC / EDGE

Environmental

and Energy

WELL No. 997

$\frac{\text { DECONTAMINA TION CHECKLIST }}{\text { DRILLING EOUIPMENT }}$

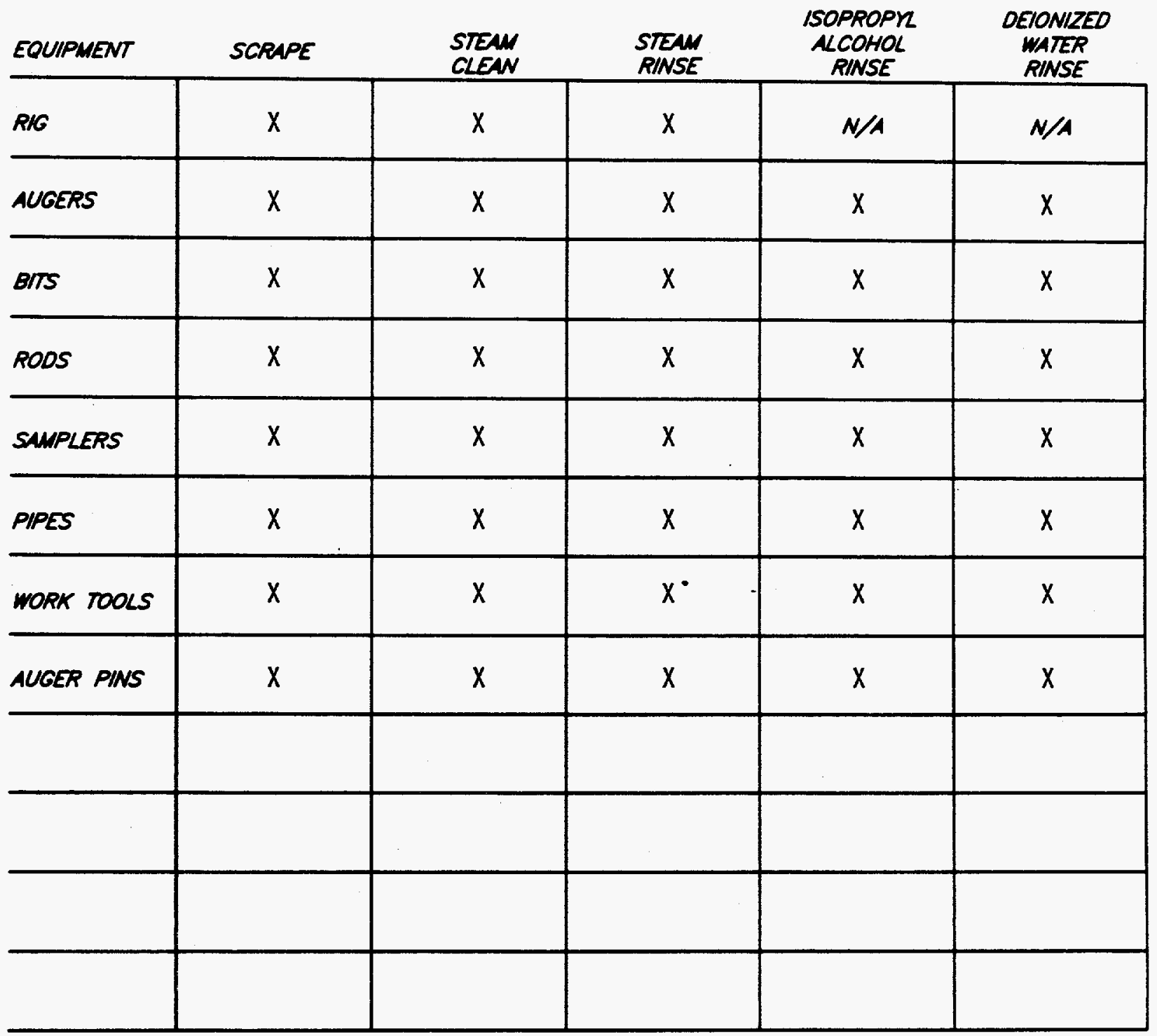

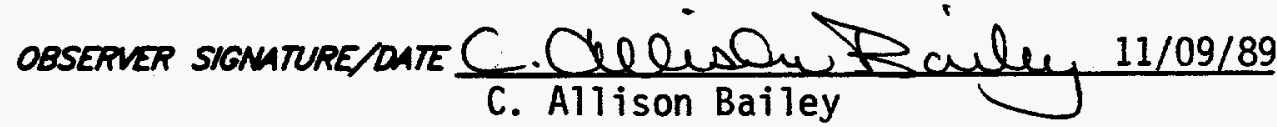




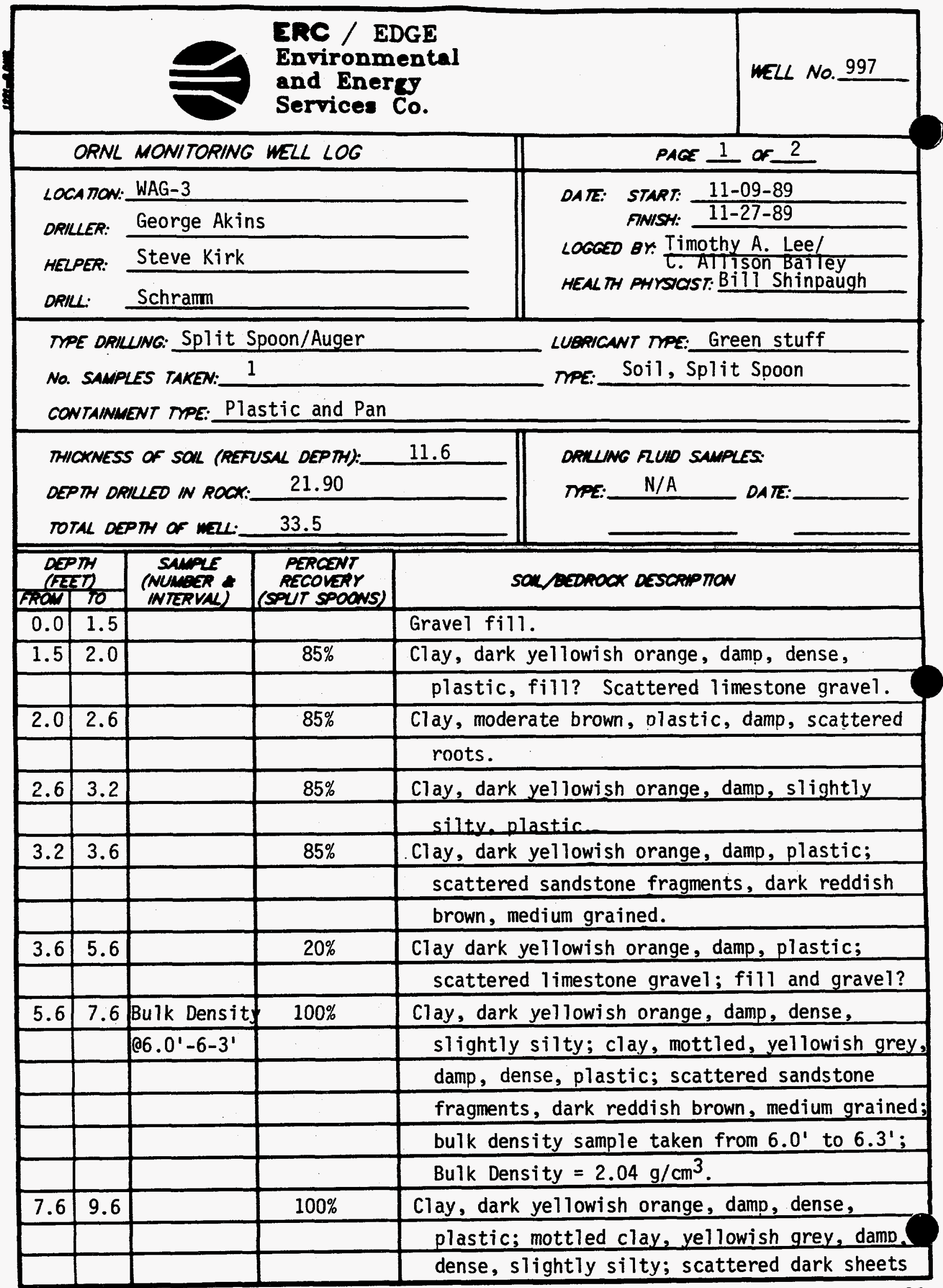




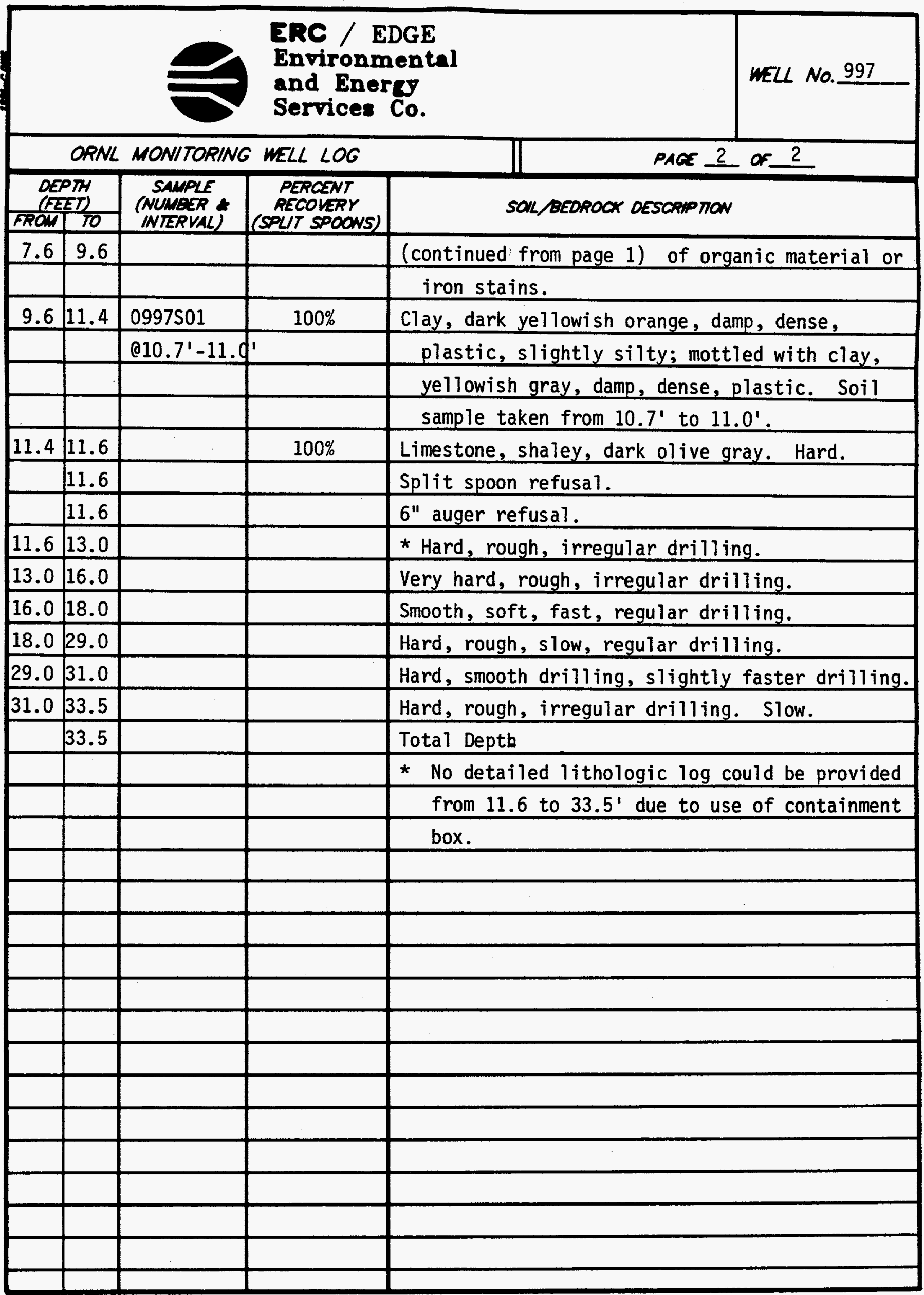




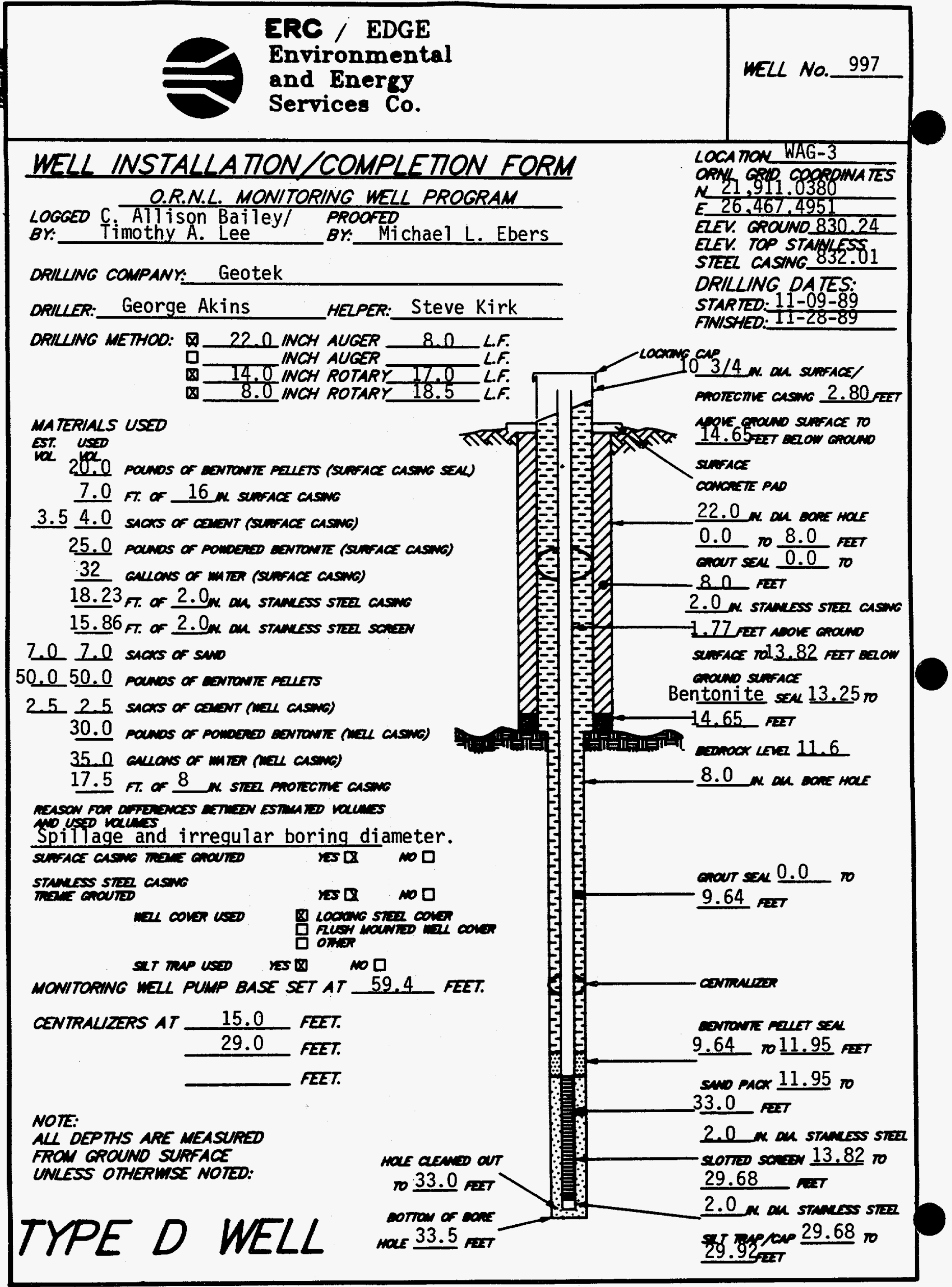

PAGE 12 of 21 


\section{MONITORING WELL MATERIALS CERTIICA TON}

ITEM/MATERIAL

\begin{tabular}{|c|c|c|}
\hline ITEM/MA TERIAL & DAIE USED & BATCH NUMAER \\
\hline \multirow{2}{*}{ SAND } & & \\
\hline & $11-27-89$ & 1 \\
\hline \multirow{2}{*}{ BENTONITE } & $11-13-89$ & Stores \\
\hline & $11-27-89$ & Stores \\
\hline (PREPACKAGED O $\begin{array}{c}\text { nES } \\
\text { NO }\end{array}$ & $11-27-89$ & 1 \\
\hline (PREPACKAGED 1 TES & $11-27-89$ & 1 \\
\hline STAINLESS STEEL CENTRALIZERS (PREPACKAGED D RES) & $11-27-89$ & 1 \\
\hline (PREPACKAGED 5 RES & $11-27-89$ & 1 \\
\hline (PREPACKACED D NOS) & $4-24-90$ & 5 \\
\hline \multirow{2}{*}{ GROUT } & $11-14-89$ & 3 \\
\hline & $11-27-89$ & 3 \\
\hline WELL COVERS & $11-27-89$ & 1 \\
\hline SURFACE CASING & $11-13-89$ & 2 \\
\hline
\end{tabular}

COMMENTS:

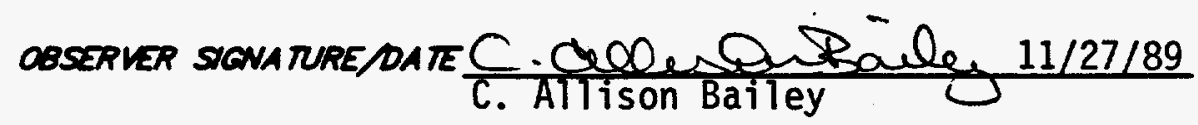


ERC / EDGE

Environmental

and Enerey

WELL NO. 997

Services Co.

\section{POST-WELL COMPLETION \\ CHECKLIST}

\section{POST-MELL COMPLETION TASKS}

\section{COMPLIANCE \\ DATE INITALS}

1. MUD SCRAPED FROM AUGERS, SAMPLERS, AND ALL OTHER EQUIPMENT.

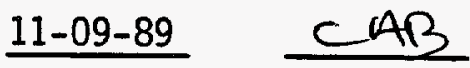

11-09-89 $C A B$

CUTINGS DISPOSED OF IN ACCOROANCE WITH THE

SPECATCA IION PROVDED.

3. WEL DEVELOPED IN ACCOROANCE WTH THE SPECOFCATON" PROVOED AND DETANS OF THE DELELOPMENT ACTVTY RECORDED.

4. ORILNG SITE PROPERLY CLEANED UP AFTER COMPLETON OF MEL INSTALLATON.

- RELEASE SPECATC TECANICAL DIRECTIONS FOR REGULATORY COMPLANCE MONITORING WEZLS PHASE I, OAK RIDGE NATIONAL LABORATORY, OAK RIDGE W. K-4147, APRK 1987.

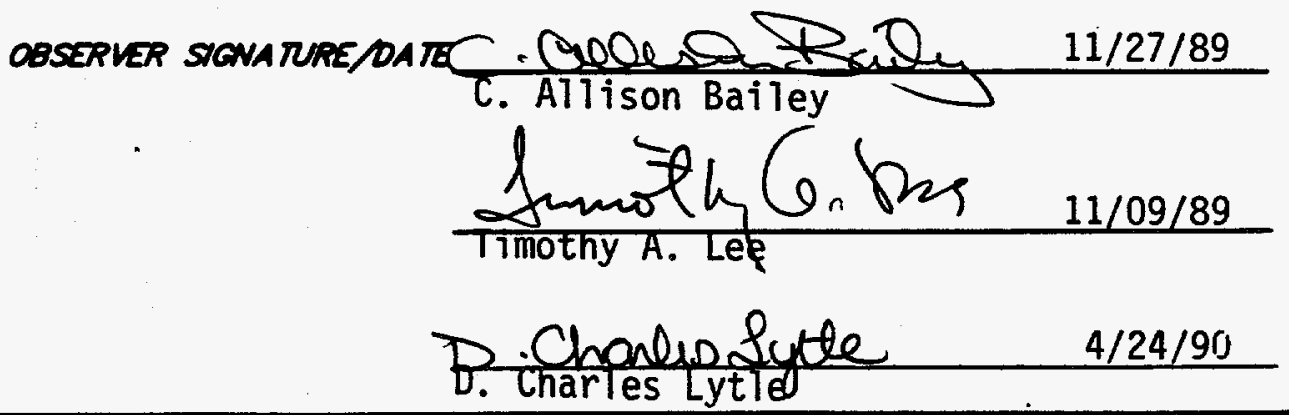




\section{MONITORING WELL DEVELOPMENT FORM}

DEVELOPMENT DETAILS

METHOD OF
DEVELORMENT: Surging and Pumping

DEVELOPMENT:
BEGAN DAIE: TME:

4-24-90

DEVELOPMENT

ENDING DATE:

DEVELOPMENT

OBSERVED BY.

D. Charles Lytle

ONE WELL VOLUME: 44.7 GALLONS

TOTAL GALLONS PUMPED: 812 TOTAL WELL VOLUMES PUMPED: 18.2 INITAL PH: 7.6 FNAL PH: 7.5

INITAL CONDUCTUTY ( $\mathrm{KS} / \mathrm{cm}$ ): 785 DESCRIPTON OF INITAL TURBIOITY:

DESCRIPTON OF FINAL TURBIOITY: Clear

FINAL MEASURED TURBIOITY: 5.0 NTU'S

WELL APPROVED BY: R. C. Williams MMES

ODOR

OF MATER:

Sulfer Smell

WA TER

DISCHARGED

Q GROUND SURFACE

TO:

D STORM SEWERS

D DRUNS

FNAL CONDUCTUTY ( $\mu \mathrm{s} / \mathrm{cm}): 684$

jams
11
SURACE
ERS

INITAL PRE-DEVILPMENT

WATER DEPTH:

6.5 feet from ground surface.

\section{DEVELOPMENT OBSERVATIONS}




\begin{tabular}{|l|l|}
\hline $\begin{array}{l}\text { ERCE } \\
\text { Environmental } \\
\text { and EnergJ } \\
\text { Services Co. }\end{array}$ & $\begin{array}{l}\text { WEL NO. } \frac{997}{} \\
\text { LOCA NON: WAG-3 } \\
\text { OATE: } 4 / 02 / 90\end{array}$ \\
\hline
\end{tabular}

\section{MONITORING WELL DEVELOPMENT PROGRESS}

\begin{tabular}{|c|c|c|c|c|c|c|c|c|c|}
\hline \multicolumn{4}{|c|}{ ONE WELL VOLUME $=44.7$} & & & & & & _GALLONS \\
\hline DATE & TME & $\begin{array}{l}\text { ancows } \\
\text { Punped }\end{array}$ & $\begin{array}{l}\text { ossoponow } \\
\text { of } \\
\text { nntorr }\end{array}$ & 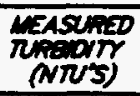 & $P H$ & $\begin{array}{l}\text { conouc- } \\
\text { nnTr } \\
(\mu S /(\mathrm{cm})\end{array}$ & 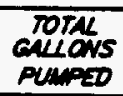 & $\begin{array}{l}\text { melu } \\
\text { voumes } \\
\text { pumped }\end{array}$ & COMMENTS \\
\hline $4-02-90$ & 1300 & 149 & Cloudy & -- & 7.6 & 785 & 149 & 3.3 & \\
\hline $4-02-90$ & 1500 & 24 & Cloudy & -- & 7.5 & 798 & 173 & 3.9 & \\
\hline $4-03-90$ & 1000 & 35 & Cloudy & -- & 7.6 & 737 & 208 & 4.7 & \\
\hline $4-03-90$ & 1300 & 18 & Cloudy & -- & 7.5 & 744 & 226 & 5.1 & \\
\hline $4-04-90$ & 1100 & 51 & Cloudy & -- & 7.5 & 804 & 277 & 6.2 & \\
\hline $4-04-90$ & 1300 & 24 & Cloudy & -- & 7.5 & 825 & 301 & 6.7 & \\
\hline $4-06-90$ & 1400 & 82 & $\begin{array}{l}\text { Slight7y } \\
\text { cloudv }\end{array}$ & -- & 7.5 & 820 & 383 & 8.6 & \\
\hline $4-17-90$ & 1430 & 132 & $\begin{array}{l}\text { Slightly } \\
\text { cloudy }\end{array}$ & -- & 7.6 & 802 & 515 & 11.5 & \\
\hline $4-19-90$ & 1330 & $\overline{159}$ & $\begin{array}{l}\text { Slight } \\
\text { cloudy }\end{array}$ & -- & 7.4 & 708 & 674 & 15.1 & \\
\hline $4-24-90$ & 1430 & 138 & Clear & 5.0 & 7.5 & 684 & 812 & 18.2 & \\
\hline & & & & & & & & & \\
\hline & & & & & & & & & \\
\hline & & & & & & & & & \\
\hline & & & & & & & & & \\
\hline & & & & & & & & & \\
\hline & & & & & & & & & \\
\hline & & & & & & & & & \\
\hline $\begin{array}{l}\text { RESULTS } \\
\text { OF DEVEL }\end{array}$ & $\begin{array}{l}\text { TEND } \\
\text { DMENT }\end{array}$ & & Clear & 5.0 & 7.5 & 684 & 812 & 18.2 & \\
\hline
\end{tabular}

COMMENTS Fast recharger and producer. Cleared up fast. Passed and moved to another hole.

* Had a sulfur smell when we first started pumping, after a couple of days the smell disappeared. 


\section{HYORAULIC CONDUCTIVTY CALCULATIONS}

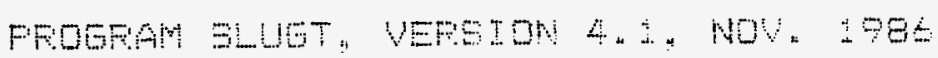

THE FROCAAM CALCULATES MEAN TRANENISETUTTES FROW

SLUE-TEST DATA EABED ON TWO ANALYTCAL AFFPCACHES:

(1) METHOD OF COOPEF, PECDEHOEFT AND PAPADOFULOS 1967

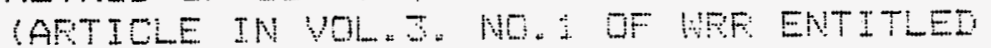
"RESPONSE OF A FINTE DAMETEF WEL TO AM INETANTANEOUE CHAFEE DF WATEE"?

$a$ METHOD OF BOUWEE AND FICE 1776 ASTICE IN UOL. $12 ;$ NO 5 OF WRE ENTTTED

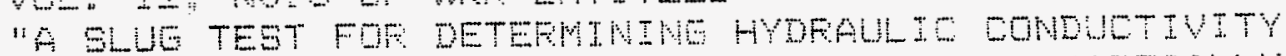
OF UNCONFINED AOUIFEPS WTH COMPLEEY OR PARTALI FENETFAT ING WELES"

WELL NG: 797 DATE OF TEET:

FROJEET NO.: E221-OO1 CLTENT: WES

BITE LOEATONA XIO

EDEE: ZNC. FIELD TMUESTIGATUER ERUEE MCHASTEF

\section{INFUT DATA ARE:}

INMER CAEINE DIAMETEF = 2.00 INCHES

INNEF SCFEEN OF OPEN-HOLE DIAMETEF =

DIAMETEF OF DFILLED HOLE = 8.35 INCHES

LENGTH OF SCREEN OR INTAKE FOFTION = 15.00 FEET

DEFTH FROM STATIC LEVEL TO BOTTOM OF ECPEEN = 16.20 FEET

THICMNES OF SATURATED AQUIFEF ZONE $=15.80 \mathrm{FEET}$

DEFTH TO STATIC WATER LEVEL BELOW FEF "FOINT = "OO FEET

ESTTMATED POFOSITY DF GRAVEL FACK = 30

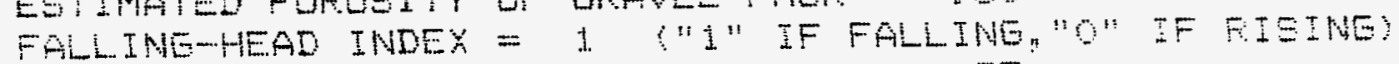

NUMEER OF DEFTH-TIME DATA PONTS = 2 


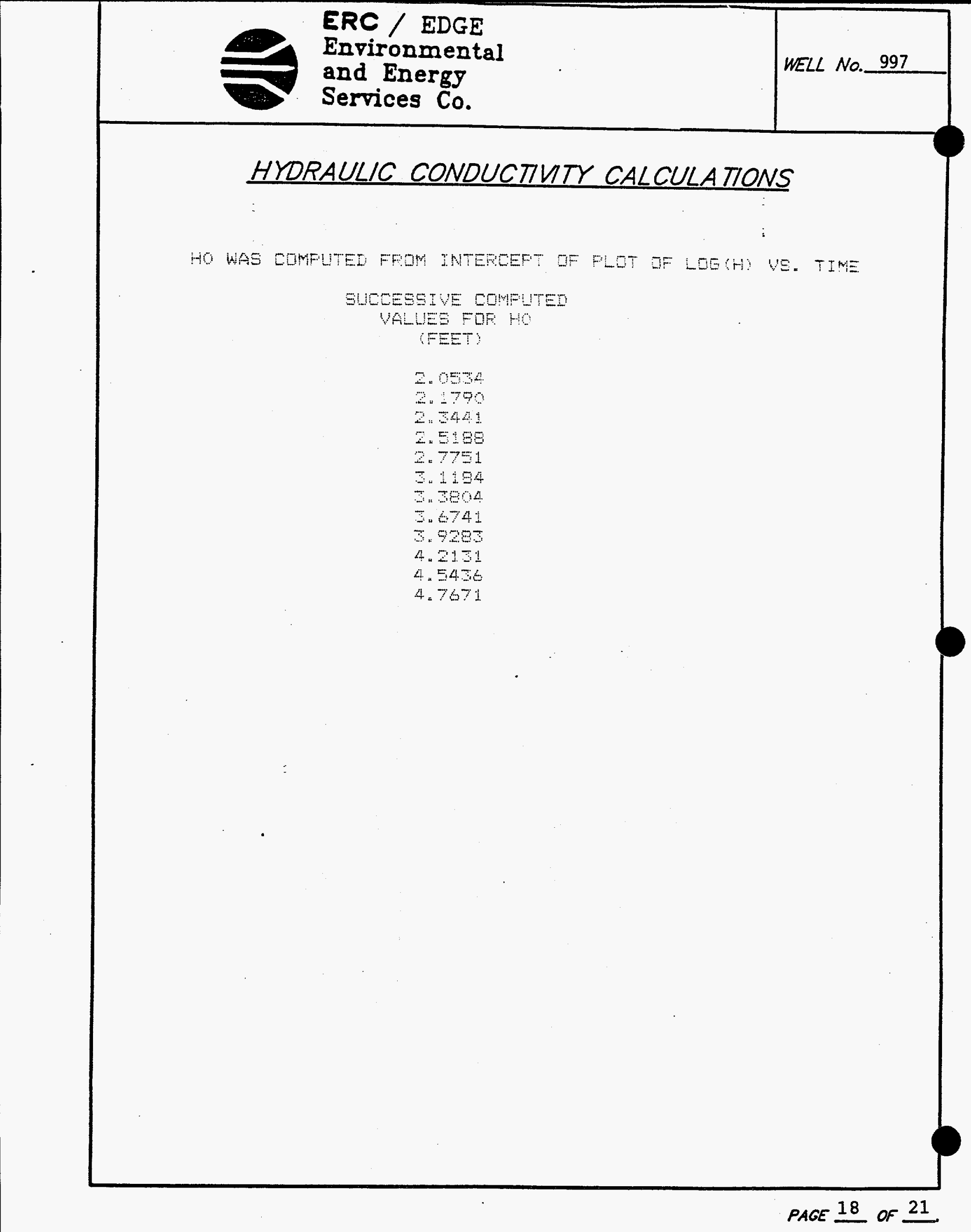




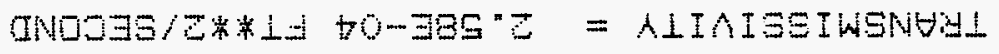

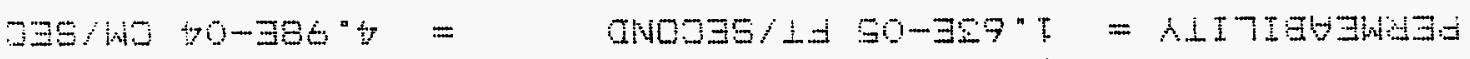

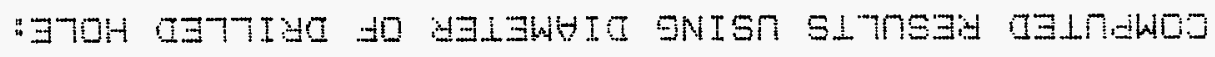

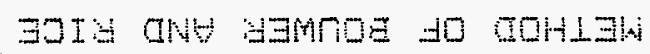

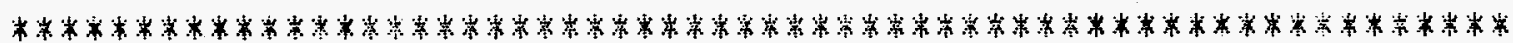

it

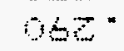

in

i

$\mathrm{0}$

$y$

or

99

)

1)

bs

न1"

$z^{2}$

E

OH:

क०

,

$\mathrm{Co}^{*}$

$7=$

40

गา"

0

9. "

$-3 \pm$

Ibin

SNOUV7กJ7VJ
$0 \angle y^{\circ}$

6

iLE"

in

it?

- 4

it

$0 \%$

)

TiE

6"

in

$-7=$

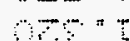

OLF"

37

$\mathrm{BO}$

बत:

-

$39^{\circ}$

ดा"

4

$\mathrm{se}^{\circ}$

$1=5$

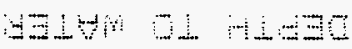

)

क लड

(1) "19:

की "Oि.

की

)

"i) ${ }^{x} \mathrm{a}$ !

औक "न

$0=0$

\%

बी $=2$

009

की $=$

ओल

$00 \cdot 3$

की "ो

की 5

00 "

ओ"

बा

बी"

ओं

$10 " 3$

MONG;

ZNI

- os sootados $\triangle 8$ IaUt pur

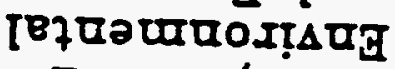
BDवG / ox3

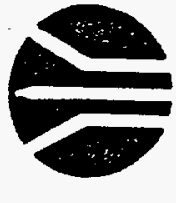


ERC / EDGE

Environmental

and Bnery

Services Co.

\section{HYDRAULUC CONDUCTUTY CALCULATONS}

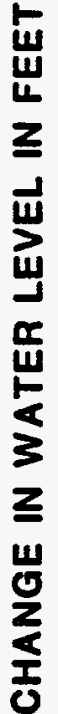

10.3

80.

7.0

6.0.

5.0

4.0

3.0

$=$

$+1$

1
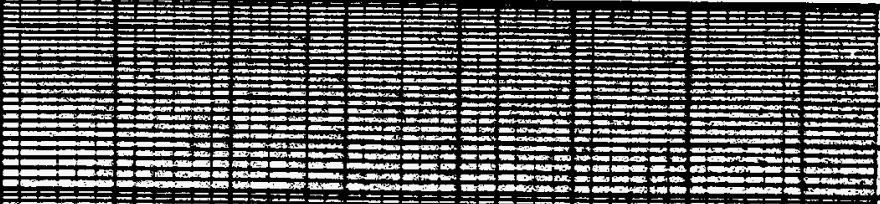

11

$1 . 5 \longdiv { \square }$

$1.0 \mathrm{H}+\mathrm{H}$

II) 0.9

$2 \quad 0.8$

0.2

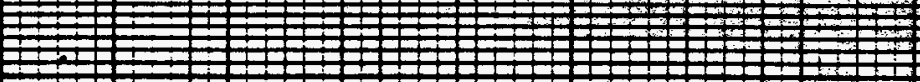

10

0.5

0.4

0.3

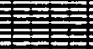

7

$+1$

0.9

0.08

0.07

0.06

0.05

0.04

0.03

0.02

W

\begin{tabular}{l} 
Y \\
\hline
\end{tabular}

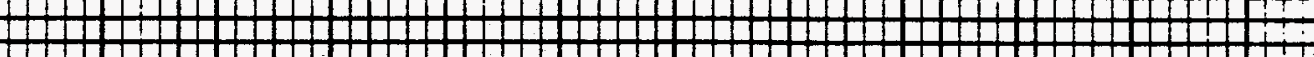

H

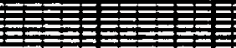
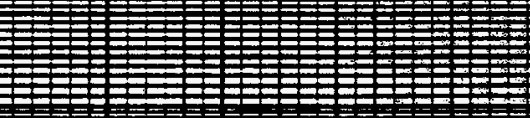

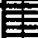

$+$

壮

以 உ円田

0.01 III

- 30SEC. I

2

3

4

$5 \mathrm{MIN}$.

TIME IN MINUTES 


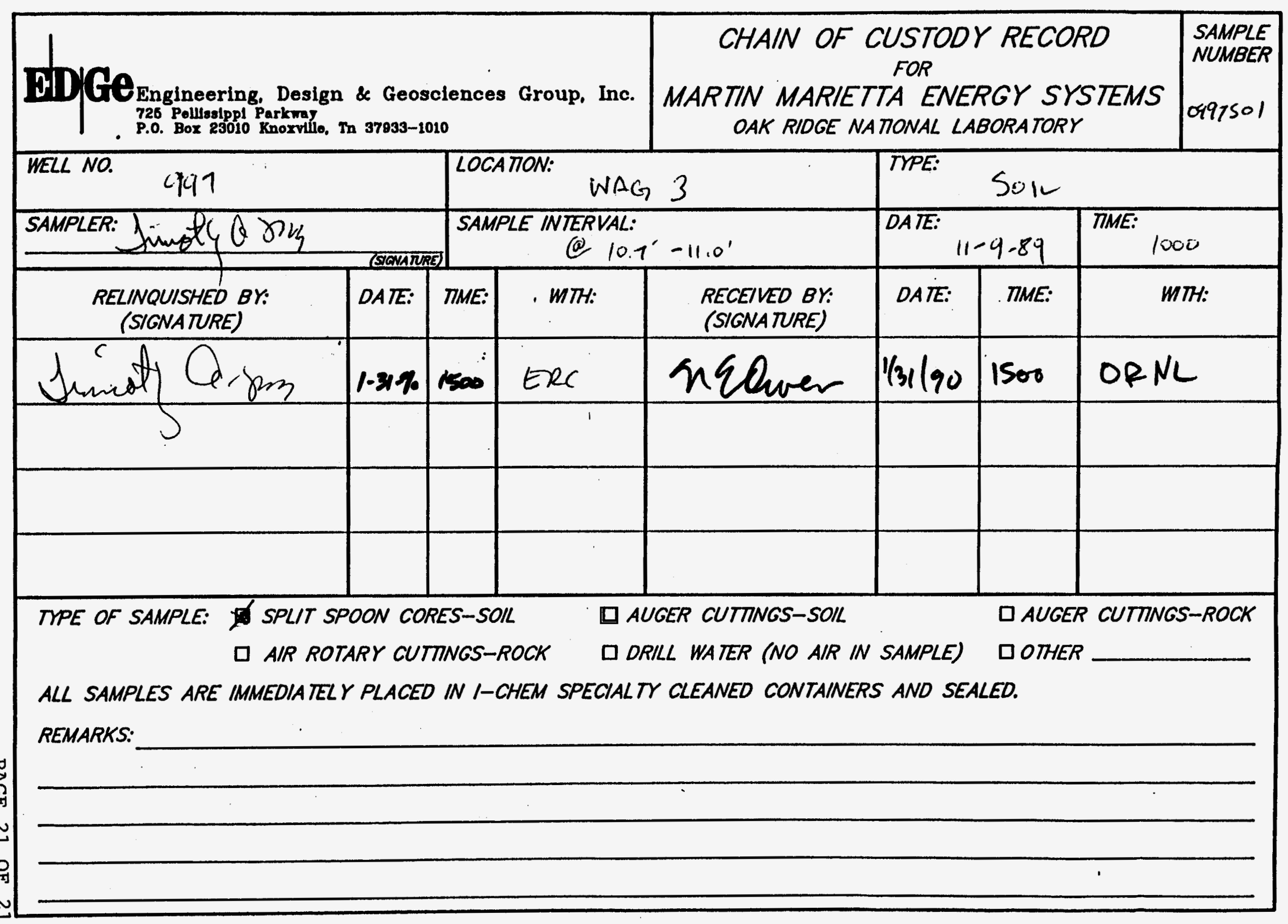




\subsection{Nell Location}

Monitoring well number 998 is located in WAG 3 . It is located 450 feet south of the SWSA 3 boundary fence. The location is shown on ORNI drawing number C3E20004 A075. Survey coordinates for this well are N 20,984.5939, E26,235.9355 (X-10 grid) or latitude $35^{\circ}-55^{\prime}-00.82^{\prime \prime}$ and longitude $84^{\circ}-19^{\prime}-42.35^{\prime \prime}$. Coordinate data were provided by Martin Marietta Energy Systems. The method used for conversion from X-10 grid to Tennessee-Lambert State Plane Coordinates came from the publication "Tennessee Valley Authority Data Services Branch and Mapping Services Branch, Oak Ridge, Tennessee, DOE Plant Control, November 6, 1985, Field Book: ESS-3115, pp. 1-20." The latitude and longitude were calculated by Adams Craft Herz Walker Engineering, Inc., using methods from the U.S. Coast and Geodetic Survey Publication 62-4, "State Plane Coordinates by Automatic Data Processing."

\subsection{Drilling Information}

Well number 998 was drilled by A. L. Clark Drilling Services. A Schramm Rotadrill rig was used to drill this boring for monitor well installation under operation of Richard Pickel with the assistance of Leo Johnson. Drilling commenced on 9-23-87 and was finished on 9-25-87. Paragraph 2.4.1 includes a detailed discussion of the well installation and a well schematic is included on the well installation/ completion form. A synopsis of the drilling activity 
follows. This information was typed directly from field notes and was edited only when necessary for clarification.

9-23-87 The Schramm Rotadrill was steamcleaned and mobilized to the staked location and set up. The boring was split spooned from 0.0 feet to 8.0 feet and augered from 0.0 feet to 12.0 feet with a $61 / 4$-inch auger.

9-24-87 Deepened boring from 12.0 feet to 20.0 feet with a 6 1/4-inch auger. Bailed hole, had 10 to 12 feet of water in boring.

9-25-87 Boring was bailed and well was set with 2inch stainless steel screen and casing. A sandpack and bentonite seal were installed.

This well was logged by ERC Environmental and Energy Services Co., Inc., hydrogeologists Daniel c. Baughn and Michael L. Ebers. All well construction materials and supplies were from Martin Marietta Energy Systems approved batches. The batch origin of individual items is shown on the included Monitoring Well Materials Certification form.

\subsection{Technical Information}

\subsection{Decontamination Procedures}

The drilling rig, down hole tools, surface casing, stainless steel screen, stainless steel casing, centralizers, and stainless steel silt trap underwent the cleaning decontamination procedures outlined in 
the drilling specifications (Release specific Technical Directions for Regulatory Compliance Monitoring Wells Phase 1, Oak Ridge National Laboratory, Oak Ridge, w.0. K-4147, April 1987, pgs. 2-4). A checklist of the cleaned materials is included with this data package.

\subsection{Geology}

WAG 3 is located in Melton Valley which is in the Valley and Ridge Physiographic Province of East Tennessee. WAG 3 is underlain by limestone, siltstone and shale of the Middle Ordovician Chickamauga Group. The Chickamauga Group consists of eight units, designated by letters "A" to "H" (Stockdale, 1951). WAG 3 is underlain by units $E, F, G$ and $H$. These units consist of thin bedded nodular limestone with clay and shale partings. A portion of unit $H$ and unit F consists of calcareous siltstone alternating with beds of olive gray to maroon shale. Strike and dip varies from $\mathrm{N} 45^{\circ} \mathrm{E}$ to $\mathrm{N} 55^{\circ} \mathrm{E}$ and $25^{\circ}$ to $35^{\circ}$ southeast, respectively.

\subsection{Bample collection}

Two soil samples were collected during drilling, placed in I-CHEM specialty cleaned glass containers, sealed and submitted to Sample Receiving, Analytical Chemistry Division, Bldg. 4500S, ORNL. Chain of custody forms for these samples are included with this data package. Soil sample 998502 was collected in the split spoon interval from 3.1 feet to 3.2 feet on 


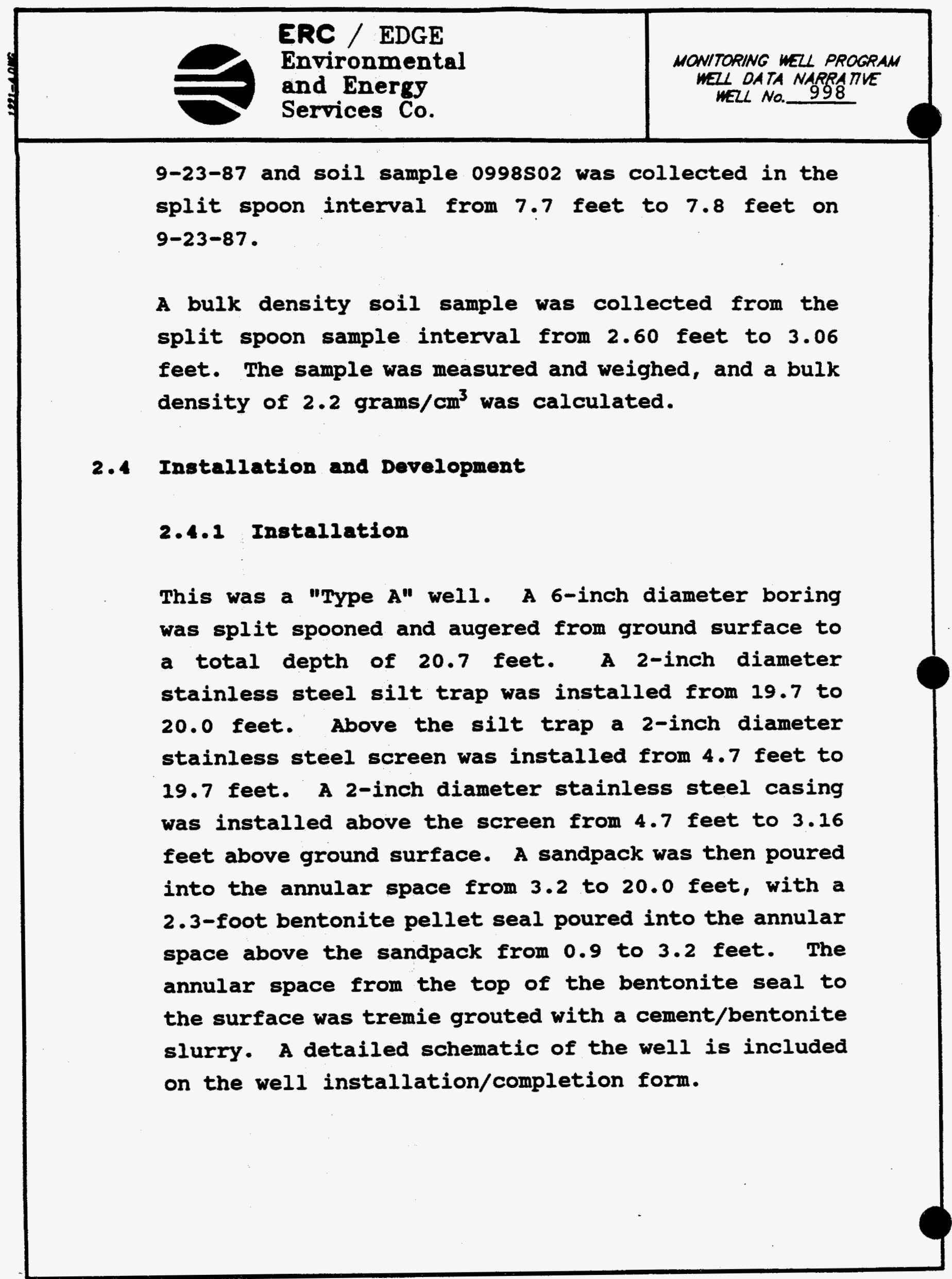


Well Development

Well number 998 was developed to remove drill cuttings, silt, and other fines. The monitoring well was developed using a Geoguard pump with an air compressor. All pumps were cleaned prior to use according to specified cleaning procedures (see Paragraph 2.1). The well was developed until a measured total of 311 gallons of water had been evacuated and the clarity of the discharge water was approved by the company representative. The final turbidity value measured at completion was 3.0 NTU's. A development form showing the exact method of development and other pertinent data is appended.

\subsubsection{Installation of Dedicated Monitoring well Punp}

After the well was developed, a Geoguard Model No. 5614 dedicated monitoring well pump was installed on 4-23-90 at a depth of 17.8 feet below ground surface. These pumps are decontaminated at American Sigma and are sent prepackaged. A copy of the pump certification is kept on file at ORNL.

\subsection{Hydraulic conductivity resting}

Well number 998 was tested for the determination of hydraulic conductivity of the aquifer in the vicinity of the well screen. This was accomplished by instantaneously adding a known quantity of water to the monitoring well and measuring the recovery of the water level over time. The changing water levels were 
measured using a Druck 15 psig pressure transducer and an Omnidata Datapod II data recorder. The hydraulic conductivity value of $9.39 \times 10^{-5} \mathrm{~cm} / \mathrm{second}$ (shown as permeability on the hydraulic conductivity calculations printout attached) was calculated using the Bouwer and Rice method. A computer printout of the hydraulic conductivity calculations is included in this data package. 


\section{PRE-DRILLING CHECKLIST FOR MONITORING WELLS}

\section{PRE-DRILLING TASKS}

1. EXCAVATON PERMIT OBTAINED.

2. ALL EQUIPNENT HAS BEEN CLEANED BEFORE DRILING.

3o. SCREEN AND CASINGS HAVE BEEN WASHED, STEAMED, RINSED WTH DE-IONIZED OR OISTLLED WATER, RINSED WTH ISOPROPY ALCOHOL MRAPPED WTH PROTECTVE COVERING AND STORED OFF THE CROUND.

36. PRE-PACKAGED SCREENS CASINGS ANO CENTRALIZERS MERE USED.

4. WORK AREA FOR SAMPLE EXAMINATION COVERED WIH CLEAN POL RETHRENE.

5. CLEAN KNIES, GOVES, SAMPLE JARS AND LABELS ON-HAND.

6. POLETHRENE COVRR IN PLACE OVER HOLE. COMPLIANCE DAIE INITALS 9-23-87 NLE 9-23-87 ME $N / A$

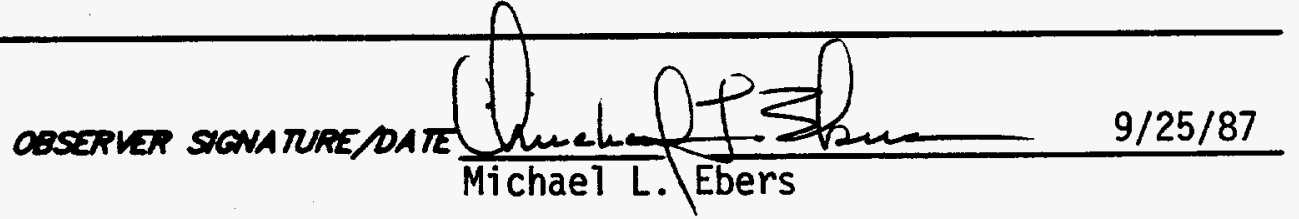




\section{DECONTAMINATION CHECKLIST \\ DRILLING EQUIPMENT}

\begin{tabular}{|c|c|c|c|c|c|}
\hline EQUIPMENT & SCRAPE & $\begin{array}{l}\text { STEN } \\
\text { CLEAN }\end{array}$ & $\begin{array}{l}\text { STEAN } \\
\text { RINSE }\end{array}$ & $\begin{array}{c}\text { ISOPROPL } \\
\text { ALCOHOL } \\
\text { RINSE }\end{array}$ & $\begin{array}{c}\text { OEIONIZED } \\
\text { WATER } \\
\text { RINSE }\end{array}$ \\
\hline$R / G$ & $x$ & $x$ & $x$ & $N / A$ & $N / A$ \\
\hline AUGERS & $x$ & $x$ & $x$ & $x$ & $x$ \\
\hline BITS & $x$ & $x$ & $x$ & $x$ & $x$ \\
\hline ROOS & $x$ & $x$ & $x$ & $x$ & $x$ \\
\hline SAMPLERS & $x$ & $x$ & $x$ & $x$ & $x$ \\
\hline PIPES & $x$ & $x$ & $x$ & $x$ & $x$ \\
\hline WORK TOOLS & $x$ & $x$ & $x$ & $x$ & $x$ \\
\hline AUGER PINS & $x$ & $x$ & $x$ & $x$ & $x$ \\
\hline & & & & & \\
\hline & & & & & \\
\hline & & & & & \\
\hline & & & & & \\
\hline
\end{tabular}

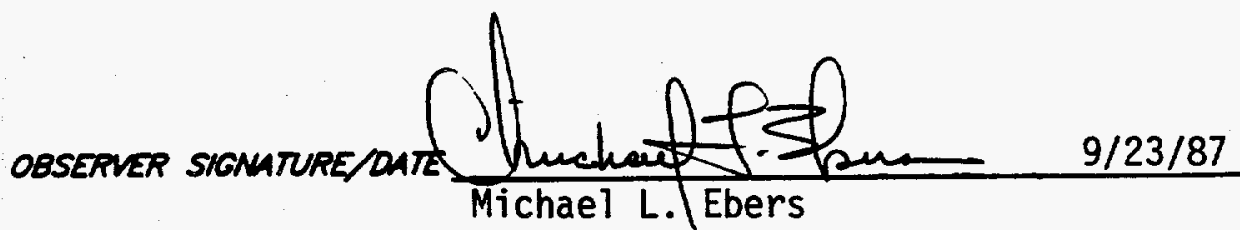




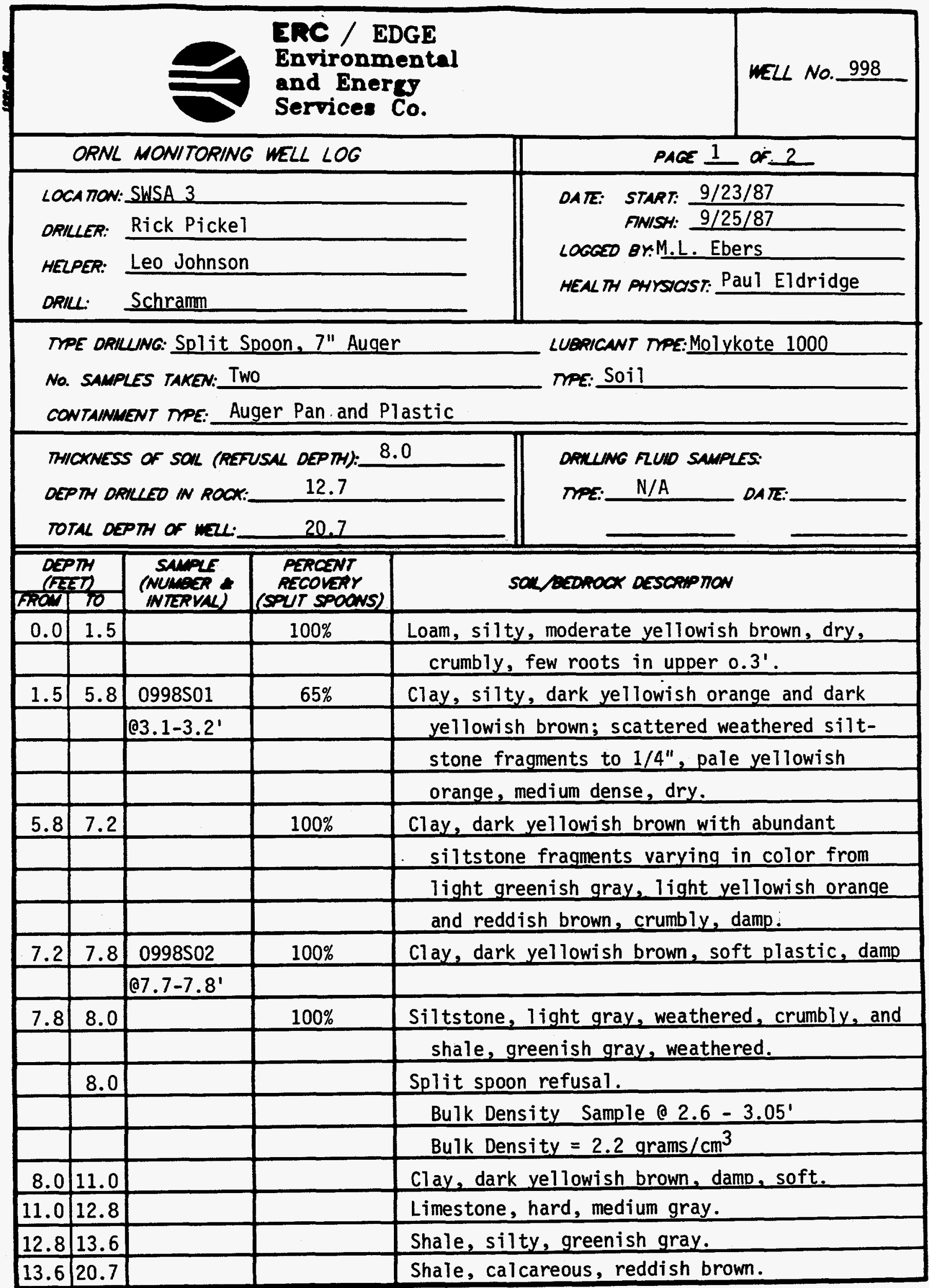




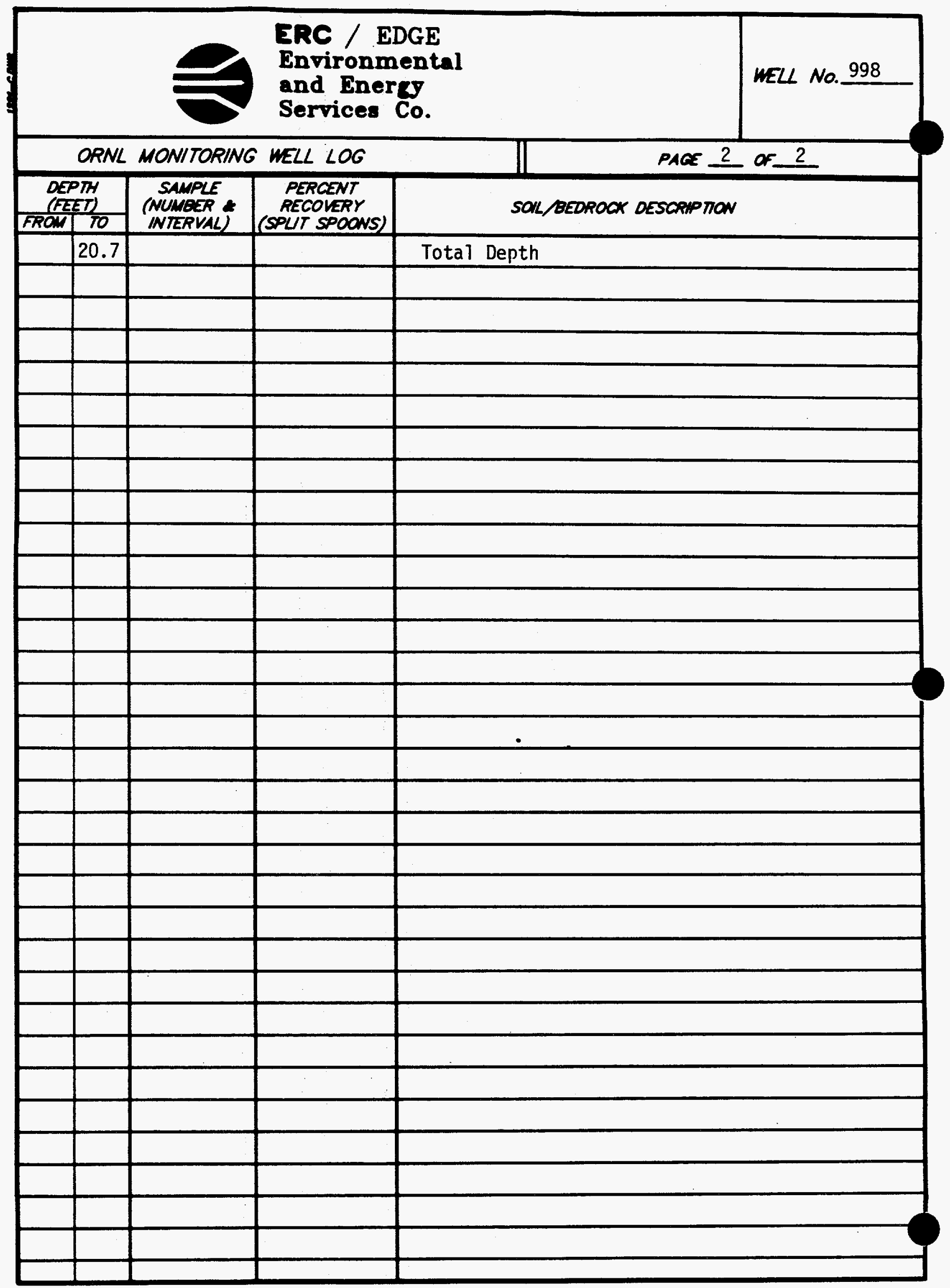

PAGE 10 or 20. 


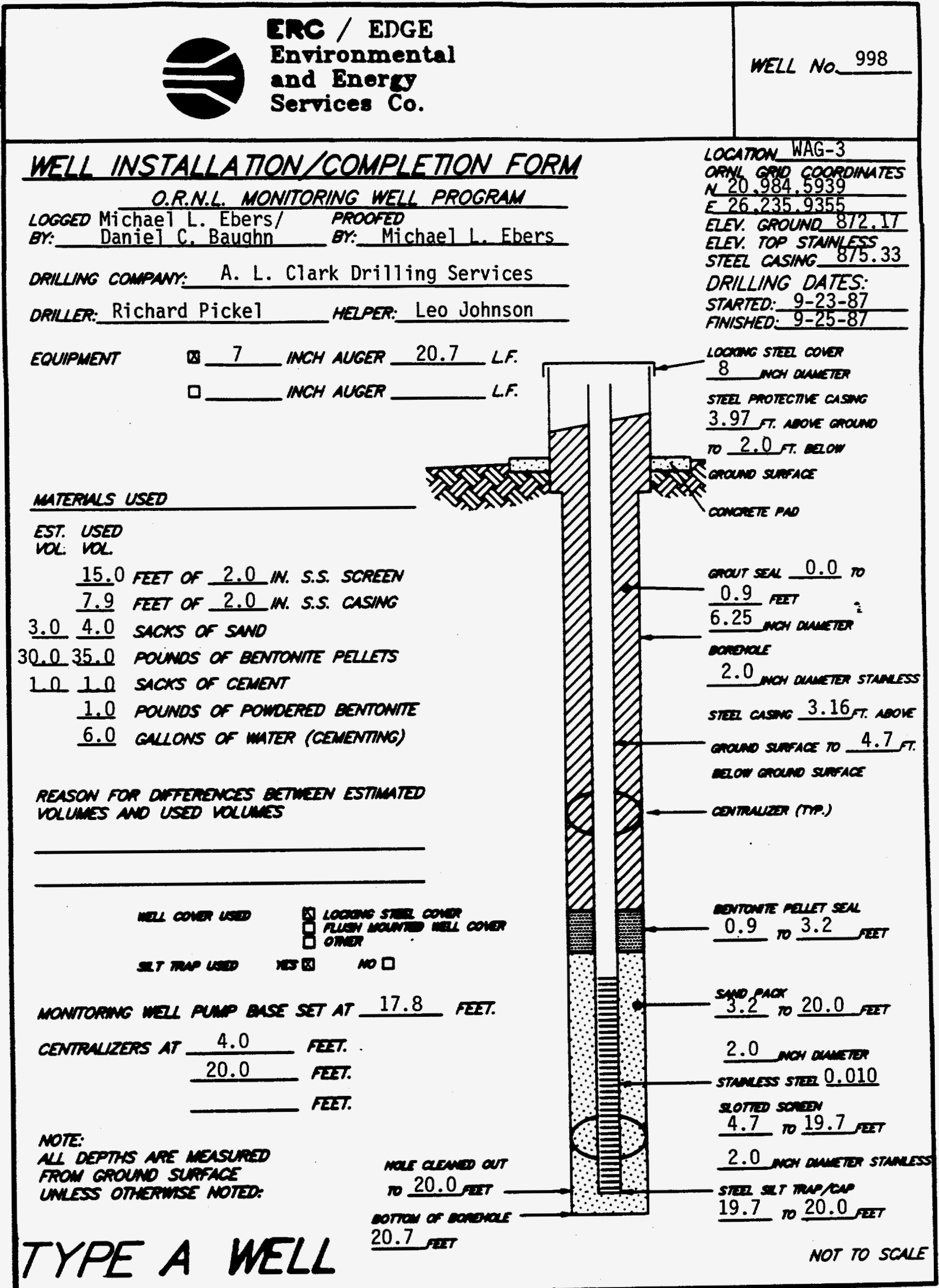

Pree 11 of 20 . 


\section{MONITORING WELL MATERIALS CERTIFICATION}

\begin{tabular}{|c|c|c|}
\hline ITEM/MA TERIAL & DATE USED & BATCH NUMBER \\
\hline SAND & $9 / 25 / 87$ & 2 \\
\hline BENTONITE & $9 / 25 / 87$ & 2 \\
\hline 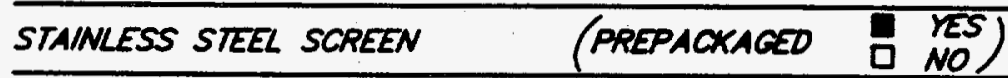 & $9 / 25 / 87$ & 5 \\
\hline STAINLESS STEEL CASING (PREPACKAGED $\quad$ YES & $9 / 25 / 87$ & 5 \\
\hline STAINLESS STEEL CENTRALIZERS (PREPACKAGED D YES) & $9 / 25 / 87$ & 5 \\
\hline (PREPACKAGED OQ YES) & $9 / 25 / 87$ & 5 \\
\hline MONITORING WELL PUMP (PREPACKAGED 1 YES & $4 / 23 / 90$ & 5 \\
\hline \multirow{2}{*}{ GROUT } & $9 / 26 / 87$ & \\
\hline & $12 / 87$ & 15 \\
\hline MELL COVERS & & 1 \\
\hline SURFACE CASING & $12 / 87$ & 2 \\
\hline
\end{tabular}

COMMENTS:

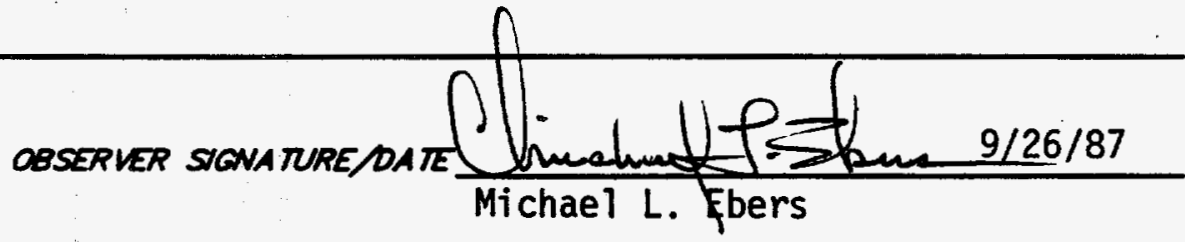

PAGE 12 or 20 . 
ERC / EDGE

Environmental

and Eneres

WELL NO. 998

Services Co.

\section{POST-MELL COMPLETION CHECKLIST}

\section{POST-MELL COMPLETION TASKS}

COMPLIANCE

DATE INITALS

1. WUO SCRAPED FROW AUERRS SAMPLERS ANO ALL OTHER EQUPPEENT.

2. ALL NUD FROW RIG AND EQUMPMENT SCRAPINGS ANO CUTINGS DISPOSED OF IN ACCORDANCE WTH THE SPECATCA ION PROVDED.

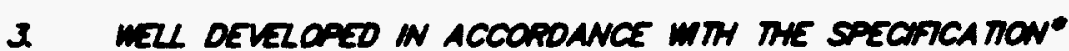
PROVDED AND DETAKS OF THE DETEZOPWENT ACIVTH RECOROED.

4. DRULNG STE PROPERLY CLEANED UP AFTER COMPLETION OF WIL INSTALLATON.
9/25/87 per

9/25/87 MUe

4/23/90 DCL

$9 / 25 / 87$

UUE

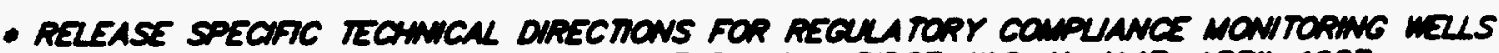
PHASE b OAK RWOE NAMONAL LABORATORY, OAK RDOE, W. K-4147, APRK 1987.

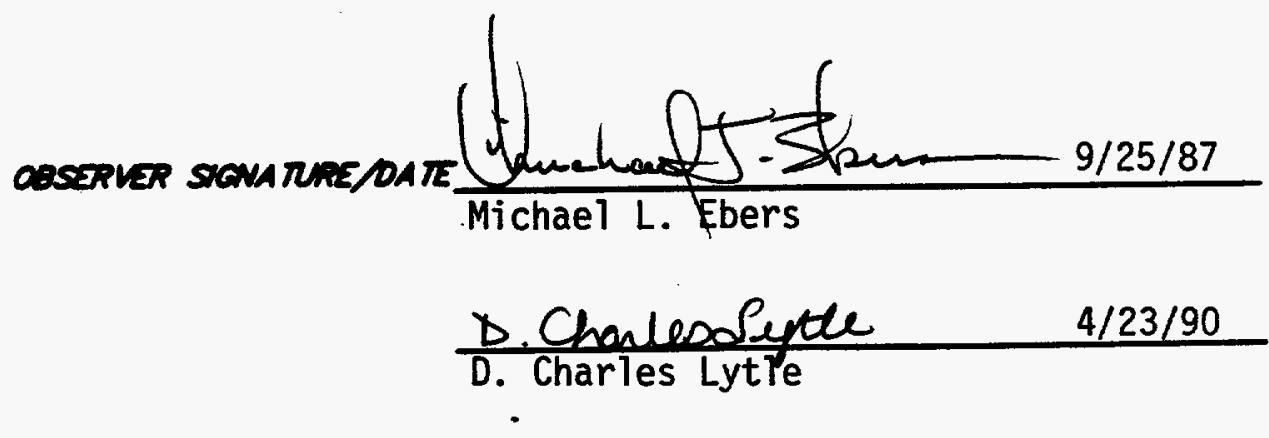




\section{MONITORING WELL \\ DEVELOPMENT FORM}

DEVELOPMENT DETAILS

METHOD OF

DEVELOPMENT: Surging and Pumping

DEVELOPMENT

BEGAN DATE:

$4 / 19 / 90$

TME:

DEVELOPMENT

ENDING DATE: $\quad 4 / 23 / 90$

DEVELOPMENT: D. Charles Lytle
OBSERVED BY:

ONE WELL VOLUNE: 10.0 GALLONS

TOTAL GALLONS PUMPED: 311 TOTAL WELL VOLUMES PUMPED:-31.1

NITAL PH: 7.7 FNAL PH: 7.7

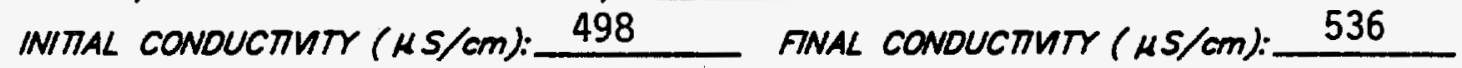

OESCRIPTION OF INITAL TURBIDITY: Slightly Cloudy

OESCRIPTION OF FINAL RURBIDITY: Clear

FINAL MEASURED TUREIOITY.

3.0 NTU's

WELL APPROVED BY:

R. C. Williams MMES

ODOR

OF WATER: None

WA TER

DISCHARGED

TO:

$\triangle$ GROUNO SURFACE

D STORM SEWERS

D DRUNS
ㅁ TANK TRUCK

STORAGE TANKS

D OTHER

INITAL PRE-DEVELOPMENT

WATER DEPTH:

$+.2^{\prime \prime}$ above ground surface.

DEVELOPMENT OBSERVATIONS

OBSERVER SIGNATURE/DATE D.Chonles olyele 4/23/90

D. Charles Lytle 


\section{MONITORING WELL DEVELOPMENT PROGRESS}

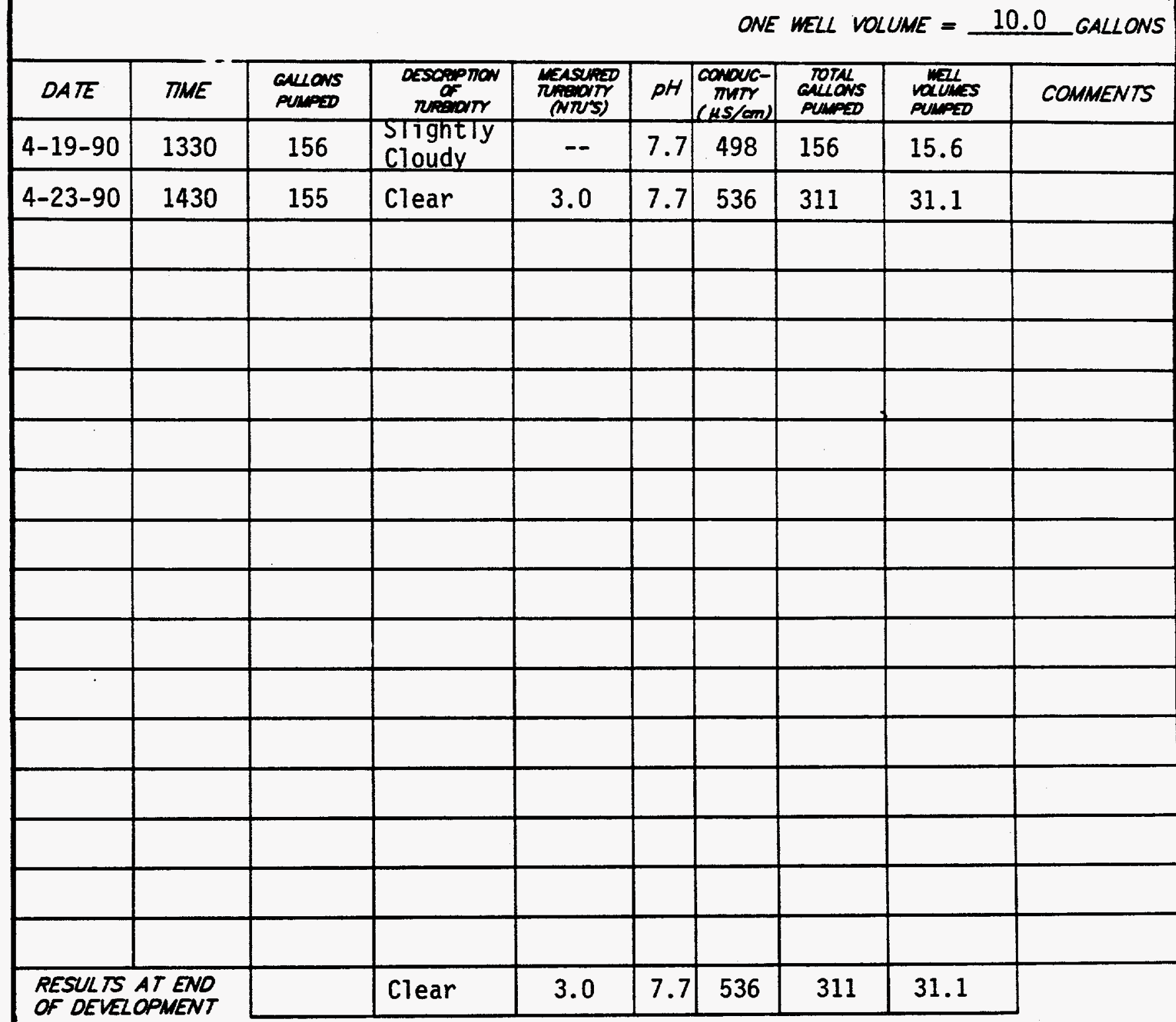

COMMENTS Nice producer. Cleared fast and remained clear even after several cycles after surging. Passed and moved off of hole. 


\section{HYDRAULIC CONDUCTIVTY CALCULATIONS}

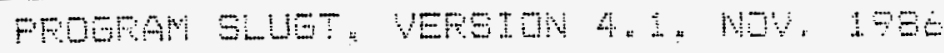

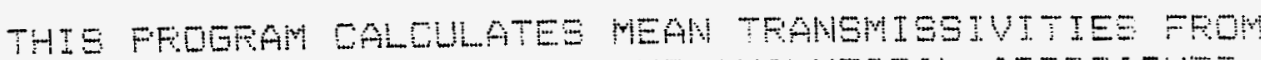

GLUG-TEST DATA EASED DN TWO ANALYTICAL AFPOCACHES:

(1) METHOD OF DOPEE, EREDEHOEFT AND PAPADOFULOS 1967

IAFTICLE IN VOL 3 . NOI OF WPE ENTTLED

"RESFONGE OF A FTMTE DTANETEF WEL TO AN INOTANTANEOUS

DHAFEE DF WATEE:

2 METHOD OF PUUWE AND EICE, $197 \mathrm{~A}$ ARTISE IN

VOL 12, MO: OF ARF ENTETLED

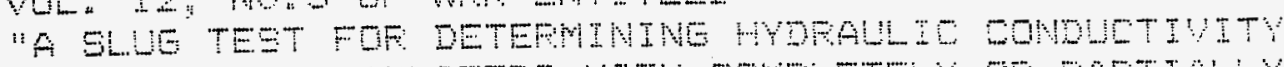

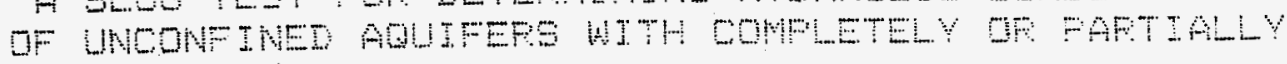

PENETRATTNE WELIS:

WEL NE: 99

DATE OF TEST: $51 \mathrm{AOO}$

FrOTEOT NO: E22-01

DIENT: WES

BITE LOCATIOH: XIO

EDGE, INE. FIELD INUESTIGATOE ERUCE MEMASTEE

INFUT DATA ARE:

INUEN CASTNG DIAMETEF $=2.00$ TNCHES

INUER SCREEN OF QFEN-HOLE DIANETEF $=2.00$ INCHES

DIAMETER OF DFILLED HOLE = 6.25 INCHES

LENGTH OF SLREEN OF INTAKE FOFTION = $15.0 \mathrm{FEET}$

DEPTH FFOM STATIC LEVEL TO EOTTOM OF SOREEM = 14.20 FEET

THICWNESS OF SATUFATED AQUTFEF ZONE = 15.00 FEET

DEFTH TO STATIC WATEF LEVEL BELOW FEF. FOLNT = "BS FEET

ESTTMATED PORDEITY OF ERAVEL FACK = 30

FALLING-HEAD INDEX $=$ I. "IF FALLINE "O" IF FISINE?

NUMEE OF DEFTH-TINE DATA FOINTS $=22$

HO WAS COMFUTED FROM INTEFCEFT OF FLOT OF LOE HH US. TINE

SUCCESSIVE CDMFUTED

VALUES FOF HO

(FEET)

1.6417

1. 7098 


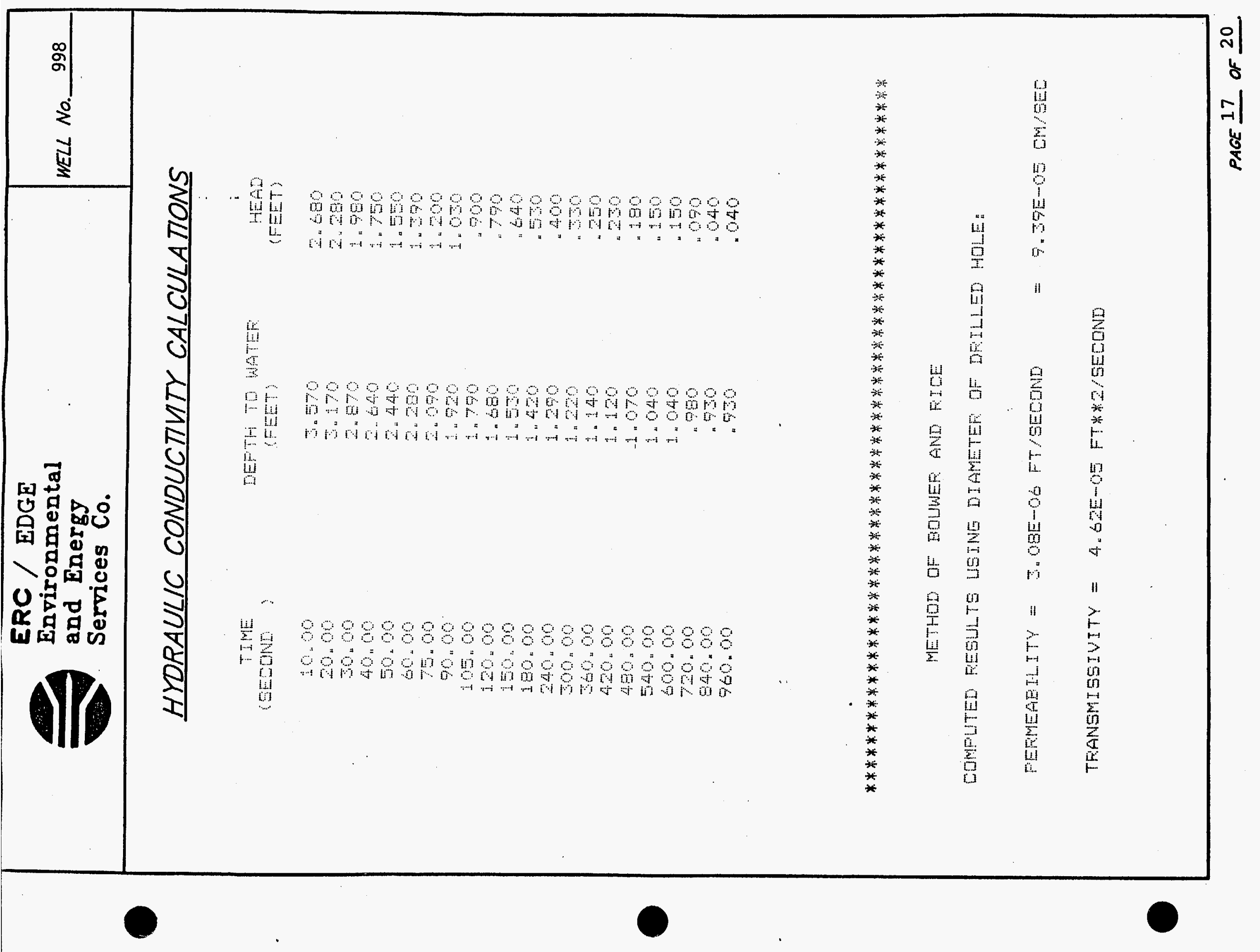




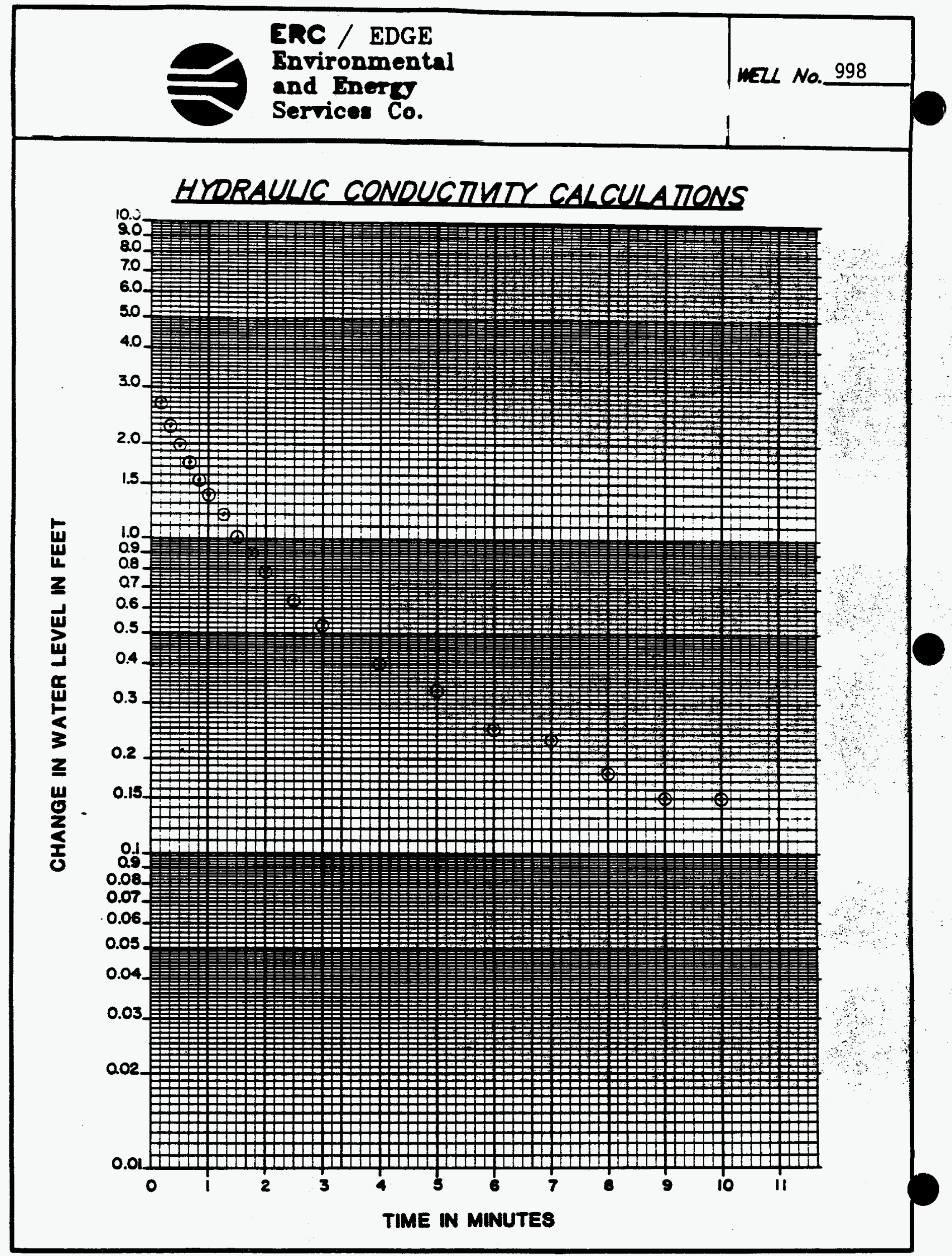

PAC 18 of 20 
MCI/CONSULTING ENGINEERS, INC. NASHVILLE KNOXVILLE HUNTSVILLE LOUISVILLE (6I5) $966-9788$

WELL NO.:

SAMPLER:

RELINQUISHED BY: (SIGNATURE)

Vhehante Etsms (

\section{CHAIN OF CUSTODY RECORD FOR} MARTIN MARIETTA ENERGY SYSTEMS OAK RIDGE NATIONAL LABORATORY LOCATION: : SWSA 3

$3.1^{\prime}$ To $3.2^{\prime}$

\begin{tabular}{l|l} 
SWSA 3 & TYPE: SOIL
\end{tabular}
SAMPLE NUMBER:

0998 sol

\begin{tabular}{|c|c|c|c|}
\cline { 2 - 4 } & \multicolumn{2}{|c|}{ DATE: $9 / 23 / 87$} & TIME: \\
\hline $\begin{array}{c}\text { RECIEVED BY: } \\
\text { (SIGNATURE) }\end{array}$ & DATE: & TIME: & WTH: \\
\hline Mancy Quen & $10 / 20 / 87$ & $9: 45$ & ORNL \\
\hline & & & \\
\hline & & & \\
\hline & & & \\
\hline
\end{tabular}

REMARKS:

\begin{tabular}{|c|c|c|c}
\hline DATE: & TIME: & WITH: & $\begin{array}{r}\text { RECIEVED BY: } \\
\text { (SIGNATURE) }\end{array}$ \\
\hline $10 \% 0 / 67$ & $9.45 A M$ & MCI & Mancy Quen \\
\hline & & & \\
\hline & & & \\
\hline
\end{tabular}


MCIICONSULTING ENGINEERS, INC. NASHVILLE KNOXVILLE HUNTSVILLE LOUISVILLE (615) 966-9788

WELL NO.: 998

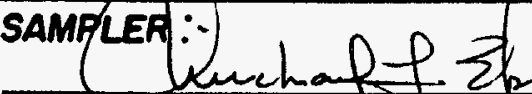
RELINQUISHED BY: (SIGNATURE)

\begin{tabular}{|l|l|l|}
\hline (SIGNATURE) & DATE: & TIME: \\
\hline & $10 / 20 / 87$ & $9.45 \mathrm{AN}$ \\
\hline & & \\
\hline & & \\
\hline & & \\
\hline
\end{tabular}

REMARKS:

\section{CHAIN OF CUSTODY RECORD FOR MARTIN MARIETTA ENERGY SYSTEMS} OAK RIDGE NATIONAL LABORATORY
SAMPLE

NUMBER:

998 Soz
LOCATION: : SWSA 3

$7.7^{\prime}$ To $7.8^{\prime}$
TYPE:

$50 / 2$

DATE:

$9 / 23 / 87$

TIME:

4:30 P.M.

WITH:

RECIEVED BY:

(SIGNATURE)

$M C I$

\begin{tabular}{l|l|l|l}
\hline Plavey Quen & DATE: & TIME: & WTH: \\
\hline 10/20/87 & I:KS & ORNL
\end{tabular}




\subsection{General Information}

\subsection{Well Location}

Monitoring well number 1247 is located in WAG 3 . It is located on the western boundary of WAG 3 adjacent to Highway 95.

The location is shown on ORNL drawing number C3E20004 A075. Survey coordinates for this well are N 21,357.5769, E 24,659.5516 (X-10 grid) or latitude $35^{\circ}-54^{\prime}-55.21^{\prime \prime}$ and longitude $84^{\circ}-20^{\prime}-00.79^{\prime \prime}$. Coordinate data were provided by Martin Marietta Energy Systems. The method used for conversion from $\mathrm{X}-10$ grid to Tennessee-Lambert State Plane Coordinates came from the publication "Tennessee Valley Authority Data Services Branch and Mapping Services Branch, Oak Ridge, Tennessee, DOE Plant Control, November 6, 1985, Field Book: ESS-3115, pp. 1-20." The latitude and longitude were calculated by Adams Craft Herz Walker Engineering, Inc., using methods from the U.S. Coast and Geodetic Survey Publication 62-4, "State Plane Coordinates by Automatic Data Processing."

\subsection{Drilling Information}

Well number 1247 was drilled by Geotek Engineering company. An Ingersoll-Rand rig was used to drill this boring for monitor well installation under operation of Larry Ledbetter with the assistance of Fred Dixon. Drilling commenced on 5-22-90 and was finished on 5-25-90. Paragraph 2.4.1 includes a detailed discussion of the well installation and $a$ well 
ERC / EDGE

Environmental

and Energy

Services Co.

MONITORING WELL PROGRAM

WELL DATA NARRATVE

WELL No. 1247

schematic is included on the well installation/ completion form. A synopsis of the drilling activity follow. This information was typed directly from field notes and was edited only when necessary for clarification.

5-22-90 Moved site to location and set up on plastic sheeting. Augered from surface to 6.0 feet using a 14-inch auger. Set and grouted 10-inch decontaminated steel diverter casing.

5-24-90 Drill to 22.7 feet using an 8-inch air rotary tricone bit into containment box.

5-25-90 set 2-inch stainless steel screen and casing with sandpack and bentonite seal. Grout annulus with 1.5 sacks cement.

This well was logged by ERC Environmental and Energy Services Co., Inc., hydrogeologist Timothy A. Lee. All well construction materials and supplies were from Martin Marietta Energy Systems approved batches. The batch origin of individual items is shown on the included Monitoring Well Materials Certification form.

\subsection{Technical Information}

\subsection{Decontamination Procedures}

The drilling rig, down hole tools, surface casing, stainless steel screen, stainless steel casing, centralizers, and stainless steel silt trap underwent the cleaning decontamination procedures outlined in the drilling specifications (Release specific 
ERC / EDGE

Environmental

MONITORING WELL PROGRAM

and Energy

Services Co.

Technical Directions for Regulatory Compliance Monitoring Wells Phase 1, Oak Ridge National Laboratory, Oak Ridge, w.0. K-4147, April 1987, pgs. 2-4). A checklist of the cleaned materials is included with this data package.

\subsection{Ceology}

WAG 3 is located in Melton Valley which is in the Valley and Ridge Physiographic Province of East Tennessee. WAG 3 is underlain by limestone, siltstone and shale of the Middle ordovician Chickamauga Group. The Chickamauga Group consists of eight units, designated by letters "A" to "H" (Stockdale, 1951). WAG 3 is underlain by units E, F, G and H. These units consist of thin bedded nodular limestone with clay and shale partings. A portion of unit $H$ and unit $F$ consists of calcareous siltstone alternating with beds of olive gray to maroon shale. Strike and dip varies from $\mathrm{N} 45^{\circ} \mathrm{E}$ to $\mathrm{N} 55^{\circ} \mathrm{E}$ and $25^{\circ}$ to $35^{\circ}$ southeast, respectively.

\subsection{Bample collection}

No samples were collected during drilling.

The Ingersol1-Rand T-4 compressed air was sampled with a cloth filter inserted between drill rods on 5-29-90. The sample was examined with an ultraviolet light for the pressure of hydrocarbons. The filter showed no detectable signs of hydrocarbons. 


\subsection{Installation and Development}

\subsubsection{Installation}

This was a "Type D" well. The air rotary method was required to complete the boring to the specified total well depth. Therefore, a 14.0-inch diameter boring was augered from ground surface to 6.0 feet and a 10inch diverter casing was installed and grouted. An 8inch diameter boring was then drilled with an air rotary tricone roller bit from 6.0 to 22.7 feet. A 2inch diameter stainless steel screen with threaded bottom cap was installed from 7.5 to 22.7 feet. A 2inch diameter stainless steel casing was installed above the screen at 7.5 feet and extended 2.15 feet above ground surface. A sandpack was then poured/ tremied into the annular space from 6.5 to 22.7 feet, with a 1.0-foot bentonite pellet seal poured into the annular space above the sandpack from 5.5 to 6.5 feet. The annular space from the top of the bentonite seal to the surface was tremie-grouted with a cement/ bentonite slurry. A detail of the well is included on the well installation/completion form.

\subsubsection{Ne11 Development}

Well number 1247 was developed to remove drill cuttings, silt, and other fines. The monitoring well was developed using a Geoguard pump with an air compressor. All pumps were cleaned prior to use according to specified cleaning procedures (see Paragraph 2.1). The well was developed until a measured total of 8 gallons of water had been 
evacuated. Well development was terminated due to the extremely poor well recharge rate. The final turbidity value measured at completion was $>100 \mathrm{NTU}$ 's. A development form showing the exact method of development and other pertinent data is appended.

\section{$2 \cdot 4 \cdot 3$}

Installation of Dedicated Monitoring well Pump

After the well was developed, a Geoguard Model No. 5614 dedicated monitoring well pump was installed on 8-23-90 at a depth of 21.6 feet below ground surface. These pumps are decontaminated at American sigma and are sent prepackaged. A copy of the pump certification is kept on file at ORNL.

\subsection{Hydraulic conductivity resting}

We11 number 1247 was tested for the determination of hydraulic conductivity of the aquifer in the vicinity of the well screen. This was accomplished by instantaneously adding a known quantity of water to the monitoring well and measuring the recovery of the water level over time. The changing water levels were measured using a Druck 15 psig pressure transducer and an Omnidata Datapod II data recorder. The hydraulic conductivity value of $5.59 \times 10^{-5} \mathrm{~cm} / \mathrm{second}$ (shown as permeability on the hydraulic conductivity calculations printout attached) was calculated using the Bouwer and Rice method. A computer printout of the hydraulic conductivity calculations is included in this data package. 


\section{PRE-DRILLING CHECKLIST FOR MONITORING WELLS}

PRE-DRILUNG TASKS

1. EXCAVTION PERMIT OBTAINED

2. ALL EQUIPMENT HAS BEEN CLEANED BEFORE DRILLING.

30. SCREEN AND CASING HAVE BEEN WASHED, STEAMED, RINSED WITH DE-IONIZED OR DISTILED WATER, RINSED WTH ISOPROPV ALCOHOL, WRAPPED WTH PROTECTVE COVERING AND STORED OFF THE GROUND.

36. PRE-PACKAGED SCREENS, CASING AND CENTRALIZERS MERE USED.

4. WORK AREA FOR SAMPLE EXAMINATION COVERED WITH CLEAN POL YETHRENE.

5. CLEAN KNIVES, GLOVES, SAMPLE JARS AND LABELS ON HAND.

6. POL YETHRENE COVER IN PLACE OVER HOLE.

7. AIR ROTARY COMPRESSED AIR SAMPLED.
COMPLIANCE

RAIE INIRALS

$5-22-90 \quad \frac{1025}{102}$

$5-22-90$

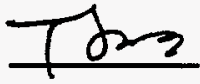

N/A

$5-25-90$

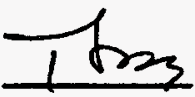

$5-22-90$

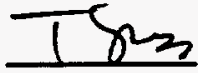

$5-22-90$

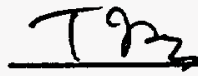

$5-24-90$

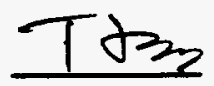

$5-24-90$

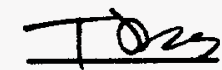

RESULTS: Sample showed no detectable signs of hydrocarbons under ultraviolet 1 ight.

ADOITONAL NOTES/OBSERVATIONS:

OBSERVER SGNATUREDATE $\frac{\text { Stmoty }}{\text { Timothy A. Lep }}$ 


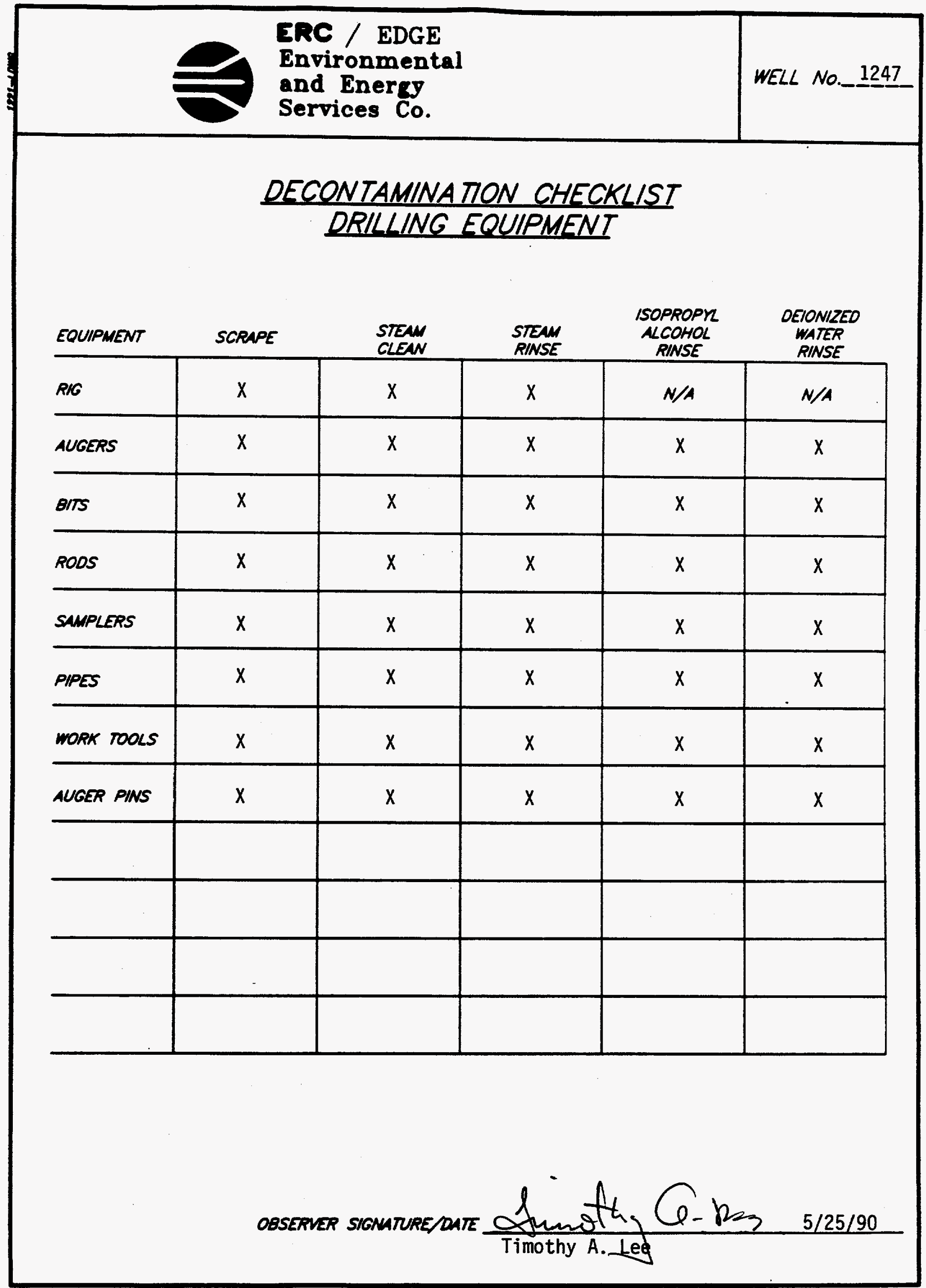

PAGE 7 OF 16 . 


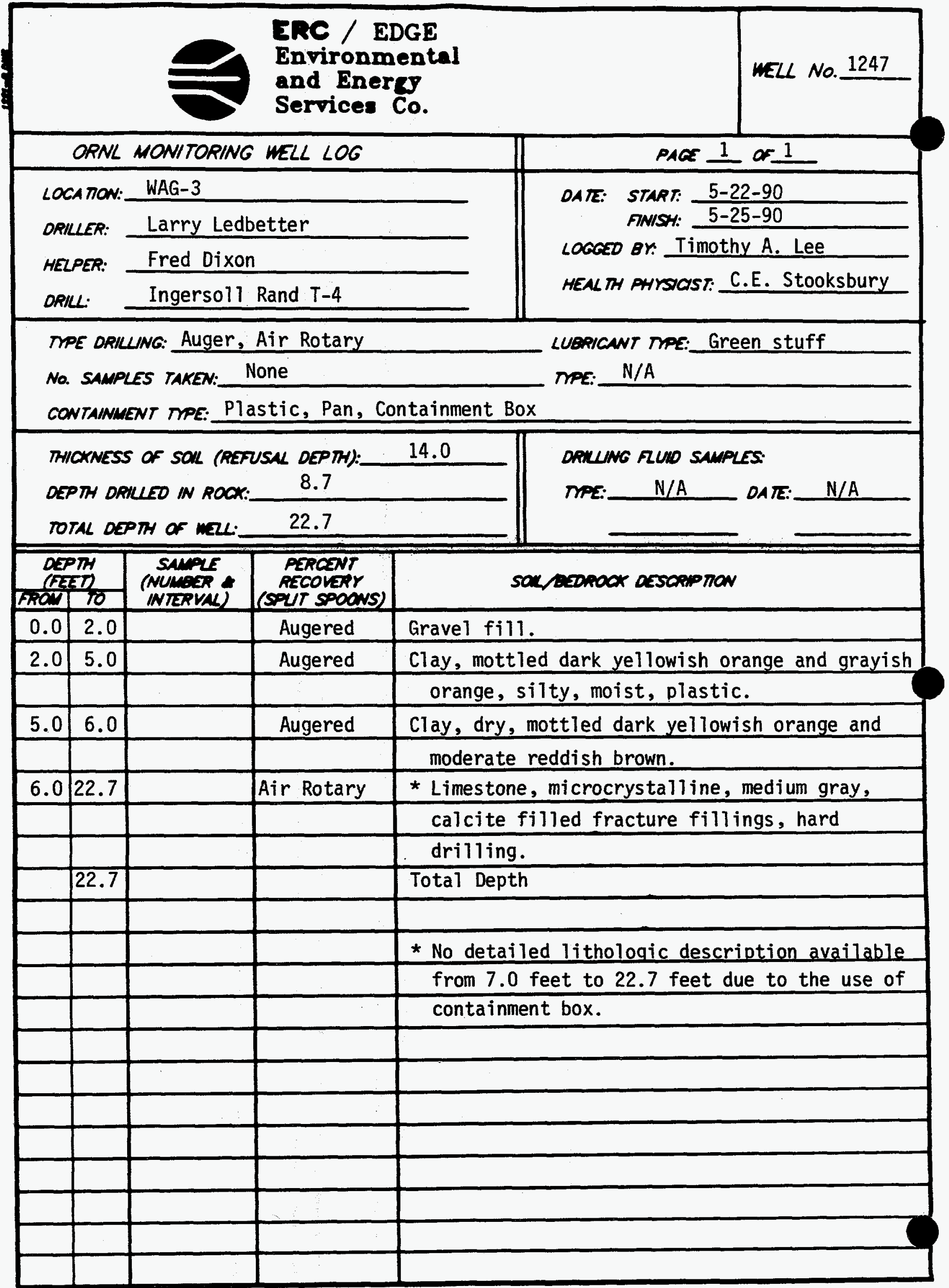




\section{MONITORING WELL MATERIALS CERTIFICA TION}

ITEM/MA TERIAL

SAND

BENTONITE

STAINLESS STEEL SCREEN

STAINLESS STEEL CASING

STAINLESS STEEL CENTRALIZERS

STAINLESS STEEL CAPS

MONITORING MELL PUMP

GROUT

WELL COVERS

SURFACE CASING

\begin{tabular}{|c|c|c|}
\hline & DATE USED & BATCH NUMBER \\
\hline & $5 / 25 / 90$ & 2 \\
\hline Powder & $5 / 25 / 90$ & 1 \\
\hline Pellets & $5 / 25 / 90$ & 7 \\
\hline $\begin{array}{ccc}1 G E D & \text { RES } \\
\text { NO }\end{array}$ & $5 / 25 / 90$ & 5 \\
\hline $\begin{array}{c}\text { YES } \\
\text { AEED } \\
\text { NO }\end{array}$ & $5 / 25 / 90$ & 5 \\
\hline $\left.\begin{array}{ll}\text { IESD } \\
\text { nOS }\end{array}\right)$ & $5 / 25 / 90$ & 5 \\
\hline $1 G E D\left(\begin{array}{ll}\text { YES } \\
\text { NO }\end{array}\right)$ & $5 / 25 / 90$ & 5 \\
\hline 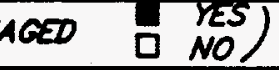 & $8 / 23 / 90$ & 8 \\
\hline & $5 / 25 / 90$ & 9 \\
\hline & $N / A$ & $N / A$ \\
\hline
\end{tabular}

COMMENTS:

(PREPACKACED

(PREPACKAGED

(PREPACKAGED

(PREPACKAGED
(PREPACKAGED
(PREPACKAGED
(PREPACKAGED
(PREPACKAGED

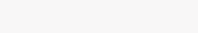




\section{POST-WELL COMPLETION CHECKLIST}

\section{POST-MELL COMPLETON TASKS}

1. MU SCRAPED FRON AUEZRS SHMPLERS ANO AL OTHEP EQUIPISNT.

2. ALL WUO FRON RIG AND EQUPIENT SCPAPWOS ANO

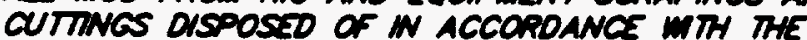
SPECHTCA IION PROWOSD.

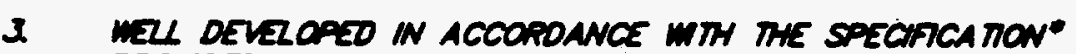
PROVOSD AND OETAKS OF THE OEVELOPUENT ACTVT RECOROED.

4. DRULNG STE PROPERLY CLEAND UP AFTRP

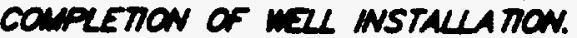

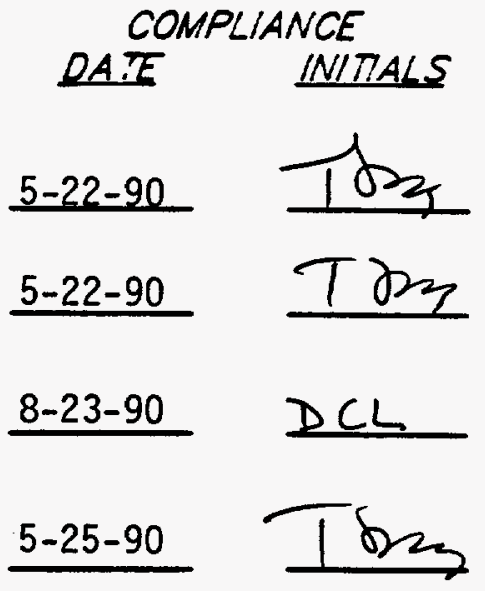

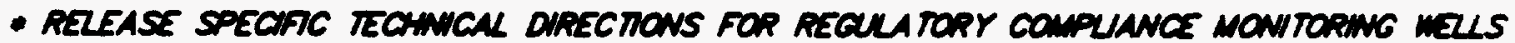
PHASE !. OAK RIDCE NATIONAL LABORA TORY, ONK AIDEE W.O. $\mathrm{K}-4147$, APAK 1967.

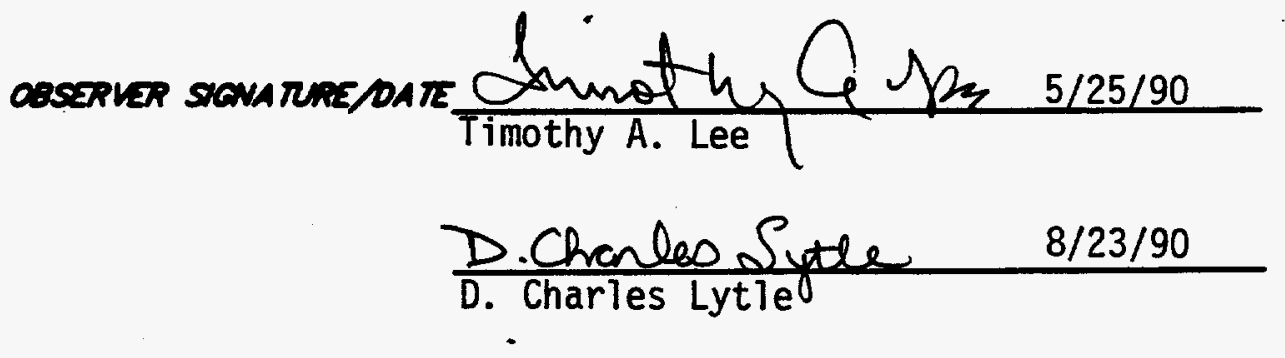




\section{MONITORING WELL \\ DEVELOPMENT FORM}

DEVELOPMENT DETAILS

METHOD OF

DEVELOPMENT: Surging and Pumping

OEVELOPMENT

BEGAN DATE:

$8 / 06 / 90$

TME:

DEVELOPMENT

ENOING DATE:

$8 / 23 / 90$

DEVELOPMENT

OBSERVED BY.

D. Charles Lytle

ONE WELL VOLUME: 7.3 GALLONS

TOTAL GALLONS PUMPED: 8 TOTAL WELL VOLUMES PUMPED: 1.1

NITAL PH:-_-- FNAL PH:_- -

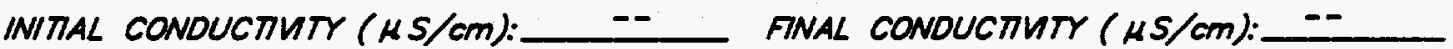

OESCRIPTION OF INITAL TURBIOITY:CCTOUdY

OESCRIPTION OF FNAL TURBIDITY: Cloudy

FNAL MEASURED TURBIDITY Greater than 100 NTU's

WELL APPROVED BY: R. C. Willi ams MMES

\begin{tabular}{|c|c|c|}
\hline $\begin{array}{l}\text { ODOR } \\
\text { Of MATER: }\end{array}$ & Jone & \\
\hline $\begin{array}{l}\text { WATER } \\
\text { DISCHARGED } \\
\text { TO: }\end{array}$ & $\begin{array}{l}\text { D GROUND SURFACE } \\
\text { STORM SEWERS } \\
\text { STRUNS }\end{array}$ & $\begin{array}{l}\text { 口 TANK TRUCK } \\
\text { STORAGE TANKS } \\
\text { OTHER }\end{array}$ \\
\hline
\end{tabular}

INITAL PRE-DEVELOPMENT

WA TER DEPTH:

18.2 feet from ground surface.

\section{DEVELOPMENT OBSERVATIONS}

Very poor producer, pumped dry in a matter of minutes and stayed dry.

Didn't get enough water for a test, we washed well with D.I. water and called it finished on 8-23-90.

OBSERVER SIENATURE DATE D. Chanlod \& eyte 8/23/90 D. Charles Lytle 


\section{HYDRAULIC CONDUCTIVITY CALCULATIONS}

PROGRAM SLUGT, VERSION 4.1, NOV. 1986

THIS PROGRAM CALCULATES MEAN TRANSMISSIVITIES FROM

SLUG-TEST DATA BASED ON TWO ANALYTICAL APPROACHES:

(1) METHOD OF COOPER, BREDEHOEFT AND PAPADOPULOS, 1967

(ARTICLE IN VOL. 3, NO. 1 OF WRR ENTITLED

"RESPONSE OF A FINITE DIAMETER WELL TO AN INSTANTANEOUS CHARGE OF WATER")

(2) METHOD OF BOUWER AND RICE, 1976 (ARTICLE IN

VOL. 12, NO.3 OF WRR ENTITLED

"A SLUG TEST FOR DETERMINING HYDRAULIC CONDUCTIVITY

OF UNCONFINED AQUIFERS WITH COMPLETELY OR PARTIALLY PENETRATING WELIS")

WELL NO.: 1247

DATE OF TEST: $8 / 29 / 90$

PROJECT NO.: E221-002

CLIENT: MMES

SITE LOCATION: WAG-3

EDGE, INC. FIELD INVESTIGATOR: JAMES W. CARUTHERS

INPUT DATA ARE:

INNER CASING DIAMETER $=2.00$ INCHES

INNER SCREEN OR OPEN-HOLE DIAMETER $=2.00$ INCHES

DIAMETER OF DRILLED HOLE $=8.00$ INCHES

LENGTH OF SCREEN OR INTAKE PORTION $=15.00$ FEET

DEPTH FROM STATIC LEVEL TO BOTTOM OF SCREEN $=5.42$ FEET

THICKNESS OF SATURATED AQUIFER ZONE $=15.00$ FEET

DEPTH TO STATIC WATER LEVEL BELOW REF. POINT $=5.51$ FEET

ESTIMATED POROSITY OF GRAVEL PACK $=.20$

FALLING-HEAD INDEX = 0 ("1" IF FALIING, "0" IF RISING)

NUMBER OF DEPTH-TIME DATA POINTS = 32

HO WAS COMPUTED FROM INTERCEPT OF PLOT OF LOG(H) VS. TIME

SUCCESSIVE COMPUTED

VALUES FOR HO

(FEET)

$$
.7740
$$

.7814

PAGE 13 of 16 


\begin{tabular}{|c|c|c|}
\hline$\left(\operatorname{SEC}^{\text {TIME }}\right)$ & $\begin{array}{l}\text { DEPTH TO WATER } \\
\text { (FEET) }\end{array}$ & $\begin{array}{l}\text { HEAD } \\
\text { (FEET) }\end{array}$ \\
\hline $\begin{array}{r}10.00 \\
20.00 \\
30.00 \\
40.00 \\
50.00 \\
60.00 \\
75.00 \\
90.00 \\
105.00 \\
120.00 \\
150.00 \\
180.00 \\
240.00 \\
300.00 \\
360.00 \\
420.00 \\
480.00 \\
540.00 \\
600.00 \\
720.00 \\
840.00 \\
960.00 \\
1080.00 \\
1200.00 \\
1320.00 \\
1440.00 \\
1560.00 \\
1680.00 \\
1800.00 \\
1920.00 \\
2040.00 \\
2160.00\end{array}$ & $\begin{array}{l}3.850 \\
4.150 \\
4.370 \\
4.540 \\
4.640 \\
4.710 \\
4.760 \\
4.810 \\
4.840 \\
4.850 \\
4.880 \\
4.900 \\
4.930 \\
4.950 \\
4.960 \\
4.970 \\
4.980 \\
4.990 \\
5.000 \\
5.000 \\
5.010 \\
5.020 \\
5.030 \\
5.030 \\
5.030 \\
5.040 \\
5.040 \\
5.050 \\
5.050 \\
5.050 \\
5.060 \\
5.050\end{array}$ & $\begin{array}{r}1.660 \\
1.360 \\
1.140 \\
.970 \\
.870 \\
.800 \\
.750 \\
.700 \\
.670 \\
.660 \\
.630 \\
.610 \\
.580 \\
.560 \\
.550 \\
.540 \\
.530 \\
.520 \\
.510 \\
.510 \\
.500 \\
.490 \\
.480 \\
.480 \\
.480 \\
.470 \\
.470 \\
.460 \\
.460 \\
.460 \\
.450 \\
.460\end{array}$ \\
\hline
\end{tabular}




\title{
HYDRAULIC CONDUCTIVTY CALCULATIONS
}

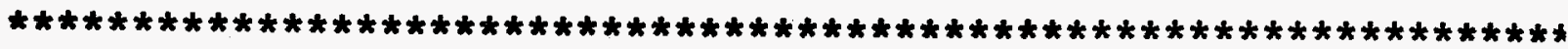 \\ METHOD OF BOUWER AND RICE \\ COMPUTED RESULTS USING DIAMETER OF DRILLED HOLE:

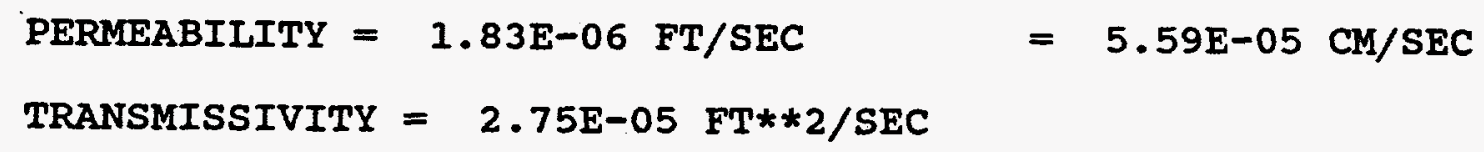


EROE

Environmental

and Energy

WELL NO. 1247

Services Co.

\section{HYORAULIC CONDUCTIVTY CALCULATIONS}

10.0

8.0.

7.0

6.0.

I.0

4.0

3.0

2.0

11

1.5

12

.

w 0.9

L $\quad 0.8$

$\geqq \quad 07$

$\underset{1}{\longrightarrow} \quad 0.6$

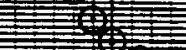

또

0.3

5

3

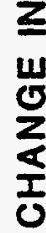

0.2

1

$\square$

0.15

W

$\frac{2}{3}$

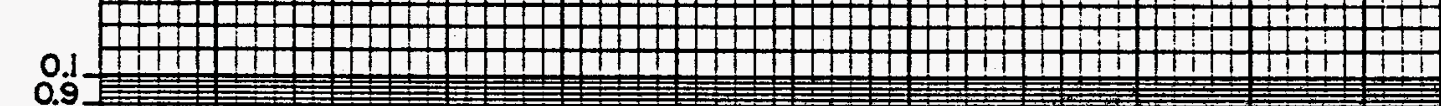

0.08

0.07

0.06

0.05

0.04

0.03

0.02

12
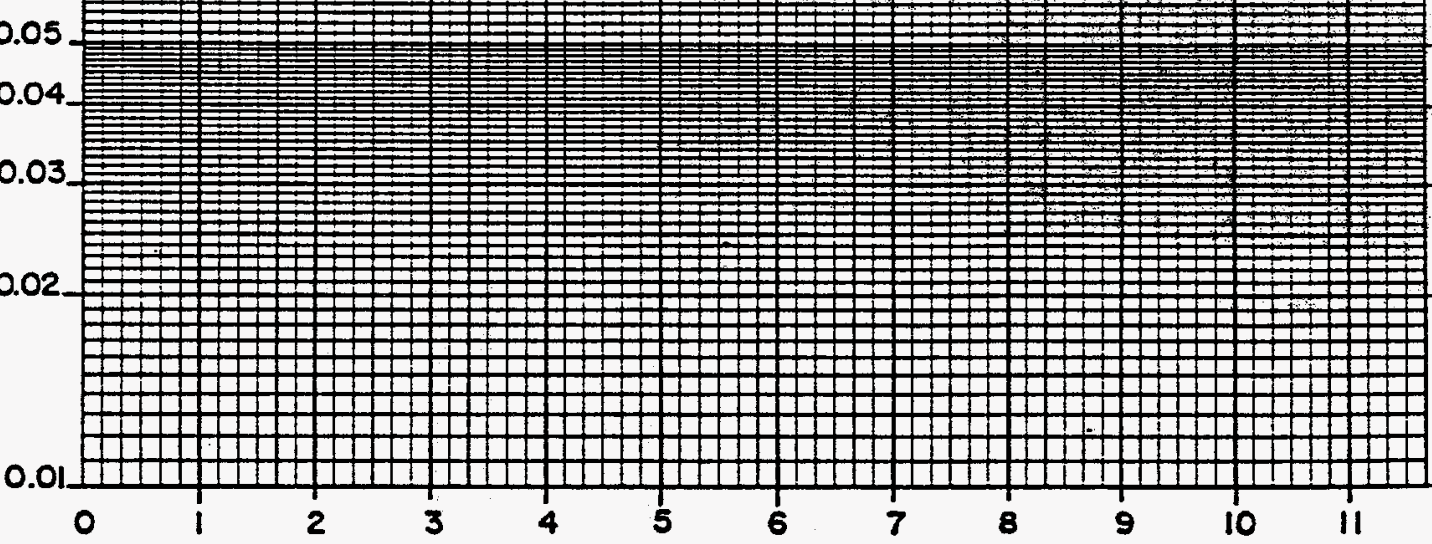

TIME IN MINUTES 


\subsection{General Information}

\subsection{Nell Location}

Monitoring well number 1248 is located in WAG 3. It is located on the western boundary of WAG 3 near Highway 95. The location is shown on ORNL drawing number C3E20004 A075. Survey coordinates for this well are $N 21,366.9229, \mathrm{E} 24,654.0797$ (X-10 grid) or latitude $35^{\circ}-54^{\prime}-55.26^{\prime \prime}$ and longitude $84^{\circ}-20^{\prime}-00.91^{\prime \prime}$. Coordinate data were provided by Martin Marietta Energy systems. The method used for conversion from $\mathrm{X}-10$ grid to Tennessee-Lambert state Plane Coordinates came from the publication "Tennessee Valley Authority Data Services Branch and Mapping Services Branch, Oak Ridge, Tennessee, DOE Plant Control, November 6, 1985, Field Book: ESS-3115, pp. 1-20." The latitude and longitude were calculated by Adams Craft Herz Walker Engineering, Inc., using methods from the U.S. Coast and Geodetic Survey Publication 62-4, "State Plane Coordinates by Automatic Data Processing."

\subsection{Drilling Information}

Well number 1248 was drilled by Geotek Engineering Company. An Ingersoll-Rand $\mathrm{T}-4 \mathrm{rig}$ was used to drill this boring for monitor well installation under operation of Larry Ledbetter with the assistance of Fred Dixon. Drilling commenced on 5-15-90 and was finished on 5-29-90. Paragraph 2.4.1 includes a detailed discussion of the well installation and a well schematic is included on the well installation/ completion form. A synopsis of the drilling activity 
follows. This information was typed directly from field notes and was edited only when necessary for clarification.

5-15-90 The rig was moved to location and set up on plastic. Split spoon samples were taken from surface to 13.0 feet.

5-17-90 Split spoon samples were taken from 13.0 feet to refusal at 14.0 feet. Reamed hole to 8.3 feet using a 22-inch auger and set 8.3 feet of deconta-minated steel diverter casing with 12 sacks of cement.

5-18-90 Drill from 8.3 feet to 20.0 feet using a 14-inch air rotary tricone bit into containment box. set 20.0 feet decontaminated steel surface casing with 7.0 sacks grout.

5-21-90 Drill from 20.0 feet to 52.5 feet using an 8-inch air rotary tricone bit into containment box.

5-22-90 Drill from 52.5 to 72.5 feet. Not much water.

5-29-90 Decide to set well casing without much water in hole. Set 4-inch stainless steel casing and screen with sandpack and bentonite seal.

5-30-90 Grout annulus with 8 sacks cement.

This well was logged by ERC Environmental and Energy Services Co., Inc., hydrogeologist Timothy A. Lee. 
All well construction materials and supplies were from Martin Marietta Energy Systems approved batches. The batch origin of individual items is shown on the included Monitoring Well Materials Certification form.

\subsection{Technical Information}

\subsection{Decontamination Procedures}

The drilling rig, down hole tools, surface casing, stainless steel screen, stainless steel casing, centralizers, and stainless steel silt trap underwent the cleaning decontamination procedures outlined in the drilling specifications (Release specific Technical Directions for Regulatory Compliance Monitoring Wells Phase 1, Oak Ridge National Laboratory, Oak Ridge, w.O. K-4147, April 1987, pgs. 2-4). A checklist of the cleaned materials is included with this data package.

\subsection{Geology}

WAG 3 is located in Melton Valley which is in the Valley and Ridge Physiographic Province of East Tennessee. WAG 3 is underlain by limestone, siltstone and shale of the Middle Ordovician Chickamauga Group. The Chickamauga Group consists of eight units, designated by letters "A" to "H" (Stockdale, 1951). WAG 3 is underlain by units E, F, $G$ and $H$. These units consist of thin bedded nodular limestone with clay and shale partings. A portion of unit $H$ and unit F consists of calcareous siltstone alternating with 
beds of olive gray to maroon shale. Strike and dip varies from $N 45^{\circ} \mathrm{E}$ to $\mathrm{N} 55^{\circ} \mathrm{E}$ and $25^{\circ}$ to $35^{\circ}$ southeast, respectively.

\section{3 sample collection}

No samples were collected for chemical analysis.

A bulk density soil sample was collected from the split spoon sample interval from $5.4 '$ to 5.7'. The sample was measured and weighed, and a bulk density of $2.28 \mathrm{grams} / \mathrm{cm}^{3}$ was calculated.

The Ingersoll-Rand T-4 compressed air was sampled with a cloth filter inserted between drill rods on 5-21-90. The sample was examined with an ultraviolet light for the pressure of hydrocarbons. The filter showed no detectable signs of hydrocarbons.

\subsection{Installation and Development}

\subsubsection{Installation}

This was a "Type B" well. A 22.0-inch diameter boring was augered from ground surface to 8.3 feet. A 15 1/4-inch diverter casing was installed from surface to 8.3 feet below ground surface and grouted in place. The boring was then extended past the diverter casing depth with a 14.0-inch air rotary tricone roller bit from 8.3 feet to 20.0 feet. A 10.0 - inch diameter string of decontaminated steel surface casing was installed from 0.0 feet to 20.0 feet, sealed with a 1.5- foot bentonite pellet layer from 18.5 feet to 
20.0 feet, and tremie grouted in place. The surface casing minimizes potential cross contamination between the regolith and bedrock water bearing zones. After the surface casing was installed, the air rotary method was used to drill an 8-inch diameter boring to a total depth of 72.5 feet. A 4-inch diameter stainless steel screen with threaded bottom cap was installed from 52.3 feet to 72.5 feet. A 4-inch diameter stainless steel casing was installed from the top of the screen at 52.3 feet and extended 2.21 feet above ground surface. A sandpack was then tremied into the annular space from 47.9 to 72.5 feet, with a 3.7-foot bentonite pellet seal poured into the annular space above the sandpack from 44.2 to 47.9 feet. The annular space from the top of the bentonite seal to the surface was tremie grouted with a cement/bentonite slurry. A detailed schematic of the well is included on the well installation/completion form.

\section{4 .2 We11 Development}

Well number 1248 did not produce sufficient water to develop. Well made less than 1 gallon/day. Well was washed with deionized water and the monitoring well pump installed.

\subsubsection{Installation of Dedicated Monitoring Well Pump}

After the well was developed, a Geoguard Model No. 5614 dedicated monitoring well pump was installed on 8-23-90 at a depth of 68.0 feet below ground surface. These pumps are decontaminated at American Sigma and 
are sent prepackaged.

A copy of the pump certification is kept on file at ORNL.

\subsection{Hydraulic conductivity Testing}

Well number 1248 was tested for the determination of hydraulic conductivity of the aquifer in the vicinity of the well screen. This was accomplished by instantaneously adding a known quantity of water to the monitoring well and measuring the recovery of the water level over time. The changing water levels were measured using a Druck 15 psig pressure transducer and an Omnidata Datapod II data recorder. The hydraulic conductivity value of $7.55 \times 10^{-7} \mathrm{~cm} / \mathrm{second}$ (shown as permeability on the hydraulic conductivity calculations printout attached) was calculated using the Bouwer and Rice method. A computer printout of the hydraulic conductivity calculations is included in this data package. 


\section{PRE-DRILLING CHECKLIST FOR MONITORING WELLS}

\section{RRE-DRILUNG TASKS}

1. EXCAVTION PERMIT OBTAINED

2. ALL EOUIPMENT HAS BEEN CLEANED BEFORE DRILLING.

30. SCREEN AND CASING HAVE BEEN WASHED, STEAMED, RINSED WTH DE-IONIZED OR DISTILED WATER, RINSED WTH ISOPROPR ALCOHOL, WRAPPED WTH PROTECTVE COVERING AND STORED OFF THE GROUND.

36. PRE-PACKAGED SCREENS, CASNG AND CENTRALIZERS WERE USED.

4. WORK AREA FOR SAMPLE EXAMINATION COVERED WIH CLEAN POL VETHRENE.

5. CLEAN KNIVES, GLOVES, SAMPLE JARS AND LABELS ON HAND.

6. POL YETHYENE COVER IN PLACE OVER HOLE.

7. AIR ROTARY COMPRESSED AIR SAMPLED. COMPLANCE

\begin{tabular}{|c|c|}
\hline \multicolumn{2}{|c|}{ COMPLIANCE } \\
\hline$\frac{\text { DAIE }}{5-15-90}$ & INIJALS \\
\hline $5-15-90$ & 82 \\
\hline$N / A$ & \\
\hline
\end{tabular}
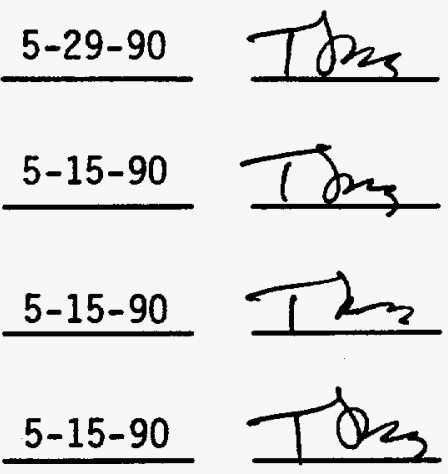

$5-21-90$

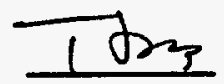

RESULTS. Sample showed no detectable signs of hydrocarbons under an ultraviolet light.

ADOITIONAL NOTES/OBSERVATIONS: 


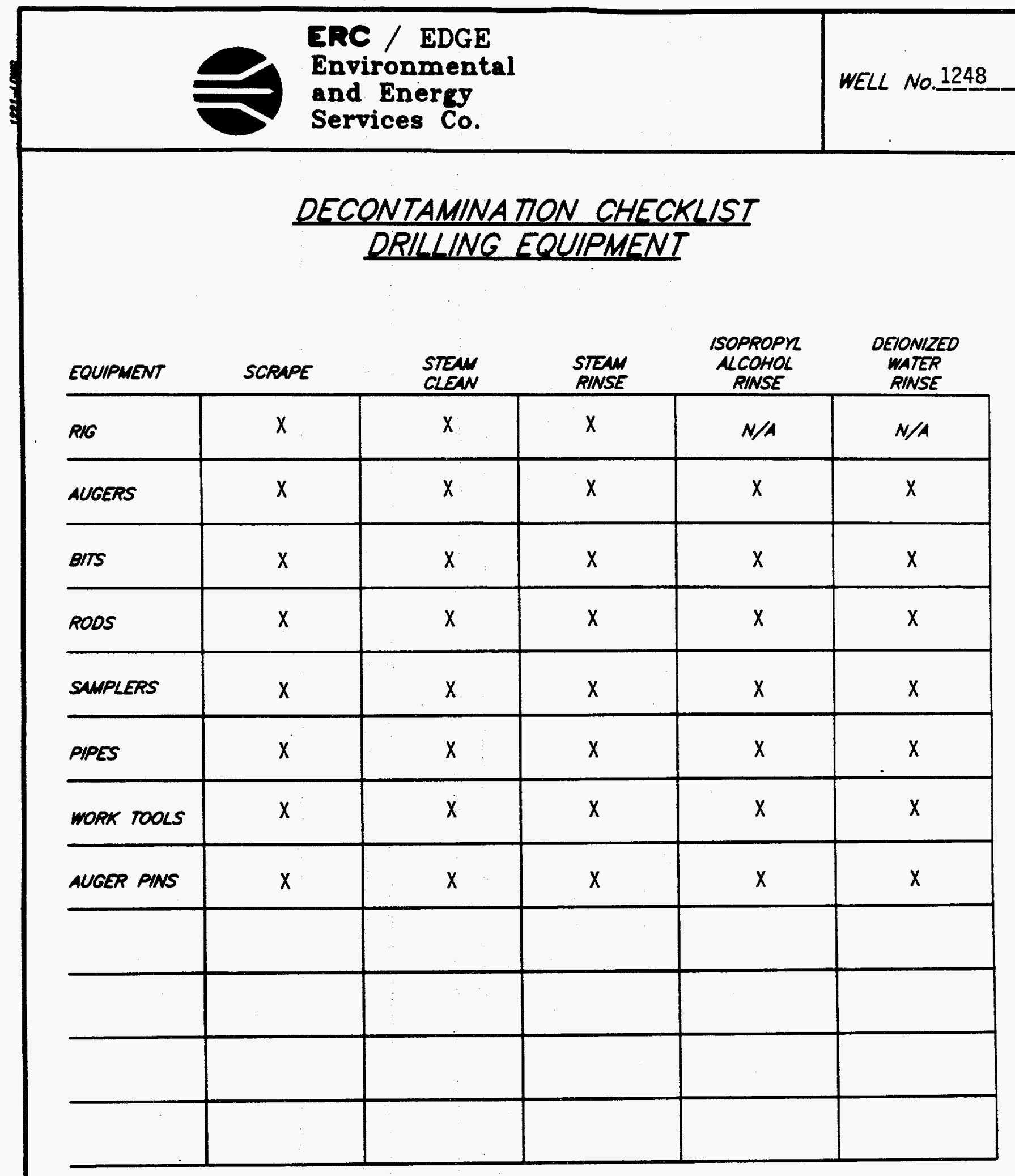

OBSERVER SIGNATURE/OATE $\frac{\text { Shmoth }}{\text { Timothy A. Lee }}$ 


\section{ORNL MONITORING WELL LOG}

LOCAnON: WAG-3

ORILLE: Larry Ledbetter

HELPER: Fred Dixon

ORILL: Ingersoll Rand T-4
PACE 1 or 2

OAT: START: $\frac{5-15-90}{5-29-90}$

FNISH: $5-29-90$

LOGGED Br. Timothy A. Lee

HEAL TH PHISICAST: C.E. Stooksbury

TPE ORIUNG: Split Spoon, Auger, Air Rotary LUBRICANT MPE: Green stuff

No. SIMPLES TAKEN: None MPE: N/A

CONTanment mpe: Plastic, Pan, Containment Box

THIOKNESS OF SOL (RETUSA DEPIH): 14.0

OEPTH ORILLO IN ROOK:

TOTAL OEPH of MEL.
58.5

72.5
DRUUNG FUND SAMPLES:

MPE: N/A DAR: N/A

\begin{tabular}{|c|c|c|c|c|}
\hline \multicolumn{2}{|c|}{ OEPIH } & $\begin{array}{l}\text { SAMPLE } \\
\text { (NUMGER A } \\
\text { NTIERVAL) }\end{array}$ & $\begin{array}{c}\text { PERCENT } \\
\text { RECOVERY } \\
\text { (SPUT SPOONS) }\end{array}$ & san peconocor arscription \\
\hline 0.0 & 1.0 & & Augered & Gravel fill. \\
\hline 1.0 & 2.0 & & $25 \%$ & Gravel fill. \\
\hline \multirow[t]{2}{*}{2.0} & 3.0 & & $25 \%$ & Clay, mottled dark yellowish orange and grayish \\
\hline & & & & orange, silty, moist, plastic. \\
\hline \multirow[t]{3}{*}{3.0} & 5.0 & & $25 \%$ & Clay, dark yellowish orange, dry; gravel sized \\
\hline & & & & limestone, medium crystalline, olive gray, \\
\hline & & & & dry. \\
\hline \multirow[t]{4}{*}{5.0} & 7.0 & & $60 \%$ & Clay, dry, moderate reddish brown, black \\
\hline & & & & streaks; scattered limestone, medium \\
\hline & & & & crystalline. Bulk density taken from $5.4^{\prime}$ to \\
\hline & & & & $5.7^{1}$ is $2.28 \mathrm{~g} / \mathrm{cm}^{3}$ \\
\hline \multirow[t]{3}{*}{7.0} & 9.0 & & $75 \%$ & Clay, dry, mottled dark yellowish orange and \\
\hline & & & & moderate reddish brown, black streaks. \\
\hline & & & & Cavity at 8.8 to 9.0 feet was dry and dusty. \\
\hline \multirow[t]{2}{*}{9.0} & 11.0 & & $100 \%$ & Clay, dry, mottled dark yellowish orange and \\
\hline & & & & moderate reddish brown, silty. \\
\hline \multirow[t]{2}{*}{11.0} & 12.0 & & $50 \%$ & Clay, dry, silt, mottled dark yellowish orange \\
\hline & & & & and moderate reddish brown. \\
\hline \multirow[t]{3}{*}{12.0} & 13.0 & & $50 \%$ & Mostly clay, mottled dark yellowish orange and \\
\hline & & & & moderate reddish brown, very dry and dusty, \\
\hline & & & & scattered limestone fragments, medium \\
\hline
\end{tabular}




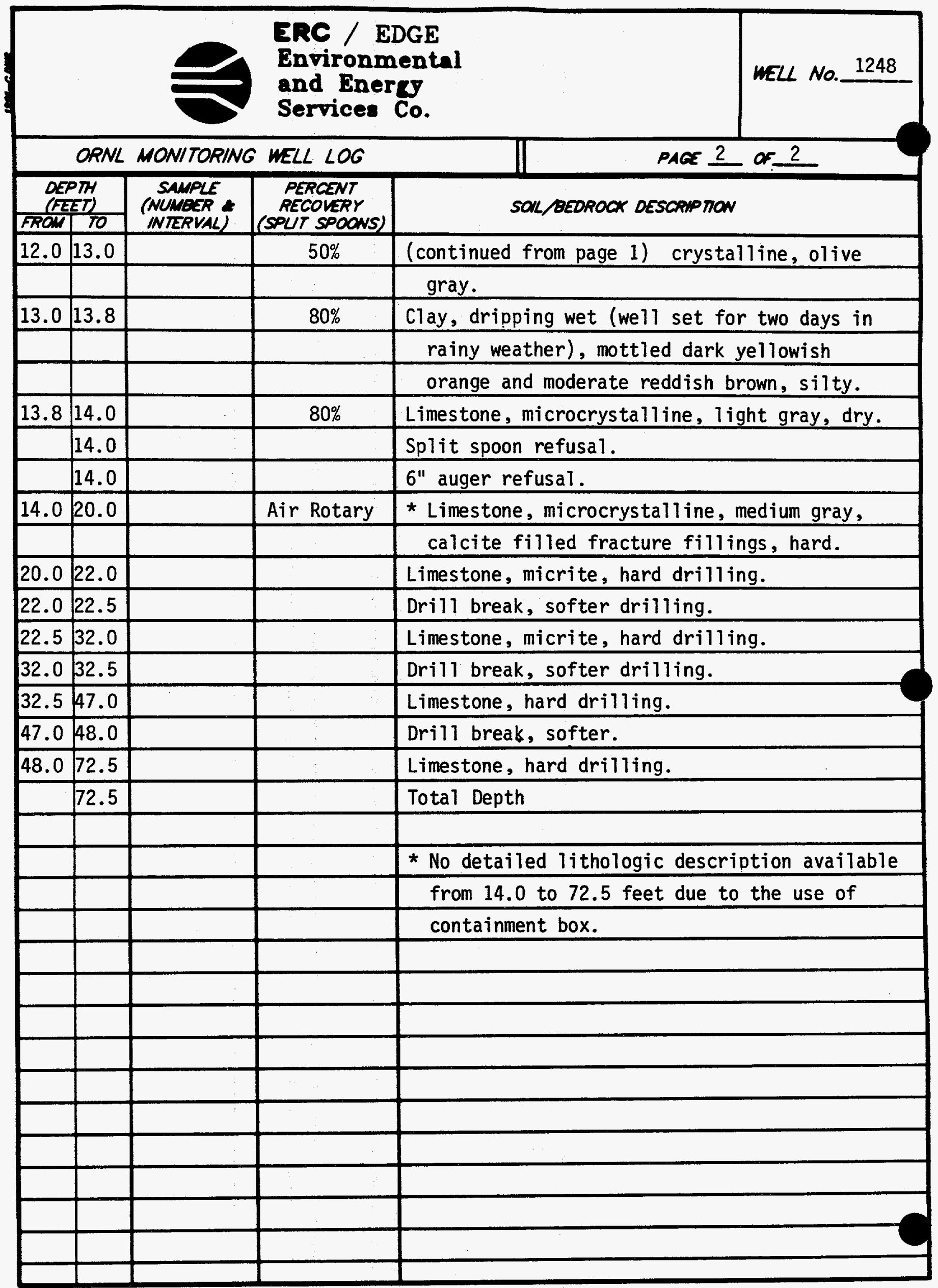




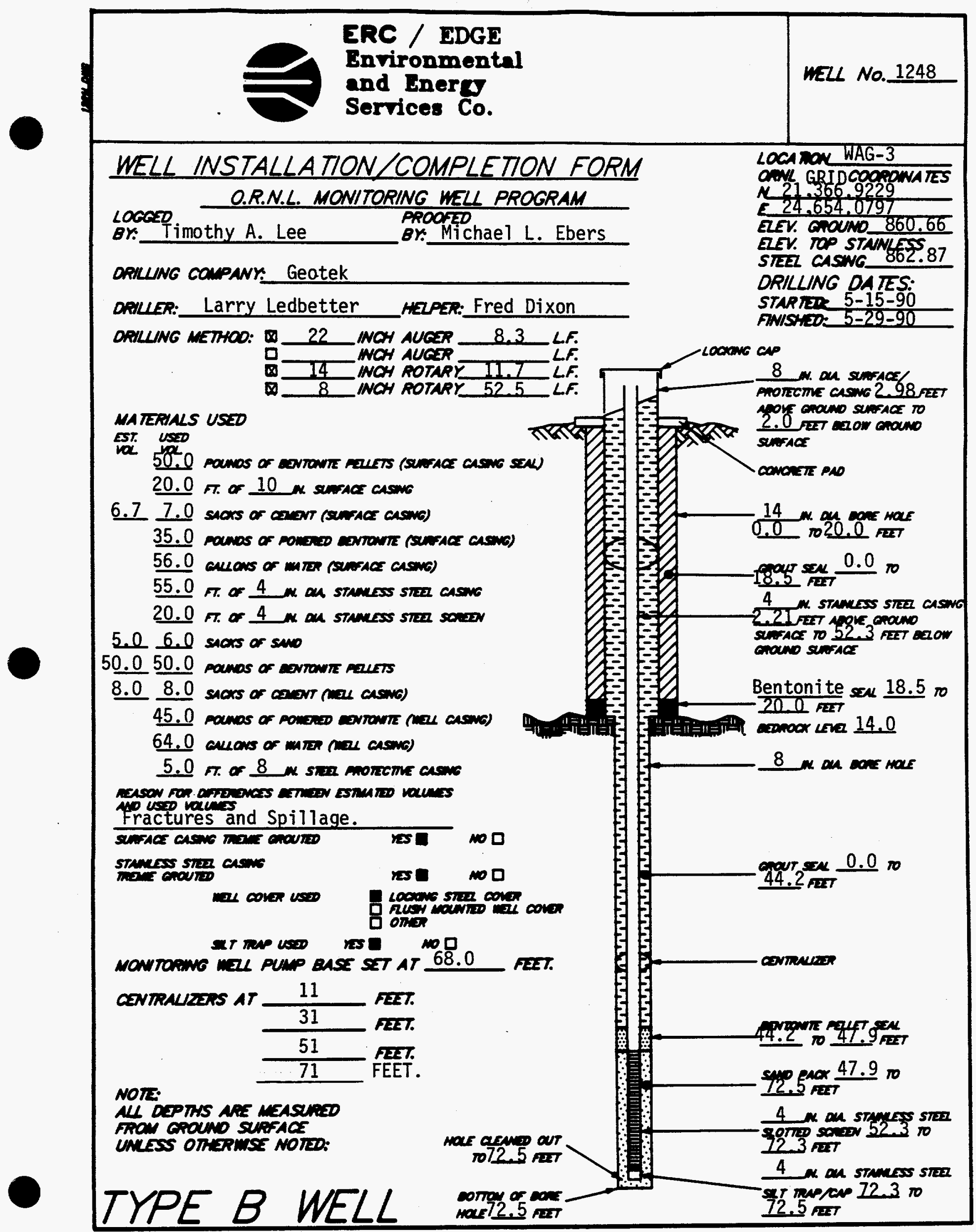

pace 11 or 18 
ERe / EDGE

Environmental

WELL NO.1248

and Energy

Services Co.

OATE: $5 / 29 / 90$

\section{MONITORING WELL MA TERIALS CERTIFICATION}

ITEM/MA TERIAL DATE USED BATCH NUMBER

SAND

BENTONITE

Powder
Pellets

STAINLESS STEEL SCREEN

STAINLESS STEEL CASING

STAINLESS STEEL CENTRALIZERS

STAINLESS STEEL CAPS

MONITORING WELL PUMP

GROUT

Surface

Well Casing

WELL COVERS

SURFACE CASNEG

(PREPACKAGED

(PREPACKAGED

(PREPACKAGED

(PREPACKAGED

(PREPACKAGED

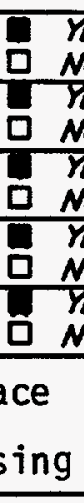

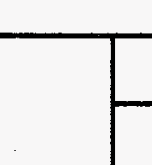

\begin{tabular}{l|l}
\hline & \\
\hline
\end{tabular}

\begin{tabular}{|l|l|l}
\hline & $5-30-90$ & 1 \\
\cline { 2 - 3 } & $5-29-90$ & 7 \\
\hline NES & $5-29-90$ & 5
\end{tabular}


ERC / EDGE

Environmental

and Enerey

WELL No. 1248

Services Co.

\section{POST-MELL COMPLETION CHECKLIST}

\section{ROST-WELL COMPLETON TASKS}

1. MUD SCRAPED FRON AUGERS SAMPLERS ANO ALL OTHER EQUIPNENT.

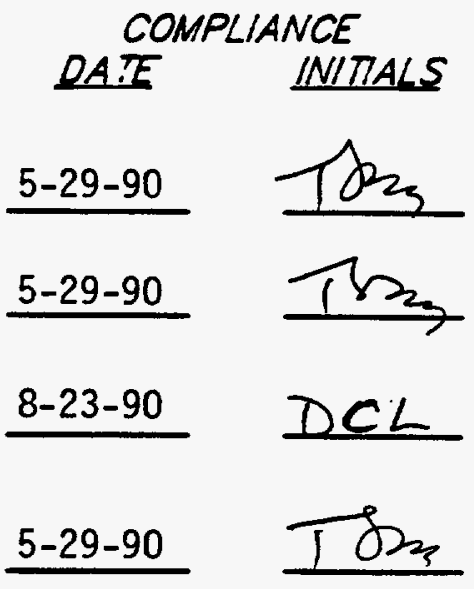

4. DRULNG STE PROPERLY CLEANED UP AFTER

COMPLETION OF MIL INSTALLATON.

2. ALL WUD FROM RIG ANO EQUPWENT SCRAPINCS INO CUTTINOS DASPOSED OF W ACCORDANCE WIH THE SPECAFCA IION" PROVDED.

3. WEU OEVELOED IN ACCOROANCE WIH THE SPECAFCA NON. PROVOED ANO OETALS OF THE OEVZLOPWENT ACTUTH RECOROED.

- REZEASE SPECHFC TECAMUCAL OARECTONS FOR REQULATOPY COMPUANCE MONITORMG WZLS PHASE 1. OAK RIDCE NAMONAL LABOPATOPY, ONK RDOE, W. K-4147, APRI 1987.

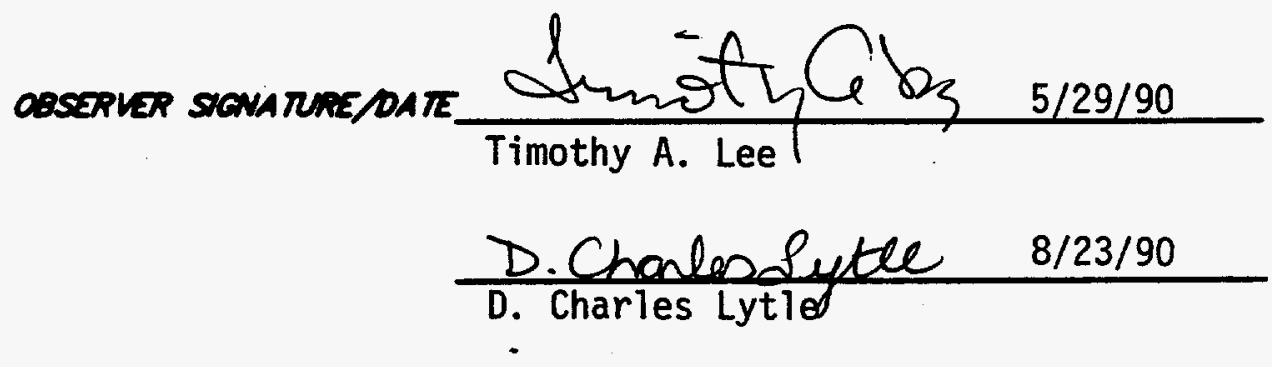




\section{MONITORING WELL \\ DEVELOPMENT FORM}

DEVELOPMENT DETAILS

METHOD OF

OEVELOPMENT: Surging and Pumping

DEVELOPMENT:
BEGAN OATE:

TME:

OEVELOPMENT

ENDING DATE: $\quad 8-23-90$

DEVELOPMENT

OBSERVED BY:

D. Charles Lytle

ONE MELL VOLUNE: 44.0 GALLONS

TOTAL GALLONS PUMPED:_ 1 TOTAL MELL VOLUMES PUMPED:__--

INITAL PH: - -

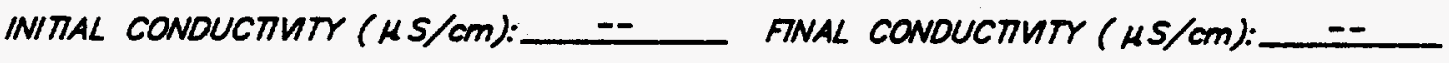

OESCRIPTION OF INITAL TURBIDITY: ClOUdY

DESCRIPTION OF FINAL TURBIDITY:_CTOUdY

FINAL MEASURED TURBIDIT:___ Greater than 100 NTU's

\begin{tabular}{|c|c|c|c|}
\hline $\begin{array}{l}\text { OOOR } \\
\text { OF MATIER: }\end{array}$ & None & & \\
\hline $\begin{array}{l}\text { WA TER } \\
\text { OISCHARGED } \\
\text { TO: }\end{array}$ & & $\begin{array}{l}\triangle \text { GROUND SURFACE } \\
\square \text { STORM SEMERS } \\
\square \text { DRUMS }\end{array}$ & $\begin{array}{l}\text { 口 TANK RRUCK } \\
\text { STORAGE TANKS } \\
\text { D OTHER } \\
\end{array}$ \\
\hline
\end{tabular}

INITAL PRE-DEVELOPMENT

WATER DEPTH:

34.2 feet from ground surface.

\section{DEVELOPMENT OBSERVATIONS}

Very poor producer, pumped dry in less than a minute and stayed dry with no sign of recharge. Didn't get enough water for sample. Washed with

D. I. water and called it finished on 8-23-90.

OBSERVER SIGNATURE/DATE D. Chonleosiyte $8 / 23 / 90$

D. Charles Lytle 


\title{
HYDRAULIC CONDUCTIVTY CALCULATIONS
}

PROGRAM SLUGT, VERSION 4.1, NOV. 1986

THIS PROGRAM CALCULATES MEAN TRANSMISSIVITIES FROM

SLUG-TEST DATA BASED ON TWO ANALYTICAL APPROACHES:

(1) METHOD OF COOPER, BREDEHOEFT AND PAPADOPULOS, 1967

(ARTICLE IN VOI.3, NO. 1 OF WRR ENTITLED

"RESPONSE OF A FINITE DIAMETER WELL TO AN INSTANTANEOUS CHARGE OF WATER")

(2) METHOD OF BOUWER AND RICE, 1976 (ARTICLE IN VOL. 12, NO.3 OF WRR ENTITLED

"A SLUG TEST FOR DETERMINING HYDRAULIC CONDUCTIVITY OF UNCONFINED AQUIFERS WITH COMPLETELY OR PARTIALLY PENETRATING WELLS")

WELL NO.: 1248

PROJECT NO.: E221-002

SITE LOCATION: WAG-3

EDGE, INC. FIELD INVESTIGATOR: JAMES W. CARUTHERS
DATE OF TEST: $8 / 28 / 90$

CLIENT: MMES

\section{INPUT DATA ARE:}

INNER CASING DIAMETER $=4.00$ INCHES

INNER SCREEN OR OPEN-HOLE DIAMETER $=4.00$ INCHES

DIAMETER OF DRILIED HOLE $=8.00$ INCHES

LENGTH OF SCREEN OR INTAKE PORTION $=20.00$ FEET

DEPTH FROM STATIC IEVEI TO BOTTOM OF SCREEN $=41.25$ FEET

THICKNESS OF SATURATED AQUIFER ZONE $=20.00$ FEET

DEPTH TO STATIC WATER IEVEL BELOW REF. POINT $=1.00$ FEET

ESTIMATED POROSITY OF GRAVEL PACK $=.20$

FALIING-HEAD INDEX = 1 ("I" IF FALLING, "O" IF RISING)

NUMBER OF DEPTH-TIME DATA POINTS = 32

HO WAS COMPUTED FROM INTERCEPT OF PLOT OF LOG(H) VS. TIME

\author{
SUCCESSIVE COMPUTED \\ VALUES FOR HO \\ (FEET)
}

3.0091

3.0086 


\section{HYORAULIC CONDUCTIVTY CALCULATIONS}

\begin{tabular}{|c|c|c|}
\hline$\left(\right.$ SEC $\left.^{\text {TIME }}\right)$ & $\begin{array}{l}\text { DEPTH TO WATER } \\
\text { (FEET) }\end{array}$ & $\begin{array}{r}\text { HEAD } \\
\text { (FEET) }\end{array}$ \\
\hline $\begin{array}{l}10.00 \\
20.00 \\
30.00 \\
40.00 \\
50.00 \\
60.00 \\
75.00 \\
90.00 \\
105.00 \\
120.00 \\
150.00 \\
180.00 \\
240.00 \\
300.00 \\
360.00 \\
420.00\end{array}$ & $\begin{array}{l}4.010 \\
4.010 \\
4.010 \\
4.010 \\
4.010 \\
4.010 \\
4.010 \\
4.010 \\
4.010 \\
4.010 \\
4.010 \\
4.010 \\
4.000 \\
4.000 \\
3.980 \\
3.980\end{array}$ & $\begin{array}{l}3.010 \\
3.010 \\
3.010 \\
3.010 \\
3.010 \\
3.010 \\
3.010 \\
3.010 \\
3.010 \\
3.010 \\
3.010 \\
3.010 \\
3.000 \\
3.000 \\
2.980 \\
2.980\end{array}$ \\
\hline $\begin{array}{r}480.00 \\
540.00 \\
600.00 \\
720.00 \\
840.00 \\
960.00 \\
1080.00 \\
1200.00 \\
1320.00 \\
1440.00 \\
1560.00 \\
1680.00 \\
1800.00 \\
1920.00 \\
2040.00 \\
2160.00\end{array}$ & $\begin{array}{l}3.980 \\
3.990 \\
3.980 \\
3.970 \\
3.990 \\
3.980 \\
3.980 \\
3.980 \\
3.980 \\
3.980 \\
3.970 \\
3.960 \\
3.950 \\
3.950 \\
3.940 \\
3.930\end{array}$ & $\begin{array}{l}2.980 \\
2.990 \\
2.980 \\
2.970 \\
2.990 \\
2.980 \\
2.980 \\
2.980 \\
2.980 \\
2.980 \\
2.970 \\
2.960 \\
2.950 \\
2.950 \\
2.940 \\
2.930\end{array}$ \\
\hline
\end{tabular}




\section{HYDRAULIC CONDUCTIVTY CALCULATIONS}

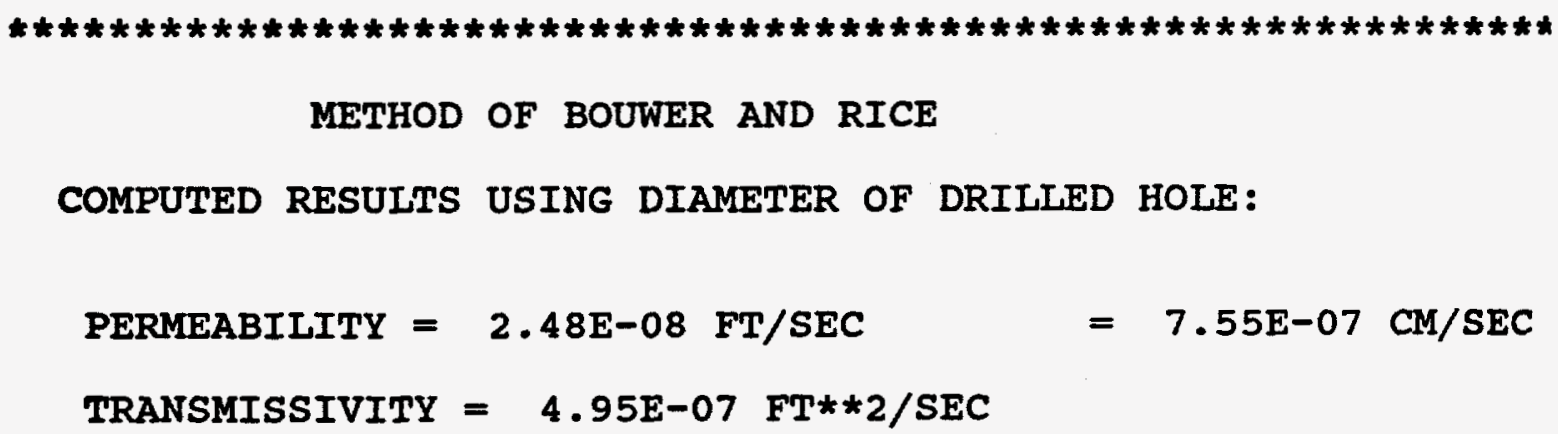




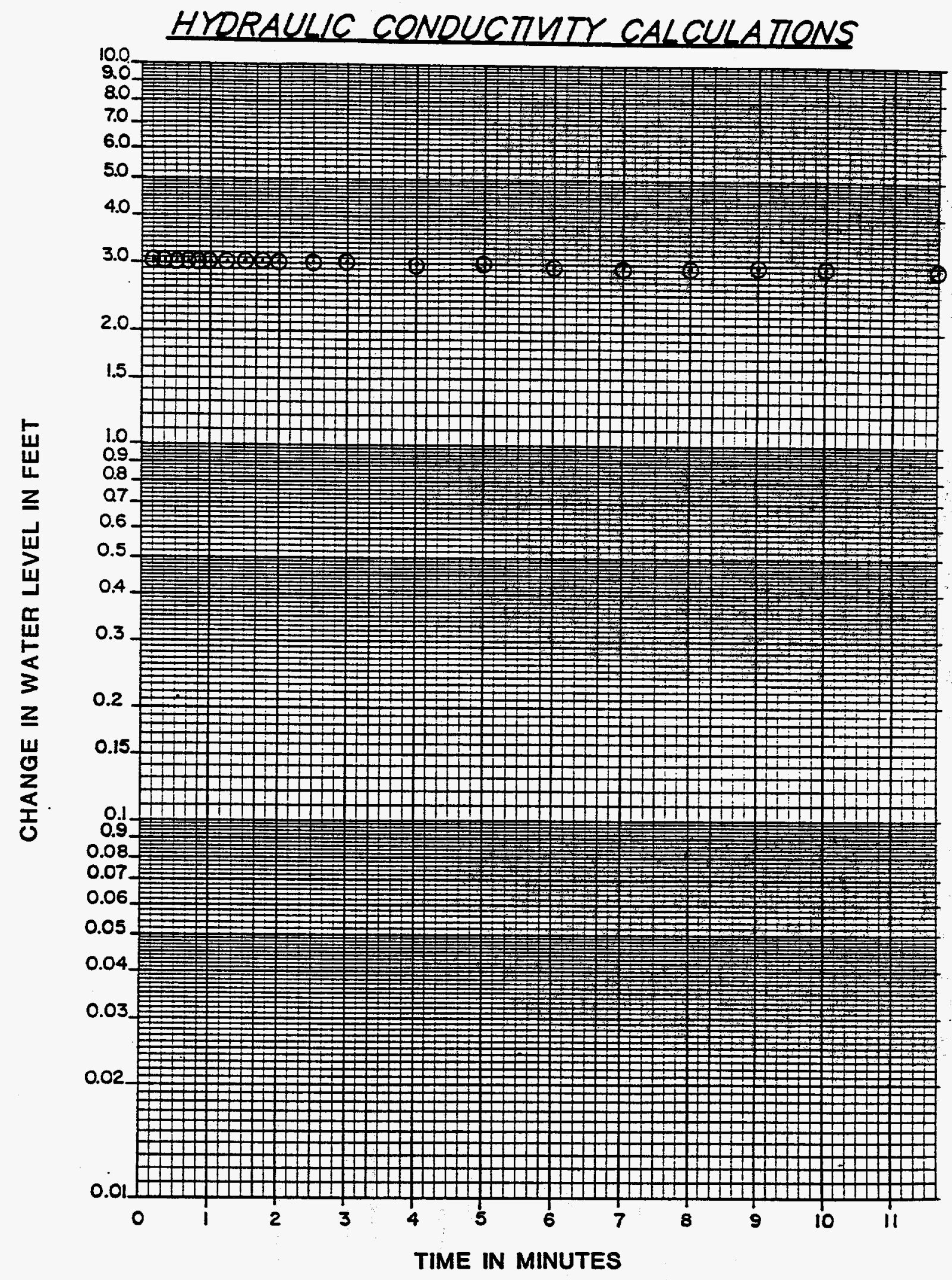


Appendix B

Operating Instructions for Handling Water and Cuttings from Well Drilling and Development of Groundwater Quality Monitoring Wells 


\section{OPERATING INSTROCTIOAS FOR HANDLING COTTINGS AND MATER FROM FROM WELL DRILIING AND DEVELOPLENT OP THE GROUNDWATER QOALITY YONITORING WELLS}

Prepared by

J. A. Greene 


\section{PROCEDURE REVIEW AND APPROVAL Form}

\section{Environmental and Health Protection Division}

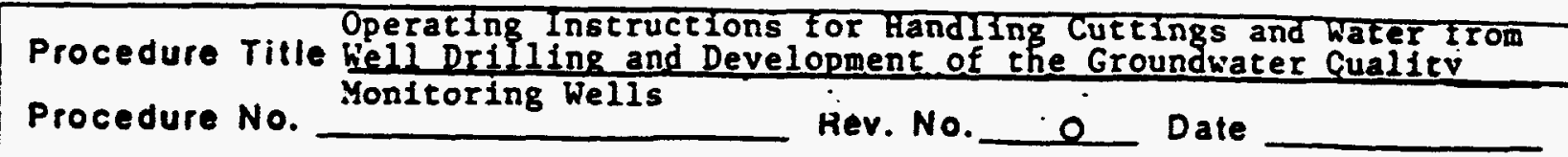

Author

REVIEW AND APPROWALA e minlmum. procedures are aproved by the maneeer of the

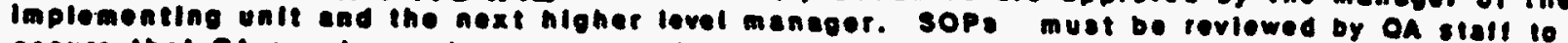

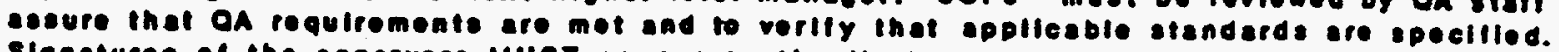

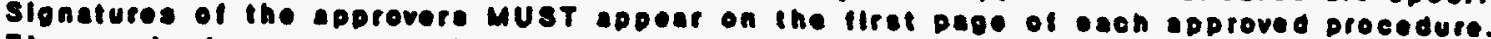

The required epprevers and the oA reviewer muet elen below.

Approved bys

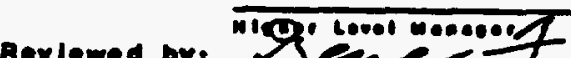

Rerlowed ori

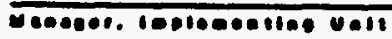

Dete

Dete

oate

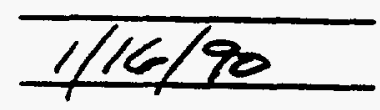

In the spees below Indleate edditional reviews (R) or sporovals (A). All reviewers and

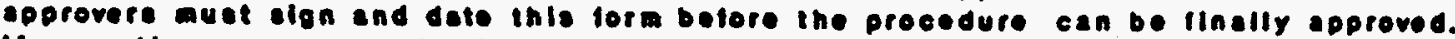
It more then one proesudre ls belno revlewed, attech list.

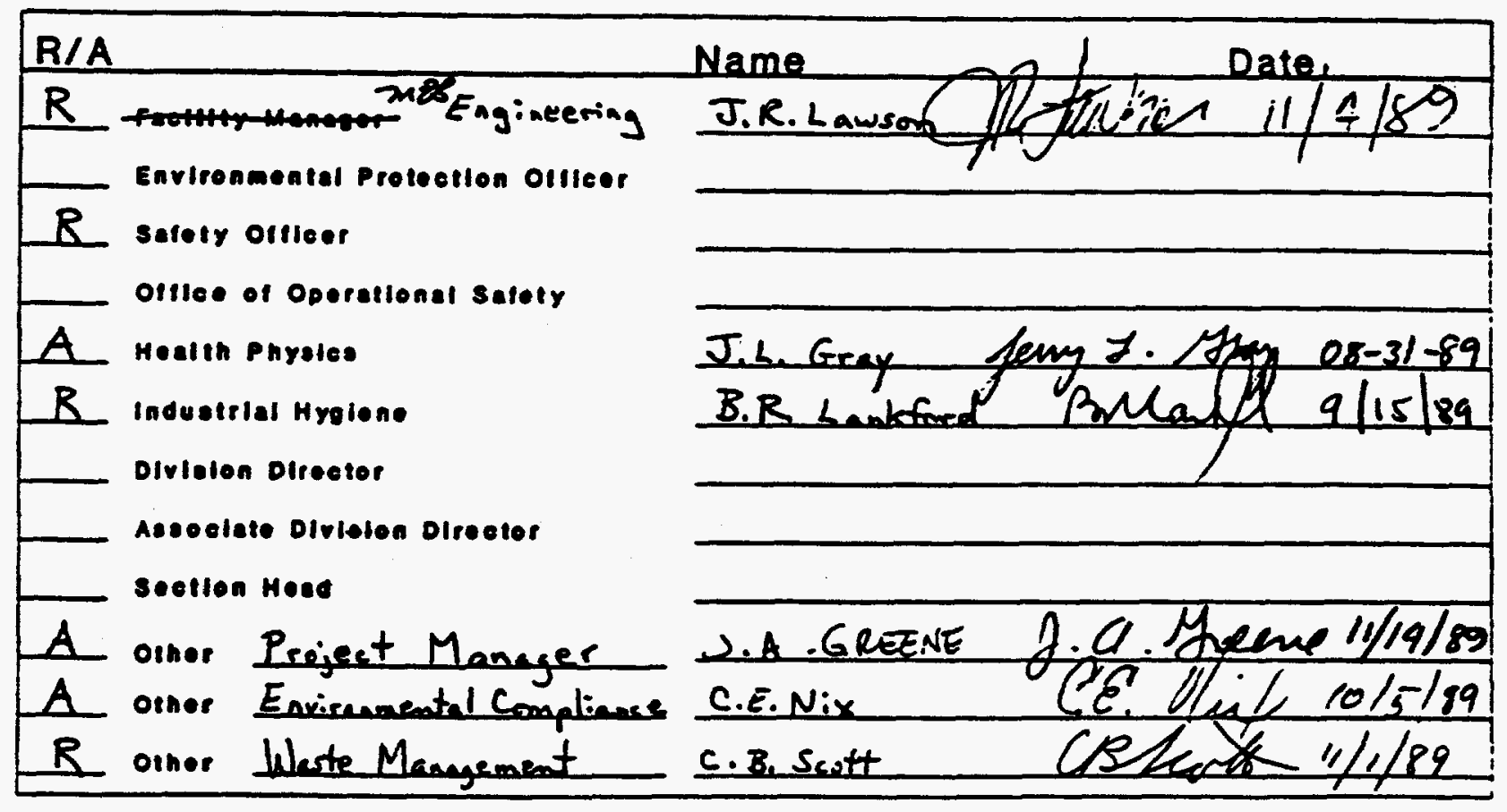

ts revisten of the sARiosh requiredr - YES XNO

sioneture

Next review dates: 2uycs.

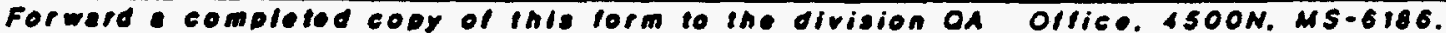




\section{OPERATING INSTRUCTIONS FOR HANDLING CUTTINGS AND WATER FROM \\ FROY WELL DRILLING AND DEVELOPMENT OF THE GROUNDWATER QUALITY MONITORING WELLS}

\subsection{PURPOSE}

The purpose of this document is to cite the steps that are followed to handle water and soil produced during the Installation and development of wells.

\subsection{SCOPE}

This document applies to well drilling and development assoclated with the Groundwater Quality Monitoring Wells Installation Program at Oak Ridge National Laboratory.

\subsection{REFERENCE}

Health, Safety, and Environmental Protection Procedures for Excavating Operations, ORNL/M-116/R1, Oak Ridge National Laboratory, March 3, 1988.

\subsection{DEFINITIONS}

Well Ratings. Ratings assigned during the excavation permit cycle by Radiation Protection (RP) and Industrial Hygiene (IH) to indicate the probability of encountering radioactive and chemical contamination, respectively. These ratings are based on historical information or from previous drilling or excavation activity. The ratings are marked on the excavation permits. (RP ratings on permits may sometimes be called "HP'" for "Health Physics." The two designations are interchangeable.) Protective measures required for the three categories are stated in Table 1, "Excavation-classification categories," in ORNL/M-116/RI. The categories for soil handling are stated in Appendix B, 'Radiological Soil Handling Criteria,"' in ORNL/M-116/RI.

RP Category 1. A rating assigned by RP which indicates that the probability of encountering radioactive contamination is low and that intermittent monitoring is required by $R P$.

If Category 1. A rating assigned by IH which indicates that the probability of encountering chenical contamination (i.e., organics) is low and that monitoring is not required by IH. An IH and/or Environmental Monitoring and Compliance (EM\&C) representative will be called in any time chemical or hazardous contamination is suspected.

RP Category 2. A rating assigned by RP which indicates that the probability of encountering radioactive contamination is moderate and that continuous monitoring is required. The RP representative will determine the necessary level of protective clothing to be worn.

IH Category 2. A rating assigned by IH which indicates that the probability of encountering chemical contamination is moderate and that respirators must be on-site and ready for use by the workers when 
indicated by the IH or RP representative on-site. Location will be checked periodically with an IH field instrument, such as a Photovac or Organic Vapor Organizer (OVA).

RP Category 3. A rating assigned by RP which indicates that there is a high probability of encountering radioactive contamination. Therefore, continuous monitoring by an RP representative is required, and protective clothing must be worn. In addition to the training listed above, workers must have successfully completed the Category 3 Driller Training course that is administered by Environmental and Health Protection Division (E\&HP) personnel.

IH Category 3. A rating assigned by IH which requires the workers to wear respirators as a minimum. Additional protection deemed appropriate by IH will be designated for each location. Continuous monitoring by IH personnel is required.

Training Reguirements. Training requirements for workers include the Basic Radiation Iraining administered by E\&HP personnel and the $40 \mathrm{~h}$ of training required by the superfund Amendment Reauthorization Act (SARA) through a company-approved course. There is an additional training course required for Category 3 drilling.

Alr rotary containment box. A box specially designed to contain the cuttings and water that are blown from the borehole during air rotary drilling. The box is equipped with a high-efficlency particulate air (HEPA) filter to prevent particles that possibly contain contaminants from being dispersed into the air. Air rotary drilling is generally used only for drilling into bedrock.

Auger pan. A metal catch pan with a hole cut in the middle. The pan surrounds the borehole and contains soil cuttings as they are augered up.

Proper On-Site Disposal. Disposal of noncontaminated soil and water produced from work on a well at a location near the well that is not openly visible to the public and has no risk of causing erosion or direct discharge into a stream. The construction engineer (CE) will indicate to the drillers which areas are acceptable for on-site disposal. The pH will have been checked and adjusted to the 5-to-9 range before releasing. This precise definition is intended wherever this term is used in this procedure.

Proper Contaminated Waste Disposal. Generally, radioactively contaminated soil will be packaged in drums and tagged by the RP representative for disposal by ORNL Waste Operations. However, Category-2-level soil may be used on site as backfill in remote areas when covered by $1 \mathrm{ft}$ of noncontaminated soil as stipulated in ORNL/M. $116 / R 1$. The $C E$ will specify to the drillers when a well location has been approved by EM\&C for on-site disposal of contaminated soil. This definition is intended wherever this term is used in this procedure. 
Temporary Drilling Equipment Cleaning Facility. An outdoor area located in Melton valley for steam cleaning of drill rigs and associated equipment, referred to as the steam cleaning area.

Containment Box Holding PIt. A lined pit at the Temporary Drilling Equipment Cleaning Facility. The contents of the pit will be sampled and tested for gross alpha, gross beta, pH, and tritium*, before being released through a silt fence. Contents that have a potential for containing hazardous materials (i.e., IH Category 2 and 3 locations) will have been checked with an IH field instrument before being released into the pit.)

Steam Cleaning Pits. Two lined pits at the Temporary Drilling Equipment Cleaning Facility that collect runoff from the stean cleaning operations. The contents of the pits will be sampled and tested for gross alpha, gross beta, pH, and tritium*, before being released through a silt fence. Contents that have a potential for containing hazardous materlals (i.e., IH Category 2 and 3 locations) will have been checked with an IH field instrument before being released into the pit.)

\subsection{RESPONSIBILITIES}

5.1 Radiation Protection Personnel monitor and determine the presence of detectable radioactive contamination in drill cuttings during well-drilling activities. They provide guidance to ensure that exposures to the workers, public, and environment are kept as low as reasonably achievable. They also provide radiation monitoring during the precursory cleaning by the drillers.

5.2 Well-Drilling Personnel perform well drilling and completion activities. They package soil and water in appropriate containers and transport it, if necessary; perform precursory cleaning of low-level contaminated equipment; and perform cleaning of equipment between the drilling of each well.

5.3 EDGe Hydrogeologists observe all crucial well installation activities and record data for all boreholes drilled. They do a visual inspection of the cuttings produced during augering and note any unusual occurrences and obvious deleterious material encountered during the drilling process. They check the cuttings and water with a Photovac or OVA or similar instrument and check pH of water when necessary.

5.4 Construction Engineer serves as the field contact and provides guidance to the drillers during field activities.

\subsection{PROCEDURE}

\subsection{EXPLANATION OF THE WELL RATING SYSTEM}

Each well is assigned a rating by RP and IH before drilling begins. Because additional information is gained during drilling. 
well ratings may be changed by RP and IH as the work progresses. A lower RP Category rating will be changed to a Category 3 rating upon encountering radioactive contamination within the Category 3 range defined in ORNL/M-116/RI. Likewise, an IH Category 3 may result if chemical contamination is detected in a well with a lower rating. The RP and/or IH representative on site will notify the on-site personnel when conditions warrant a rating change. Any additional actions or modifications in protective clothing required by the rating change will be executed at that time. The change will be documented imediately by the on-site hydrogeologist in the well data package and as soon as possible by the RP and/or IH representative by a signed written statement stating the well number, the old and new ratings, and the rationale supporting the change. The statement will be sent by the RP and/or IH representative to the Construction Engineer (CE) for filing with the original excavation permit. A copy will be sent to the RAP Well Installation Manager by the CE.

A well category also may be changed from a higher rating to a lower rating. For example, if no contamination is encountered while drilling a Category 2 or 3 well, it may be changed to a lower rating after drilling to a certain depth or for development purposes, depending on the history of the area. The documentation procedure stated above for an increase in rating must also be followed for a decrease in rating.

\subsection{CATEGORY I WELLS (RP OR IH)}

\subsubsection{Category 1 Drflling}

\subsubsection{Category 1 Auger Cuttings}

a. Auger cuttings will be collected in a catch pan.

b. An RP representative will scan the cuttings intermittently to check for radioactive contamination. Cuttings will be inspected for any unusual discoloration or odor by the hydrogeologist.

c. If there is no contamination detected, proper on-site disposal or disposal at the steam cleaning area will be done.

\subsubsection{Category 1 Air Rotary Drilling}

a. Cuttings will be collected in a containment box.

b. When the containment box is full, one of the following will be done to empty cuttings and/or decant water frow the containment box:

$$
\text { proper on-site disposal. }
$$


(2) disposal at the containment box holding pit..

6.2.2 Category 1 Well Development

6.2.2.1 Water removed from the well will be contained in drums.

6.2.2.2 The $\mathrm{pH}$ of the water will be measured and will be adjusted to be between 5 and 9 by the CE if it is above or below that range.

6.2.2.3 Drums of water will be discarded by proper on-site disposal or disposal at the steam cleaning area will be done.

\subsection{CATEGORY 2 WELIS (RP AND IH)}

\subsubsection{Category 2 Drilling}

\subsubsection{Category 2 Auger Cutrings}

a. Auger cuttings will be collected in a catch pan.

b. An RP representative will scan the cuttings continuously to check for radioactive contamination. Cuttings will be inspected for any unusual discoloration or odor and tested with a Photovac or OVA by the hydrogeologist for presence of RCRA materials.

c. If there is no contamination detected, proper on-site disposal or disposal at the steam cleaning area will be done.

d. Cuttings will be contained in drums if contamination is detected. Proper disposal will be arranged by Martin Marietta Energy Systems through Waste Operations.

\subsubsection{Category 2 Air Rotary Drilling}

a. Rock cuttings and drill water will be collected in a containment box.

b. When the concainment box becomes full, the RP representative will perform a wet towel smear to detect the presence of radioactive contamination. An inspection for unusual discoloration or odor and tests with an OVA will be conducted for the presence of RCRA materials by the hydrogeologist. 
c. If no contamination is detected, one of the following will be done to empty cuttings and/or decant water from the concainment box:

(1) proper on-site disposal.

(2) disposal at the containment box holding pit.

d. If contamination is detected by the tests, arrangements will be made by Martin Marietta Energy Systems through Waste Operations to properly dispose of the water. Further laboratory testing of the box contents may be done.

\subsubsection{Category 2 Development}

6.3.2.1 Water removed from the well will be contained in drums.

6.3.2.2 When the drums are ready to be emptied, the RP representative will perform a wet towel smear to detect the presence of radioactive contamination. An inspection for unusual discoloration or odor and tests with an OVA will be conducted for presence of RCRA materials by the hydrogeologist. The $\mathrm{pH}$ will be adjusted if necessary.

6.3.2.3 If no contamination is detected, the water will be discarded by proper on-site disposal or disposal at the steam cleaning area will be done.

6.3.2.4 If contamination is detected by the tests, arrangements will be made by Martin Marietta Energy Systems to properly dispose of the water. Further laboratory testing may be done.

6.4 CATEGORY 3 WELIS (RP AND IH)

\subsubsection{Category 3 Drilling}

\subsubsection{Category 3 Augering}

a. When a well is classifled as an RP Category 3 or an IH Category 3, continuous monitoring will be required by RP and IH. Wearing of respirators will be required. Cuttings will be inspected for any unusual discoloration or odor. Tests for chemical contamination (i.e., organics) will be performed with IH field instruments by an IH representative for IH Category 3 wells. Specially trained personnel will be required to do the drilling. 
b. If no contamination is detected by $R P$ or IH while augering through soil to bedrock, a rating may be changed by RP or IH to a Caregory 2 depending on the depth, the type of contamination expected, and the history of the area.

c. If contamination is detected during augering, cuttings will be drummed. Proper disposal of all cutrings and water will be arranged by Martin Marietta Energy Systems.

\subsubsection{Category 3 Alr Rotary Drilling}

a. Rock cuttings and drill water will be collected in a containment box.

b. When the containment box becomes filled with water and/or cuttings, a sample will be collected by EM\&C and will be tested by the Analytical Chemistry Division for gross alpha, gross beta, tritium*, for an RP Category 3. If it is an IH Category 3 , the IH representative on-site will determine which (if any) laboratory testing is necessary for chemical contaminants.

c. Proper disposition of the containment box contents will be decided by consensus of E\&HP, the IH or RP representative, EMAC, and the CE, based on the results from Analytical Chemistry Division of the above tests.

\subsubsection{Category 3 Development}

6.4.2.1 Water pumped from Category 3 wells will be contained in drums. Samples will be collected by EM\&C and will be tested by Analytical Chemistry Division for gross alpha, gross beta, tritium,, and pH. It will be tested with IH field instruments by IH representatives for the presence of RCRA materials.

6.4.2.2 A decision based on the test results will be made between E\&HP and Engineering whether to continue development.

\subsection{BOREHOLE CLEANING}

When sludge and water have accumulated in the bottoms of boreholes drilled in soil, the boreholes must be cleaned out prior to setting casings. A decision based on the location of the borehole and its rating will be made between the RP and/or IH representatives whether the sludge and water from the borehole must be contained in a drum. Water and sludge from a Category 2 well will be drummed, and a wet towel smear will be done by RP to 
8

determine proper disposal of the drum contents. Laboratory testing of the drum contents for gross alpha, gross beta, tritium*, and $\mathrm{PH}$ will be done if recommended by the RP or IH representative. Water and sludge removed from an RP Category 3 well will be drummed, and laboratory testing will be done for gross alpha, gross beta, tritium*, and PH. EMEC will be consulted to determine proper disposal based on the test results. Further laboratory testing to determine actual contaminants will be done if recommended by EM\&C.

- Testing for tritiun will be done for wells located in oreas where tritiun contemination is sumpected. This decision will be made between RP and EMRC. 
n
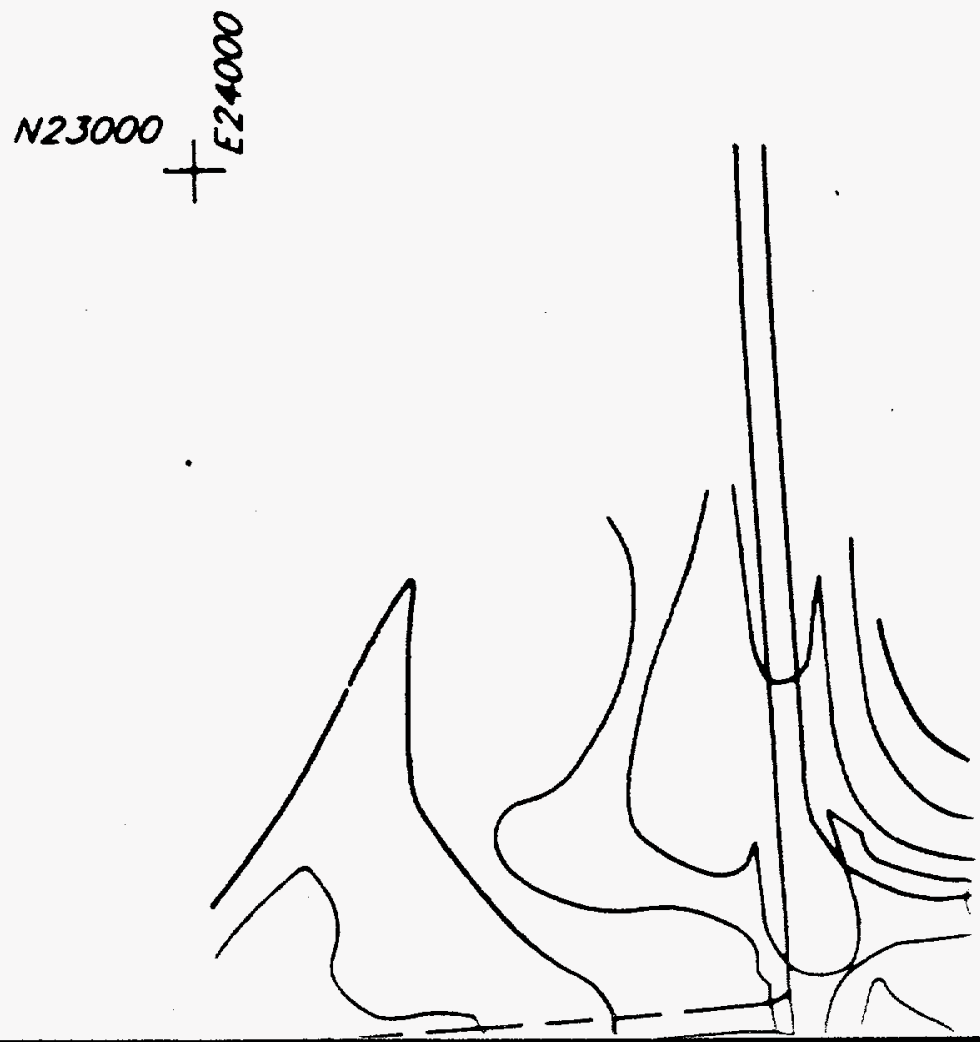

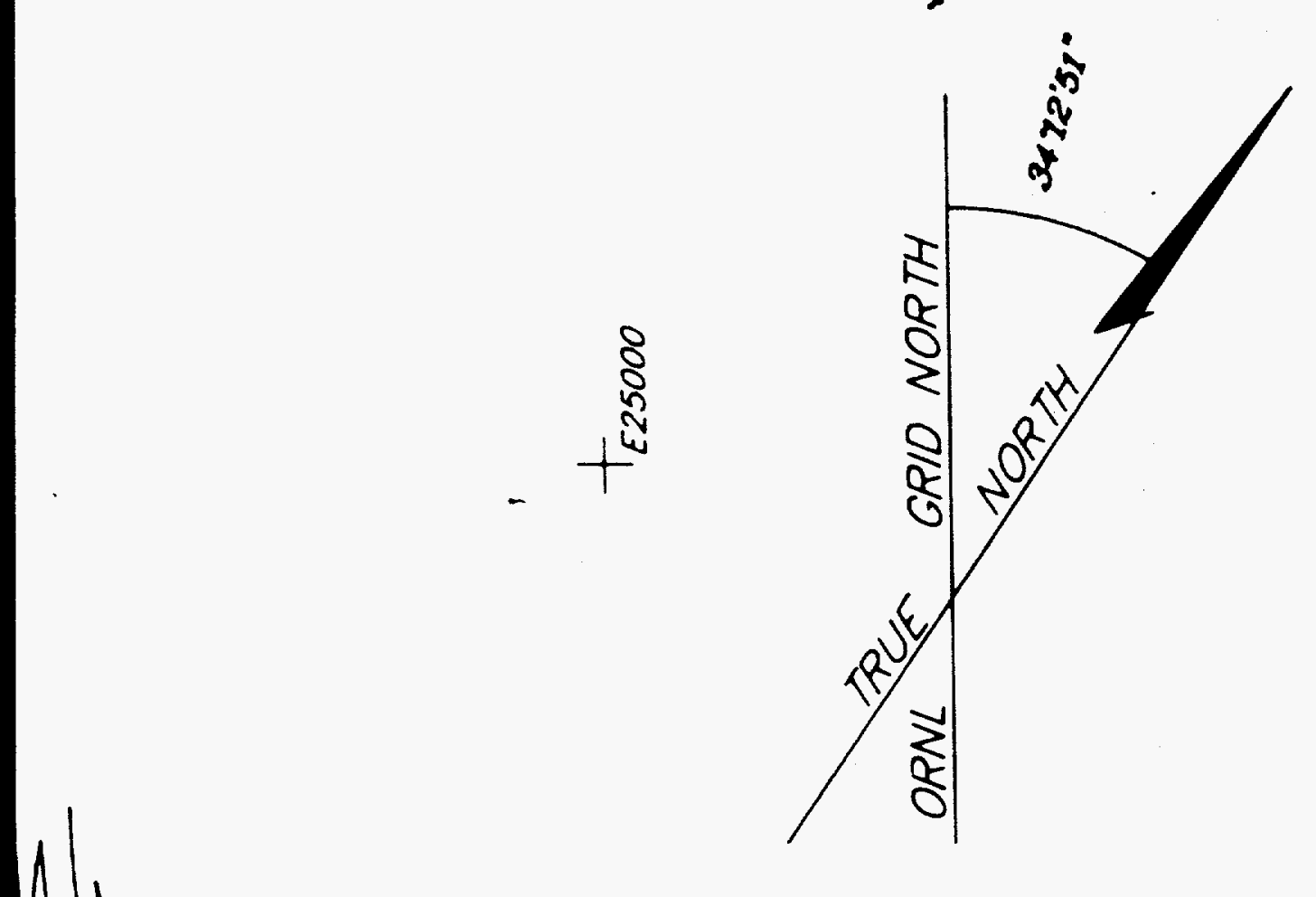


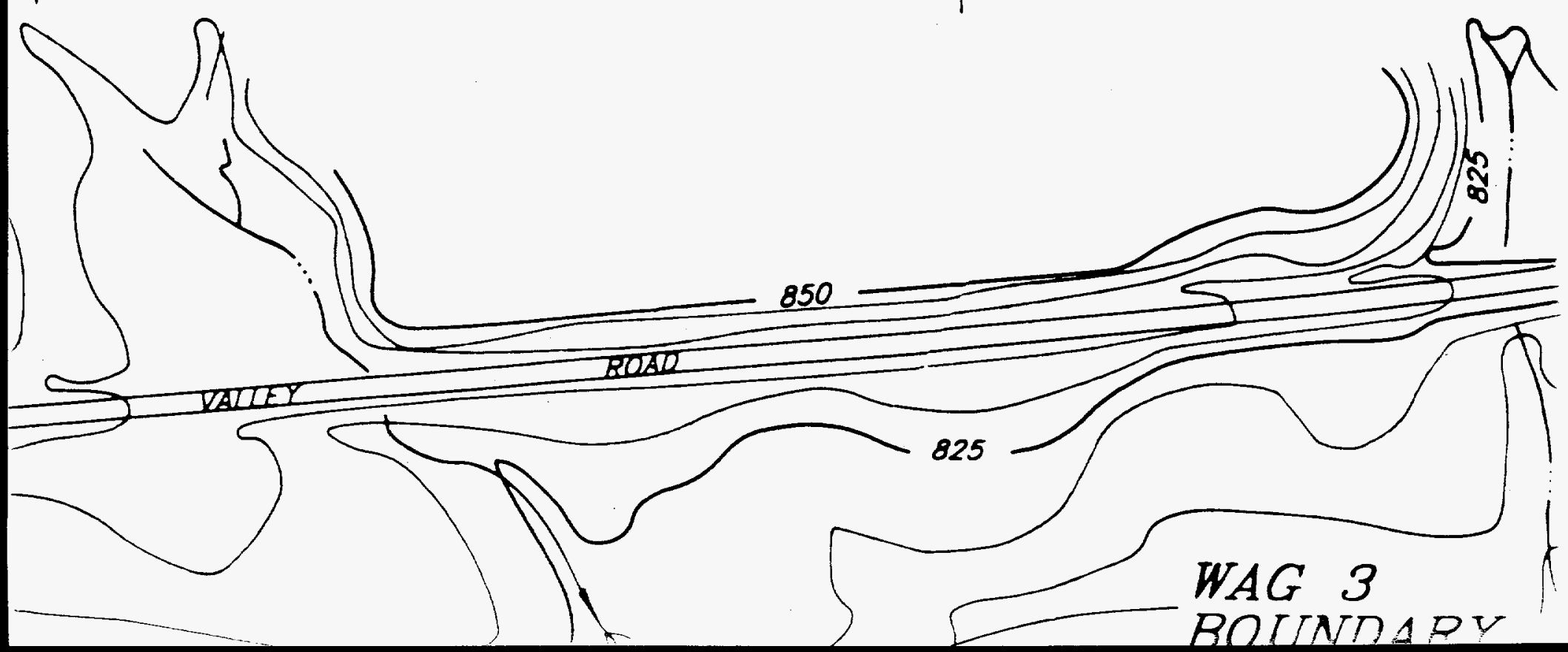




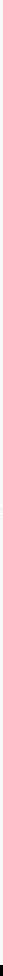




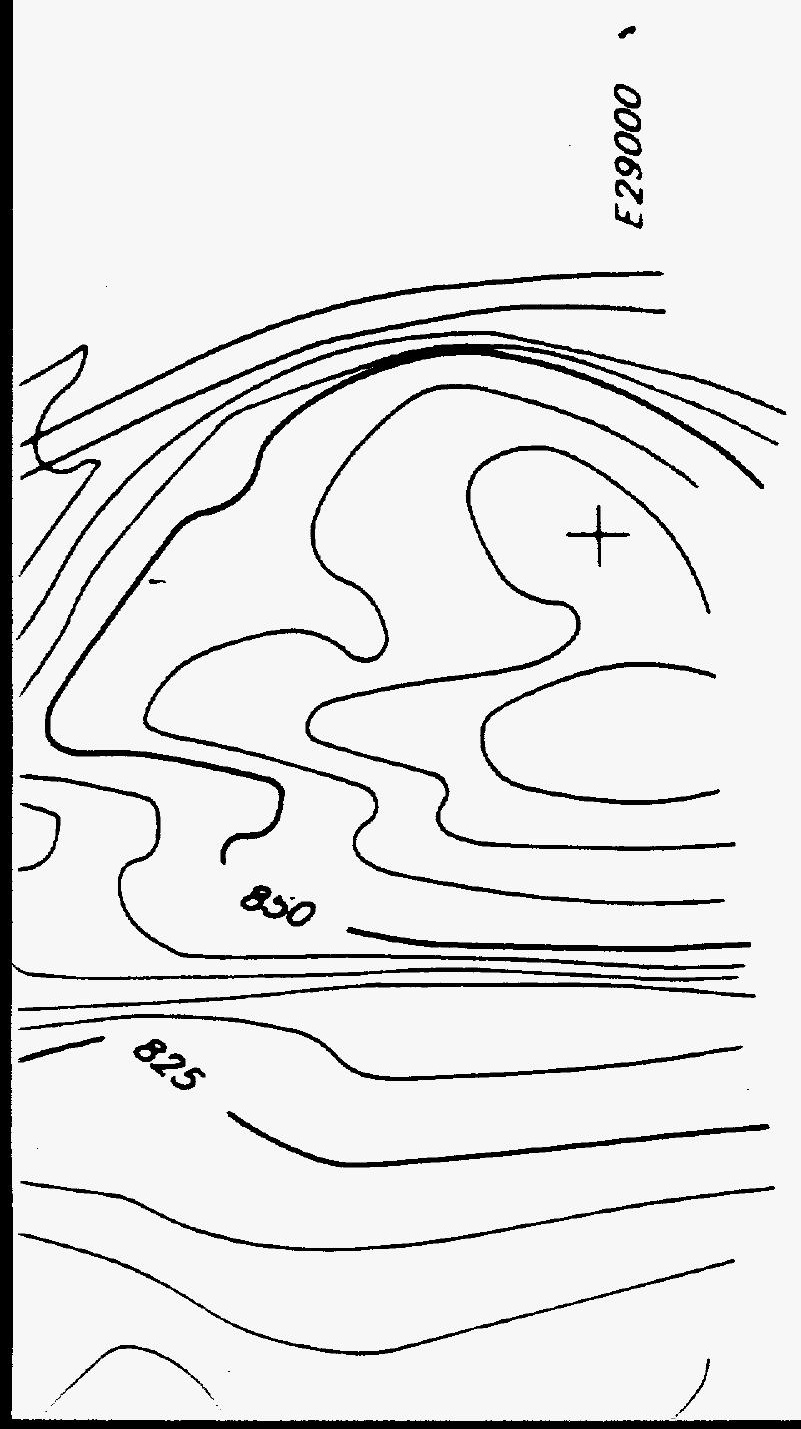


H

G 


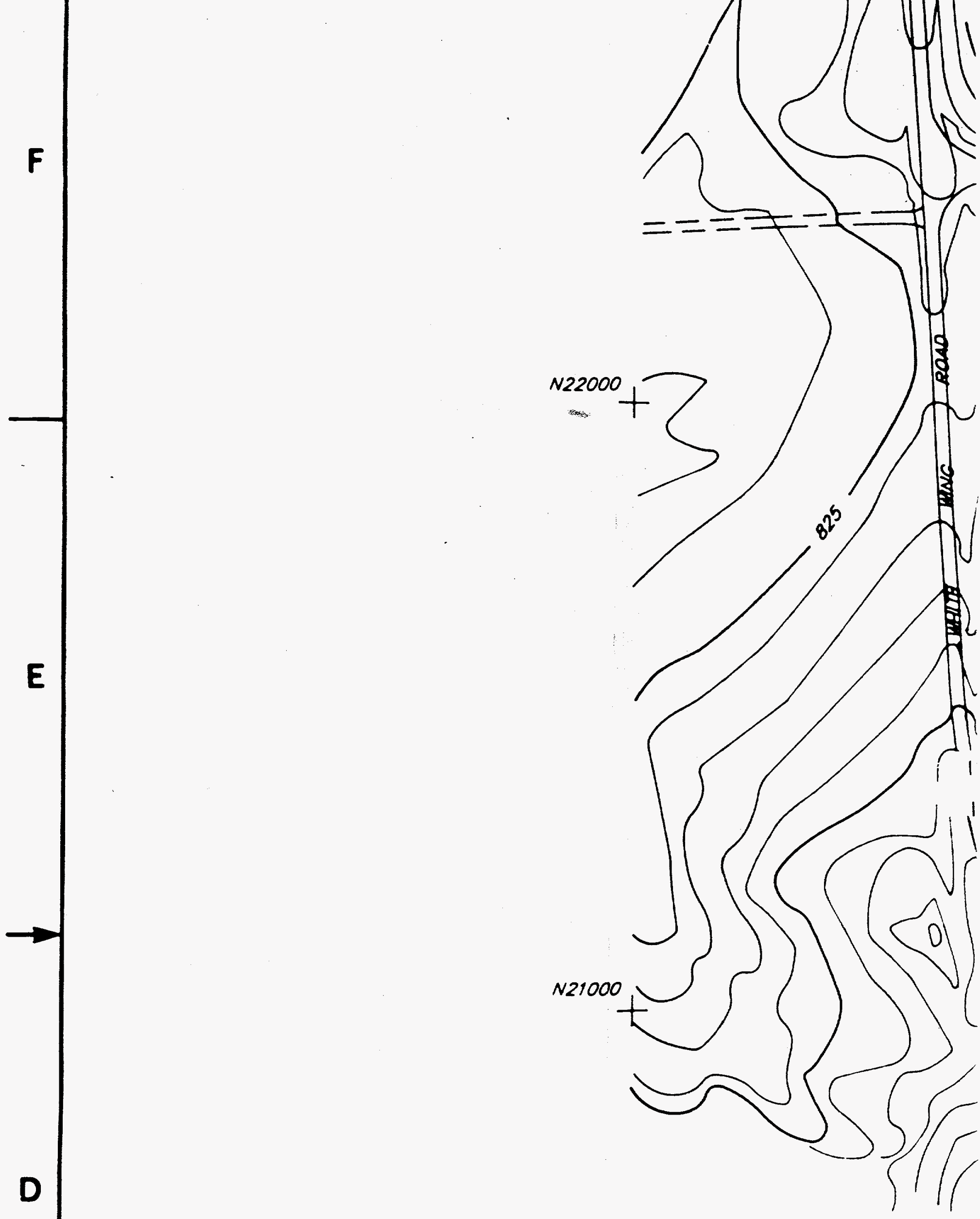




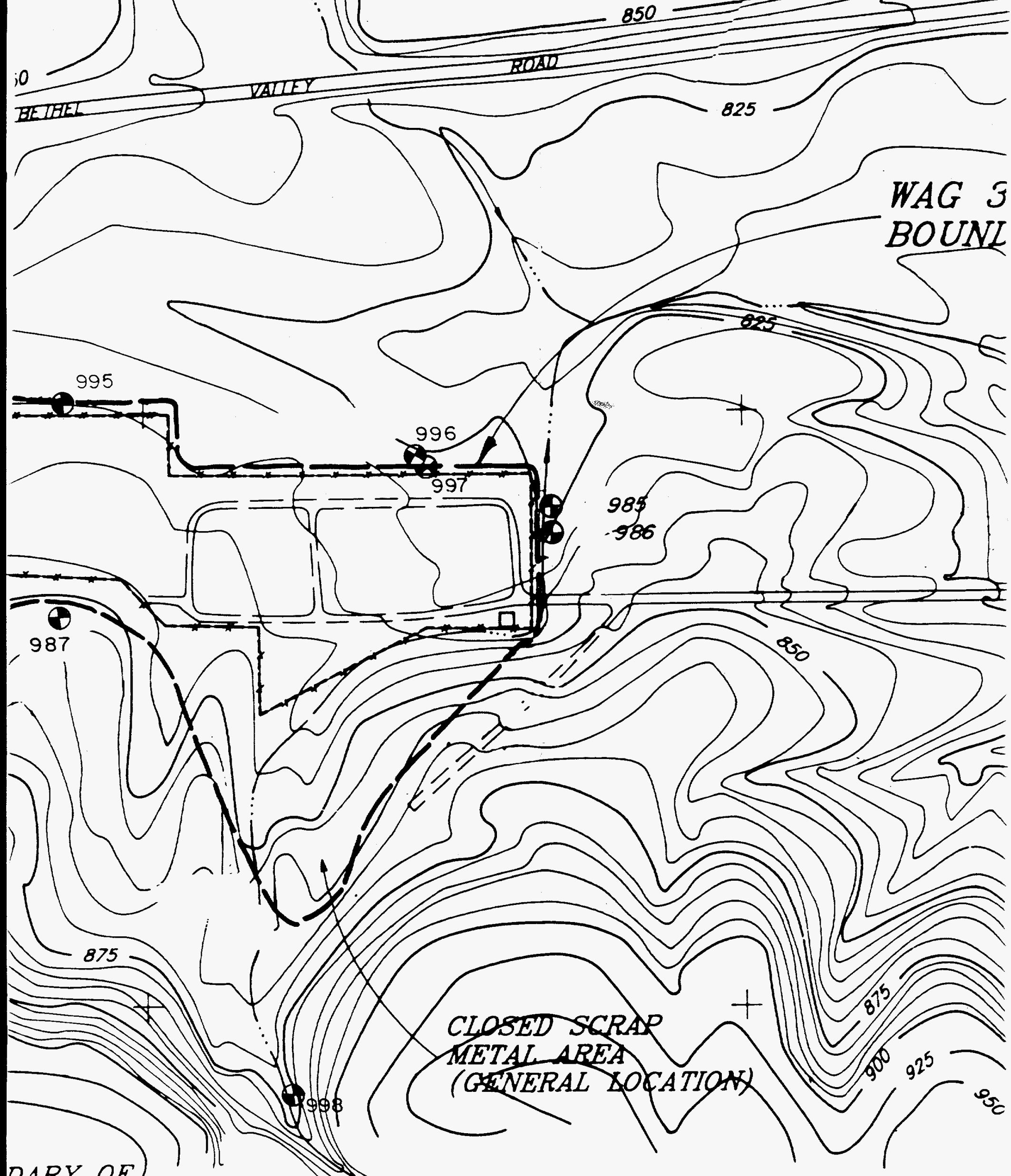

$D A R Y O F$
DILL 


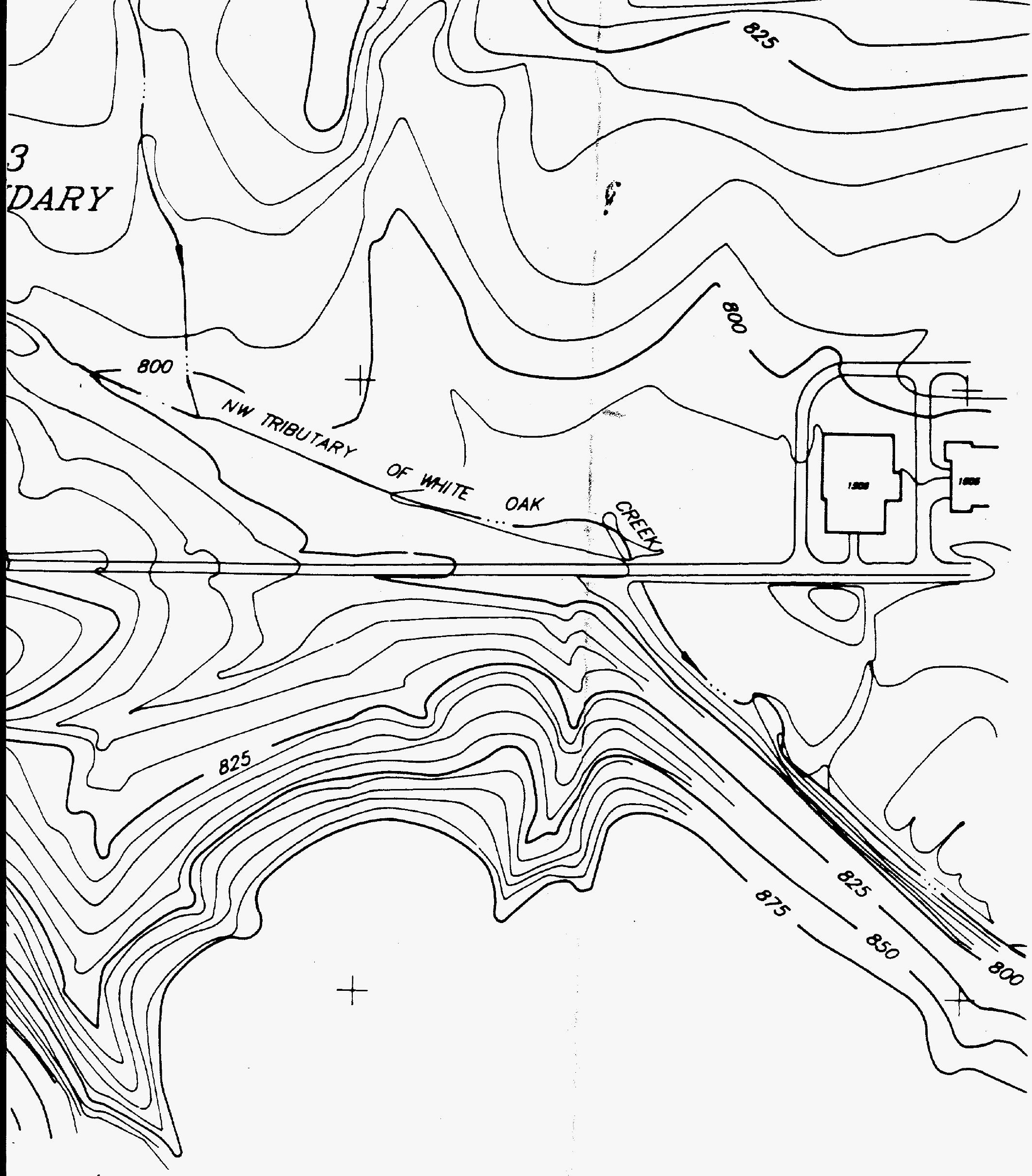




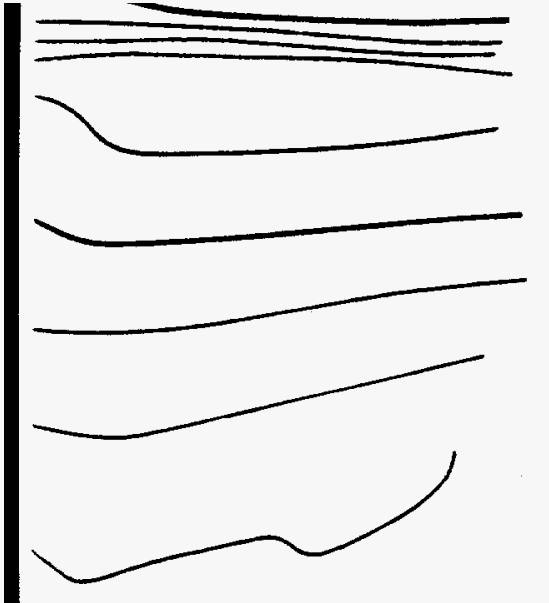

$\rightarrow$

\section{WAG 3 GROUNOWATER QUALITY MONITOR: WELLS AS-BUILT COORDINATES}

WELL
985
986
987
988
990
991
992
993
994
995
996
997
998
1247
1248

NORTHING

$21,833.81$

$21,813.16$

$21,650.14$

$21,075.73$

$21,657.34$

$21,736.64$

$21,737.04$

$21,834.35$

$22,011.41$

$21,920.17$

$21,011.04$

$20,984.59$

$21,357.58$

$21,366.92$
$21,895.03$

$\underline{E_{i}}$
26
26
25
25
24
25
25
25
25
25
26
26
26
24
24

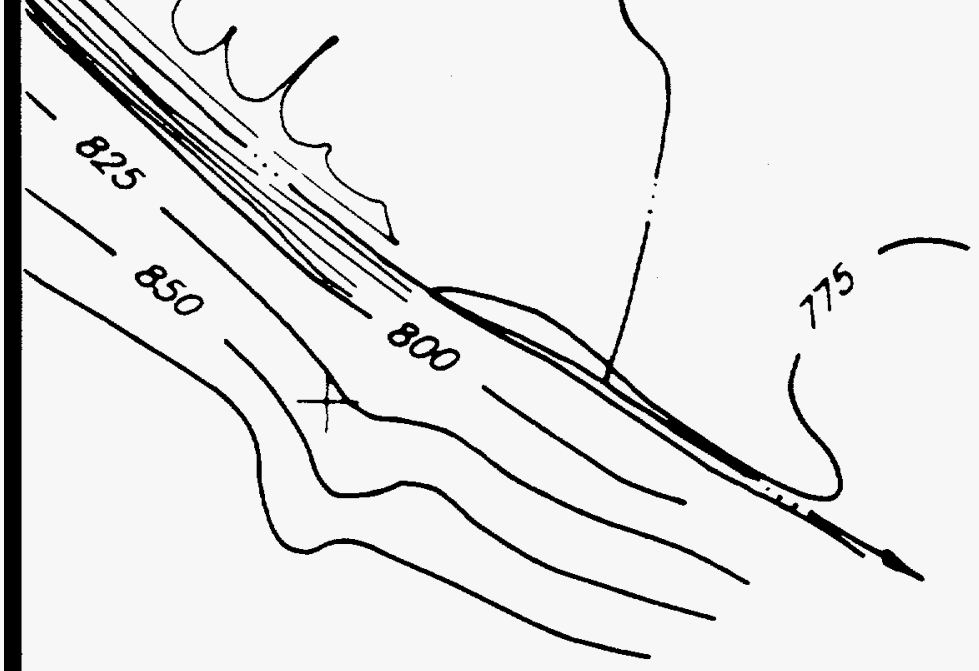


R QUALITY MONITORING

T COOROINATES

RTHIING

833.81

813.16

650.14

075.73

657.34

736.64

737.04

8884.35

895.03

af 1.41

920.17

911.04

984.59

357.58

366.92
EASTING

$26,675.61$

$26,674.67$

$25,857.89$

$25,471.29$

$24,723.62$

$25,051.49$

25.069 .69

$25,619.08$

$25,639.92$

$25,867.56$

$26,458.18$

$26,467.50$

$26,235.94$

$24,659.55$

$24,654.08$ 


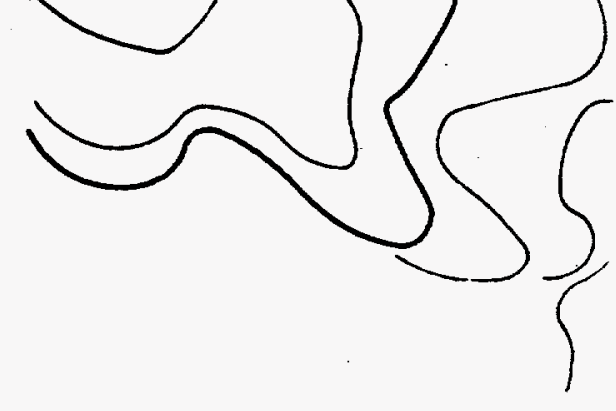

C

B 


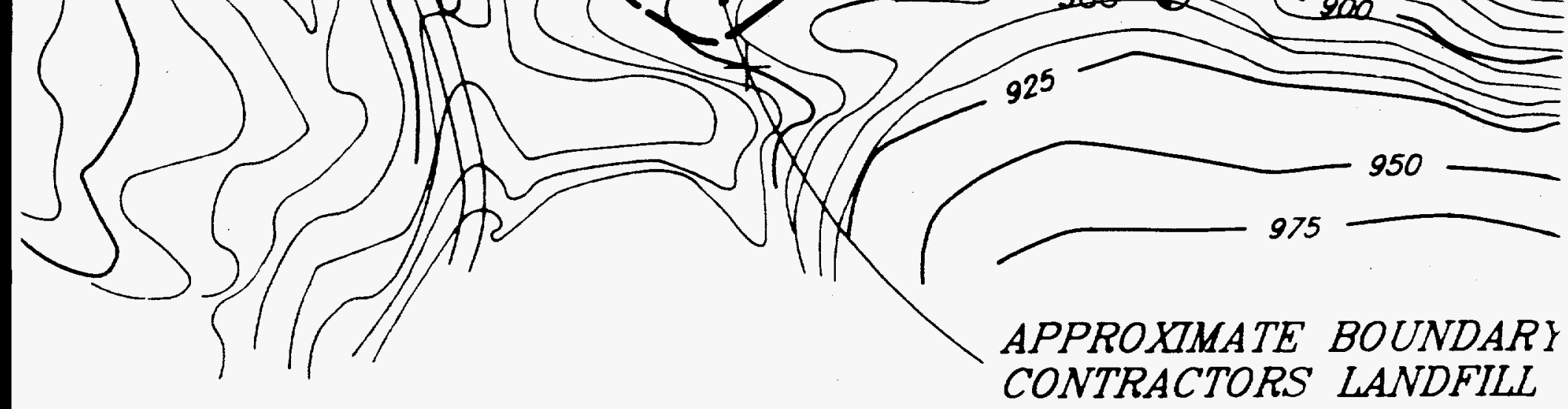



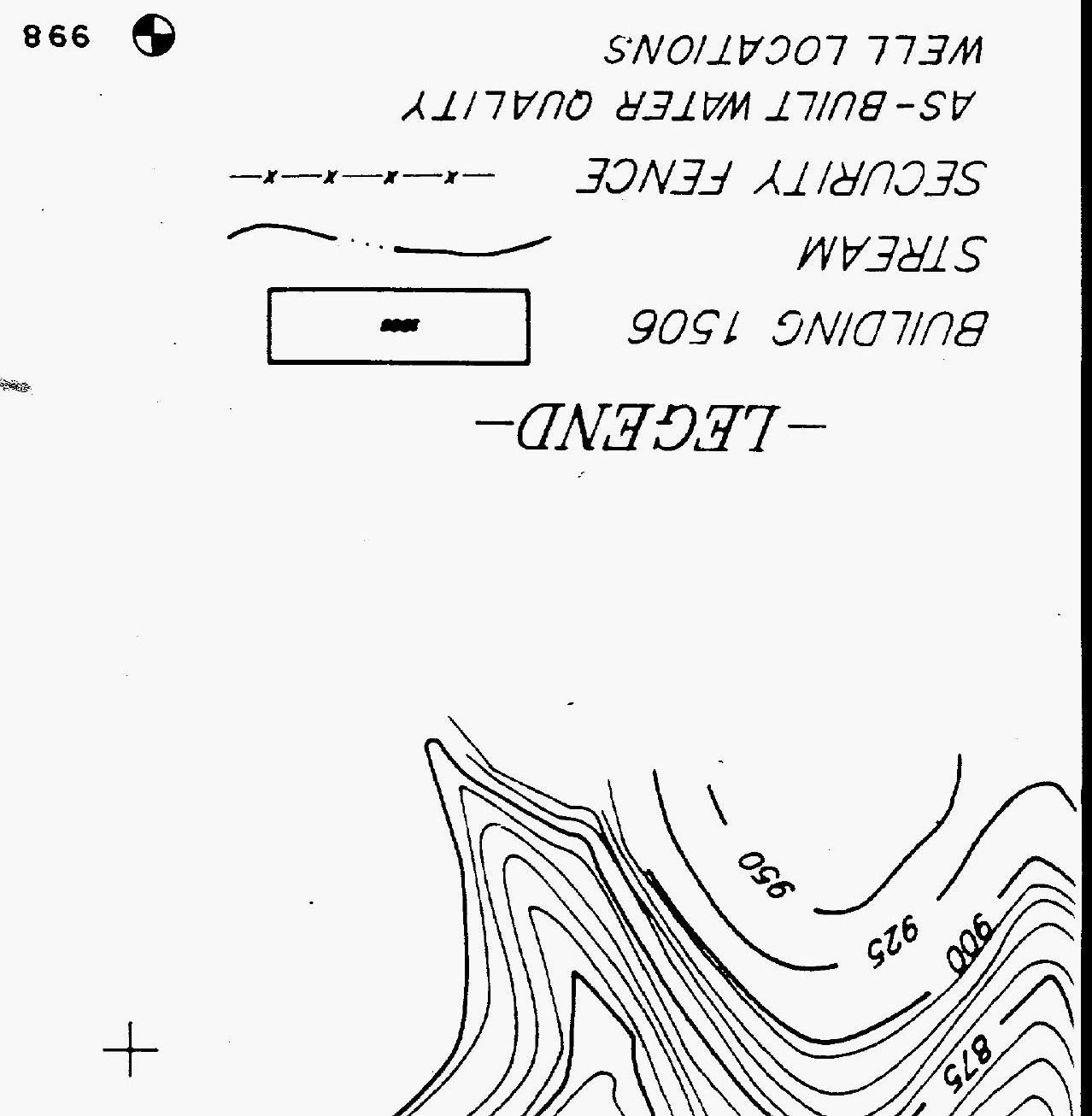


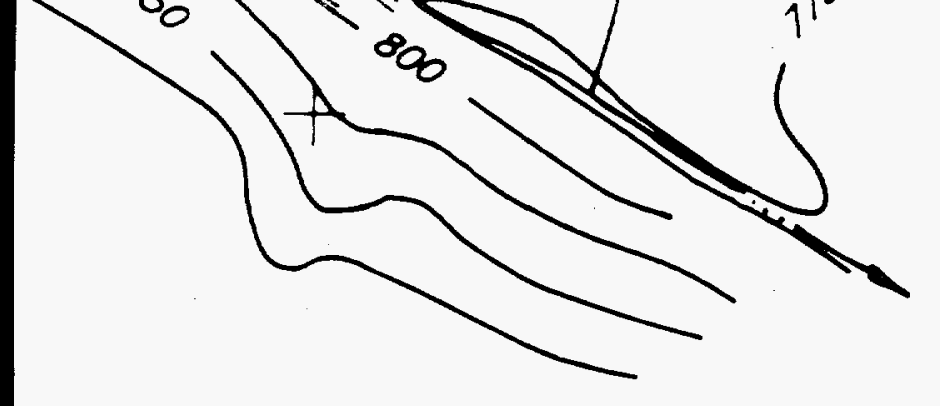




\begin{tabular}{l|l|l}
$\frac{1}{3 \mathrm{E} 20004 \overline{\mathrm{AOB2}}}-\mathrm{J}$ & 0 & 0
\end{tabular}




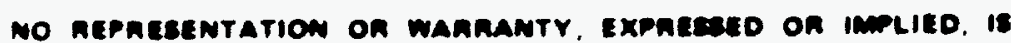

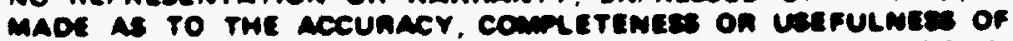

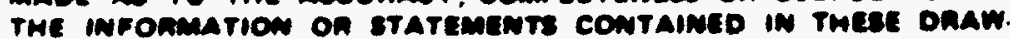
INOS. On TMAT TME UAE ON DUSCLOUUAE OF ANY INFONAMATION. amanatus, metmoo on mocese onclosed in tmese onawines may mot imfaimes paivate niowts of otmens. Mo liadility is

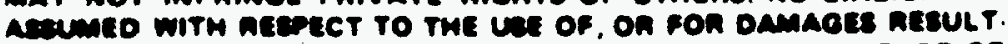

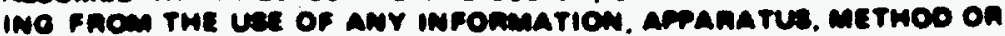

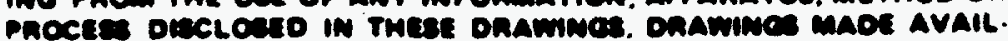

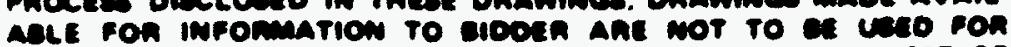

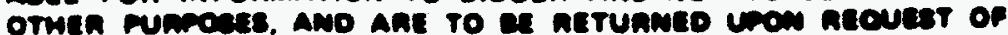
twe fonmanowne courancton 


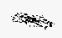

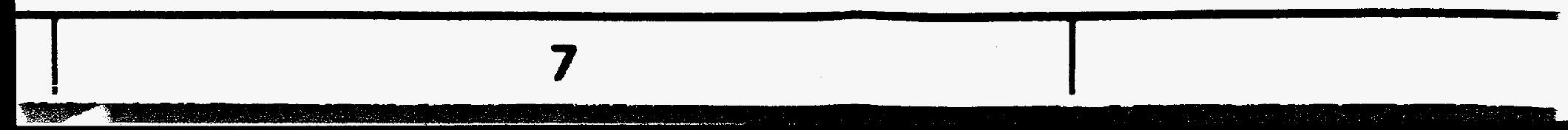




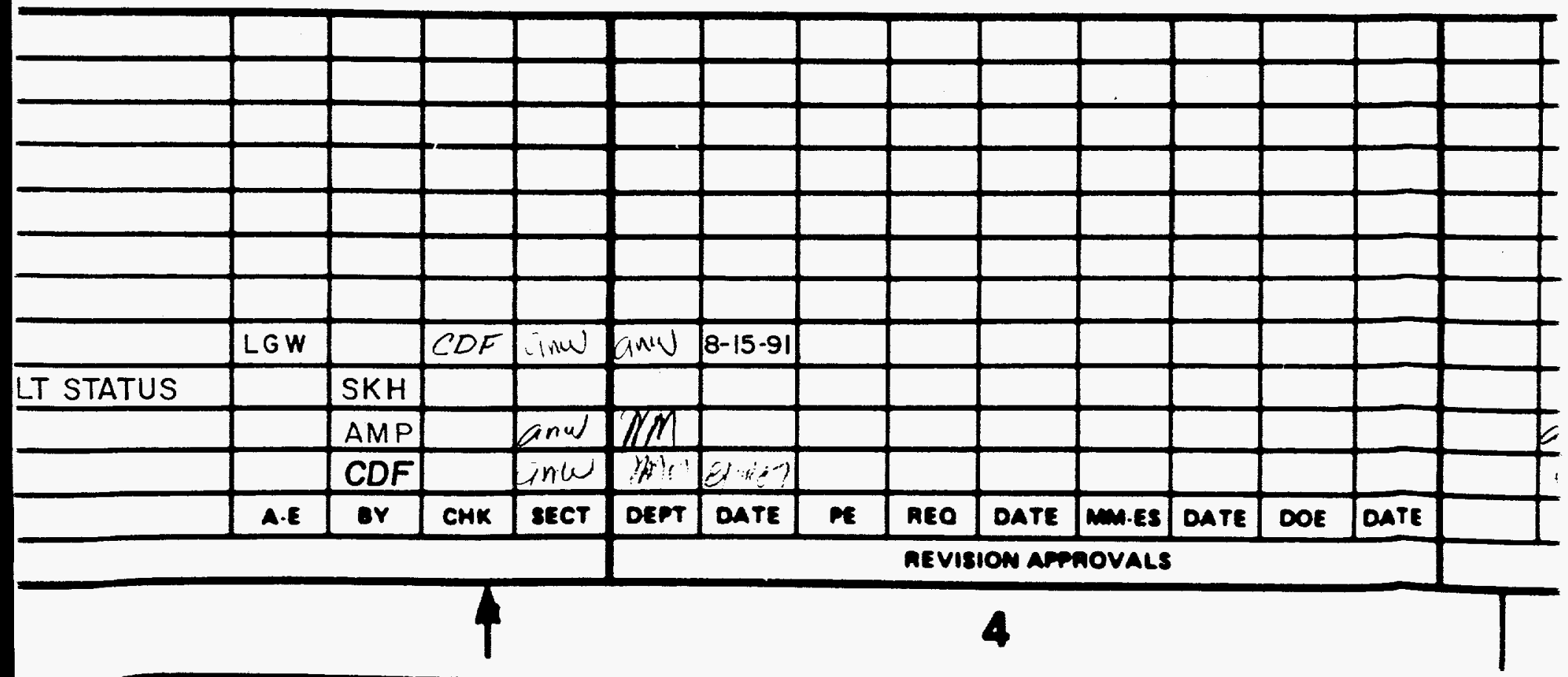




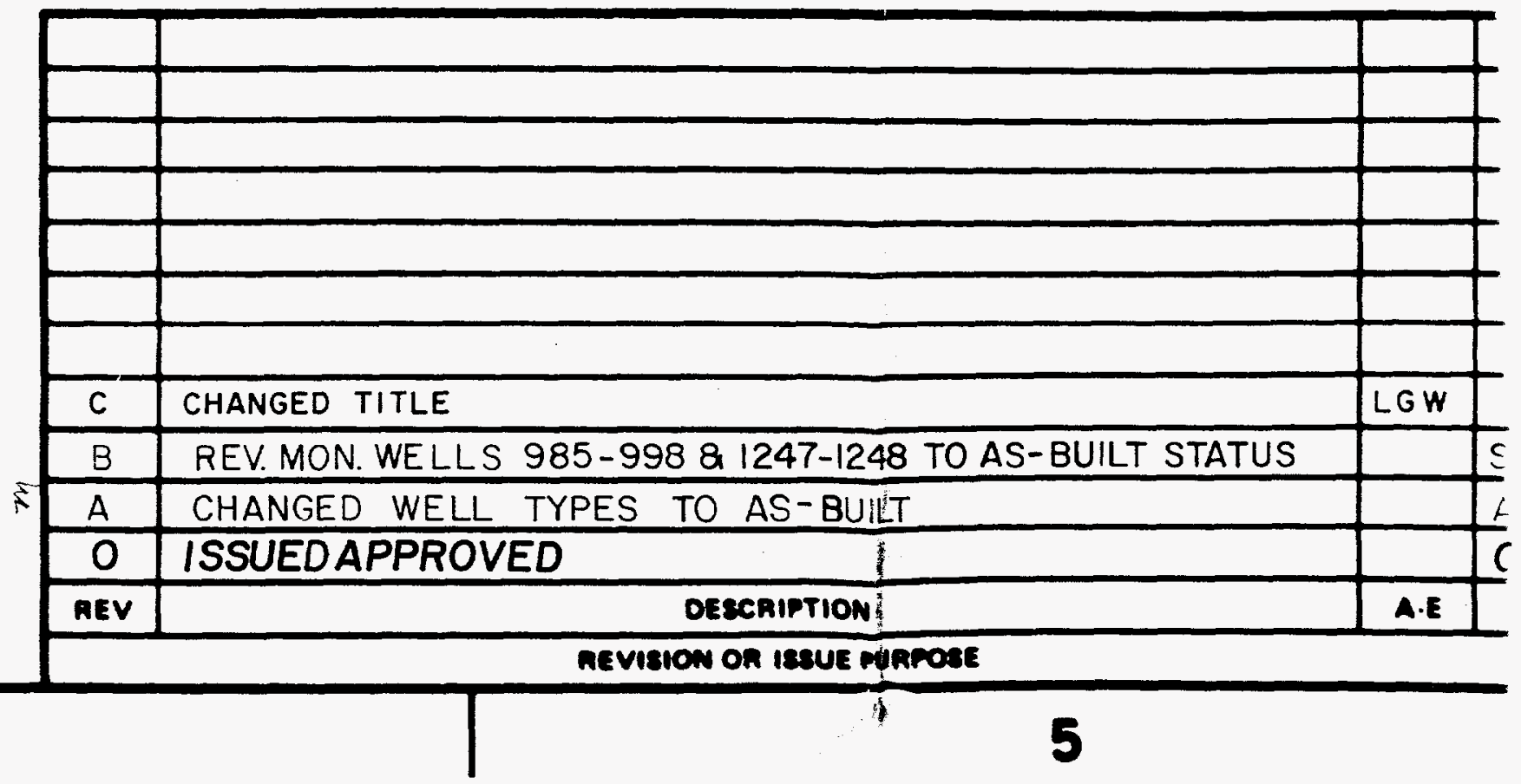




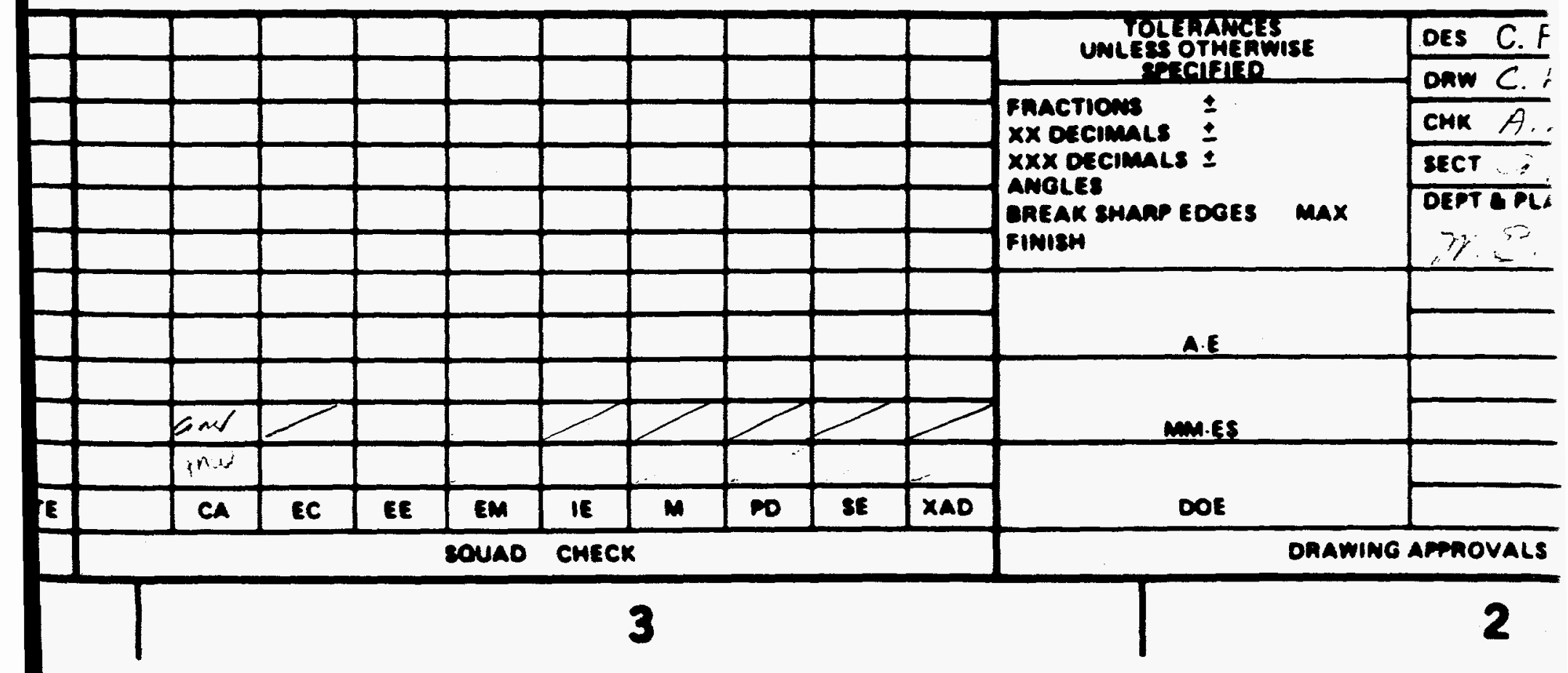




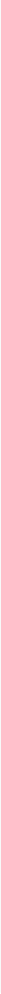




\section{DISTRIBUTION}

1. F. P. Baxter

2. H. L. Boston

3. W. D. Brickeen

4. T. A. Early

5. M. L. Ebers

6. R. H. Ketelle

7-9. D. M. Matteo

10. J. A. Mortimore

11-12. P. T. Owen

13. P. A. Schrandt

14. M. M. Stevens

15. P. S. Wood

16-18. ORNL ER Document Management Center

19. ORNL Patent Section

20-22. Central ER Document Management Center

23. Laboratory Records Department

24. Central Research Library

25. Office of Assistant Manager for Energy Research and Development, DOE Oak Ridge Operations Office, P.O. Box 2001, Oak Ridge, TN 37831-8600

26-27. Office of Scientific and Technical Information, P.O. Box 62, Oak Ridge, TN 37831 